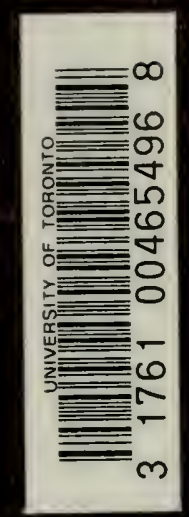

a 

Digitized by the Internet Archive in 2008 with funding from Microsoft Corporation 



\section{NORMAL HISTOLOGY.}

$\mathrm{BY}$

EDWARD K. DUNHAM, Pr. B., M.D.,

PROFESSOR OF GENERAL PATHOLOGY, BACTERIOLOGY, AND HYGIENE IN THE UNI LRSITY AND BELLEVUE HOSP TAL MEDICAL COLLEgE, NEW YORK.

THIRD EDITION, REVISED AND ENLARCELD.

ILLUSTRATED WITH 260 ENGRAVINGS.

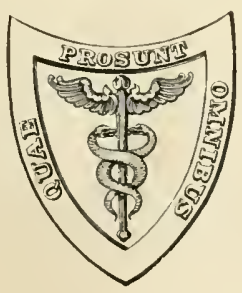

LEA BROTHERS \& CO., NEW YORK AND PHILADELPHIA.

1904 . 
Entered according to Act of Congress in the year 1904, by LEA BROTHERS \& CO.,

in the Office of the Librarian of Congress, at Washington. All rights reserved.

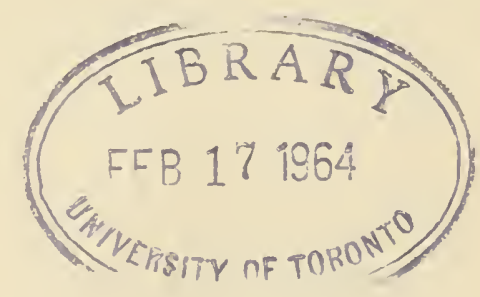

\section{9}

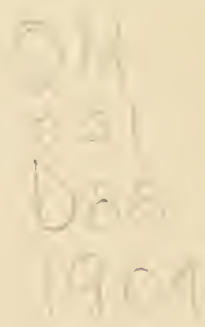




\section{PREFACE TO THE THIRD EDITION.}

THE general plan and scope of this outline of histology are the result of experience in teaching this subject to students of medicine under conditions which require economy of time. In order to accomplish the greatest amount of instruetion under these circumstances it seemed necessary to present, early in the course, certain generalizations which might be kept eonstantly in mind and assist the memory in retaining facts by showing their logical eorrelation. The broad ideas of almost universal applicability which were chosen for this purpose were: first, the eonception of the eell as the aetive constituent of tissues; second, the general rule that the elementary tissues are composed of cells and intercellular substances, and that their differences depend upon the proportions or charaeters of those constituents; third, that the structural details of the different tissues are intimately correlated to their usefulness-i.e., that function and strueture are mutually dependent upon each other, being but two aspeets of a single device or arrangement; and, fourth, that the ability of tissues to perform active funetions is, in the main, roughly proportional to the number or size of the cells entering into their structure.

The author believes that his experience has shown that the early introduction of these fundamental ideas has been a distinet aid to the student; and it is his belief that sueh would also be the ease no matter to what limits the course of instruction in this subject might be extended.

In the elaboration of these ideas the author has been in the hahit of arbitrarily dividing the activities of the cells of the body into four theoretical groups: the reproductive activities, leading to the production of new cells; the formative activities, through which the structural modifications resulting in the formation of different varieties of tissue were brought about ; the mutritire activities, maintaining the integrity of the ti-sues already formed; and the functional 
activitics, through which the tissues serve the whole organism of which they are constituent parts.

Assuming that histologry should invariably be tanght largely by practical work and experienee in the laboratory, and reeognizing the fact that it must have a place in the beginning of a medical 'urriculum when the student's technical facility is least developed, the writer believes that the best way to teach the subject is by means of demonstrations at which the students have ample opportunities to beeome familiar with the structural details of the best attainable specimens so prepared as to reveal the presence and arrangement of the tissue-clements. In addition to such a course of demonstrations he should receive practical instruction in histoIognical technique, during which he may become versed in the methods employed in the preparation of the specimens he uses in the demonstration course. This work may be so arranged as to permit his preparing a collection of specimens for himself.

I'ith such related courses of instruction in mind, the writer has added a section on Histological Technique to the present volume. In this part of the book he has endeavored to make clear those varions methods of preparing tissnes for microcopical study which he has found to yield excellent results, not only in his own hands, but also when employed by those who have had no previons experience in such work. The more complicated methods, requiring such experience, have been omitted.

The student occa-ionally desires to consult the original sources of information which has been published. To encourage this practice, the author refers him to The Journal of the Royal Microscopical S'ociety, Archir für mikroskopische Anctomie, the Zeitschrift für wissenschaftliche Mikroskopie, Merkel and Bonnet's Ergshuisse der Anetonir und Enturicklungrgrsehichte, and Anatomische Hefte, in which aldstrates of the current literature will be found. Admirable textborks upmn technique are Lee's Microtomist.s' V'ade Jecum, of which a more reent revised edition is Lee and Mayer's Ginudzüge der mikroskopisechen Techuik, and Mallory and Wright's Puthologieal Tecelninipue.

E. K. D.

336 EA-T TWINT--IXTH St.

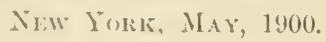




\section{CONTENTS.}

CHAPTER 1.

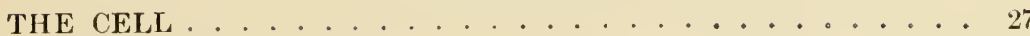

CHAPTER II.

THE ELEMENTARY TISSUES ............. 43

CHAPTER III.

THE EPITHELIAL TISSUES . . . . . . . . . . 47

CHAPTER IV.

THE CONNECTIVE TISSUES . . . . . . . . . . 65

\section{CHAPTER V.}

TISSUES OF SPECIAL FUNCTION

CHAPTER VI.

TISSUES Of SPECIAL FUNCTION (Continued) . . . . . . 100

CHA PTER VII.

THE ORGANS

C'HAPTER VIII.

THE CIRCULATORY SYSTEM ................. 11 t

CHAPTER IX.

THE BLOOD AND LYMIII 
THE DIGESTIVE OLGANS ....................... 136

('HAPTER XI.

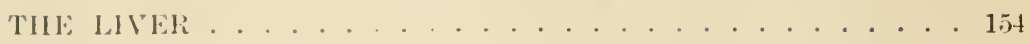

CIAP'TER XII.

THE URINARY ORGANS ............... 161

CHAPTER XIII.

THE REPIRATORY ORGANS ................. 176

C'HAI'TER XIV.

TIIF, SPLEEN 184

\section{CHAP'ER XV.}

THE DUCTLESS GLANDS . . . . . . . . . . 188

CHAPTER XVI.

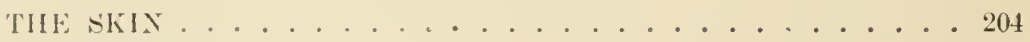

CIIAPTER TVII.

THE HEPRODLCTIVE ORITAS

('HAPTER XVIII.

THE CLNTRAL NERVOLS SYNTEM . . . . . . . . 248

('HAP'TER XIX.

TIE OR(IANS OF TIE SPECIML SENSES . . . . . . 266

HISTOLORCAL TECHXIQTE.

CHAPTIR XX.

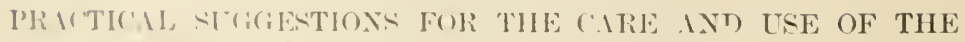

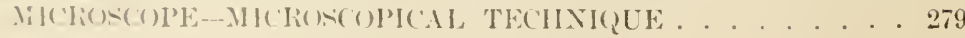




\section{NORMAL HISTOLOGY.}

\section{INTRODUCTION.}

Durivg life all parts of the human body are the seat of constant activity. This is a fact too readily overlooked by the student who gains his knowledge of the structures of the body by a study of the tissues after death. To make that study of use to him in his medical thinking he shonld constantly bear in mind that he is riewing the mechanism of the body while it is at rest, and, furthermore, that the methods employed in the study of the minute structure of the parts not only arrest the normal activities of those parts, but expose them to mutilation. He nust, therefore, constantly supplement the knowledge of structure he gains by his histological studies by recalling to mind and applying that which he has acquired by a study of physiology, habitually associating his ideas of structure and functional activity, until he can hardly think of what a structure is without at once recalling what it does. This he camot do till he has mastered at least the general outlines of systematic anatomy and of physiology. Those two fundamental subjects arn bronght together by an intelligent study of the minute structure of the body, histology, which, for this reason, has also and appropriately been called physiological anatomy.

But the student of medicine must go beyond this. To the conception of the body during health, which he has formed by this thoughtful method, he must then add a eonception of the influence exerted, both on the structure and activities of the body, by abnormal conditions which disturb or thwart the ustial working of that complex mechanism. The more closely he can make those conceptions agree with observed facts, the more perfect will become his ability to interpret the physical signs and symptoms of disease, 
and the clearer will growir his in-ight into the canses and tendencies of the proceses of which they are an expression.

In all his studies be must seek not merely to train his powers of observation; he must encleavor to cultivate his ability to interpret what he sees; to deduce the processes and causes that have wronght the results he perceives, and to compare those deductions witl the conceptions of living things he has already formed, so that his idcas may remain in perfect accord with one another as his grasp of the subject enlarges. By so doing he may hope to create a lifelike mental picture of the body both in health and during disease.

The activitics of the body involve changes in the substances of which it is composed. Some of these changes are always destructive in character-that is, they result in chemical rearrangements which convert more complex combinations of less stable nature into simpler combination of greater stability. Such chemical changes, whether they take place within the body or in external nature, among organic or inorganic substances, are always accompanied by a liberation of energy hitherto locked up or stored in latent or potential form in the componnds of higher complexity. It is this liberated or kinetic energy which is utilized by the bodily mechanism for the performance of internal or external work. When directed in varions ways and operating throngh different structures, this energy necasions visible movement, appears as heat, ete, or passes again inte the latent form in the elaboration of more complex clemical substances from those of simpler constitution.

These ascociated transformations of matter and energy involve a contimal loss to the bodily economy. The stock of energy is diminisher during the execution of external work and by the discipation of heat. The store of useful chemical substances is reduced by their progresive conversion into compounds that are insusceptible of further utilization, and which, in many cases, may act injurious ly upon the structures of the body. Under normal conditions such substances are eliminated from the body.

It is evident, then, that the body is constantly suffering a loss of both encery and matter. This loss must be made good if the activities of the body are to he mantained, and this is accomplished, during lealth, throngh the absorption of fresh material, containing latent energy, from the food taken into the body.

The activities of the body are not the same in all its parts. They are all alike in one particular-namely, that each part must main- 
tain its own nutrition, ineorporating the foor-materials that are accesible to it and using them in such a way as to keep its structure in a normal condition. But, aside from this duty which is common to all, each part has a duty to perform for the good of the whole organism ; and, as we shall see, this duty often appears to be paramount, the activities which it necessitates being carried on even if they involve a sacrifice in the nutrition or structure of the inclivichal part.

Each part of the body has some particular kinds of work assigned to it, which constitute its functions, and which it performs for the benefit of the whole body. The development and life-history of each part has clirect reference to those functions, through which it o-operates with all the other parts in maintaining the integrity and normal activities of the whole body, all the parts being interdependent upon each other and subservient to the general needs.

'The foregoing considerations prepare us for the fact that the structure of the various parts of the body differs in its details. The study of those finer details ean only be pursued with the aid of the mieroseope, for the microscopieal constituents of the tissues are the elements which eonfer upon them their particular properties and powers. 'This study is called histologr.

Investigation las shown that there is one form of tissue-element which is always present in all parts of the body. This is the cell. It does not always possess the same form or interual structure, but in all its variations the same general plan of construction is adhered to. These cells are the essentially active constituents of the tissues. It is within them that the transformations of matter and energy are chiefly earried on, and it is due to their activities that the tissues forming the bor?y are elaborated and enabled to perform their several functions. These marvellous powers possessed by the cell have ereated our conception of life, and, in spite of eager study, remain inscrutable. We do not know why a living cell differs from a dead cell, but we do know that the mysterious vital powers are only derived from pre-existent living cells and are not antagonistic to the chemical and physical laws governing unorganized matter.

All the cells of the borly are descendants of a single cell, the egg, from which they arise by suceessive divisions, and throughout the existence of the body they retain some of the characters of the original cell. But as the body develops the cells of the different parts display divergent tendencies, which finally result in the formation of a considerable variety of tisines, grouped in varions ways 
to form organs or systems of very different kinds of utility to the whole organism. This divergent development is known as differentiation and results in a specialization of the different parts of the body. Its study constitutes embryology, but it will make the eomprehension of histology easier if some of the simpler and hroader facts derived from a study of development are first briefly summarized.

A new individual arises through the detachment of a single cell, the orum (Fig. 1), from the parent organism. This cell, after undergoing eertain molifications and mion with another analogrously modified cell (see Maturation of the Orum), divides FIG. 1 .

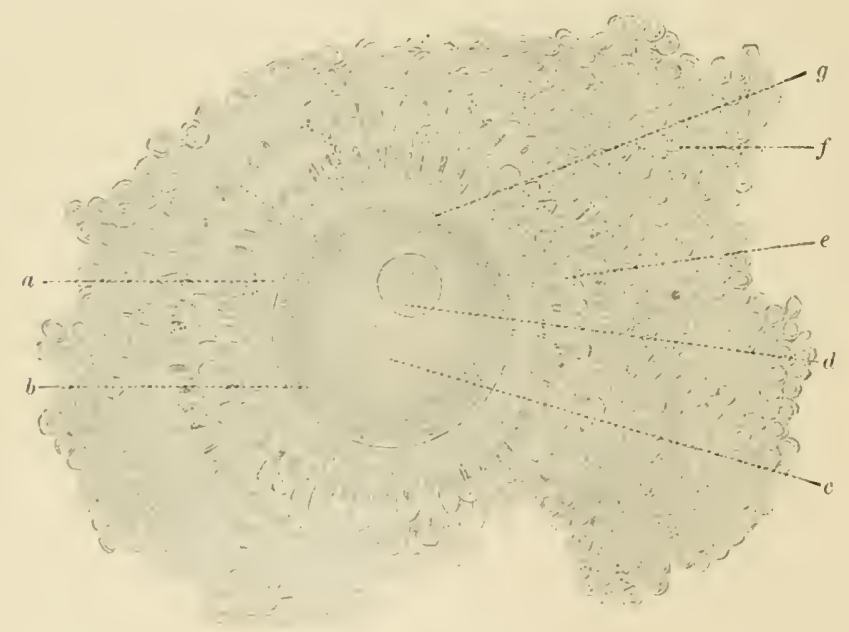

Section of human ovum and its immediate surroundings within the ovary. (Nagel.) a, zona peliucida; $b$, cytoplasm of the ovuu ; $c$,grauules and globules of stored food materials within the cytoplasm, collectively known as the metaplasm or deutoplasm; $d$, germinal vesicle or nueleus of the ovum containing, in this ease, two germinal spots or nueleoli; $e$, zone of epithelial cells immediately surrounding the ovum; $f$, cells of the diseus proligerus; $g$, derivitelline spaees separating the zona pellucida from the cytoplasm of the (1)11m.

into two celli, which, even at thin stage of development, differ slightly from each other. These daughter-eells in turn divide in two, and this process of tivision is rontinued, each cell giving rise to two new eells, until a consileral, le aggregate of cells has resulted (Fig. 2). Then the cells assume a tefinite arrangement into layer:s. some berome disposed in a superficial layer enclosing the rest of the cells and a hody of fluid. This layer is called the primitive cetorlerm. The remaining rells accumulate in an irregular laminar ma-s beneath the primitive retolerm at the site of the future embryo. This mass of erels is the primitive entorlerm. Thus, at 
this stage of development, there is a cellular sae, containing fluid, with a reinforeement of its wall at the region oeeupied by the primitive entoderm (Fig. 3).

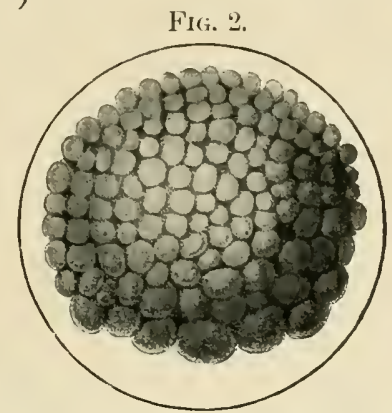

Segmented cgg of Petromyzon Planeri : Surface view of the collection of cells. The nuclei are invisible. (Kupffer.)

Subsequent to these events a third layer of cells becomes interposed between the primitive ectoderm and entoderm. Most of its

FIG. 3.

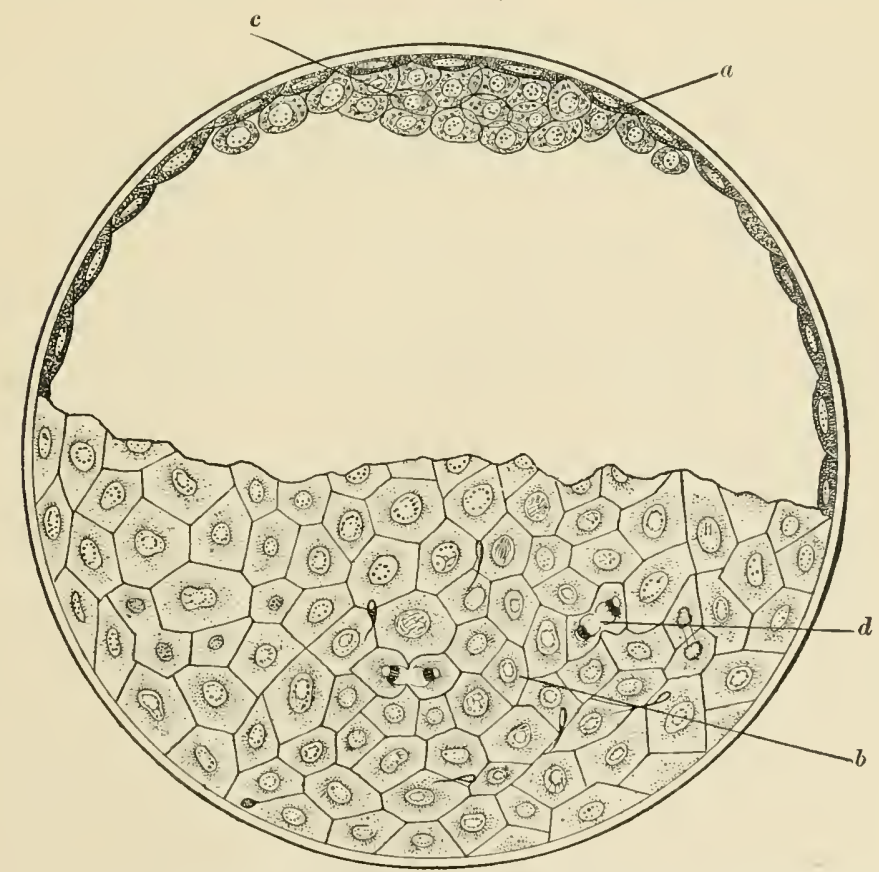

Ovum of rabbit: $\alpha$, primitive ectoderm in section; $b$, primitive ectoderm, surface view ; $c$, primitive entoderm; $d$, dividing cell of the ectoderm. (van Beneden.)

cells are derived from those of the primitive ectuderm, but the 
primitive entoderm may also participate in its formation. This third layer is ealled the mevolerm. Soon after its formation, the mesoderm divides at the sides of the embryo into two layers-a parictal, which joins the under surfice of the ectoderm, and a visceral, attached to the upper surface of the entoderm. The space between these two layers is ocempied by fluid, and is destined to form the future body-cavities. In the axis of the cmbryo the three arlier layers remain in eontinuity, forming a cellular mass around the site of the future spinal column (Fig. 4).

Fig. 4.

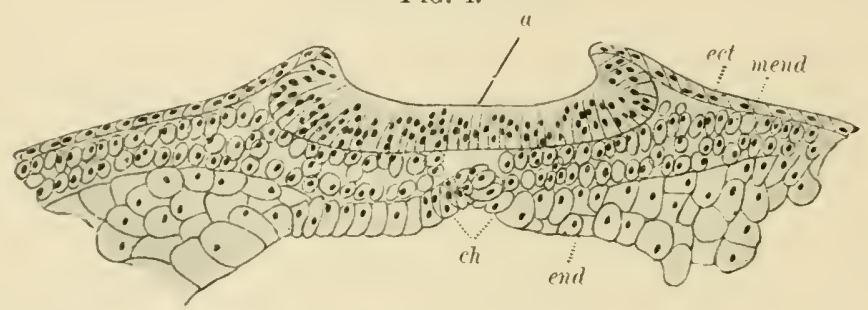

Embryo of Necterus in cross-section. (Platt.) ect., ectoderm; mend., mesoderm; end., entoderm ; $a$, neural groove; $c h$, site of future spinal column.

From these three embryonic layers of cells the body of the foetus is developed. The entoderm, with the viceeral or lower laver of the mesoderm, turns downward and inward to meet its fellow of the opposite side and form the alimentary tract. The eetoderm and parictal or upper layer of the mesoderm also turn downward and inward, outside of the alimentary tube, and join those of the other side to form the walls of the body.

Meanwhile, the upper surface of the ectoderm over the axis of the embryo becomes furrowed. The edges of this furrow grow upward, deepening the gronve between them, and finally areh over it and roalecee, forming a canal aromel which the entral nervons system is developed (Fig. 5). Traces of this canal persist through life ats the central canal of the spinal cord and the ventricles of the brain.

The embryonic layers have a deeper significance than the mere furnishing of the architectural materials from which the body is huilt "1p. They are evidenees of a distinet differentiation in the develnpmont of the eells of which they are composed. The ectoderm gives rise to the functional part of the nervous system and the sperial senses and to the eprithelial structures of the skin and its appentages. The cell- of the mesoderm claborate the muscular 
ti-sues and that great gronp known as the eomnective tissues, the vistular system, ete., and the entoderm contains the cells that build up the linings of the digestive tract, including its glands, and of the respiratory organs. It appears, then, that this division of the cells of the embryo into three layers marks a distinct difference in the destinies of the cells composing those layer.s. This distinetion persists through life, the tissues arising from a given layer showing, in general, a closer relationship to each other than the tissues arising from different layers. But this relationship is not always revealed by a similarity in strueture, for the latter is determined by the functions the tissnes are destined to perform, and tissues of like funetion aequire a similarity in strueture. Thus, for example, the neuroglia in the central nervous system resembles

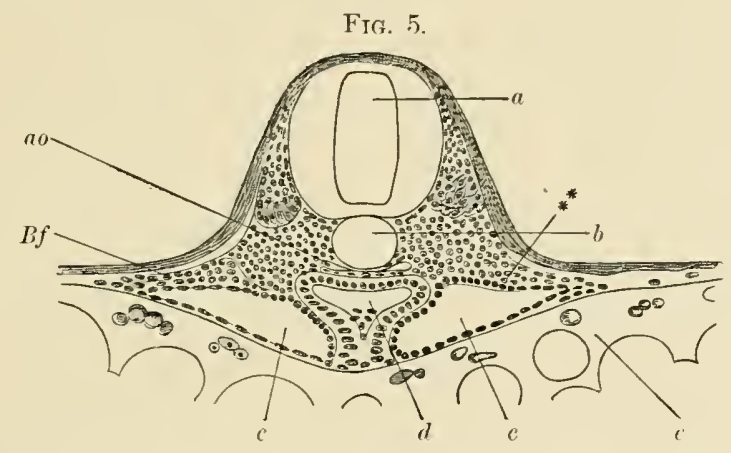

Cross-section of fish embryo. (Ziegler.) a, neural canal, cells enclosing it not represented; $b$, chorda dorsalis, site of future spinal column; ao, aorta; $B f$, external layer of mesoderm; $c, c$, body-cavity; $d$, alimentary canal, not yet completely closed $* *$, passes through the external layer of the mesoderm to its inner surface; $e$, deutoplasm, or yolk of egg.

some of the connective tissues, although one develops from the eetoderm and the other from the mesoderm; and the ganglion cells of the central nervous system differ greatly in structure from the epithelium of the skin, nails, ete, and the cells of the neuroglia, notwithstanding the fact that they all spring from the cells of the ectoderm. The explanation is to be sought in the similarity of the usefuhness of neuroglia and connective tissue and the difference in the functions of ganglion cells and those of the other tissues emanating from the ectoderm.

During the early stages of development the cells of the germinal layers are very similar in charaeter, although, as we lave seen, 
their potential qualities are quite cliverse. Is growth proceeds, they begin to vary in size, shape, and internal strueture in the different parts of the foetus. Their relative positions become modificd. The primitive organs are defined and the tissues of which they are composed become elaborated. In this elaboration of the bodily organs, cells from the different embryonic layers enter into rery intimate coöperation, nearly all the organs of the body containing structures derived from all three lavers; thus, the lungs, for example, contain epithelium which is descended from the entoderm ; fibrons tissue, cartilage, and bloodvessels from the mesorlerm, and nerves and ganglia arising from the ectoderm.

The elaboration of the tissnes is wronght by the cells, which display what is called their formative powers in the production of materials of varions sorts which lie between them, and are called the intercellular substances. The amount and kind of intercellular substance vary, each form of tissue having its own peenliarities in this respect, dependent upon the ofle it is to play in the general economy. Some of the tissues perform functions which require the active processes that can be carried on only in cells, and in these the intercellular substances are either small in amount and apparently structureless, ats in epithelium, or their place is taken by a tisne of separate origin, while the cells, relieved of the necessity for exercising their formative powers in this direction, become highly specialized to meet the functional demands imposed upon them. This development is met with in the muscular and nervous tisisues.

Other ti-sues of the boly are of use mainly becanse of their physical properties, such as rigidity, elasticity, tensile strength, pliability, cte. These tissues, collectively called the connective tissnes, are essentially pasive. They require little or no cellular activity for the performance of their functions, and it is in the elaboration of the e tisures that the cells exereise their most marked formative powers during the development of the body, cansing the deposition of interenlular substances which poseses the requisite physical charaeters-richidity and elaticity in the case of bone, pliability and tensile strength in the ease of ligamentons structures, ete. As these snb-taneer are perfecterl, the cells decroase in activity, until they mercly prowils over the integrity of the intercellular substances they have already preduced. 
It may be well to point out here a distinction that divides the tissues of active cellular function into two groups. 'The first group, ineluding the various morlifications of epithelium, displays its activity in the elaboration of material prodncts, taking the form of cither new eclls which are continually being produced, or of certain rhemical substances which appear as a secretion. The second crroup, comprising the muscular and nervous tissues, exercises its functional activities in the storage of latent energy in such substances of mostable chemical nature and in such a mamner that it can be liberated when required and directed toward the accomplishment of some definite purpose. The functions of looth groups require an aetive intracellular metabolism, resulting in the formation of particular chemical substances. In this they are alike. But in the first group the production of those substances is, in itself, the functional purpose of the process, while in the second group those substanees are merely a means for holding energy in the latent condition. If we may so express ourselves, the first group utilizes energy for the elaboration of matcrial, the second group elaborates material for the utilization of energy.

In the adult, under normal conditions, each kind of cell, if it reproduce at all, gives rise to cells only of its own kind. But when the conditions are morbil, this is not always the case, the progeny of a given cell under abnormal couditions may appear less highly specialized than the parent stock or may differentiate in a somewhat different way. 'These departures from the nomal appear never to transcend the legree of specialization that is marked by the formation of the three embryonic layers in the early history of devclopment; for example, epithelium which springs from either the entulerm or cutoderm never gives rise to bone or any other variety of connective tissue normally developed from the mesoderm.

The eells of the body differ greatly in their individual permanency. Some are apparently destined to endure throughout the life of the individual. Among these are the nerve-cells and those forming muscular tissue. Other cells have a comparatively short lifenistory. This is true of many of the epithelial cells, which undergo transformations, ultimately learling to their destruction-e.g., the superficial cells of the epielermis and those cells which yidel the secretion of sebaceous glands; or they are destined to proliferate, 
losing their identity in a multitude of descendants that are sulbequently destroyed in the performance of some useful function. Finally, some of the embryonic cells form structures of only transient utility-e. g., the thymus and Wolffian borly-which partially di-appear is the individual hecomes older. It follows, then, that we must regare the tissues of the body as more or less plastic and capable of some degree of adaptation to the conditions presented by the whole organism. 


\section{CHAPTER I.}

\section{THE CELL.}

As has been stated in the introductory chapter, the cells of the body are not all alike. Most of them have undergone modifieations fitting them for the performanee of some definite function, and the majority of them are in consequence not appropriate objects for a study of the general characters of a cell. The extent to which this modification has affeeted the visible structure of the cell is, however, very different in the different tissues, and in some of them the cells retain so much of their original embryonic appearance as to closely resemble the unspecialized cell.

This is true of the cells of some varieties of epithelium. But, thongh in appearance they give little evidence of specialization, in their functional aetivities they display very marked modifieations of the powers of the primitive cell. Some of those powers, perhaps the nutritive, perhaps the secretory, have become exaggerated, while others, e.g., the locomotory, or reproductive, have fallen into abeyance, or suffered almost total extinetion.

On the other hand, it is obvions that such cells as constitute the whole body of unicellular animals must retain all the powers essential to a living eell in relatively equal states of development. No one of them ean be extinguished or thrown out of its proper balance with respect to the others if the eell is to remain normal. And yet, even among the unicellular organisms, certain parts of the cell may be very evidently specialized for the performance of particular functions. For example, the eilia of infusoria have the power of executing much more rapid movements than the other parts of the same eell. And it is probable that all protozoa, i. e. unicellular animals, possess similar, though less obvious and internal, heterogeneity of constitution.

The less the degree of specialization or differentiation in the strueture of an organism, the less highly developed is the funetional aetivity of which it is cupalle, and the less perfect its ability to cope with possible unfavorable environment. The value to the 
whole organism of a diversity in its parts is, therefore, mnquestionahle, and the higher we go in the animal kinglom, the greater we fiml the development of this diversity, eotpled with a more and more perfectly aljusted co-operative interdependenee of the different parts of the body.

In the protozoa the single cell does all the work of the whole organism. In the multicellular animals, the metazoa, this work is distributed among the component cells of the body, each of which has dereloped an effieieney for performing its special work that would be ineomplatible with a wider range of duties.

It is quite imposible to find in nature any example of a cell devoid of all individual peeuliarities attributable to differentiation or specialization. We must, therefore, study several varieties of

FIG. 6.

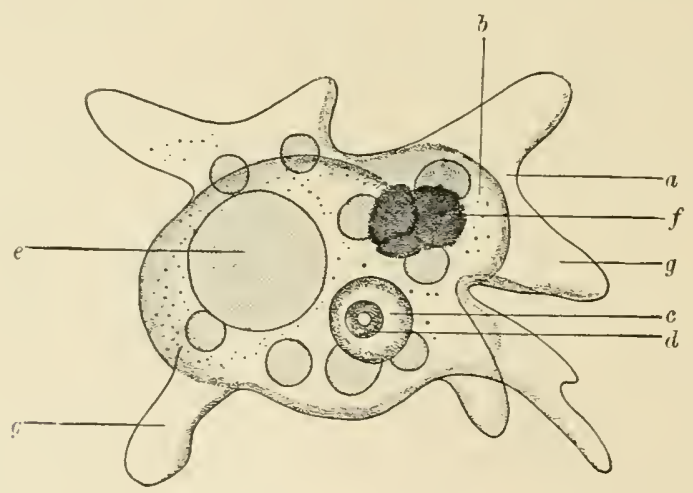

Amceba pellucida. (Frenzel.) $a$, ectoplasm; $b$, endoplasm ; $r$ nucleus; $d$, nucleolus; $c$, large contractile vacuole; $f$, ineorporated foreign body; $g, g$, lseudopodia. (It is impossible in a line-clrawing to reproduce the great translucency of the hyaloplasm and the smaller pseurloporlia. The outlines of the latter are so faint that it freciuently requires close attuntion to detect them.)

cell in orek to gatin an ideal conception of such a cell. This aceomplished, we may comsider those cells which vecur in uature as speeial molifications of that type.

I'rrhaps the -inplent eell leading an independent existence is the protozun, amabar (Fig. 6). There are several speeies of ammebe which difter in their morphology, showing that even these simple oromi-ms di-play consiterable differences in structure. These animals: are willely distributed in moist cartl, upon the surfaees of alpuatic plante, and in the soil at the margins of ponds and sluggish $-\operatorname{tr}(1111 \leqslant$. 
The body of the amneba consists of a grelatinoid substance which has received the name protoplasm, or, more definitely, cytoplasm. Within this eytoplasm and sharply defined from it is a round or oval, vesicular body, called the mucleus, which in turu contains one or more particularly conspicuous granules, the nucleoli.

The most superficial layer of the eytoplasm appears perfectly clear, colorless, and homogeneous. It enrelops the rest of the eytoplasm, which has a granular appearance. The clear peripheral portion is distinguished as the "hyaloplasm," or "eetoplasm ;" the granular internal portion as "spongioplasm," or "endoplasm." The terms hyaloplasm and spongioplasm are also used in a different and more restricted sense, as will presently appear.

When viewed under the microseope, the granules of the cytoplasm are seen to possess a constant, slight, vibratile motion, the Brownian movement, to which is adder now and then a flowing movement from one part of the cell to another. At intervals there is a protrusion of the ectoplasm at some point, extending for some distance from the body of the cell, a psendopodium. This may soon be retracted again, merging with the rest of the ectoplasm, or some of the endoplasm may flow into the central portion of the pseudopodium, converting it into a broad extension of the cell-body. This may subsequently be withdrawn, or the whole mass of cytoplasm, with the nucleus, may flow into the psendopodium, gradually increasing its size, until the whole cell occupies the original site of the psendopodium. In this way the animal exeentes a slow, creeping locomotion.

These psendopodial movements and the locomotion oceasionally incident to them appear to be wholly spontaneous, i. e. dependent upon internal conditions of which we have no knowledge, but they are manifested only when the amoba is in contact with some other body, not when it is floating freely in a lingid. They may, however, be influenced by extemal circumstances. Certain substances evidently attract the amoela, others are either matters of indifference to it or repel it. The cliemieal nature of the substance or soluble materials emanating from it induce these reactions on the part of the cell. Where this is the ease the phenomenon is called chemotropism or chemotaxis, and may be either "positive" or "negative" according to whether the cell is attracted or repelled. Similar reactions induced by light are included in the term heliotropism, which may be positive or negative. The effect of gravity in its relations to cel- 
lular movements is ealled geotropi-m and may have either sign. Colls may also (ither seek or he repelled by moisture (lyydrotropism), or by electric (anrents (galvanotmpism). If a psecudopodium comes in contact with some particle in the surrounding medium, it may retreat from it, appear indifferent to it, or be attracted and proced to incorporate it. This is accomplished by the eytoplasm flowing around the forrign body and coalescing on its further side so als to enclose it. It is then convered to the body of the cell, either by cytoplasmic currents, ly the withdrawal of the pseudopodium containing it, or ly the streaming of the cell-body into that protrusion. The fate of the particle thus incorporated depends upon its nature. If it be serviceable as fool, it is gradually digested and absorberl, or such parts of it as are digestible are $s$ utilized, and the remainder, no longer of nse to the amcebil, is extruded from its londy.

These phenomena reveal powers of pereeption and selection on the part of this cell which are very closely alkin to the intelligence of more complex oryanioms. They also demonstrate its power of ascimilating material from without, to serve as nourishment and the souree of the encrgy which it expends in executing its movements and in earrying on the ehemieal processes pertaining to its internal ec(onomy.

At intervals, there appears within the endoplatim a small, elear, spherical pot. This gradually increases in size and constitutes a little drop of Huid, sharply defined from the surrounding eytoplasm. $\Lambda$ fter it has attained a certain size, it suddenly dizalpears, the eytoplatim around it coalescing and leaving no trace of its existence. Such a clear spare, filled with fluid, within the body of a cell is called a vacmole, and those which are suddenly ubliterated, contractile vacuoles. Their purpose is not elearly understood, but prolably has to do with a primitive cireulatory or respiratory function, since contractile vacuoles are not observed in the cells of higher organi-ms where those functions are carried on by more elaborate mechanisms. Many micellular organisms possess contractile racuole, hut it is by no means esential or characteristic of the protozoa ; for the majority of species composing that group of organisms are deverid of such vacuoles.

Eventually the anceba reproduces its kind by dividing into two sinilar cells, cach of which grows into a likeness to the parent individual. 
Let us now compare the amoba with some other variotics of cell, in order to learn what they all have in common.

The amneba has an onter, soft, transparent layer of cytoplasm, the ectoplasm. This is not present in all cells. In many the granular cytoplasm has no envelope, but appears to be quite naked. In other varieties it is enclosed in a distinct membrane.

In the great majority of cells the active streaming of the cytoplasm and the psendopodial protrusions described in the amoba are wanting, but the Brownian movement of the gramules is more constantly present. The cells have fixed positions and their food is brought to them, usually in solution, so that the more active movements so essential to the welfare of the amceba would be superfluous. For a similar reason, as already stated, they can dispense with the contractile vacuole.

We learn, then, that when we reduce the cell to its simplest terms, it consists of a mass of cytoplasm enclosing a nucleus. To these we must probably add a third essential constituent, the centrosome, which is a minute gramule situated in the cytoplasm. It is so small that its presence has not been established in all cells, its detection in many cells being extremely difficult because of the general granular appearance of the eytoplasm in which it lies. It plays such an important part, however, in the division of those cells in which it has been sturlied, that the inference that it is an essential part of all cells appears justified.

These three constituents, the eytoplasm, nucleus, and centrosome, appear to be the essential organs of a cell among which its activities are distributed (Fig. 7). We do not know how they do their work, but we have a general conception of the distribution of the work performer by the whole cell among these three organs.

1. The cytoplasm, which usually makes up the chief bulk of the cell, espeeially in those varieties which have active metabolic functions, appears to be the part of the cell in which the assimilated food is utilized in the production of ehemical substances, either fresh cytoplasm or some other product, or in the execution of movements or the liberation of energy in other forms. Most of the active processes that are obvious seem to be earried on in the cytoplasm during the greater part of the life-history of the eell. Many of these processes involve highly complex chemical transformations. Some of these are syntheses, or the building up of more complex molecules from those of simpler constitution, and are called anabolic processes or anabolism. 
Others con-ist in the clavago of larger molerules into smaller atomic gerom which may vanionsly mite with each other, chemical changes designated as catabolic (cataboli-m). Similar clearages may be oceasioned outside the body ly various procedures employed in chemical manipulations, hut minally require powerful reagents in concentration not mot with in the body or the applieation of heat greatly exceeding that compatible with life. It is believed, upon experimental evidence, that these chemical changes within the cell

FIG. 7.

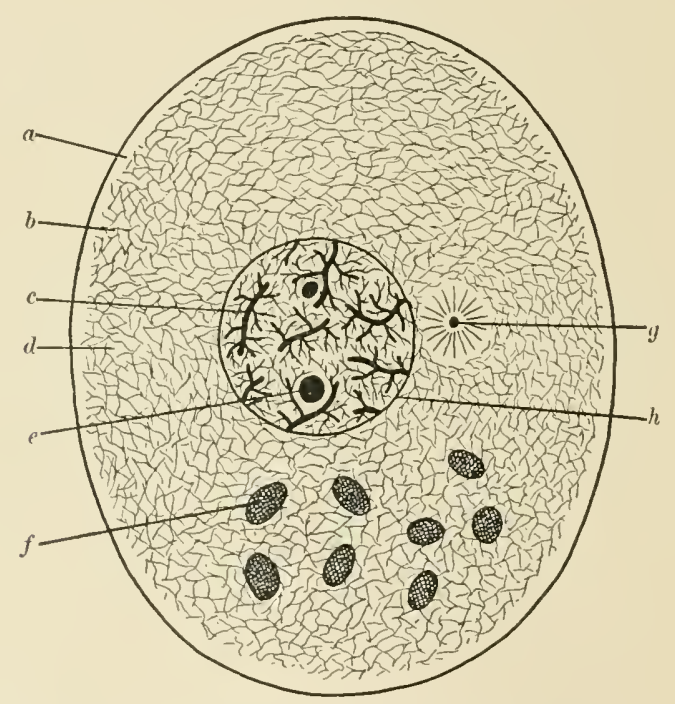

Sehematic diagram of a cell : $a$. ectuplasm composed of hyaloplasm; $b$, spongioplasm; $c$, chromosome, composed of "chromatin," and forming a part of the intranuelear retieulum; between these chromatie fibres is the achromatin; $d$, hyaloplasm in the meshes of the spongioplasm; $e$, one of the two nucleoli represented in the diagram; $f$, one of eight bodies constituting the metaplasm representer; $g$, centrosome, with radiate arrangement of the surroumding spongioplusm: $h$, nuelear membrane.

are wrought with the aid of ferments or anzymes, chemical substances prodneal by and present in the eoll, which have the power of fiveilitating chemical reactions and molifying the conditions moler which they take place, so that the plane "pon which chemical equilibrimm is cistablished is shifted to a different level in the presenee c.f ferments form that which it ocempies when the enzymes are alsent, if one may ha permitted to nse such an illustration. A study of such transformations (onstitutes a special fielel of chemistry, biochemistry, in which great advances are being made. 
2. The nucleus appear to preside over the asimilative processes within the eell. If a cell be subdivided so that the uninjured nuclens is retained in on of the portions, that portion may grow and become a perfect cell. But the portions that are deprived of a nucleus do not grow, and while they may retain life for a considerable time, ntilizing the assimilated food they retain, eventually perish.

Aside from this assimilative function, the mucleus appears to be the carrier of hereditary characters from the parent eell to its progeny during the division of the cell. This will become elearer when the process of cell-division is deseribed.

3. The centrosome appears to be the organ presiding over the division of the cell. It inaugurates those activities in nucleus and cytoplasm which result in the production of new eells, and seems to guide them, at least during the greater part of the whole process.

It is evident, from these statements, that the cell has an exceedingly complex organization, which a simple microscopical study cannot wholly reveal. Notwithstanding this fact, obvious microscopical differences are presented by cells which have become specialized in different directions, and we must know something of the visible structure of the primitive cell before we can appreciate these departures from it.

The eytoplasm is not a simple substance. Its constitution is so complex that our present means of research are not adequate to reveal its structure. We know that its solid constituents are chicfly proteids, together with relatively small quantities of carbohydrates, fats, and salts. To these is added a large proportion of water which, while not entering into a definite chemical union with the other constituents, is so intimately associated with them as to form an integral part of the cytoplasm.

The visible structure of cytoplasm differs somewhat in different cells, even among those that appear to be comparatively unspecialized. In the fixed cells of the higher animals and man it appears to consist of a very delieate network or reticulum of minute fibres, termerl the spongioplasm. The points of junction of these fibres and their optical eross-sections give a finely granular appearance to the eytoplasm.

In the meshes of the spongioplasm is a clear, homogeneous substance, the hyaloplasm. This may also contain sone granules, but they are probably not constituent parts of the eytoplasm and are grouped under the term metaplasm. Some of them are composed 
of material taken from without, either in their original form or slightly modified; others have been protueed within the eell by chenical transformations, and are either useful products, to be sul)sequently turned to aceount by the cell itself or to be discharged as a seeretion, or they are waste matter destined for elimination from the body.

The relative proportions of the hyaloplasm and the spongioplasm and the arrangement of the fibres of the latter both vary in different cells. ${ }^{1}$

When seen under the microscope the structure of the nucleus, except during the division of the cell, closely resembles that of the eytoplasm. It is traversed by a number of delicate fibres, which branch and give the nucleus a reticulated appearance. At its surface these filaments unite to form a delieate membranons envelope, sharply defining the nucleus from the surrounding cytoplasm, but it is a question whether this membrane is continnous, or whether it is an exceedingly close meshwork with minute apertures permitting a direct communication between the eytoplasm and the interior of the nucleus.

The intrannclear reticulum varies in character in different kinds of cell. In some its filaments are delicate and the meshes relatively large. In the other extreme the filaments are so thick and closely sot that the nucleus appears to contain little if anything else. Between these extremes there is a great variety of intermediate variations in the relative amount of reticulum.

The spaces between the nuclear filaments are occupied by a clear, homogeneous substance (karyoplam or nuclear sap), which may be identieal and continnous with the hyaloplasm of the rest of the eell.

One or more highly refracting loclies, the nucleoli, may be present in the nuclens, lying frecly in the clear substance between the filaments or attached to the latter. Their purpose is not known, but it is thonght that they are not essential parts of the cell but corre-pond more or leis closely to the metaplasm in the cell-body.

Owing to their affinity for certain coloring matters, the substances composing the nudear filaments are ealled ehromatin, or chromo-

1 The reticulated appearance of the cytoplasm may also he explained by assuming it to have an alveolur structure, and the theory that such is its actual structure pussesses much plausibility. In that case the visible reticulum would be formed by the walls of the alvenli and their lines and points of intersection, all of which would be inchuled in the spongioplam, while the contents of the alreoli would constitute the hyaloplasm. A tine emulsion presents such an apparent structure. 
plasm. The hyaline substanees making up the rest of the nueleus do not receive those coloring matters, and for this reason and in this situation are called achromatin. These terms are used only in a morphological sense and do not speeify any definite chemical compounds, though they are distinguished from each other by staining affinities which are based on ehemieal differences. The chromatin has been further resolved into a ground-substance, giving form to the reticulum of the nueleus and ealled linin, and to granules of elromatin (the term heing used in a more restrieted sense), and this ehromatin has in turn been subdivided aceording to staining eharacteristics, into oxyehromatin (or lanthanin) and basichromatin, embedded in the linin in the form of minute granules. The achromatin has also been observed to contain granules, not stained with the usual nuclear dyes, which have been ealled nedematin granules. The behavior of the nucleoli toward dyes is somewhat different from that of the chromoplasm, which leads to the inference that they are of a different chemical nature.

Except during cell-division, the nueleus usually lies quieseent within the cytoplasm, but some observers have seen it exeeute apparently spontaneons movements, and it is evidently possible for its position in the cell to vary from time to time.

In marked contrast to this apparently dormant state, as far as visible alterations of strueture are concerned, is the rôle played by the nuclens during the reproduction of the eell.

There are two modes of cell-division, the "indireet" and the "direet," but they are by no means equivalent to each other. The former, also termed karyokinesis becanse of the active changes in the nucleus, appears to be the only truly reproductive process. Direct cell-divicion results in the formation of new cells, but they seem to lack that perfection of organization which would be required for the complete and indefinite transmission of all the eharacters of the parent cells.

Before entering into a deseription of karyokinesis, a few words must be said concerning the centrosome. This is an extremely minnte granule which is nsually situated in the cytoplasm not far from the nuelens. It is often surrounded by a thin zone of hyaloplasm which facilitates its reeognition among the fibres and nodal points of mion of the spongioplasm. The fibres of the latter are also frequently arranged in a radial manner for a short distance around the centrosome. But in many instances it is extremely diffieult to dis- 
tingui-h the centrosome, and its constant presence in cells is largely a matter of inference. Sometimes the centrosome is double, the two granules lying close to each other and often being surromided by a common clear zone of hyaloplasm.

The first step in the proces of cell-division by the indirect methorl, or kiryokinesis, is a division of the centrosome into halves (Fig. 15), which separate and pass to opposite points in the eytoplasm. These points are called the poles of the cell, and when the new centrosomes reach them they are called the polar bodies. In these situations they are surrounded by a more distinet zone of hyaloplasm than that which enelosed the original parent eentrosome, and beyond this the spongioplasm is frequently arranged in radiations of unusually thick fibres. The polar bodies with their clear envelopes and the prominent radiations about them are collectively known as the attraction-spheres (Fig. 8).

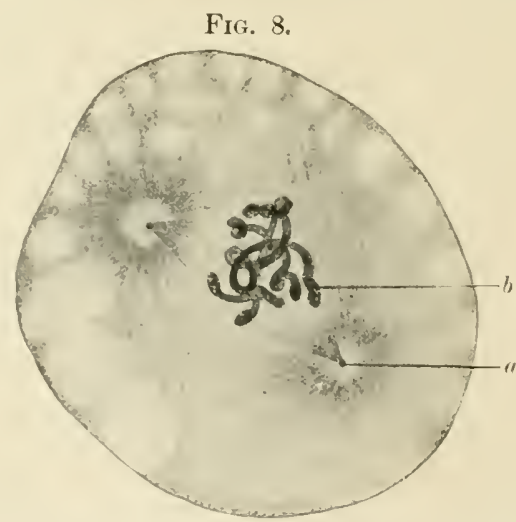

Dividing cell from ovum of ascaris megalocephalus. (Kostanecki and Siedlecki.) a, polar body, centrosome, surrounded by a clear zone; $b$, chromosomes of the dividing nucleus. Between the polar bodies is the achromatic spindle, and radiating from eacl attractionspherc are delieate flaments of spongioplasm. The eytoplasm presents indications of vacuolation.

While the polar bodies are separating, or after they have passed into the polar regions of the cell, the nueleus begins to show those changes in strueture which constitute karyokinesis. This process may be divided into a number of phases, als follows:

1. The Formation of the Spirem (Fig. 9).-This consists in a cordensation of the elnomoplam. The branches of the nuclear filaments are withdrawn into the sulstance of the main fibres, into which the nuclear membrane or peripheral network bounding the 
undeus is also absorbel. 'The vesicular character of the nuclens is lost during these changes in the arangement of the chromoplasm, which appears as a loose tangle or skein of one or more threads of miform diameter lying freely in the borly of the cell. This skein is called the spirem. The chromoplasm in this condensed condition stains more deeply with nuclear dyes than in the resting condition of the mucleus. The nucleoli in the meantime become faint and scem to ultimately disappear. 'They play no part in the process of cell-division, mless they participate in the formation of the achromatic spindle.

2. The Monaster Phase (Fig. 10). - The threads of the spirem suffer a rearrangement, resulting in the formation of a sort of wreath, situated midway between the poles, in the equatorial plane, $i$. $e$, the plane perpendicular to and passing through the centre of a line joining the two polar bodies. This wreath is called the monaster, because of its star-like configuration when seen from above. When viewed in profile it appears as a band of fibres lying in the equator. It is at first made "p of a single threar or only a few threads, but subsequently breaks into a number of similar fragments, called chromosomes. The exact number of these varies in different species of animal, but is constant for each species and is always divisible by two. In man it is thought to be sixteen.

The chromosomes are all of nearly, if not quite, the same size, and, in the same kind of cell, closely resemble each other in shape. The most common form appears to be a $\mathrm{V}$-shaped rorl lying with its angle directed toward the centre of the wreath or monaster.

3. Metakinesis (Figs. 11, 12, 16).-In this phase of karyokinesis the chromosomes split along their axes into two exactly equal parts of similar shape, and these halves separate, each passing toward one of the attraction-spheres.

Meanwhile, the structure known as the achromatic spindle has been formed. 'This is a system of fibres resembling those that luave already been described as radiating from the polar bodies, but of even greater prominence. They are arranged to form a spindle with its apices at the polar bodies and its equator coincident with that of the cell and the plane of the monaster.

It is along the lines of this spindle that the chromosomes travel toward the centres of the attraction-spheres occupied by the polar bodics. 
FIG. 9.

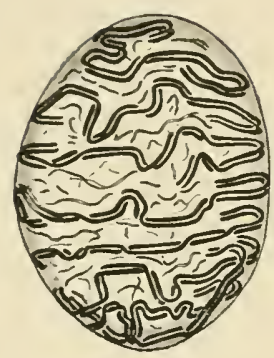

FIG. 11
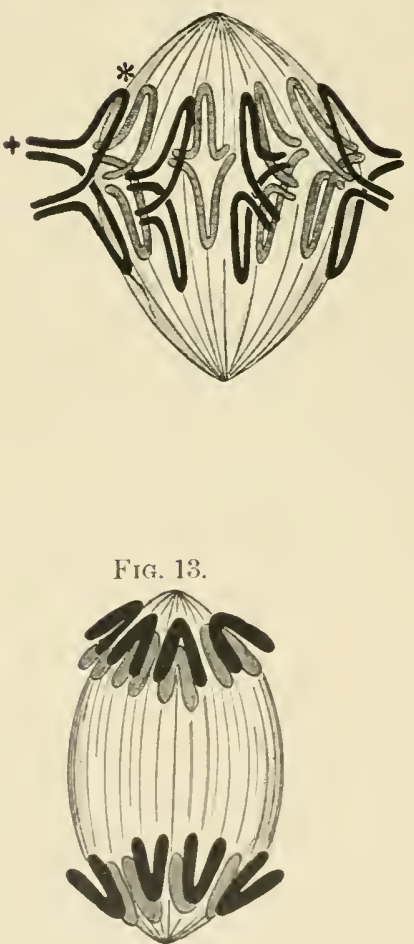

Fig. 10.

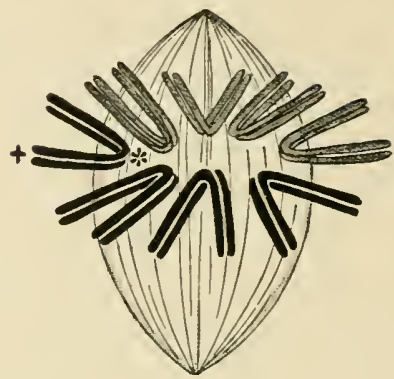

FIg. 12.

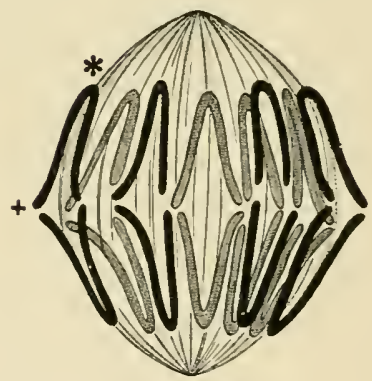

Fig. 14.

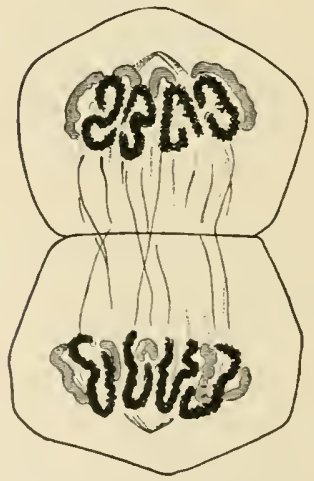

Diagrams illustrating the phases of karyokinesis. (Flemming.)

Fig. 9.-Spirem

Fig. 10.- Monaster

Fig. 11-Metakinesis, early stage.

Fig. 12.-Metakinesis, late stage.

Fig. 13.-Diuster.

Fig. 11.-Dispirem.

The aebromatic spindle is represented, but not the centrosomes (polar bodies). The cellbody is also omitted. 
The phases of karyokinesis that follow metakinesis are similar to those that preceded it, but ocenr in inverse order.

4. The Diaster Phase (Fig. 13).-The chromosome-, laving reached the attraction-spheres, group themselves aromd the polar body to form a wreath on a plane perpendicular to the axis joining the poles. These wreaths, with the achromatic spinclle, have an appearance somewhat resembling the letter $\mathrm{H}$, with a long cross-

FIG. 15 .

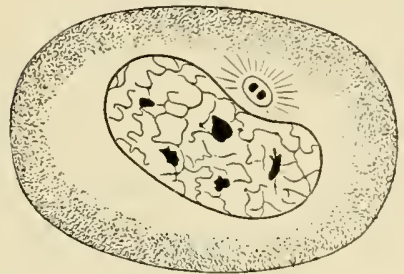

Fif. 16.

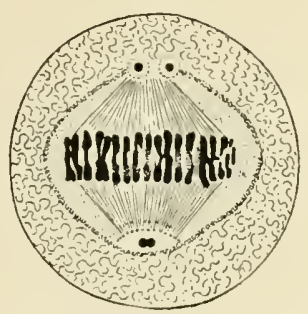

Karyokinetic figures in epithelial cells. From a carcinoma removed by operation. (Lustig and ralleotti.)

Fig. 15.-The centrosome has divided, but the nucleus is still in the resting condition. Five nucleoli are represented within the nucleus.

Fig. 16.-Metakinesis. The polar bodies have divided.

piece, formed by the spindle, remaining uncolored or only faintly tinged by nuclear dyes, while the uprights, made up of the chromosomes, are deeply stained.

The ends of the chromosomes now unite to form a thread, and the wreath-like arrangement gradually passes into that of the dispirem.

5. Dispirem (Figs. 14 and 17). - The halves of the original chromoplasm of the nucleus are now arranged in two skeins about the poles. From these the two daughter-muclei of the future cells are formed (Fig. 18).

During metakinesis the cytoplasm of the cell begins to show sigus of division. This may be aceomplished through a constrietion of the body of the cell, which gradually becomes deeper and finally severs the two portions; or a series of punctiform or short linear enlargements of the lines of the achromatic spindle appear in its equator, and throngh these a plane of cleavage, dividing the two new cells from each other, is finally established.

It is rarely that any biological process assumes sueh mathematieal precision as is displayed in karyokinesis. The purpose of that 
mole of cell-division appears to he an exactly equal partition of all parts of the chromoplatim between the young cells. Whether the amomint of cytoplasm given to the danghter-eells is the same or different, the division of the chromoplasm is exactly equal, not only in its whole bulk, but each chromosome, which appears to be the morphologieal unit of the ehromoplatsm, is split into exactly equivalent halves, one of which is contributed to the formation of each danghter-mucleus. It is for this reason that the chromoplasm is looked upon as the carrier of hereditary peculiarities.

FIf. 17.

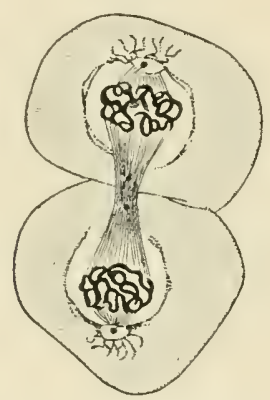

FIG. 18.

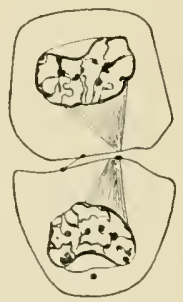

Fig. 17.-Dispirem. In this ease the polar bodies have not divided (compare Fig. 16i).

Fig. 18.-Daughter-nuclei which have nearly reached their full development. ('entrosomes present in the eytoplasm.

In these figures the structure of the cytoplasm is not given.

After the formation of the daughter-nuelei, the centrosome usually pasios from it into the eytoplasm. It may divide earlier than has been described, the division taking place while it exists as the polar body, or even carlier (Fig. 16).

$A$ cell nearly always divides to form two new cells, but sometimes there or more cells may be produced, the chromosomes being distributed among them (Fig. 19). Such eases are probably always morbid, and the resulting eells are not wholly the equivalents of the parent eell.

It ocelsionally lappens that the cytoplasm fails to divide after the formation of the daughter-muelei, and cells with two or more muclei result. When the nuelei continue to multiply and the eytoplasm increases in amount, but does not suffer division, large multintreleated colls are produred, which have been ealled "giantcell.." They necur normally in the marrow of bone and are proluced in many of the iuflammatory proceses.

The direct or amitotic method of cell-divicion is inaugurated by 
an active change in the shape of the nucleus, which may have previously increased in size and become richer in chromoplasm. The nucleus becomes constricted and finally separated into two portions,

FII. 19.

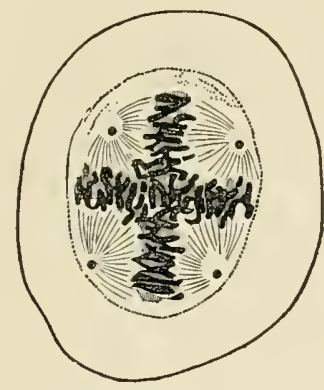

Epithelial cell from a carcinoma. (Galeotti.) The centrosome has divided into four portions, and the chromosomes are arranged with reference to these. The figure represents the metakinetic phase of karyokinesis, which will result in the formation of four imperfect nuclei.

which are not necessarily equally rich in chromoplasm. The eytoplasm, either at the same time or later, becomes similarly constricted until it is divided into two parts, each containing one of the nuclear divisions (Figs. 20, 21, 22).

FIG. 20

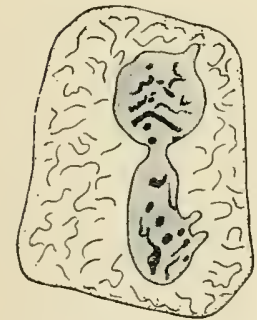

FIG. 21.

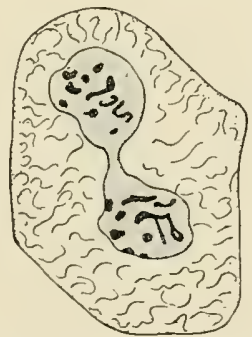

FIG. 2:.

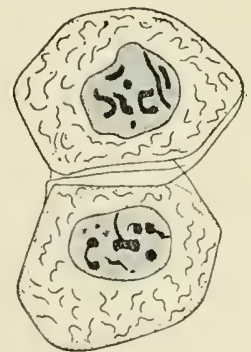

Amitotic cell-division. (Flemming.) Epithelial cells from the bladder of a salamander. Figs. 20 and 21 contain nuclei with eonstrictions dividing them into nearly equal portions. Fig. 22.-Contiguous cells, each containing a nucleus about half the size of those prevailing in the tissue, and, therefore, probably the result of eell-division by the direet proeess.

It is believed that this mode of division does not result in the formation of cells that have the complete character of the parentcell, and that their descendants form a degenerate race that is destined to extinction. It is quite obvious that no such precise partition of the chromatic substance is likely to take place as that 
which is characteristic of karyokinesis, and if the ehromosomes are really the earrier of hereditary peculiarities, this mode of division can hardly faror their perfect transmission.

The minute structures of the nuelens and cytoplasm deseribed have been studied in cells that were rapidly killed and then stained. In the living cells these details cannot be detected, and it is still uncertain whether they may not be in part due to the methods employed in their study. If the superficial layer of a frog's eornea be carefully stripped off' and placed upon a slide in a drop of the aqueons humor of the eye, covered with a cover-glass and then quickly observed, the nuclei of the cells may be seen as round and somewhat more highly refracting bodies than the surrounding cytoplasm. The nucleoli may also be made out, but the outlines of the individual cells and the internal differentiation of the nueleus eannot be seen. If the specimen be observed for a few minutes, there will come a moment at which the whole pieture ehanges. The nuclei suddenly become distinct; an intranuclear network appears and the cell outlines are more sharply defined. These ehanges may be hastened by plaeing a drop of acetic acid at the edge of the cover-glass. From this point the changes start and rapidly oceur in the adjacent cells until the whole speeimen is affeeted. It is as though the definite structures described in the foregoing parts of this chapter abruptly crystallized out of a nearly homogeneous medium. These changes probably mark the instant of death. The ehromosomes present in cells dividing by karyokinesis are visible in the living cells. The intranuclear network of resting cells is not visible during the life of the cell. It is not definitely known whether it and the minute structures of the eytoplasm, as seen in dead cells, existed in the living cells, or whether they were formed by a speeies of coagulation at the moment of death or were merely rendered more dense and therefore elearly visible. 


\section{CHAP'TER II.}

\section{THE ELEMENTARY TISSUES.}

The various parts of the body are composed of a small number of "elementary tissues." Each of these elementary tissues has a definite strueture, but the details of that strueture may vary within certain limits in different parts of the same mass or in different situations within the body. Such variations ean usually be referred to differences in the functional activity assigned to the tissue, which is not always exactly the same throughout the body. For example, epithelium is an elementary tissue consisting of eells which are nearly always rich in cytoplasm and are separated from each other by a very small amount of homogeneous intercellular substance. Wherever epithelium is found it has these general peenliarities of strueture. But the funetions demanded of epithelimm are of widely diverse character in different situations, and its strueture shows a eorresponding diversity in its details. The fact that it is made up almost exchusively of cells leads to the natural inference that the usefulness of epithelium depends upon cellular activities. Inasmuch as these may be of very different eharacter, we should expeet the tissue to vary ehiefly in the strueture and arrangement of its component cells aceording to the particular activity which was needed and the manner in which it was utilized. Such, as a matter of fact, is the case. These considerations will be made clearer if we follow a little more elosely the example offered by epithelium.

In some situations epithelium serves to protect the underlying tissues from injury. But the usual injurions influences which threaten the tissues differ in different parts of the body, and must, therefore, be averted by different means. Upon the surface of the skin they are chiefly of a mechanical or chemical nature, and to resist them the cells of the epithelium forming the epidermis undergo a modification in strueture, resulting in the formation of a superficial horny layer which is highly resistant to abrasion and chemical change. Upon the inner surfaces of the 
respiratory pas-ages the conditions are different. Here the tissues require protection from particles of dust that may be inhaled. For this purpose the epithelial cells lining those passages are provided with minute, hair-like proceses, "cilia," which execute lashing movements toward the outlets of the passages and occasion the transportation of substances coming into contact with them toward the onter world. In the digestive tract the conditions are again different. The tissues underlying the epithelial lining need protection from the chemical action of the fluids in the stomach and intestine, as well as from friction with their solid contents. The cells of the epithelium meet these needs by a secretion of mucus, which is discharged upon the inner surfaces of the digestive organs, where it serves as a protective layer and as a lubricant.

In other situations epithelium has an excretory function, which is less clearly of value in protecting its immediate surroundings, but is essential for the protection of the whole organism from substances which would exert an injurious effect if they were permitted to accumulate in the circulating fluids of the body. These substances are absorbed from those fluids by epithelial cells, from which they are clischarged from the body either unchanged or after transformation into other chemical componnds. Here the most obvious products of cellular activity are of no use in the economy, and are eliminated from it; but it is not improbable that the cells which separate them or their antecerlents from the circulating fluids may also discharge useful substances into those fluids ("internal secretion"). We must not assume that the most obvions function exereised by a tissue is the only service it does to the organism.

The epithelium which earries on this eliminative function is nearly always associated with other elementary tissues to form an organ, called a "cland," in which the epithelium is the functionally active tissue, the other tissues being subservient to it. The glands of the body differ considerably in both structure and function, but in all of thom it is epithclium which elaborates the materials essential to the formation of their normal secretions. Mention has already been male of those glands which furnish secretions charged with waste materials to be eliminated from the body. Such glands are alled excretory gatands, and are exemplified by the kidney. Other gland., distinguished as secretory in a restricted sense, fumish secretions which are of service to the organism. Examples of such glands are those which discharge their secretious into the alimentary 
tract where, by virtue of the ferments they contain, they prepare the food for absorption. Another example of a secretory gland is furnished by the sebaceons glands of the skin, which produce an oily substance serving to keep the epidermis upon which it is discharged soft and pliable.

In the secretory glands the cells of the functional epithelium elaborate within their bodies the substances necessary to give the glandular secretion its peculiar and useful characters. The-e substances accmmlate within the cells, where they are stored until required, when they are discharged into the secretion. While in the stored condition within the cells these substances may have a different chenical constitution from that which they aequire when they are discharged from the cells. A simple example of this chemical transformation is furnished by the liver, in the epithelial cells of which carbohydrates are stored as glyeogen, to be liberated as a closely related chemical substance, glueose. In like mamner the ferments stored in the epithelial cells of the digestive glands are not fully formed while in that situation, but exist in states known as "zymogens," from which the potent ferment appears to be readily formed when the cells are called upon to furnish it.

It is apparent, then, that the elementary tissue, "pithelium, cannot have the same microseopical structure in all the situations in which it is found ; but, notwithstanding these variations, wherever epithelium oceurs it presents certain general structural peculiarities which are constant and which distinguish it from the other elementary tissues. Similarly, each of the other elementary tissues presents variations in the details of its strueture in different situations, but always retains certain general structural characteristics distinguishing it from all the other elementary tissues. It is the first task of the student of histology to learn to recognize and identify these elementary tissues wherever they ocenr and however they may vary from the trpe which is first presented to him for study.

In the following chapters an attempt is made to give the student an idea of the essential structure of the elementary tisues, so that he may recognize them in specimens which he examines with the microscope. For this purpose they have been arranged in the order of their struetural simplicity.

When examining a specimen muter the microscope with a view to recognizing the elementary tissues it contains, the student shonkl habitually ask himself the following questions: (1) What are the 
general characters of the cells entering into the strueture of the tisue? (2) What kind of intercellular substances separates those cells? (3) How are the cells arranged with reference to each other and the intercellular substances? Correct answers to these three questions will cnable him to quickly determine the nature of the tissue he is observing, even if it should vary considerably in struetural details from examples of the same tissue with which he has already become familiar. 


\section{CHAPTER III.}

\section{THE EPITHELIAL 'TISSUES.'}

\section{ENDOTHELIUM.}

General Characters.-(1) The cells possess thin membranous bodies, exeept at the site of the nucleus, to enclose which the cell-body is thickened. (2) The intercellular substance is minimal in amount; clear and homogeneous in character. (3) The eclls are arranged, edge to edge, in a single layer. The wavy or denticulate edges of neighboring cells fit into each other, being separated by a mere line of the intercellular substance which in this tissue has received the name of "cement-substance" (Fig. 23). It appears probable that the connection between neighliboring cells is really much more intimate, and that what appears to be a homogencous cement-substance is in reality a fluid derived from the $1 \mathrm{ymph}$, and that the cells are conneeted with each other by exceedingly delicate cytoplasmic projections which join each other, the tissne fluid lying in the spaces between these eytoplasmic bridges. This arrangement is analogous to that described in connection with the prickle-cells which have for a long time been known to exist in the epidermis (see Stratified Epithelium).

Endothelium forms a thin membranous tissue composed almost exclusively of cells. It occurs in its most isolated form in the capillary bloodvessels, the walls of which are simply tubes of endothelium, supported extermally by the surrounding tissues and fluids and internally by the enclosed blood. It also covers the tissues surrounding the serous cavities of the body, where it serves both as a lining to the cavities and a smooth covering to the organs, dimin-

"The term "epithelial" is used here in its most inclusive sense to designate those tissues which cover surfaces, whether those surfaces are exposed to the outer world, as, for example, the skin and the mucous membranes, or are wholly enclosed, as are the inner surfaces of the bloodressels, lymphatics, and serous surfaces. Sometimes all these tissnes are called epithelium and the term endothelium is discarded. Other anthors use endothelium to designate only the cells lining the bloodressels and Jymphatics and similar cells occurring in connective tissue. The term endothelinm is retained here to distinguish cells derived from the mesublast, from the epithelium arising from the epilblast and lypoblast, and because there are morphologieal differences between these groups of tissues in the adult. 
ishing the friction resulting from their movements against each other. It does not ocenr in any situation where it would be exposed directly to the air.

The cells of enclothelium vary somewhat in size and shape. They may be polygonal, rhomboid, or stellate in form, and during life are

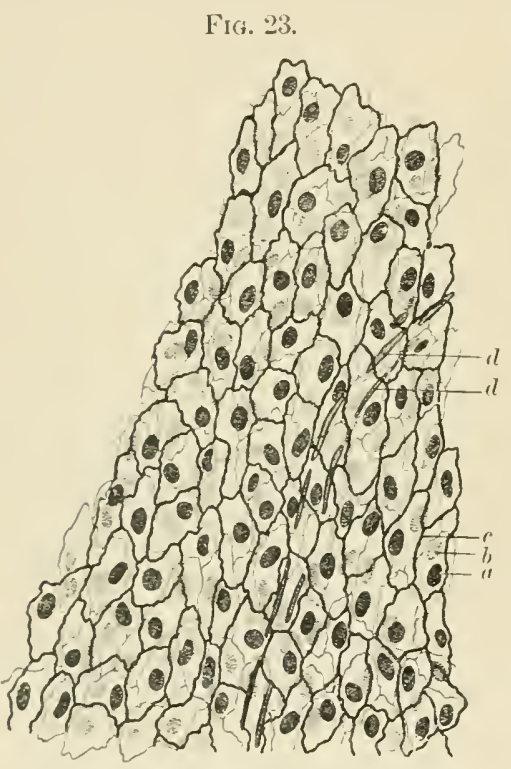

Iesentery of frog treated witl silver nitratc. The mesentery is covered on both surfaces with a layer of endothelium. Between these is areolar eonnective tissue containing bloodvessels, lymj,haties, and nerres. In this figure ouly the two endothelial layers and a cupillary blondvessel are represented: $a$, nucleus of endothelial rell belonging to uppermost layer; $b$, nucleus of ecll belonging to deep layer formind the lower surface of the specimen: $r$, intracellular cement between cells of upper layer of endothelium; $d, d$, nuclei of endothelial cells, forming a capillary blondressel. seen in profile. The bodies of these eclls are not reproducerl in the to distinguish it from that belonging to the ujper layer. figure. The rement in the reep layer of endothelium is representel by finer lines

soft and extensible so that their sizes maly be modified ly stretching or tension in one or more directions. The eell-bodics, or eytoplasm, are usually elear and apparently structureless or only slightly granular, but oceasionally some of the cells are smaller and more granular than the majority. This is especially marked in the cells surrounding minute apertures that are found here and there in the endothelial lining of the serous cavities (Fig. 24). These stomata furnish a direet communieation between the scrous eavities and the lymphatic spaces in the tissues surrounding them. These openings virtually convert the serons carities into enormons lymphspaces forming a part of the general lymphatie system.

The edges of entiguons endothelial cells are not everrwhere in equally elose approximation to each other (Fig. 25). The points where they are more widely separated than usual are ocenpied by an increased amount of the eement-substance, or procerses from cells in the underlying ti-sues are here interealated between the endothelial cells, reaching the surfice of the serous nembrane. In either ease these points of separation of the entothelial cells are not openings throngh the tissme, though they are spots where the tissue is relatively more 
pervious than elsewhere. They are called pseudostomata, to distinguish them from the stomata already mentioned.

FIG. 24.

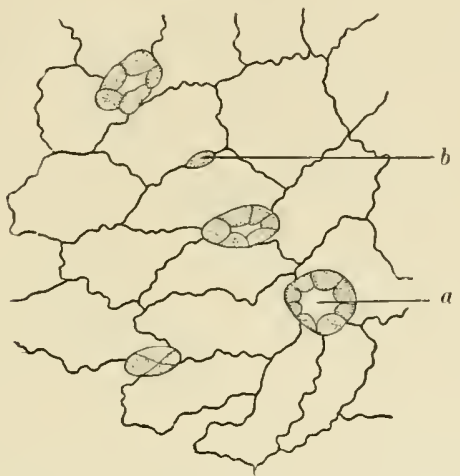

Endothelium on a serous surface of the frog. (Klein.) $a$, stoma bounded by endothelial cells with granular cytoplasm; $b$, pseudostoma. The nuclei of the cells are not represented.

The intereellular substance in endothelium is so small in amount and so homogeneous and transparent that it escapes observation

Fig. 25.

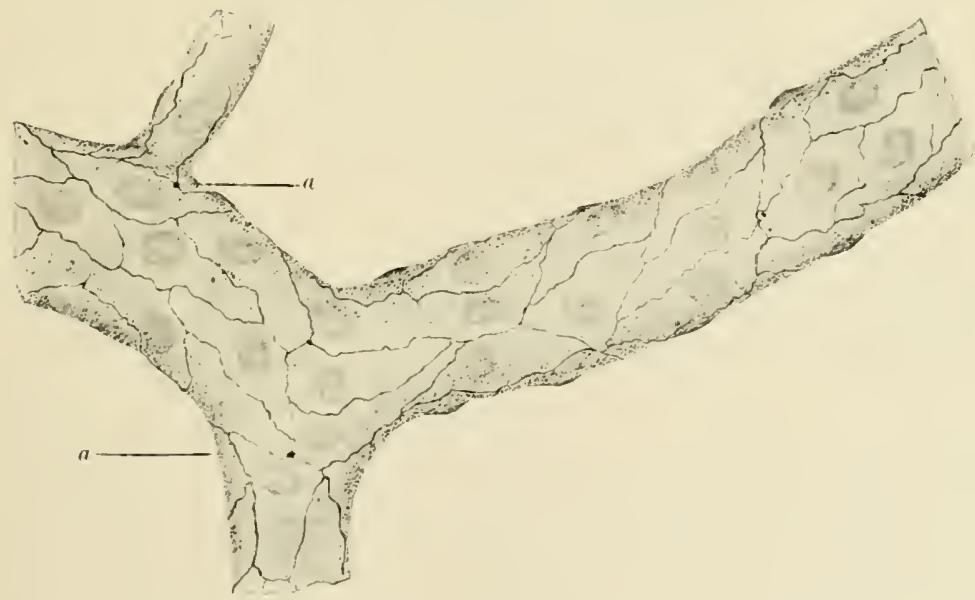

Endothelial lining of a small vein treated witl silver nitrate; dog. (Engelmann.) The figure represents a tube formed of endothelium the cells of which rary in size and shape. The whole wall of a capillary has essentially the same structure as this venous lining, but its calibre is smaller. The upper braneh in this figure may represent a capillary opening into the vein. $a, a$, pseudostomata occupied by cement-substance.

under the microscope unless special means are employed for its demonstration. The simplest of these consists in treating the fresh 
tissue with a 1 per cent. solution of nitrate of silver for a few moments, washing with distilled water, and then exposing it to the rays of the sum. During this treatment the intereellular substanee criters into combination with the silver. Upon exposme to strong light this componmel is clestroyed, leaving an insoluble black precipitate of silver oxide. When the specimen is exaninerl under the mieroseope, the site of the cement-substance is marked by the presence of this precipitate. Endothelimm so treated shows a network of tine dark lines, the meshes of which are oceupied by the cells of the tissue. When no such method hats been employed to render the intercellular substance conspicuons, the outlines of the cells cannot be distinguished, and the tissne appear's as a continnous, nearly homegencons membrane containing nuclei at more or less recular intervals. When seen in profile or vertical section, endothelimm appears as a delicate line, expanded at intervals to enclose a nuclens (Fig. 26). The nuclei of the endothelial cells are round or

FIG. 26.

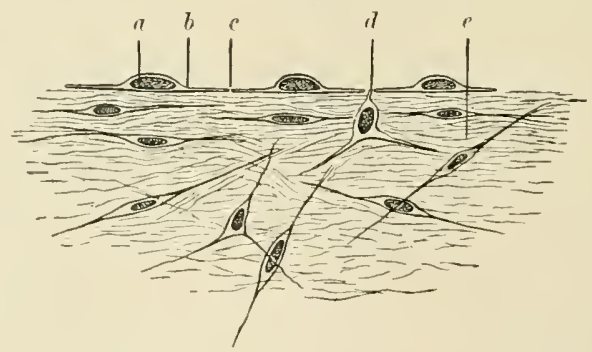

Diagram of vertical section through a serous membrane: $a$, nucleus of enrlothclial cell: $b$, body of ecll; $c$, line of junction betwecu two cells oceupied by cement-substance ; $d$, process of eonnective-tissuc cell occupying a portion of the intereellular suace between wo endothelial cells, one variety of pseudostoma; $e$, areolar tissue with fusiform and stellate cells. The vessels and nerves in the areolar tissue have been omitted.

oval, and each rell misully possesces lont a single melens situated near it: econtre, but ocearionally cells with two nuclei are observed. Functionally, endothelimm appears to play only a passive rôle in most sinations in which it is fouml. It furnishes a smooth covering for thowe intermal surfaces of the body which are exposed to frietion, ats, for example, in the serous eavities and the inner surfilces of the vaseular systems. In the capillary bloodvesticls and lymphaties condotheliom forms the entire wall of the vessels, and its thinness permits the passage of fluids through thow walls. The fact that the lymph in different parts of the body varies somewhat 
in composition has led to the inference that the endothelium of the appillary walls exereises an active function in determining what shall pass through it ; that the lymph is a sort of endothelial seeretion. It is difficult, however, to reconcile this view with the fact that the endothelial eells are so poor in eytoplasm. (See Lymph, 1. 120.)

Eudothelium is developed from the mesoderm.

\section{EPITHELIUM.}

General Characters.-(1) The cells are nearly always large and rich in granular cytoplasm. They contain distinet round or oval, vesicular nuclei, of which there is usually only one in each cell. (2) The intereellular substance is very small in amount and is elear and homogeneous. (3) The arrangement of the eells and their size and shape all vary greatly, giving rise to a number of varieties of epithelium, which are elassified according to the shape and arrangement of the cells. In pavement-epithelinm the cells are thin and arranged in a single layer, not unlike endothelium. In enbical epithelium the cells are thicker and also usually arranged in but a single layer. In columnar epithelium the cells are prismatic in form and rest with their bases upon the surface of the tissues beneath. They are usually separated at their bases by pyramidal eells, so that the layer of epithelium camnot be said to consist strietly of but one layer of eells, and in some situations there are several distinct layers. In stratified epithelium the cells are superimposed upon each other to form a layer of cells, the thiekness of which is severai times the diameter of a single cell. The cells of the variety of epithelium ealled ciliated epithelium differ from those of the other varieties in poscessing delicate, hair-like processes which project from the free surface of the tissue.

Epithelium resembles endothelium in being composed almost exclusively of cells separated by a minimal amount of intercellular substance. Like endothelium, it is nearly always found covering other tissues and having one free surface. The two tissnes differ greatly in the character of their cells, with one notable exception. This exeeption is found in the epithelial lining of the pulmonary alveoli, where the pavement-epithelimm contains cells that closely resemble those of endothelium. These cells are, however, direetly exposed to the inspired air, while endothelium is only found in situations where it is protected from all contact with the exterior.

1. Cubical Epithelium.-The cells of this variety of epithelium 
are approximately of the same diameter in all directions. They may be almost strietly cubical or spherieal, but are usually polyhedral as the result of mutual compression, their contiguous surfaces being flattened. They are nsually dieposed in a single layer upon at surface furnished by the underlying tissues, as, for example, in tubular or racemose glanks, but they may be aggregated to form a solicl mass of cells filling a sac, as in the sebaceous glands of the skin, or in strands or columns, varionsly disposed, as in the liver and suprarenal bodice.

It is this form of epithelinm that is chiefly concerned in performing the functions of seretion, and, for this reason, it is frequently designated as "glandular epithelium."

The appearanee of the individual eells varies considerably arecording to the functions that they perform and the stage of fmetional activity whieh ohtained at the time eellular changes were arrested when the particular specimen was prepared for study. It will suffice for present purposes of description to call attention to the fact that the eytoplasm is usually highly gramular, partly because of its own structure, partly becanse many of the substances elaborated and stored within the cells as the result of their functions appear in the form of gramules (metaplasm). The nature of these granules varies. They may be albuminoid, zymogenic gramules, or minute drops of fatty substances, which may coalesce to form distinct oily globules, or they may consist of earbohydrates, e.g., glycogen. The granular condition of the eytoplasm may be so marked

FIG. 27.

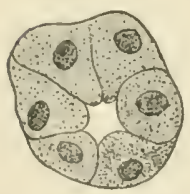

Fig. 28.

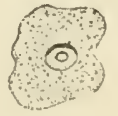

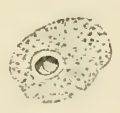

Cubical epithelium.
Fig. 29
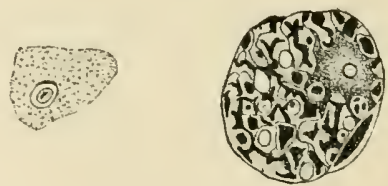

lig. 27. - Six cells from the sublingual gland of a man who was executed. (Sehiefferdecker.) Fig. 2Q. - Three isolaterl cells from the gastric tubules of the dog and eat. (Trinkler.)

Fig. 29.-Cell with higlly granular cytoplasm, the result of stored metaplasm, ehiefly gly. engen. (Barfurth.)

an to render the detection of the nuclens diffient in unstained speeimens (Figs. 27, 28, and 29).

In this form of epithelimm the presence of two nuclei in a single well is more frequent than in the other varieties. 
2. Pavement-epithelium.-This variety of epithelium consists of thin cells arranged edge to edge to form a single layer. With the exception of certain regions on the surfaces of the pulmonary alveoli, the cells are more eytoplasmic and granular than are those of enchthelium which this tissue in other respects closely resembles. During fotal life the smaller air-passages and alveoli of the lung are lined by a parement-epithelimm, the cells of which are nearly as thick as those of some varieties of eubical epithelimm. When, however, the lung is expanded by the respiratory acts following birth, many of the cells lining the alveoli become greatly extended and flattened mutil their bodies are thin and membranous and their melei inconspicuous or eren destroyed (Fig. 30). These greatly flattened epithelial cells are found covering those portions of the

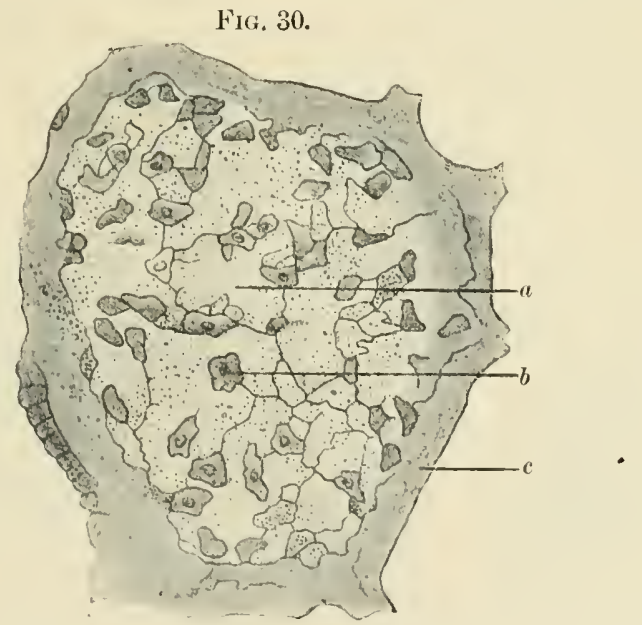

lavement-epithelium. Surface view of the lining of a pulmonary alveolus; man. (Kölliker.) $a$, membranous cell without a nueleus; $b$, nucleated granular cell; $c$, cut surface of the vertical wall of the alveolus, the structure of which is not represented.

alveolar walls in which the eapillary hloodvessels are situated and permit a rady interehange of gasos between the air in the alveolar eavities and the blood circulating in their walls. Many of the epithelial aclls covering the tissues in the meshes between the capillaries retain the eytoplasmie and granular character possessed before birth and appear eapable of multiplying and, perlaps, replacing such of the thimner eells as maly be thrown off or destroyed.

It will be evident, from the foregoing deseriptions, that there 
is no sharp structural line separating eubieal from parement-epithelium. Functionally, pavenentepithelium in a much less active tisicue than the enbical varietr.

3. Columnar Epithelium (Figw. 31, 32, 3:3).-The cells of this FIr. 31

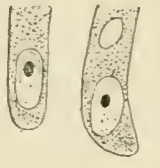

(I

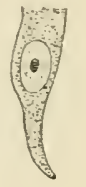

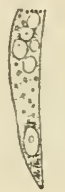

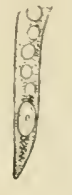

b

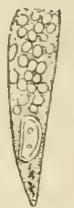

Columnar epithelium. From tongne of pscudopus. (Seiler.) a, three cells with intact cytoplasm, except the central one, which contains a vacuole; $b$, three cells of which the distal euds contain drops of fluid (vacuoles) or of metaplasm.

form of epithelium are of a general columnar or prismatic shape and posicss a single nucleus and a cytoplasm that is nsually distinetly granular. They are arranged with their long axes parallel to each other, so that their free ends form the surface of the epithe-

FIG. 32.

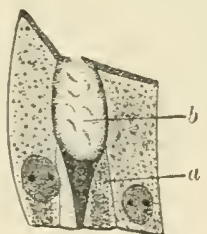

FIG. 33.

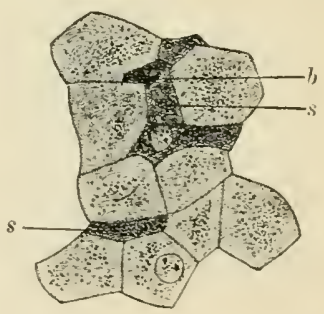

Columnar epithelium.

Fig. 32.-From small intestine of the mouse. (Paueth.) a, pyramidal reserve cell, nucleus not included in section; $b$, "goblet" cell, enclosing a large drop of secretion.

Fig. 33.-From small intestine of the mouse. (Paneth.) (olumnar epithelial cells seen from above: $b$, goblet-cell, the mucums contents darkened by the hardening process; $s, s$, highly granular cells which have recently dischargell their secretion.

lium, while their derper ends either rest upon the tis-sues beneath the epithelimu or upon other epithelial cells of different shape which form one or more laver: between the columnar eells and the

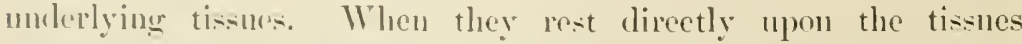
beneath there are 11-1ally other epithelial cells of a prramidal or oral shape which may be regarded as immature eells ready to take the place of such fully developed eells as may become detached or destroyed. The presence of these cells oceasions a narrowing of 
the deep ends of the columuar cells, so that they are not strictly. prismatic in form. In cross-section, or when viewed in a rirection parallel to their long axes, the cells have a polygonal form due to the lateral pressure they exert upon each other (Fig. 3:3).

The nuclei of the colummar cells are oval, situated nearer the base of the cell than its superficial end with their long axes parallel to those of the cells themselves, and are resicular in structure with a rlistinctly reticular arangement of the chromatin filaments.

Columnar epithelium is found chicfly upon the frce surfaces of mucons membranes, but also occurs in some of the secreting glands. The minute structure of the cells varies somewhat in different situations, but the consideration of these minntixe must be deferred until a description of the structure of the lifferent organs is undertaken in a subsequent chapter.

4. Ciliated Epithelium (Figs. 34, 35, 36).-Ciliated epithelium

FIG. 34.

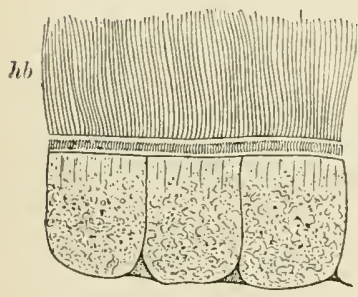

FI(.. 35.

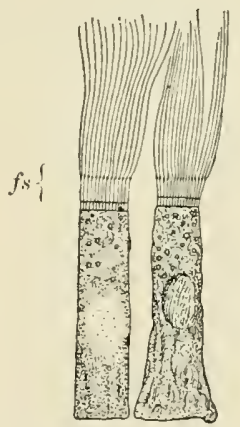

Fig. 36.

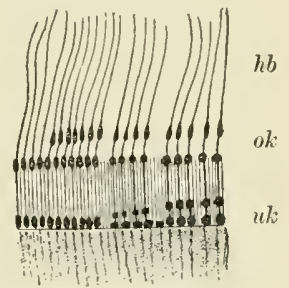

Ciliated epithelium. (Frenzel.)

Fig. 34.-Cubical cells with long cilia $(h b)$. The nuclei of the cells are obscured by the granular eytoplasm.

Fig. 35.-Columuar ceils. The rodded margin, $f s$, eorresponds to the cutiele in Fig. 37 .

Fig. 36.-Diagram illustrating variations in the structure of the eiliated ends of cells. The rodded portion, ok to $u k$, corresponds to the cuticle of other varieties of epithelium, though the latter do not possess the knobbed ends of the rods represented in this figure; $h b$, cilia.

is merely a variety of either colmmnar or cubical epithelinm in which the free ends of the eells are beset with delicate hair-like processes, which execute lashing movements in some one direction. It is found lining the trachea and bronchi, the cilia here serving to propel toward the laryux such particles of dust as are brought into the respiratory passages by the currents of air during respiration. Ciliated epithelium also occurs on the lining membranes of the nose 
and the adjoining bony arities, the nueous membrane of the uterus and the Fallopian tubes, the vasa efferentia of the testis and a part of the epirlidymus, the ventricles of the brain (except the fifth), the central canal of the spinal cord, and the duets of some glands.

The puscesion of eilia, which are very motile organs, presents a marked reparture in specialization from the usual metabolie functions of epithelium. Ciliated cpithelium rarely exercises a secretory function, its stock of energy being utilized to produce motion instead of chemical change. But there are sccreting varieties of epithelium possessing a "cuticle" which appears to be morphologically analogous to the cilia, but in which the fibrils are less highly developed, probably not motile, and, therefore, functionally not the equira-

Fig. 37.

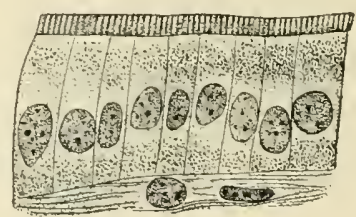

Cuticularized epithelium, intestine of dog. (Paneth.) Rodded cuticle of the free ends of columnar cells. In most specimens of eiliated epithelium from human tissues, where no speeial care has been taken to preserve the eilia, the eiliated border presents the appear* ances shown in Fig. 37.

lents of cilia. This cuticle is highly developed in the cells covering the mueons membrane of the intestine (Fig. 37).

5. Stratified Epithelium.-In the varieties of epithelium hitherto enniclered the cells are, in the main, disposed npon some surface in a single layer, some, at least, of the eells nsually extending from the bottom of the laryere to its surface.

stratified ppithelium is distingushed from these by being of greater depth and consisting of several layers of cells. The epithelimm lining the check or the nesphagns may be taken as a typical (xample of this variety.

The most decply situated cells are -mall and nearly filled by the round or oval nuclens. They undergo frequent division, and as they multiply some of them are cowded toward the surface. For at time tlese inerease in size througle a wowth of their eytoplasm. But at they are pushed nearer to the surface and farther from the somres of mutrition in the vasular tismes molerlying the epithelimm, they hecome flattened and their bodies lose their eytoplasmic character, being converted into a lly, horny substance, keratin. 
Upon the free surface they are redueed to thin scales, closely adhering to each other and their subjaeent neighbors, but entirely devoid of both eytoplasm and nueleus (Fig. 38).

Stratified epithelium is found upon surfaces exposed to friction, which it serves to protect against mechanieal injury, and, in some

Fig. 38.

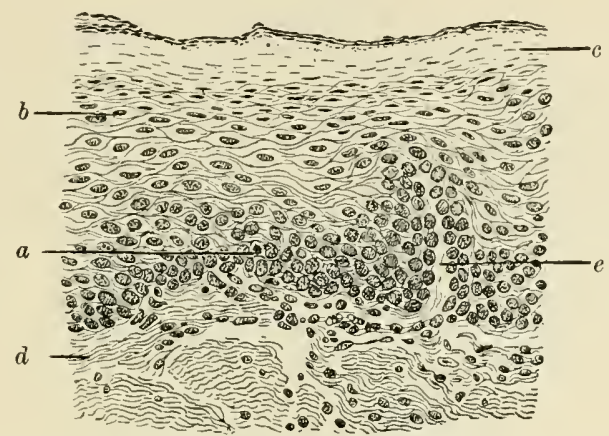

Stratified epithelium, cesophagus of the rabbit: $a$, karyokinetic figure in a cell of the deep layer, demonstrating the fact that the cells multiply in this region; $b$, larger flattened cell nearer the surface; $c$, horny layer made up of cells that have undergone keratoid degeneration; $d$, underlying fibrous tissue. In one place, near the centre of the figure, six blood-corpuscles reveal the presence of a small vessel; $e$, tangential section of a small fibrous papilla extending into the epithelium and surrounded by young epithelial cells.

cases, against desiccation. It forms the epidermis of the skin, and lines the month, cesoplagus, rectum, and vagina. In these situations the scaly or squamous cells of the surface are constantly being removed by the attrition to which they are exposed, but are as constantly replaced by fresh cells from the deeper layers of the epithelium. Pressure and moderate friction stimulate the multiplication of the cells in the deepest layers of the tissue, so that parts, $e . g$. of the skin which are especially subjected to such influences acquire a thicker epidermis (callus).

Where the stratified epithelium consists of many layers of cells, as is the case, for instance, upon the skin, there is a provision for the nourishment of the growing cells which are somewhat removed from the vascularized subjacent tissues. The cells of the deeper laycrs are somewhat separated from each other, leaving a space between them through which nutrient fluids ean circulate. Across this space numerous minute projections or "prickles," springing from neighboring cells, join each other, forming connecting bridges between the cells. When isolated, such cells appear covered with these small spicules ("prickle-cells"), and their presence probably 
increases the tenacity with which the cell-remains adhere to each other when they become hardenerl and tonghened on the surface of the epithelial layer (Fig. 393).

These delieate bridges comnecting neighloring eells are not peeulian to stratified epithelium, though they are more comspienons in that ti-we than clsewluere. They have been observed between the cells of the columnar epithelinu of the intestinal mueous membrane, and also between the cells of other elementary tissues; e. $g$., smonth musenlar tissue.

6. Transitional Epithelium (Figs. 40 and 41).-This variety resembles stratified epithelium in forming layers several cells in thick-

FI(i. 39.

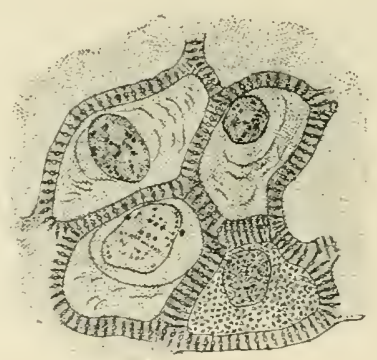

Pricklecells from human stratified ejithelium. (Rabl.) Four cells with delicate processes uniting across an interveningspace are represented. The lower right-hand cell is just below the upper surface of thesection, so that its surface is secn. This is covered with minute spots, which are end views of the prickles directed toward the observer. The nucleus of this cell is not in sharp focus, a fact indicated by the fainter outline in the figure.

ness, but differs in the character of its superficial eells. These do not undergo the horny ehange peculiar to stratified epithelium, but continte to increase in size, forming a covering of very large cells lying upon those beneath. Under these largest superficial cells are priform ealls lying with their larger, rounded ends next to the topmost layer, while their deeper and more attemated ends lie between the oval or romul cells that form the one or two deepest layers of the epithelinm and rest upon the molerlying tisisnes.

Transitional epithelimm is found lining the renal pelves, ureters, and bladker. Its structure permits of a considerable stretehing of the tisurs beneath without rupture of the epithelial laver over them, the cells of which heeome flattened to eover the inereased surface, to roturn to their first ondition when the viscus which they line is emptied. This is notably the care in the bladeler, the epi- 
thelial lining of which may be taken as a type of this variety of tissue.

The functional activities of epithelium are in marked contrast to the comparatively inert character of endothelium. The eytoplasmie Fig. 40.

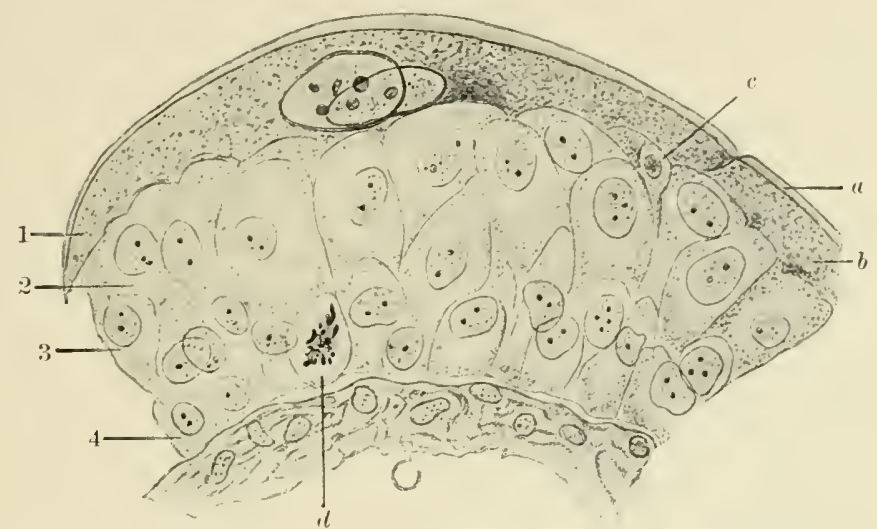

Transitional epithelium from blarlder of the mouse. (vogiel.) 1,2,3, and 4 indicate the layers of eells, not everywhere equally well defined. $a$, hyaloplasmie surface, and, $b$, cytoplasmic body of large superficial cell; $c$, leucocyte-i. $e$, white blood-eorpusele that has wandered into the epithelium l,y virtue of its amceboid movements; $d$, karyokinetic figure in a cell belonging to the deepest layer. Beneath this layer is the fibrous tissue, which is covered by the epithelium and forms a part of the wall of the bladier. The superfieial cell, which is fully represented, contains two nuclei, a not very infrequent occurrence in these cells.

nature of the epithelial cell, when contrasted with the poverty in cytoplasm of the cell in endothelium, would lead us to expect this difference in the cellular activities of the two tissues. At the beginning of this chapter a sketch of the manifold functions of epithe-

FIri, 41.
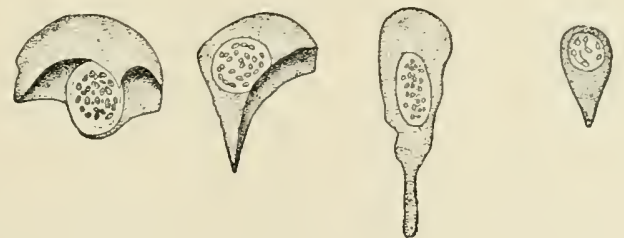

Transitional epithelium. lsolated cells from the bladder of the frog. (List.)

linm was given. It is a fair general statement of its nsefulness to say that epithelium is chiefly concerned in bringing about chemical clianges in substances bronght to it. Sometimes these substances are elaborated into fresh cell-constituents, and the activity of the 
tissue is displayed ehiefly in an active multiplication and growth of its eclls. This is especially true in the stratified variety, where protection is provided by a constantly renewed supply of cells. In other cascs the substances received by the cells are claborated into definite componds destined to form the essential constituents of a secretion. This secretory function of epithelium is an extremely important one, and for its performance that tissue is nsually arranged in a special structure or organ, called a gland. A brief statement of the general characters and classification of these organs may here appropriately find a place.

Secreting Glands.-The simplest type of secreting structure consists of a surface covered with a layer of epithelium, the cells of which are endowed with the power of elaborating a secretion and discharging it upon their frec surfaces (Fig. 32, b). The tissues supporting the epithelium belong to the comnective tissues, and are fibrons in character and well provided with bloodvessels, lymphatics, and nerves. These bring to the epithelium the substances necessary for its nourishment and work, and place its activities under the control of the nervous system. Between the epithelimm and the fibrous tissue supporting it there is frequently a thin membranous layer of tissue that often appears quite homogeneous, evidently belongs to the comnective tissne;, and has recived the name of "basement-membrane." This appears to offer a smooth surface for the attachment of the epithelial cells, which receive their nourishing fluids through it.

The epithelial surfaces of many of the mucons membranes are examples of the formoing simple secreting structure. The secretory function is here of nse as an adjunct to the protective function ancigned to the epithelial covering, and the quantity of secretion is but slight under nomal eomlitions. Where the volume of secretion recuired is considerable some provision for an incrase in the extent of soreting surface is necescary. This may be aceomplis led hy an invagination of that surfice, which then forms the lining of one or more tubes or sac's, into which the secretion furnished by the eprithelial rells is dircharged. Such an arrangenent of the tissues constitutes a glend, and it is evident that these may be arranged into groups or clatices arcording to whether the secreting surfice formi a single tuhe or sar, or several such tubes or sacs, uniting to form a single gland. Thus, there may be simple or compond tubular gland-, or simple or compoumd sacerular glands. Whether the deeper portion of the ghand have a tubular or saccular structure, the secre- 
tion of the gland is discharged upon some free surface through a tubnlar outlet, called the duct. This is freqnently lined with a nonsecreting layer of epithelial cells differing in character from the aetively secreting epithelium in the deeper portions of the glandular passages (Figs. 42-47).

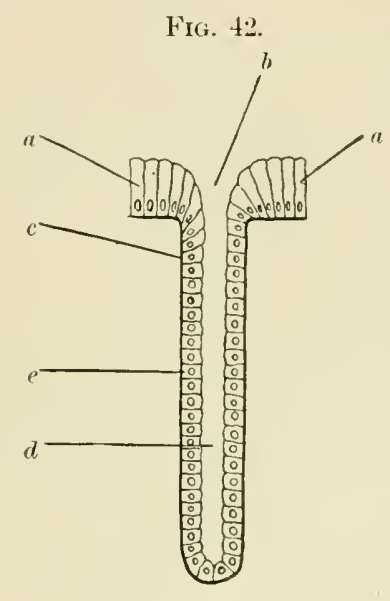

FIg. 44 .

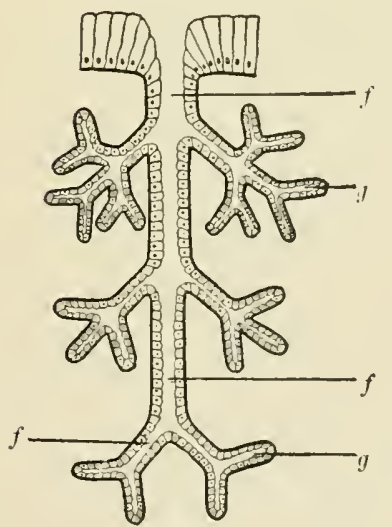

FIG. 43.

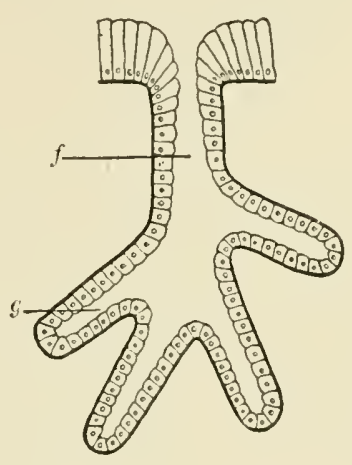

Fig. 45 .

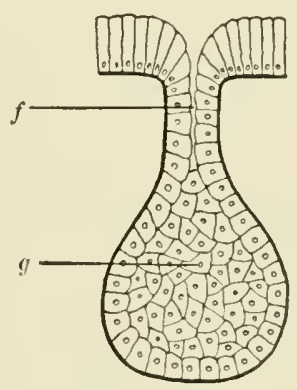

Diagrams representing various types of gland.

Fig. 42.-Simple tubular gland: $a$, epithelium covering the surface on which the secretion is discharged; $b$, mouth of gland; $c$, epithelium lining the duct. This gradually passes into the secreting epithelium. Some simple tubular glands have no such distinction between the cells near the mouth and those nearer the fundus, but all the cells are of the secreting variety-i.e., exercise that function. $e$, secretory epithelium; $d$, lumen. The sweat-glands are simple tubular glands which are coiled in their lower part to form a globular mass.

Fig. 43.-Compound tubular gland : $f$, duct : $g$, acinus.

Fig. 41.- Racemose tubular gland : $f, f, f$, ducts: $g, g$, acini.

Fig. 15.-Simple saccular gland: $f$, duct; $g$, acinus. 
FI(i. 46.

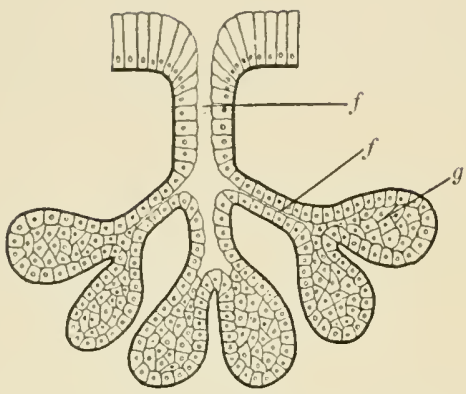

FIs: 47.

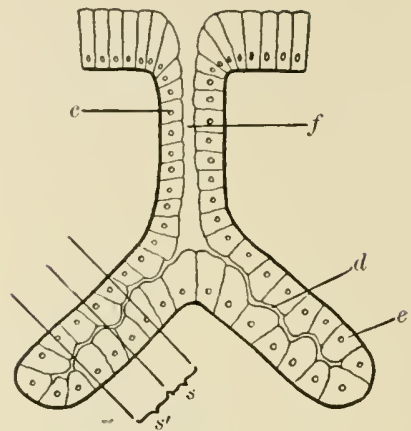

1)iagrams representing various types of gland.

Fig. 46.-Tiacemose saccular gland : $f, f$, ducts; $g$, acinus.

Fig. 47.-Compound tubular gland, with a marked distinction in the character of the epithelium in the duct and acini : $c$, duet elithelium : $f$, duct; $d$, lumen of the acinus; $e$, secreting epithelium. This type of gland is common. This figure is introduced to show how difficult it might be to detect the lumen of the acinus in sections of such a gland. The lumen is of very small diameter (its size is exaggerated in this diagram) and runs such a tortuons conrse among the enithelial cells that even perfect cross-sections of the aeinus might fuil to reveal it if it happened at that point to run obliquely to the axis of the acinus. It would then appear merely as a small clear spot upon the granular cytoplasm of the cell that lay immediately beneath it. $s, s^{\prime}$, remresent the way in which two such sections would contain portions of the acinus. The lumen in $s^{\prime}$ would be more easily detected than in $s$, berause its gencral direction is more rectilinear and more nearly coincident with the line of vision.

It is rarely posible to trace the connection between the duets and other portions of a gland in sections, for the axes of these different parts seldom lie in one plane. As a result of this cireumstance, sections of grands usually present a collection of round or oval sections of tubes or sacs, which are lined with a single layer of epithelial ectls, surromding a lumen. The cells in the deeper portions are nstally grammlar and enhieal; those lining the duets are zenerally more colmmur in shape and less gramular in character. 'The deeper portions are alled the alveoli or acini of the gland, to distinguish them from the ducts, and the chanacter of the epithelimm they contain differs accorling to the function of the gland. Sometimes the cells are so lange that they nealy fill the acini, leaving a seareely preceptible lumen. In other glands the eells are less volmminous and the lumen of each acinns is distinet. It orousionally happens, ค.\%, in the smbmaxilary glands, that the acini contain two sorts of cells which secorete different materials. Both kinds of cell may be present in the same aciuns, or each kind may be confined to different arini. In sturlying sections of grands it must be horne in mind that the tangential section of an acims would alppear as a group of 
cells surrounded by fibrous tissue, with no trace of a lumen among the epithelial cells (Fig. 48).

Glands develop from surfaces which are covered by epithelium.

FIf. 48.

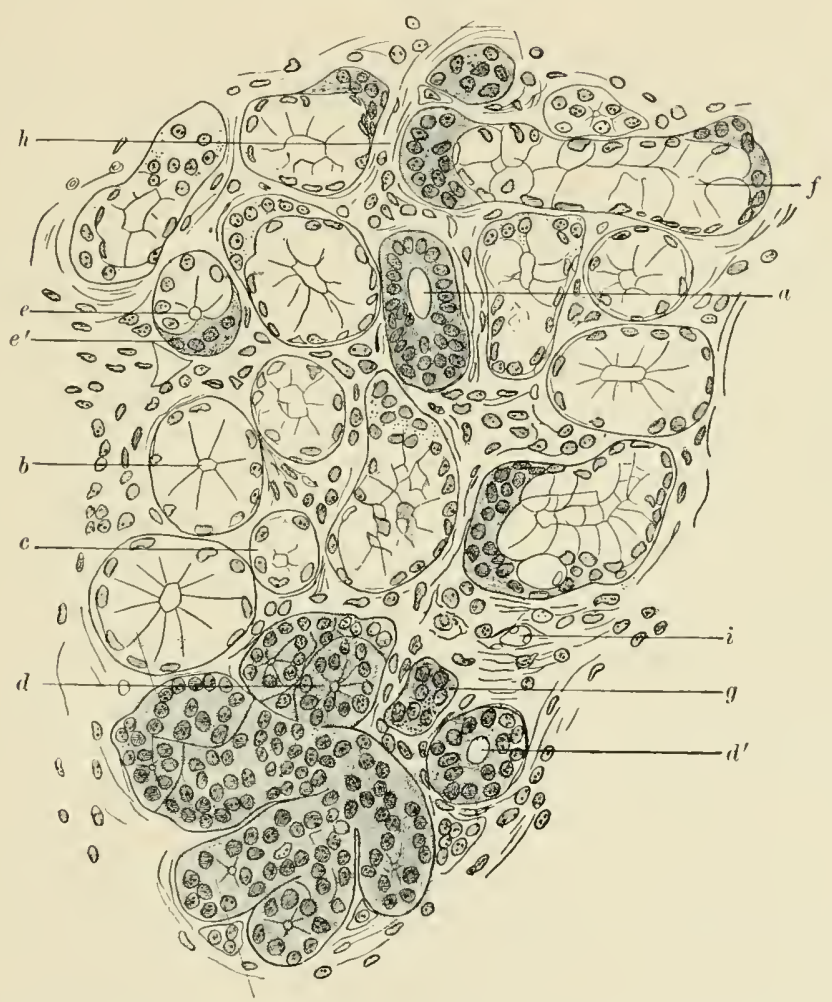

Section of gland from human lip. (Nadler.) $a$, duct, eut in slightly oblique direction (lumen oval), and probably near a branch, which would aceount for the apparent thickness of its epithelial lining in the lower half; $b$, cross-section of acinus secreting mucus ; $c$, tangential section of a similar acinus near its extremity and beyond the end of the lumen. r'ross-sections of the cells at the fundus oceupy the centre, $d$, cross-section of an acinus secreting a serous fluid, revealing a small lumen; $d$ ', a similar acinus with a larger lumen, probably eut near its junction with a duct; $e$, acinus with crescentic group of cells with granular eytoplasm $\left(e^{\prime}\right)$, and other cells like those in $b$. The granular cells of small size are considered to be cells which have discharged their secretion and are accumulating material for a fresh supply. $f$, nearly axial longitudinal section of a portion of a mucous acinus : $g$, tangential section of a serous acinus; $h$, fibrous connective tissue between the arini; $i$, capillary bloor ressel in the fibrous tissue.

The eells of this epithelimm multiply and penetrate into the underlying tissues, forming little solid tongnes or columns of cells(Fig. 181). If the gland is destined to be of the simple tubular variety, this eolumn of eells then becomes hollowed to form the lumen, the cells being 
arranged in a single laver lining the tubule. If the gland is to be compound, the solid column of eells branches within the tissues, and then the lumina of the different portions are formed, the epithelimm in the different parts beeoming differentiated als specialization of function develops.

The foregoing general description of the structure of secreting glands applies to those glands which have a purely secretory funetion, discharging the products of their activities upon some free surface, such at the skin or a mueous membrane. There are other glandular organs which perform more complicated functions and the strueture of which deviates from that of the simpler glands. Examples of these are furnished by the liver and kidney, the struetures of which must be deferred to a subsequent ehapter. Other exeeptions are exemplified in the thyroid body and other "ductless" glands, which diseharge no seeretion into a viseus or upon a free surfice, but which have an alveolar structure similar to an ordinary secreting gland. These alveoli do not communicate with ducts, whieh are wanting; but whatever products they may contribute to the whole organism are apparently discharged into the circulating fluids of the body by a process of absorption similar to that through which the glandular epithelium obtains its materials from those fluids, or by a direet diseharge into the lymphaties. (See (hapter on Ductless glands.) This process is indicated by the term "internal seeretion," and is probably of commoner oceurrence than is usually supposed. In faet, it but represents a special interpretation of the phenomena of interehange of material that is eonstantly going on between all the cells of the body and its cireulating fluids.

Epithelinm is developed from the epiderm or hypoderm; never from the mesoderm. In this respect, as well as in its functional rôle, it diffọrs from endothelium. 


\section{CHAP'TER IV.}

\section{THẸ CONNECTIVE TISSUES.}

THE two varieties of elementary tissue that have just been considered-namely, endothelium and epithelium-owe their qualitics directly to the eharacters of the cells that enter into their composition. The intercellular substances are insignificant in amount and subordinate in function.

In marked contrast to these are the tissues composing the group known as the "connective tissues." Here the usefulness of the tissues depends upon the character of the intereellular substances which confer upon the tissnes their physical properties. The activities of the cells entering into the composition of these tissues appeatr to be confined to the production of those important intercellular substances and the maintenance of their integrity. The cells may, therefore, be considered as of secondary importance in determining the immediate usefulness of the tissnes, the first place being given to the intercellular substances. As was stated in the introductory chapter, these connective tissues are essentially passive -i.e., they are useful because of their physical characters rather than becanse of any ability to transform either matter or energy. Where the ability to accomplish those transformations is of importance the tissues are foum to be essentially cellular in charaeter, as we have already seen to be the case in the epithelial tissues.

The connective tissues may be divided into three main groups: the cartilages, bone, and the fibrons tissues. Each of these groups has certain general struetural characters that di.tinguish it from the other elementary tissues, but within each group there are varieties which differ ennsiderably in the detailed character of their intercellular substances and in the arrangement of these with respect to the cells.

All the elementary tissues belonging to the connective-tissue gronp are developed from the mesolerm. 


\section{THE CARTILAGES.}

General Characters.-(1) The typieal cell of eartilage is round or oval in shape, rich in eytoplasm, and possesses one (rarely two) nuclens of oval form and vesicular and reticulated structure. Within the cytoplasm there are frequently one or more clear spots, which are drops of homogeneous fluid, "vacuoles." The cells frequently depart somewhat from this type. Where the tissue is growing they are usially flattened on the sides turned toward their nearest neighbors. This is because they are the offepring of a cell that has reently divided, and are as yet separated by only a small amount of intercellular substance. Under these circumstances each cell is frequently surromed by a thin layer of intercellular substance, probably of relatively recent formation, which differs a little from that further from the cell and gives an appearance as thongh the cell were enclosed in a eapsule. With some dyes this recently formed intercellular mbstance receives a somewlat different color from that of the older intercellular substance. In older cartilage this difference is no longer evident. Where cartilage is being replaced by

FIG. 49.

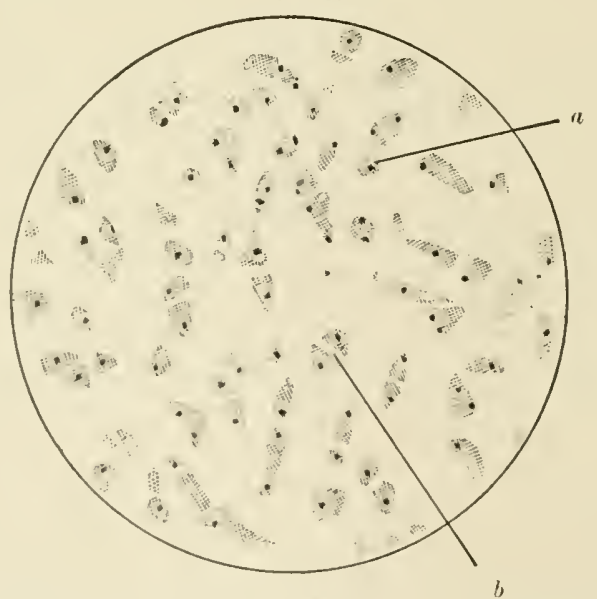

Hyaline eartilage. Scetion of human costal cartilage: $a$, nearly spherieal eell eontaining two vacuoles; $b$, reeently formed intercellular substanee (" matrix"), separating two cells that have been produced by the division of a single cell. There are several other cxamples of a similar grouping of cells, due to the same cause, in the figure. Between the cells is the hyaline, nearly" struetureless "matrix."

bone, "s-ifieation," the cells are arranged in columns, with only a small amount of intervening intercellular substance, and have a general cubical form. 
(2) The intercellular substance is abundant in amount and has received the special designation "matrix." Aceording to the eharacter of this matrix, the cartilages have been divided into three varieties: hyaline cartilage, fibro-eartilage, and clastic cartilage. In hyaline eartilage the matrix is elear and homogeneous and has the consisteney of gristle. In fibro-cartilage it is traversed by or nearly wholly composed of delieate fibres similar to those of white fibruus tissne, which will be deseribed presently. In elastic cartilage the matrix contains coarse, branching, and anastomosing fibres similar to those of elastic fibrous tissue (vide infra).

(3) The arrangement of the cells and intercellular snbstances varies considerably. Sometimes the cells are pretty uniformly distributed throughout the intercellular substance. Sometimes they

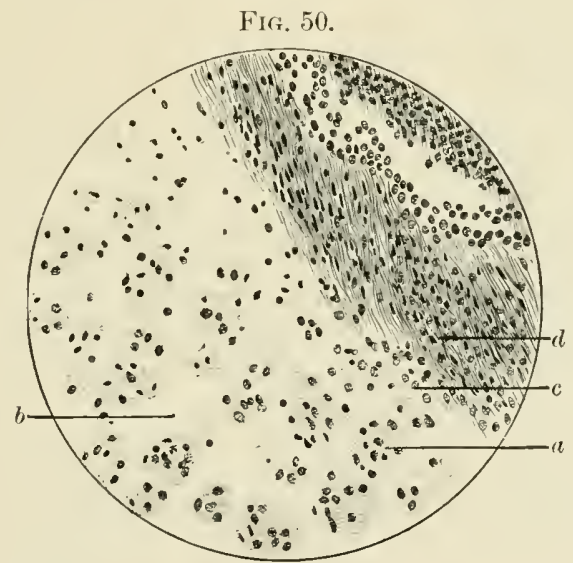

Hyaline cartilage and perichondrium. Iluman costal cartilage. Same specimen as Fig. 49 . $a$, group of cells formed by division, but not yet separated by matrix ; $b$, matrix ; $c$, cells with a comparatively slight amount of eytoplasm, marking the transition from cartilage to fibrous tissue ; $d$, perichondrium, composed of fibrous tissue (spindle-shaped cells with a fibrous intercellular substance).

are arranged in groups of from two to four or even six cells. Toward the surface of a piece of eartilage the cells are apt to be smaller than those nearer the centre, and are frequently flattened. Here, also, they often lose the eharacters that distinguish them in the body of the tissue, and more and more closely resemble the cells of the fibrous tissue surrounding the eartilage. This fibrous tissue is called the "periehondrium," and is usually not sharply defined from the cartilage itself, the matrix of the latter becoming more and more fibrons in character and the cells less distinctly like those 
FIG. 51 .

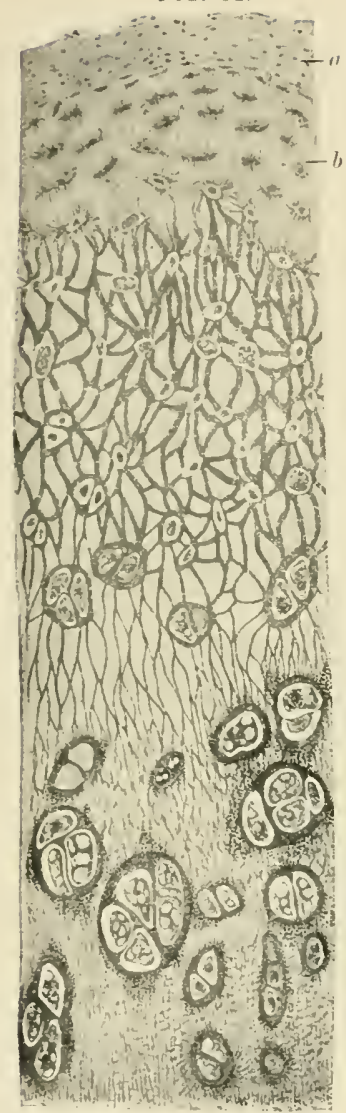

Hyaline eartilage. Section from luman thyroid eartilage (Wolters.) a, perichondrium: $b$, peripheral zone of cartilage with hattened cells. In the deeper portions of the eartilage the eells are larger, are arringed in groups, and are surrounder] by reeently firmed matrix. The cells in the derepest prortions of the cartilage are vacuolater, andl about the groups of eells are fine granules of lime salts. In the matrix are numerous ana-tomosing lines, whirh are interpreted as fine ranals, serving (1) carry nourishment to the eclls in the cartilage.

tion some of the cells typical of eartilage mutil the distinction hetween the two tissues is lost. The periehondrim is wanting over the free surfaces of the articular cartilages.

1. Hyaline Cartilage (Figs. 49, 50, and 51).-Althongh under ordinary powers of the microscope and in specimens which have not been specially prepared the matrix of hyaline cartilage appears clear and almost, if not quite, homogencons, closer study reveals the presence of a fine network within the clear intercellular substance. This network is thought to be a system of minute chammels through which the mutrient fuids permeate the ti-sne and reach its colls. It may be, however, that this reticulum is of fibrons character, in which ase the fibres might be more pervious than the surrounding matrix, and bear the same relations to the nutrition of the tissue as a system of mimnte chammels. In sections stained with hrenatoxylin the matrix of lyaline cartilage often acquires a faint bluish tinge, the eytoplasm of the cells a decper shade of the same color, and the nuclear chromatin a very dark blue.

Hyaline cartilage forms the costal cartilages, the throvid eartilage, the ensiform process of the stermmm, the cartilages of the trachea and bronehi, and the tenporary cartilages which are subsequently repliced by bone.

2. Fibro-cartilage (Fig. 52). -This variety of cartilage is fomm in only a few situations: in the interarticular cartilages of joints, in some of the syuchondroses, in one regrion in the heart, and in the intervertebral disks. In the latter situapossess branching processes, extending for 
some distance between the fibres of the intercellular substance, and giving the whole tissue a character closely resembling that of

Fif. 5:.

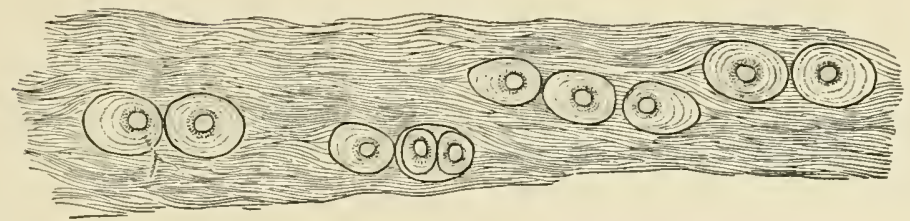

Fibro-cartilage. Section from human intervertebral disk. (Schäfer.) The cell to the left presents a branching process extending into the intercellular substance.

white fibrous tiswe. The cells are, however, more eytoplasmic than those of ordinary fibrous tissue.

3. Elastic Cartilage (Figs. 53 and 60).-This form of cartilage

Fig. 53.

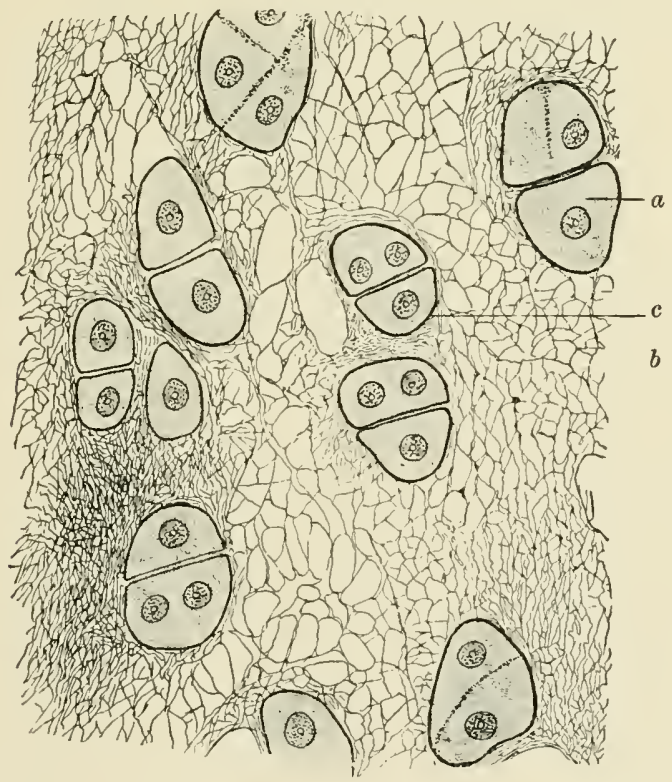

Elastic cartilage. Section from cartilage of human external ear. (Böhm and Davidoff.) $a$, cartilage-cell ; $b, c$, network of elastic fibres in the intercellular substance; $b$, with large meshes; $c$, fine-meshed. Opposite $a$ is a cell showing indications of a division of the cyptoplasm following division of the nueleus.

is found in the epiglottis, the cornicula of the larynx, the ear, and the Eustachian tube. The coarseness of the anastomosing fibrous network of the matrix varies in different situations and in different 
parts of the same piece of cartilage. The retieuhm is usually more open and composed of larger fibres toward the centre of the tissue than at the periphery, where it becomes more delicate and finally blends with the fibrous intercellular substance of the perichondrium.

It is evident, both from the structure of the eartilages and from the situations in which they are found, that they constitute elastic tissues suitable for diminishing the effects of mechanieal shock. This is obviously the ease in the joints, where both the hyaline and the fibrous varieties are found. Their elasticity and moderately firm consistency are also of obvious utility in the laryux and other air-passages and in the ear, nose, and synchondroses.

\section{BONE.}

General Characters.-(1) The cells of bone, called "bone-corpuscles," have an oval vesicular nuclens, surrounded by a moderate amount of ertoplasm, which is prolouged into delicate branching processes that join those of neighboring cells. (2) The intercellular substance is composed of an intimate association of an organic substance and salts of the earthy metals. (3) The arrangement of these constituents is as follows: the organic hasis of the intercellular substance is arranged in lamine, which are closely applied to each other except at certain points where there are cavities, called "lacunx," giving lodgement to the bone-corpuscles. Joining these lacme with each other are minute channels in the intercellular substances, "canalieuli," which are ocenpied by the fine processes of the corpuscles. In the compact portions of the long bones, and wherever the osscons tissue is abundant, the lamine are arranged concentrically around nutrient canals, the "Haversian canals," which traverse the bone, anastomosing with each other and containing the nutrient bloodvessels of the tissne. In eancellated bone these Haversian canals are absent, and the thin plates of bone are made up of parallel lamina of intereellular substance, between which are the lacune, connected with each other by canaliculi. The bone-corpuscles are nomrished from the fluids eirenlating in the marrow, which ocenpies the large spaces of this spongy variety of bone.

It is not possible in a single preparation to study even these gencral characters of bone. The earthy salts in the intercellular sub- 
stance prevent the preparation of sections by means of the knife, and, unless they be removed, specimens of bone must be made by grinding. This can best be accomplished after the bone has been dried. But drying the bone destroys the corpuseles, which appear as little desiccated masses, devoid of structurc, within the lacunæ. Ground sections of bone can, therefore, give only an ilea of the intereellular substance and the arrangement of the lacunæ, canaliculi, Haversian canals, etc. (Figs. 54 and 55). Sections may be cut if

FIG. 54.

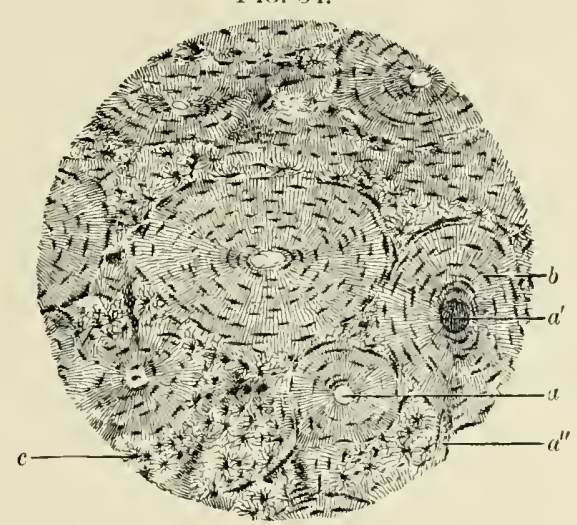

Ground section of dried bone. Iluman femur. $a$, Haversian canal in cross-section; $a^{\prime}$, Haversian canal occupied by débris; $a^{\prime \prime}$, anastomosing branch from $a^{\prime}$, in nearly longitudinal section; $b$, lacuna belonging to the Haversian system, of which $a^{\prime}$ occupies the centre; $c$, lacuna in excentric laminæ of bone between the Haversian systems. The delicate lines connecting the lacunæ are the canaliculi.

the bone be first decalcified-i.e., if the earthy salts be dissolved throngh the action of acids. This treatment not only removes the earthy constituents of the intercellular substance, rendering it soft and pliable, but causes the organic constituents to swell. The effect of this swelling upon the appearance of the bone is very marked. The fine canalienli are closed and the lacunæ diminished in size, so that the structure of the bone appears much simplified, being reduced to a nearly homogeneons mass of intercellular substance in which there are spaces arranged in definite order and enclosing the somewhat compressed bone-corpnseles. The delicate processes of the latter are not discernible within the canaliculi, but blend with the swollen intercellular substance forming the walls of those minute channels. It is important that the student should learn to recognize these mutilated preparations of bone, since it is 
in this form that the tisine will most frequently come under his olservation (Fig. 56).

Minute study of the structure of the intercellular substance of bone makes it appear that the organic basis is not homogeneous, but is composed of minute interlacing fibres, held together by

FI(i. 5).

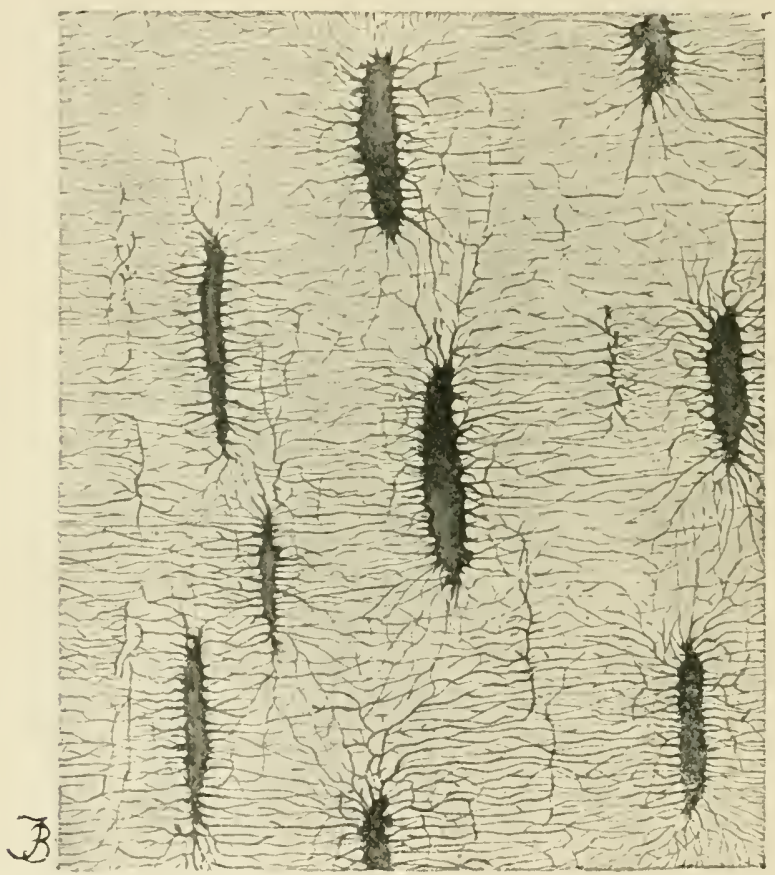

From a section through the bone of a roebuck. The bone cavities (lacunæ) are seen from the side. $\times 850$.

a cement or "ground" substance, eontaining the deposit of earthy salts. To these salts, which are chiefly phosphate and carbonate of ealcium, the bone owes its hardness, while the fibres contribute tonghnesin and elastieity to the tissue. The general arrangement of the fibres in the interecllular substance is in lamina, which have a general parallel lirection; but there are weeasional fibres of some size which pieree these lamine in a perpendicular direction and appear to biml them together, very much as a nail would hold a series of thin boarls in place, "Sharpey's fibres."

Bone occurs in two form:, the compact and the cancellated. These do not differ in the nature of the tissne itself, but merely 
in the arrangement of that tiscule with respect to its somrees of nourishment. Where the bone is massed in compact form, as in the shafts of the long bones, special means for supplying it with nomrishment is provided by a series of channels, the Haversian

FIG. 56.

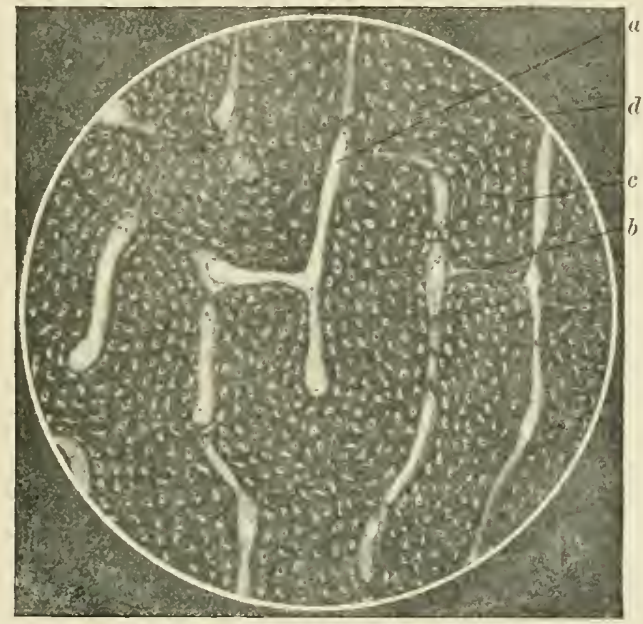

Section of decalcified bone, parallel to axis of human femur. a, longitudinal section of Haversian canal giving off transverse branch to the left; $b$, tangential section of a transverse branch ; $c$, lacuna occupied by bone-corpuscle; $d$, intercellular substance deprived of its earthy salts and so swollen that the canaliculi are olliterated.

canals, which contain the nutrient bloodvessels, and which anastonose with each other throughout the whole substance of the tissue. The nourishing lymph, derived from the blood, reaches the cells through the eanalienli and lacunx, whieh conneet with each other to form a network of minute channels and spaees pervading the bone, and not only opening into the Haversian eanals, but also upon the external and internal surfices of the tissue.

In the shafts of the long bones the Haversian canals lie for the most part parallel with the axis of the bone, with short transverse branches connecting then with each other. It is aromnd these longitudinal Haversian eanals that the laminse of bone are arranged in eoncentric tubular layers. Each Haversian canal, with the laminse surrounding it, is known as an Haversian system. Between these Haversian systems there are excentric lamina of bone, which do not eonform to the concentric arrangenent of the Haversian systems. 
In the spongy or eancellated rariety of bone the thin plates of that tissue derive their nourishment from the lymph of the contignous marrow filling the spaees between them, and there is no occasion for Haversian eanals. The concentric arrangement of the lamine is, therefore, absent.

Except where bounded by eartilage at the joints, the external surfaces of the bones are covered by a fibrous investment, the periosteum, in which the blondvessels supplying the bone ramify and subdivide before sending their small twigs into the Haver-ian canals of the compact bone. A few nerve-fibres also penetrate into the bone from the periosteum. The deep surface of the periosteum contains connective-tissue cells, "osteoblasts," eapable of assuming the functions of hone-corpuscles and producing bone. In places where the bone is developing, these osteoblasts are large and cytoplasmie, somewhat resembling the cells of cuboidal epithelium. These facts explain the importance of the periosteum for the nutrition and growth of bone. The tendons and ligaments attached to the bones merge with the periostenm, which has a similar fibrous structure and serves to connect them firmly with the surface of the bone.

The central cavities of the long bones and the spaces of eancellated bone are occupied by marrow, which may be of two kinds, the "red" or the "yellow." A description of the structure of marrow must be deferred until the other varieties of the eonneetive tissues have been considered.

In the embryo the parts which are destined to become bony first consist of some other variety of connective tissue, either cartilage or fibrous tisile. This subsequently "ossifies," during which process it is not really converted into bone, but is gradually ab-orbed as that tissue develops and replaces it.

Because of its hardness and enmpact structure it is, perhaps, a little difficult to realize the plistic character of bone, and to understand the growth and gradual changes that take place in a tissue that would seem to he so permanent. These changes are wrought by the absorption of hone already formed and the deposition of new bone. The long bones increase in length as long as the epiphyseal cartilage persists; this eartilage grows and is constantly being replaced by bone formed at its junction with the shaft. Bones increase in diameter by the deposition of fresh osseous tissue produced by the osteoblasts forming the deep layer of the periosteum. As the osteoblasts 
multiply some of them become bone-corpuscles and through their action new intercellular substances are produced. 'The marrow eavity also enlarges. This is brought about by large multinuclear cells, "osteoclasts," which canse the absorption of the intercellular substances of the bone with which they lie in contact, producing little excavations, the Howship's foveolæ or lacunæ (Fig. 57). 'Through

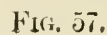
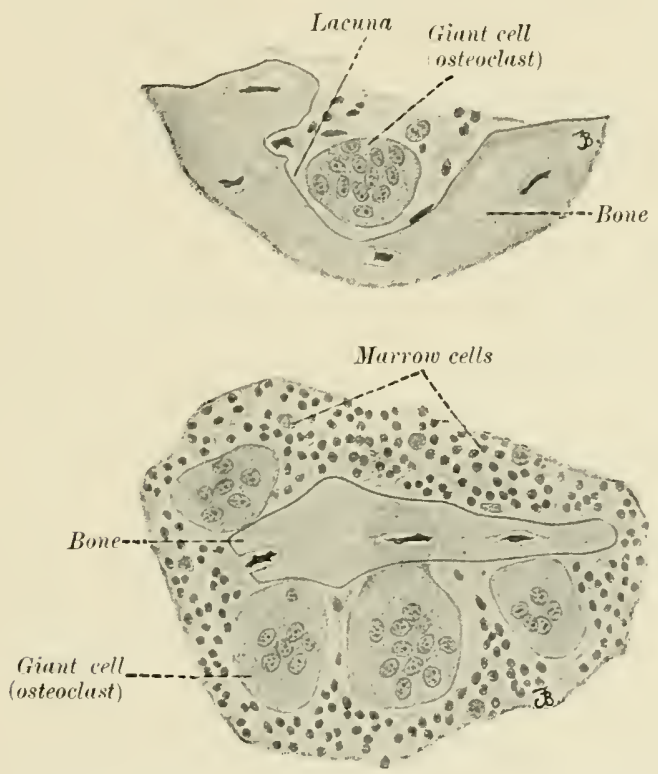

From a longitudinal section of the femur of a rabbit's embryo. $\times 335$.

the agency of the osteoblasts and osteoclasts the bone is gradually moulded to meet the demands upon it. In muscular individuals the ridges and spines to which the tendons or muscles are attached become larger and more prominent and the arrangements of the bony plates in cancellous tissue are adapted to withstand the strains resulting fiom pressure bearing on the surfaces of the bones. The eccentric lamina of bone already mentioned as existing between the Haversian systems of compact bone are probably remains of former complete systems which have heen partially absorbed and replaced by the existing systems of more recent production. 


\section{THE FIBROUS TISSUES.}

General Characters.-This group of elementary tissues, which may be said to constitnte the connective tisues par excellence, inchules a number of varieties which are not very sharply defined, becanse of transitional morlifications which bridge over the differences between the more distinet types. It will, therefore, be best to describe these well-marked trpes of structure, and then to indieate the direction in which they are morlified in particular cases so as to simulate in greater or less degree other typical varieties of the same group.

(1) The cells of the fibrons tissues vary considerably in chancter, three more or less distinct forms being distinguishable. First, flattened, almost membranous cells with oval nuclei and nearly clear and homogeneons bodies, possibly identical with the cells that form endothelium; second, granular cells, rich in cytoplasm and usually ovoid or cubical in shape, though sometimes elongated ; third, elongated or fusiform cells, with oval nuclei surromeled by a moderate amount of cytopla-m which is frequently prolonged into processes of greater or less length and delieacy, and sometimes dividing into branches. These three sorts of cell are present in varying relative proportions in the different tissnes belonging to this group. The intercellular substance is composed of distinct fibres, associated with a homogeneous cement- or "groumd-substance," ]ying between the fibres. The fibres are of two kinds: the "white," non-elastic, and the elastic or "vellow." The relative abundance of these and of the ground-substance associated with them, and also their arrangement, vary greatly in the different members of the group. (3) The alrungement of the constituents of the fibrous tissues in the different varieties is so diverse that a statement of the variations wouk amount to a description of the tissues themselves. The general characters already enmerated will serve to distinguish the whole group from all the other elementary tissues, and enable the student to recognize the fact that a given form of the tissue which he may have under observation belongs to this group.

Before entering upon a description of the rarieties of fibrous tissue, it will be of advantage to note the peculiarities of the two linds of fibres that are found among their interechlular substance.

The white, non-elastic fibres (Fig. 58) are exceedingly delicate, 
and appear, even under high powers of the microscope, ats fine, transparent, homogeneous lines. They are usually aggregated into bundles of greater or less thickness, being held together by a small amount of the eement-substance alrearly referred to. In these bundles the fibres rma a somewhat wary course from one end of the bumdle to the other, but lie parallel to each other and never branch. When treated with dilute acetic acid, withont previous hardening, they swell and become almost invisible. They are converted into gelatin when boiled in water.

The yellow, or elastic, fibres (Figs. 59-61) are coarser than the white and more highly refracting, appearing more conspicuons when viewed under the mieroseope. They may be nearly straight, but

Fic. 58 .

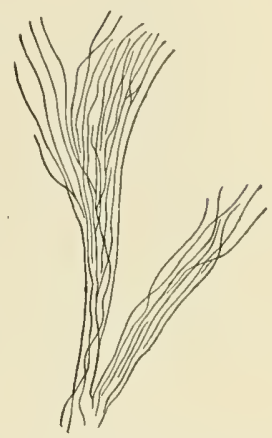

Fibres of white fibrous tissue teased apart to show the individual fibrils.

more usually run a simnous eourse. At intervals they divide, and the branches anastomose with each other to form a fibrous network, the
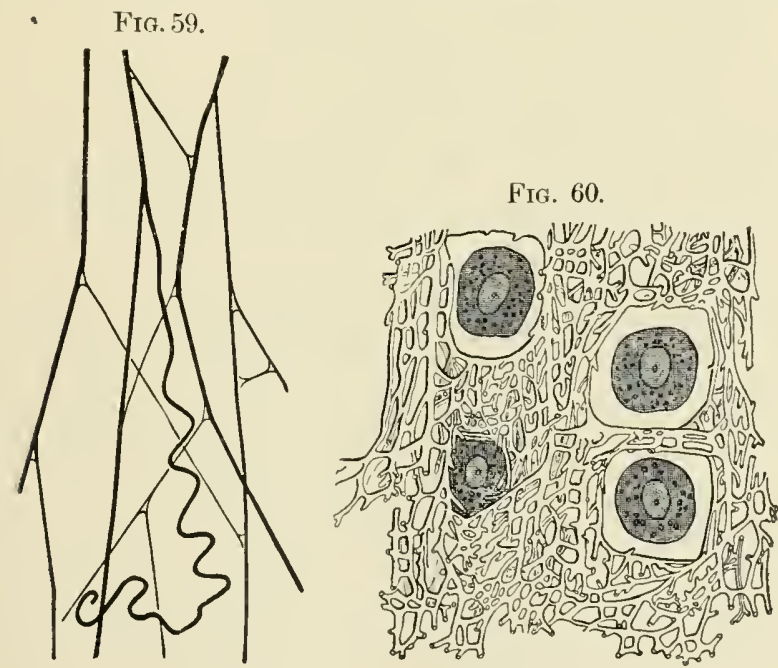

Fig. 61.

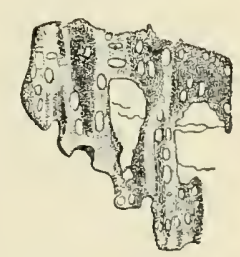

Elastic fibres.

Fig, 59.-From the subcutaneous areolar tissue of the rabbit. (Fchäfer.)

FIG. 60.-Section of ear. (Hertwig.) The intercellular substance contains a reticulum of coarse anastomosing elastic fibres. (See Fig. 53.)

Fig. 61.-Fenestrated membrane from a branch of human carotid arters. (Triepel.)

meshes of which may be large, as is the case in areolar tissue, or so small and bounded by such broad fibres that the network resembles 
a membrane pierced by somewhat elongated apertures, as is exemplified in the fenestrated membranes of the arteries. The formation of such a network is, however, not an essential characteristic of these fibres, for they appear as isolated wavy fibres in some of the fibrons ti-smes of open and loose structures. Elastic fibres are not affected by acetic acid, nor do they yield gelatin on boiling in water. According to Schwalbe, they have a tubular strueture, consisting of a membrane enclosing a substance called "elastin."

We may now turn our attention to the different varieties of the fibrous tissues.

\section{Fici. 62.}

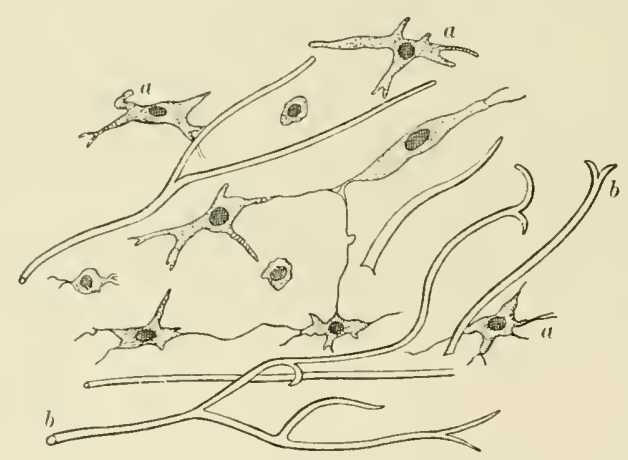

Iucous tissue. (Ranvier.) $a$, stellate cells with long and branching processes; $b$, elastic fibres in the homogeneous, mucoid, intercellular sulstance, which is not visible under the microscope unless artificially colored. Three of the cells are represented in cross-section.

1. Mucous Tissue (Fig. 62).--The eells of this elementary tissue are chiefly of the third varicty mentioned above. They are spindleshiped or stellate in form, and many of them possess processes that extend far into the intercelhular substance, where they may branch and mite with the processes of neighboring eells. The predominant constituent of the intereellular substance is a gelatinous gromol-substance, which contains a variable amount of muein and appear's nearly, if not quite, homogeneous under the microscope. It is this which gives the whole tissue its soft and gelatinous consistency. A variable number of fibres of both the kinds already deseribed rmu through this ground-substance. The white fibres are arranged in fine loundles, lut the elastic fibres appear to be isolated ancl, though they may branch, do not appear to form a network. The mamner in which the fibres in the interecllular substances of this and other forms of connective tissue are formed is not understood. 
According to one view, they are produced from and by the eytoplasm of eonnective-tissue cells, which, in consequence are often called fibroblasts (Fig. 65). It is diffieult to understand how this ean be true in all eases, and mueous tissue offers an example of one of these. Another view is that the fibres are formel within the intercellular "ground substance" $-i$. $e$., the apparently homogeneous material lying between the cells and fibres-as a sort of coagulum or segregation of the substances constituting the fibres.

Nucous tissue of a rather highly cellular eharaeter is abundant in the embryo, where it constitutes an early stage in the development of the fibrous tissues (Fig. 63). A variety less rich in cells forms

FIG. 63.

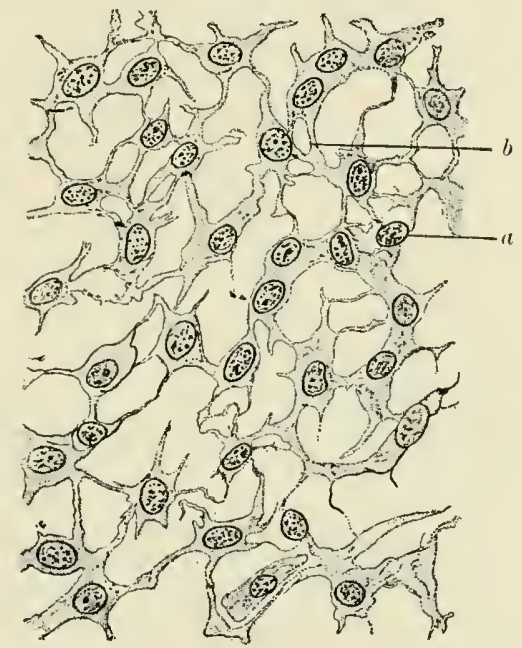

Embryouic connective tissue (mesenchymatous tissue). (Böhm and Davidoff.) a, nucleus of stellate cell; $b$, eytoplasmic process. The intercellular substance is of gelatinous consisteney and optieally bomogeneous.

the Whartonian jelly of the umbilical cord. It does not occur in the adult under normal conditions, except, perhaps, in the vitreous humor of the eye.

2. Reticular Tissue (Fig. 64).--The fibres of this variety of elementary tissue are disposed in extremely delicate bundles, which anastomose with each other to form a fine meshwork. The spaces between the fibrous bundles are filled with lymph, which is usmally so crowded with cells similar to the white blood-corpuseles that the structure of the tissue is masked by their presence. The eells of 
this tissue are flattened and closely applied to the surfaces of the bundles of fibres, which are so fine that they simulate delieate branching processes emanting from the cells. The cement- or ground-substance is reduced to a minimum, only a small amount lying between the fibres and the cells of the reticulum. The tissue is bounded by denser forms of fibrons tissue, with the fibrous bundles of which the reticulum is continuous. It is possible that reticular tissue contains stellate cells of the third variety mentioned as occur-

FI(*. 64.

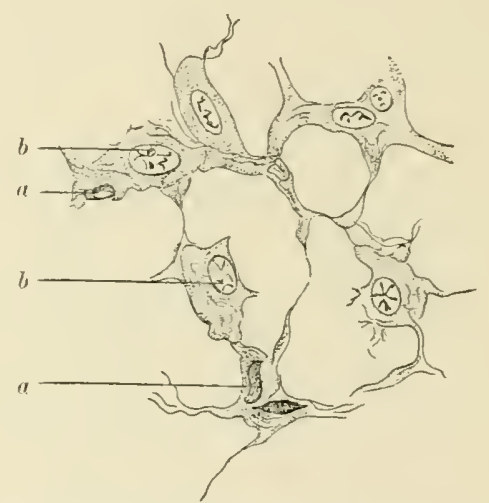

Retieular tissue. Section through a lymph-sinus in a lymph-node of the rabbit. (Riblert.) $a$, nuclei of stellate cells of the reticulum; $b$, endothelial cells which are closely applied to the reticulum. The lymplioid cells, or lencocytes, have been removed from the meshes of the reticulum.

ring in fibrons tissues, as well as the thin cells already described, which belong to the first variety. Where this is the ease it is probable that the branching processes of those cells take part in the formation of the reticulum.

Where the meshes of the reticulum are erowded with lymphoid cells-i.e., cells identical with some of the white corpuseles of the blood-the tissue has received the name "Iymphadenoid tissue." This tis-ue is the chief constituent of lymph-glands and follicles, and is also foumd in a more diffuse arrangenent in many of the mueous membranes (Fig. 11t, L).

3. Areolar Tissue.-This is the most widely distributed variety of fibrous tistue. It contalins all three kinds of eells mentioned at the heginning of this section, thongh not always in the same relative abundance. The intercellular substance consists chiefly of bundles and lannine of fibres, which interlace in all directions. The white fibres prectominate wer the alastic, but there are always some of the 
latter which either form a wille-meshed reticulum, interlacing with the bundles of white fibres, or are applied to the latter in a sort of open spiral, binding them together. In the developing tissue the cement-or ground-substance at first fills all the interspaces between the cells and the fibres; but as development proceeds spaces appear in the tissne, which are ocupied by lymph and intereommunicate throughout the tissue. The ground-substance is then restrieted to a mere eement uniting the fibres within the bundles and laminx. The flat or endothelial cells of the tissue lie within these bundles or are applied to their surfaces, forming a more or less perfect lining to the lymph-spaces within the tissue and hecoming eontinuous with the endothelial walls of the lymphatic ressels. It is within these spaces that the lymph aceumulates after its passage through the walls of the smaller bloodvessels, to find its way into the lymphatic circulation. The spindle-shaped aud cuboidal cells of the tissue lie between or within the bundles of fibres embedded in the cementsubstance (Figs. 65 and 66).

FIG, 65 .

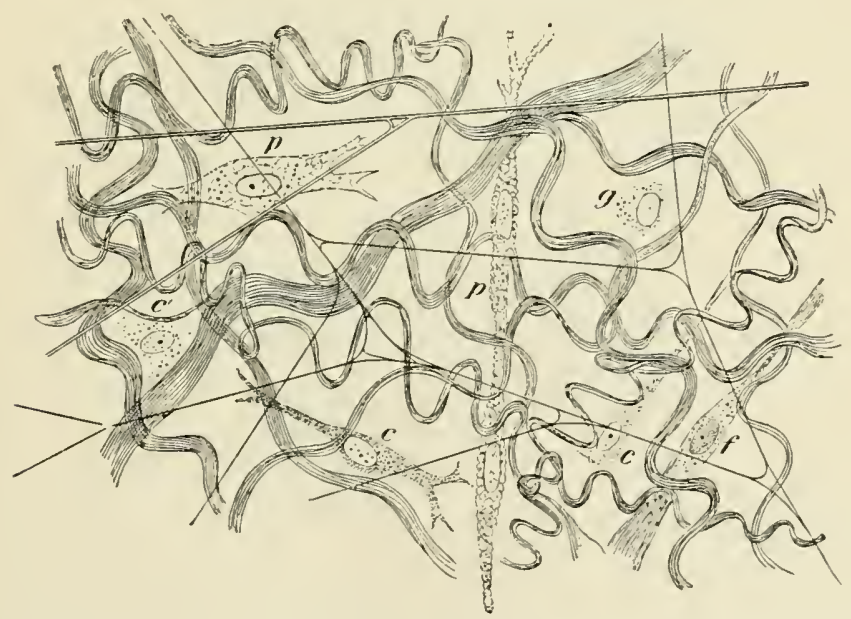

Arenlar tissue. Preparation from the subcutancous tissue of a young rabbit. (Fchifer.) $c^{\prime}$, endothelioid cell; $p, p$, cells with granular cytoplasm; $c, c, f$, cells of the fusiform or stellate variety not yet fully developed. The white fibres are in bundles pursuing a way course; the elastic fibres are delicate and form a very open network; $g$, leucoeyte of a coarsely granular variety.

A reolar tissue varies greatly in different situations in the density of its structure-i.e., in the size of the fibrous bundles and their relative abundance, as compared with the number and size of the 
spaces separating them. The name is derived from that form in which the strueture is open and the comrses of the filowe bundles very liverse, so that they interlace, leaving relatively lare spaces between them. In this form it oeenrs in the subentaneous tissues, between the muscles, forming the loose fascire in that situation, and in many other parts of the hody where adjacent structures are loosely connected with each other. The sinnous course of the interwoven fibrons bundles renders the tis-ue easily distensible in all directions and permits considerable freelom of motion between the parts which it unites.

In other situations the spaces in the tissue are smaller and the

FIG. 66.

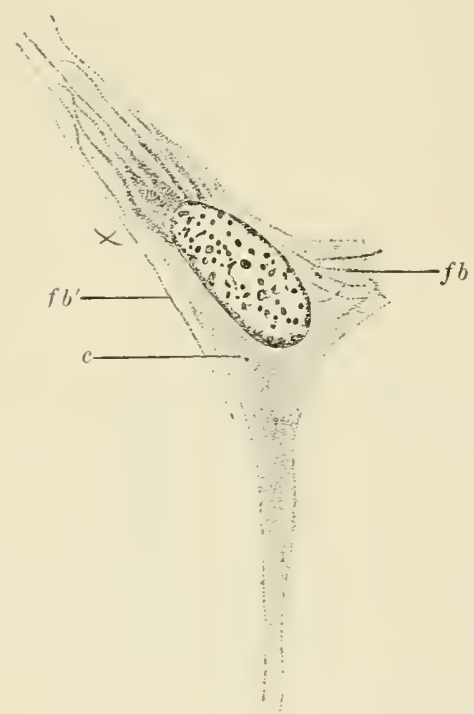

Cell from subcutancous tissue of human embryo. (spuler.) $c$, centrosome; $f h$, fibrille in the cytoplasm of the cell; $f b$, fituril detached from the cell, but evidently derived from it. This cell corresponds to $c, c$, aml $f$, in Fig. fi3. They are sometimes called tibroblusts beanse of their activity in the formation of fibres. fibrous bundles closer together and less tortuous in their arrangement, so that the parts connected with each other are more fimly held in place. This form of the tissne oeenrs in all the glandular organs of the body, supporting and holding in place the functionally active tissues of the organs and constituting the chief constituents of their interstitia (sec Chapter VII.). To distinguish this form of fibrous tissue from the areolar or more open form it may be designated as conneetive tissue in a more restricted use of that term than has hitherto been employed or ats interstitial connective tissue ( $\mathrm{Fig} .67, b, b^{\prime}$ ).

A still denser form of the tissle oceurs in the fiscice and aponenroses, in which the fibres are aggregated in thiek bundles and layers that run a eomparatively straight course and are firmly held

togrether. Ligaments and tendons differ from these only in the greater density of the fibrous bundles and in their parallel arrangement. These denser varieties of the tis-ues may be designated by a restricted wse of the term, fibrous tissur. 
4. Adipose Tissue (Fig. (77). - Fat or adipose tissue is a modification of the more open or lonsely-textured areolar tissue, canced by the accumbation within the eytoplasm of the enboidal cells of drops of oil or fat. 'The cells which have become the seat of this fatty infiltration are enlarged, and their cytoplasm, with the enclosed muclens, is pressed to one side, the sreat bulk of the cell being ocenpied by a single large globule of fat. This globnle, together with the cytoplasm, is enclosed in a delicate cell-membrane. The fatty cells may occur singly in the midst of an apparently normal areolar tissue of the usual type, but they are more frequently grouped to form "lobules," held in position within the tissue by bands and lavers of unaltered arcolar tissue.

In sections of adipose tissue prepared after hardening the tissue in alcohol the fitty globules can no longer be seen, since the alcohol dissolves the fiat from the tissues. The partially collapsed

FIG. 67 .

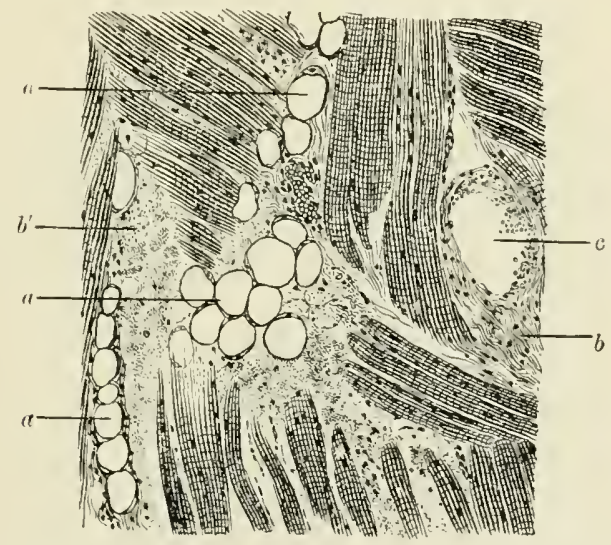

Section from the tongue of a rabl,it : $a, a, a$, grouls of fat-cells forming small masses of adipose tissue in the connective tissue; $b, b^{\prime}$, fibrous tissue, $b$ in longitudinal, and $b^{\prime}$ in cross-section; $c$, small vein containing a few red blood-corpuseles. Near the eentre of the figure is another bloodvessel filled with corpuseles. The remainder of the figure represents striated musele-fibres in nearly longitudinal section. In the npper left hand corner these show a tendeney to split into longitudinal fibres (sareostyles).

membranes of the cells, with the eytoplasm and contained nueleus forming an apparent thickening at one side, are all that remain to distinguish the tissue (Figs. 67, a, and 68).

Adipose tissue is widlely distributed in the borly. It serves as a store of fatty materials which ean be drawn "1pon as a reserve 
stock of food when the nutrient supply of the body falls below its needs.

The usefulness of the fibrous tissnes ean be realily inferred from their structure. The more open varieties of areular tissue serve to give support to the struetmes they mite and to the bloodvessels, lymphaties, and nerves supplied to them. They also atford spaces and channels for the return of the lymph, which transudes throngh the walls of the eapillary bloodvessels, carries nourishment to the tissne-clements it bathes, and then returns to the hlood in the reins through the interstices and lymphatic ressels contained in the areolar tissue. In pursuanee of these functions, areolar tissue pervades nearly all parts of the body. Wherever bloodvessels are found, there more or less areolar tissue is present, surromeling them, giving them support, and furnishing channels for the lymphatic circulation. As has alreacly been stated, this areolar tissne varies in the eloseness of its texture in different parts of the body. The fibrons tissues of tendons and ligaments form inextensible

FIG. 68.

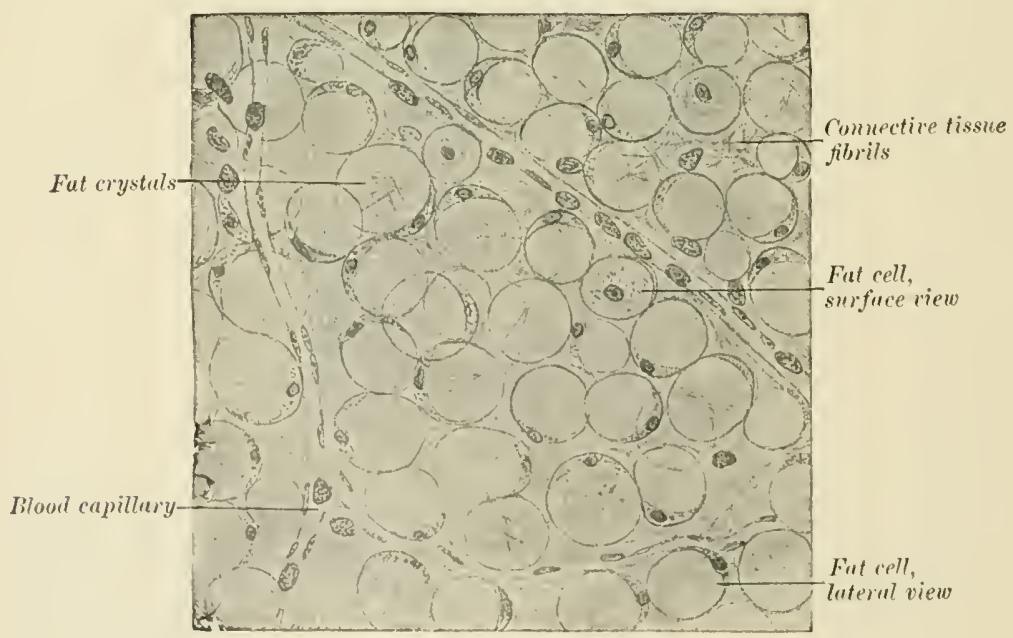

Fat from the subeutanenus layer of the skin of a white mouse $\times 200$.

bands or eorels highly lesistant to tensile stress, but very pliable. They (onsist of bumlles of filnes lying parallel to each other and to the direction in which they are to resist pulling forces. Layers of loose areolar tissue penetrate the ligaments and tendons, dividing them into fisciculi, which in turn are united into larger hundles by 
thick layers of areolar tissue (Fig. 69). 'These sheaths of areolar tissue support the vessels and nerves supplied to the denser forms of the fibrous tissue making "p the ligaments or tendons. 'The thicker aponeuroses of the body maly be regarded as broad and flat

Fig. 69.

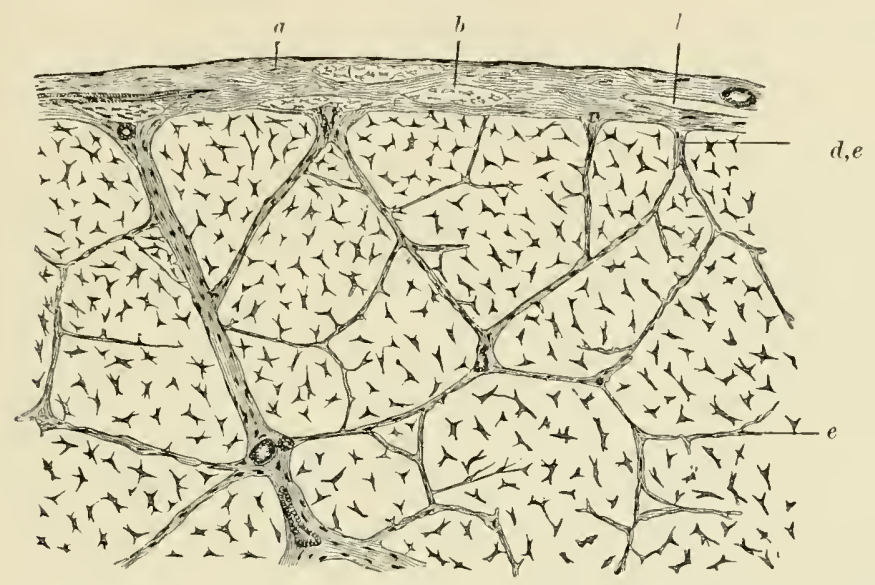

$c$

Portion of a large tendon in transverse section. (Schäfer.) $a$, sheath of areolar tissue surrounding the tendon; $b$, longitudinal fascirulus of fibres within that sheath; $l$, lymphatic space; $c$, section of a broad extension of the ensheathing areolar tissue, dividing the tendon into larger bundles; $d, e$, more delicate layers of areolar tissue subdividing the larger bundles of fibres. Between these areolar sejta are the bundles of fibres constituting the tendon. The cells which lie between the smallest faseieuli of fibres appear in stellate form; the eross-sections of the individual fibres, among which these cells lie, are not represented. They would appear as minute dots.

ligaments, in which the bundles of fibres run in various directions. They present a structural transition between the fibrous arrangement in ligaments and tendons and that in the more open varieties of areolar tissue. The fibres of these tissues are mostly of the white variety, but in some situations, notably in the ligamentum nuche, they are chiefly of the elastic variety.

Reticular tissue may be regarded as a special modifieation of arenlar tissue, in which the main bulk of the tissue consists of a series of freely intereommmicating lymph-spaces. These are often densely crowded with lymphoid cells, among which the lymph slowly eirculates, thereby being subjected to the modifying influences of their aetivities. 


\section{CHAPTER V.}

\section{TISSUES OF SPECIAL FUNCTION.}

The elementary tissnes ineluded in this gromp are highly differentiated in structure so as to adapt them for the performance of some special function of a high order. The constituent of the tissues which appears most highly specialized is the eell, which is often so greatly modified in strueture as to have lost many of the general characters of the cells hitherto studied. Thus, for example, the cells of striated muscle are multinueleated, and the eytoplasm has become transformed into a substance known as contractile substance, which occupies nearly the whole bulk of the cell, leaving only a small amount of relatively undifferentiated eytoplasm immediately surrounding the muelei.

In like manner the intercellular substances of some of these tissues show a complexity of strueture in great contrast to those with which we have become familiar in the preceling tissues. In fict, it is stretching a point to regard the tissues lying between the cells of striated muscle as forming an intereellular substance belonging to that tissue. In this case those tissues are identical in structure with the loose areolar tissne that was described in the preceding chapter. We may, therefore, with propriety, regard the striated muscles as orguns in which the muscle-cells constitute the parenchyma and this areolar tissne the interstitium (see Chapter VII.). But in other tissues of the group there is either an intercellular substance resembling these of the preceding tissues, or some special form of sustentucular tissue-. g., the nemroglia of the central nervous system.

The tissues of special function are arranged in two groups: the muscular tissues and the nerrous tissues. As is implied in the title, these tissues are grouped together because of their functional powers, and not with regurd to peenliarities of strueture, so that it is imposible to give concise statements of any common general structural charater possesed by all the members of each of these 
two groups. Thus, the individual muscular tissues differ considerably from each other in structure, but are closely related in function, each variety being specialized so as to exeente a particular kind of contraction when functionally active. We must also assume that the variations in structure met with in the nervous system have reference to the translation of varions impressions into nervous impulses, or the liberation of such impulses under different conditions, as well as to their tranmission and application to the functional ativities of other tissues.

The complex functions exereised by the nerrous system appear to necesitate a great variety of nervous structures, and it would be a matter for surprise to find the visible strneture of the nervous system as simple as it is, were it not for the fact, already learned, that eells apparently similar in structure may have widely different, though related, functional powers.

\section{THE MUSCULAR TISSUES.}

There are three varictics of muscular tissue, which differ from each other both in structure and in the character of their functional activities. One variety is that found in the walls of the hollow viscera and larger bloodvessels. Its activities are not under the control of the will, and the cells are devoid of marked cross-striation of the contractile substance. It has, therefore, received the names, "involuntary" or "smooth" muscular tissuc. The other two varieties present distinct and rather coarse cross-striation of the contractile substance, but differ in other structural details. One of these is called "voluntary" or "striated" muscle; the other is found only in the heart, is not under the control of the will except in rare instances, and is known as "cardiac" muscular tissne.

1. Smooth Muscular Tissue.-This elementary tissne is composed of elongated or fusiform cells, which gradually taper to a sharp point. The body of the coll, except close to the ends of the nuclens, consists of a modified cytoplasm, called "contractile substance," which stains a coppery red with eosin, and presents fine, indistinct, longitudinal and transverse markings, possibly the optical expression of certain ridges that are in contact with similar ridges on neighboring cells. Each cell has a single, greatly elongaterl, rod-shaped nueleus situated in its centre, with the long axis coincident with that of the cell (Fig. 70). The nuclei are vesienlar and possess 
a distinct intranuclear reticulim of chromatin. The intercellular substance is a mere cement of homogeneons character.

Fro. 70. The cells are arranged with their long axes parallel to each other and with the tops of their mintute rilges in contact, so that fine chamnels exist between the contiguons cells. This is apparently a provision for the circulation of nutrient fluids between the cells (Fig. 71).

Recent studies of the intercellular regions of smooth muscular tis-ne cast some doubt npon the existence of the minute ridges described above. The appearances taken for such ridges may, in reality, be produced by a fine meshwork of delicate fibrils which eneircle the musclecells and bind them together. In the spaces betwoen these fibrils there is opportmity for eirenlation of the tiscuefluids. This view also does away with the idea of a cementsubstance holding the cells tugether. The reactions which led to the belief in a cement may be due to proteids in the tissue-fluids present in this situation. This conception would malie the structure of smooth muscular tissue, as far

F1木. 71 .

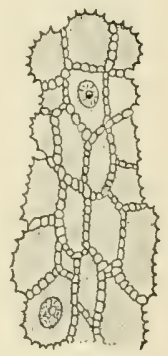

Smouth muscular tissue.

FIf. 70, $-\mathrm{An}$ isolated fibre from the museular cnat of the small intestine. (Schäfer.) The nucleus is somewhat contracted, so as to appear broader and shorter than when in the extended state.

Fig. 71. - ('ross-section of sinooth muscular tissue: human sigmoid flexure. (Barfurth.) Two of the muscle-cells have been cut in the region occupicd by the nucleus, which appears in round cross-section. The other cells have been cut between the site of the nucleus and the end of the cell. The structural details of the eytoplasm or contractile substance are not represented, hut the connecting ridges of the cells, with the channels between them, are shown. These minute rillges can, however, only be seen when the tissue bas been exceptionally well prescrved and is studied under a high power of the microscope.

as the interellular -nbstances or structures are coneerned, analogous to those of striated and eardiac museles. 
Smooth muscular tissue occurs in the form of bundles or layers, in each of which the colls or fibres run in the same direction. The tapering ends of the individual cells interdigitate with each other, masking the intercellular substance, so that the tissne appears as though wholly composed of cells. Surrounding the musenlar bundles or between the layers of that tissue is vascularized areolar tissue, griving it support and containing its nelve-supply.

The microseopical appearances of sections of smosth muscular tissne depend upon the dircction in which the individual cells have been cut. A brief analysis of the different appearanees that may result will be useful as an illustration of the way in which microscopical appearances must be interpreted in order to gain a correct conception of the structure of an object under observation. It is rarely that sections happen to be made in such a direction that they reveal the complete structure of an object. It is nearly always necessary to study the appearances presented hy the section, and to infer what the structure of the object must be in order to yield the appearances seen. This is sometimes a matter of considerable difficulty.

If the plane of the section lie parallel with the long axes of the cells, the nuclei of the latter will appear as rod-like or long, oval bodies lying parallel to cach otlıer and distributed at regular intervals throughout the tissue. The outlines of the cells will be distinetly visible in some places, but in most of the section the boundaries of the deeper cells will be obsenred by the bodies of the eells at the surface of the section, and the borders of the latter will be difficult of detection, because in many places the knife has left only a portion of the cell with a very thin and transparent edge (Figs. 72 and 73). For the practical recognition of the tissue, when eut in this direction, we must, therefore, in many eases, depend solely upon the shape and distribution of the nuclei and the color of the material between them after the section has been treated with certain stains (e. $/$, eosin).

If the cells of the tissue have been ent perpendieular to their long axes, the section will contain true cross-sections of the individual fibres. These appear as round, oval, or, more usmally, polygonal areas of various size, according to the part of the cell included in the section. If the cell has been ent near one of its ends, the eross-section will be small ; if near the middle, it will be large, and will contain a cross-section of the nucleus, situated ncar 
FIG. 7:2.

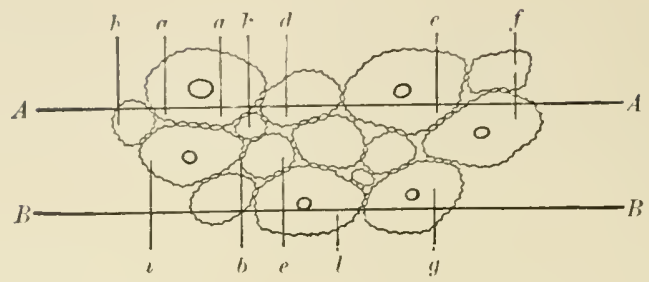

FIg. 73.

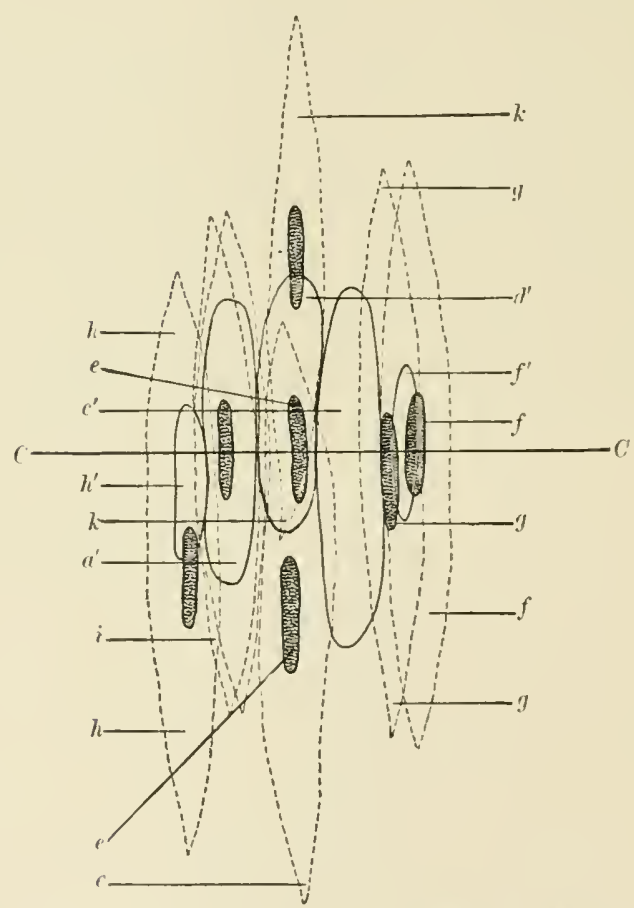

Diagrams illustrating the appearance of a longitudinal section of smooth muscular tissue.

The aistance between the lines $A A$ and $B B$ in the upper figure represents the thickness of the section, the line $A$.I being in the plane of itsuper surface. The line $C$ C in the luwer figure is in the plane of the transverse section represented in the upper figure.

It will be noticed that only portions of the eclls, $h a, d$ and $f$, will be contained in the longitudinal section (luwer firure). The upper cut surfaces of those cells will appear as oval areas when seen from abore, $h^{\prime}, a^{\prime}, d^{\prime}, c^{\prime}, l^{\prime}$. Where the edges of those sections are thin-c. $g, n-$ the ontlines of the corresponding oval $\left(a^{\prime}\right)$ will be difficult of detection At the same time those yortions of cells which lie at the top of the section will obsenre the ontlines of the cells beneath. Thus, at the point $b$ the outlines of the cells $i$ and $e$ will he ditlicult of deteetion beeanse rovered by the cells $k$ and $r$. and also beeause the eell $i$ overlaps the cell $e$. If the plane of junetion were perpendieular to the surface of the sertion, the ontlines of $i$ and $p$ wonld be much more clearly defined.

This brief ansl wis will surve tu show that the outlines of the cells will rarely be seen with distiurctness in longitudinal sections of smonth muscular tissue. On the other hand, the utule of the cells will he prominently visible in stained seetions because of the color they have rereived. For the recognition of this tissue, when so cut, we must, therefore, depent chietly upon the eharacter and distribution of the nuelei.

In orter to avwid an mnecessarily comblicated diagram, many of the cells represented in the upper cut have been omitted from the lower tigure. 
its centre and appearing as a round dot (Fig. 74 ). It is in such sections that one may sometimes see the minute prickles or ridges, already referred to, projecting from the cell-lodies and joining with those of the contiguous cells to form delicate

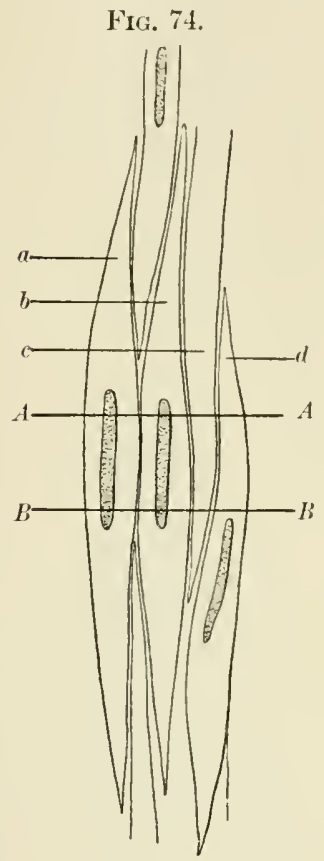

Fig. is.

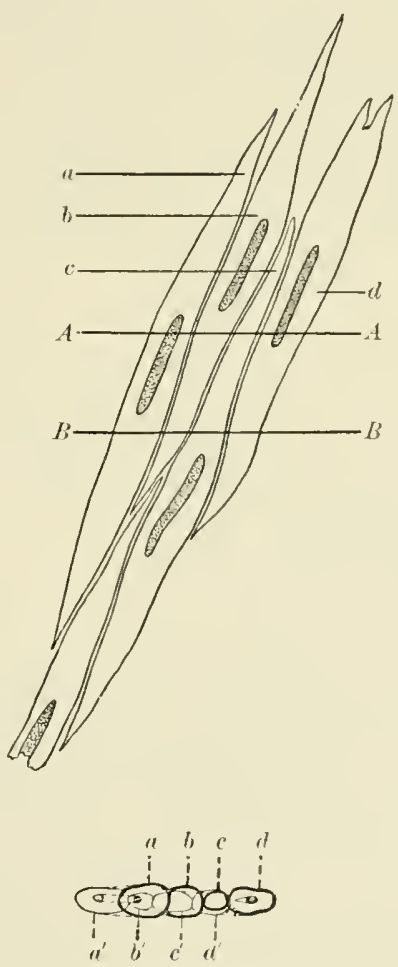

Diagrams of smooth muscular fibres eut in various directions.

FIG. 74. - Fibres cut exaetly perpendieular to their long axes. The lines $A A$ and $B B$ in the upper figure indicate the portions of the fibres included in the section, whieh is viewed from above in the lower figure. The cross-sections of the fibres $a$ and $b$ contain crosssections of the nuclei; those of $c$ and $d$ are smaller and devoid of unelei.

FIG. 75.-Fibres cut obliquely to their long axes. When the upper surface of the section, marked by the line $A A$ in the upper figure, is in sharp foets, the sections of fibres appear as in $a, b, c$, and $d$ of the lower figure. When the bottom of the section, indicated by the line $B B$ in the upper diagram, is in clear view, the sections of the fibres appear as shown at $a^{\prime}, b^{\prime}, c^{\prime}$, and $d^{\prime}$. It will be noticed that the optical section of fibre $a$ in the upper diagram has moved from $a$ to $\alpha^{\prime}$ in the lower diagram. As the focus was changed, the nucleus in fibre $a$ was constantly present and its optical section appeared of uniform size. This could only be the case when the nucleus was rod-shaped and of the same diameter throughout that portion continined in the section. In the fibre $d$ the nueleus was visible when the upper surface of the section was in focus, but disappeared when the focal plane was depressed. 
bridges across the narrow intercellular spaces. The only tisue with which this aspect of smooth muscular tissue is liable to be confounded is dense fibrous tissue, as seen in the cross-sections of tendons or ligament- (Fig. 69). There we also see polygonal areas of various sizes, separated for the most part by only a thin layer of cement. But these areas never contain nuclei, becanse they are compored, not of cell-bodies, but of intercellular substance. The unclei of the flattened connective-tissue cells may be seen here and there apparently lying within the cement, the body of the cell being so thin as often to escape observation. These differences render it easy to distiugnish the two kinds of tissue in spite of their general similarity when seen in eross-section.

It is, of course, rarely that sections contain smooth muscular

Fig. 76 .
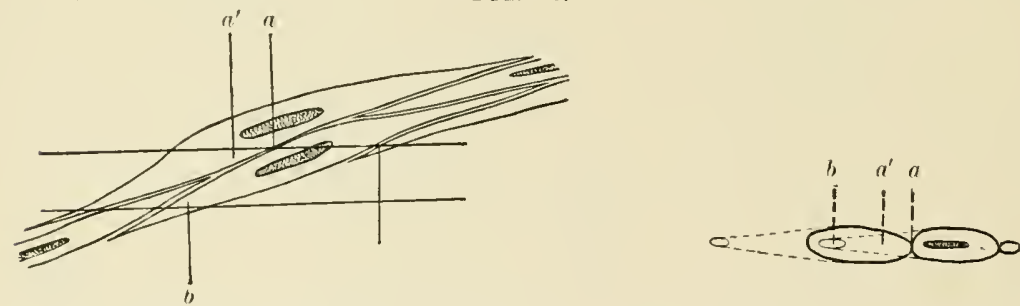

liagrams of smooth muscular fibres cut very obliquely. The explanation of Fig. 72 , already given, will make this one clear. In this case tle outlines of the fibres in section will be less sharply defined than in the preceding case, beeause, for instance, at the point $a$ the fibre $a^{\prime}$ is eut so as to leave only a thin edge, difficult of detection, and the fibre $b$ has had sueh a thin sliee remover from it that the loss would be hardly perceptible. The appearance of the section would, therefore, be much less casy of interpretation than is represented in the lower figure, where the outlines of the sections are equally distinct throughout.

tissne cut exactly in either of the directions just considered. In the majority of sections that come under observation the muscle-fibres are cut obliquely, and the oval or polygonal areas which result are, therefore, clongated. The nuclei of the cells lie at an angle with the line of vision, and, in consequence, appear foreshortened. If now we foems the instrument so as to get a sharp image of the upper surface of the section, and then rapidly turn the fine adjustment so as to bring the lower surfice into foenc, we shall notice an apparent lateral motion of the nuclei and cell-cetions. This apparent lateral movement, due to change of focus, is an evidence of the elongated shape and oblique position of the objects exhibiting it; and a little reflection will convince the student that such oblique sections, when 
carefully stuclied, are better calculated to reveal the shapes and relative positions of the tissue-chements than either perfect longitudinal or cross-sections. He should seek to train his powers of observation so that he may readily interpret the instructive, though at first confusing, inages presented by such sections (Figs. 75 and 76 ).

Smooth muscular tissue is not moler the direct control of the will. For this reason it is frequently ealled "involuntary muscle." It is also sometimes designated as non-striated or mstriped muscle, in contradistinction to the other two varieties of muscular tissue, the fibres of which present listinet eross-striations.

The functional contractions of smooth muscular fibres are sluggish. The fibres are slow in responding to stimulation, contract

Fig. 77 .
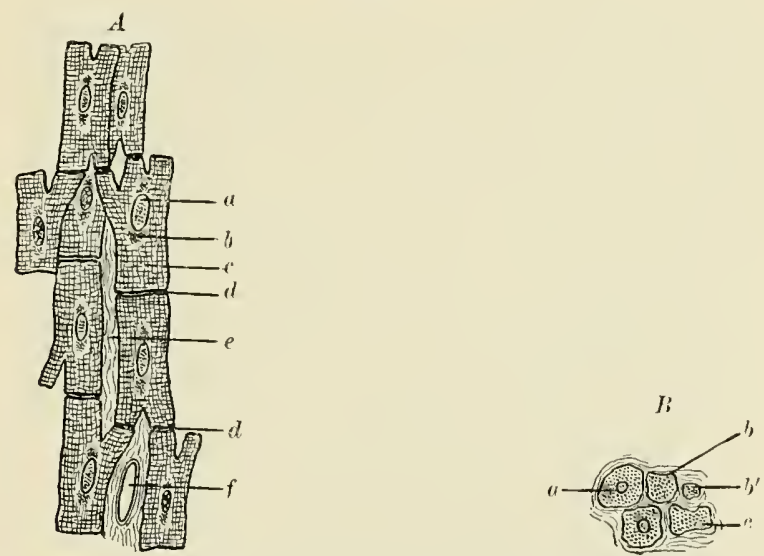

Diagrams of cardiac muscular tissue.

$A$, longitudinal section : $a$, nueleus of musele-cell; $b$, unmodified cytoplosm; $c$, eontractile substance with longitudinal and transverse striations; $d$, eement-substance uniting contiguous cells ; $\epsilon$, areolar tissue (vessels omitted) between the muscle-fibres formed by the union of the individual cells; $f$, small bloodvessel within the areolar tissue. If the lines of junction between the cells were not visible, the tissue would appear as though composed of interlaeing and anastomosing fibres, none of which could be traced for any eonsiderable distanee. Sueh is the usual appearance of longitudiual seetious of eardiac muscle.

$B$, transverse seetion: $\alpha$, section of a cell, including the nucleus; $c$, section above the nueleus and just below a erotch formed by the divergenee of a branch; $b$, section above the nueleus and the point where the branch $b^{\prime}$ is given off.

leisurely, maintain the contracted condition for a relatively long time, and then gradually relax. These propertics render the tissue of value in conferring "tone" to certain structures in which it is found, notably the walls of the arteries and veins. They also render it of service in producing the vermicular movements that are 
essential for the functional activity of such organs as the stomach and inte-tine.

Smooth muscular tisene has a wide distribution in the body. It is fomd in rreatest bulk in the uterus, midlle coats of the arteries and veins, the muscular coats of the stomach and intestine, and the wall of the bladkler; but we shall find it present in greater or less amount in many of the organs, the strueture of which we shall presently have to study.

2. Cardiac Muscular Tissue (Figs: 77 and 78). -The heart-muscle is composed of cells having a general eylindrical form and containing a single (oceasionally, two) nuclens. The nuclens is vesicular, las a distinet reticulum of chromatin, and is usually oval. It is

Fig. 78.

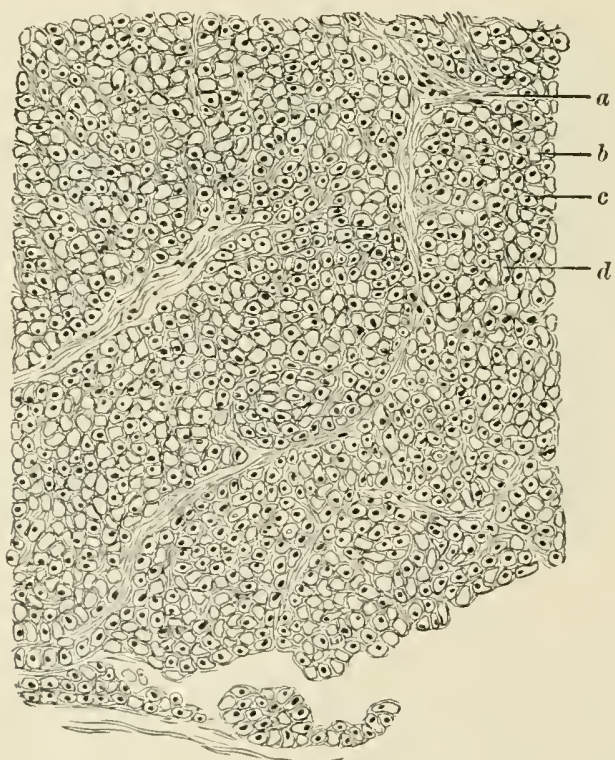

Section of limman heart. The direction of the section is such that the muscular cells are cut exactly perpendicular to their long axes. $a$, intermuscular areolar tissue. From this, more delicate fibrons tissue penetrates between the muscle-fibres forming the muscular bundles, which are imperfectly separated from each other by the broader septa of fibrous tissue. $b$, inuscle-cell cut beyond the nucleus; $c$, cell ent so as to include the nucleus; $d$, cell ent just below a branch. The index line $d$ points to that part of the cell whieh passes into the branch. The granular claracter of the contractile substance when seen in erosssection has been omitterl from the figure. At the lower elge of the figure the section has been torn, lut a small amount of the sulpericardial areolar tissue is represented.

situated near the centre of the ecll, and is surromeded by a small amount of cytoplasm, which is a little mole abundant at the ends of the nucleus. The rest of the eell-borly is composed of contractile 
substance, a molification of the eytoplasm of which the cell was first composed, which presents a fine longitudinal and a somewhat coarser transverse striation due to the arrangement of the "sarcoplasmic disks" of which the contractile substance or sarcoplasm is composed. The proper intercellular substance was formerly regarded as a homogeneous cement, which lay between the ends of the cells, but there appear to be delicate protoplasmic bridges connecting contiguous cells (Figs. 78 and 79). The cells are arranged end to.

FIG. 79.

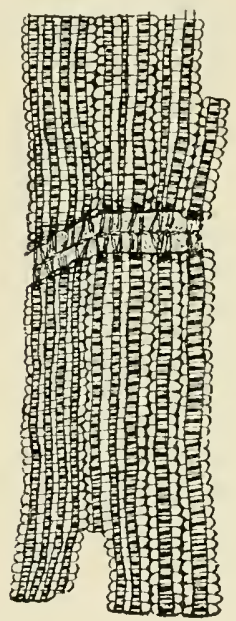

Longitudinal section of adult human heart muscle, showing the junction of two cells. (MacCallum.)
FI(ง. 80 .

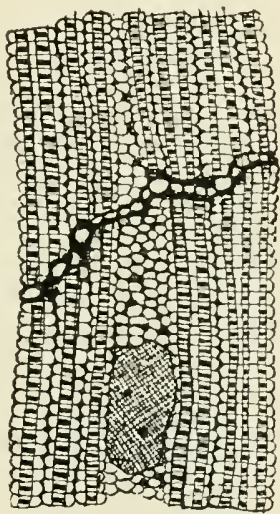

Longitudinal section of heart muscle trom an adult dog, showing protoplasmic bridges between two cells. (MacCallum.)

end so as to form fibres, the lines of junction between them being usually invisihle. The cells give off branches which unite with each other in such a way as to convert the heart-muscle into a reticulum of muscular fibres. The meshes of this reticulum are ocrupied by areolar tissue, in which the vascular and nervous supply of the tissue is situated. Where this tissue is abundant it may also contain a few fat-cells. The carliac muscle-cells are destitute of a cell-membrane, in which respect they differ from the fibres of voluntary striated muscle.

When seen in longitudinal scetion it is difficult to trace a given mucle-fibre for any considerable distance, becanse the occasional anastomosing hranches of the cells cause a blending of the neighboring fibres with each other. In cross-scetion the cells have a 
romnd, oval, or polygonal shape, and vary considerably in size, owing to the branching. Their cut surfaces are dotterl with the minute polygonal cross-sections of the elements of the eontraetile substance, which give the cell its appearance of longitudinal striation. These elements are ealled the "sareostyles."

Cardiac muscle occurs only in the leart. It is not under the control of the will, but differs from the other involuntary muscles in the foree and rapidity of its contractions, which resemble those of the voluntary muscles.

3. Striated Muscular Tissue (Figs. 81-84).-The volnntary muscles have for their characteristic tissue-element greatly elongated, multi-

FIG. 81.

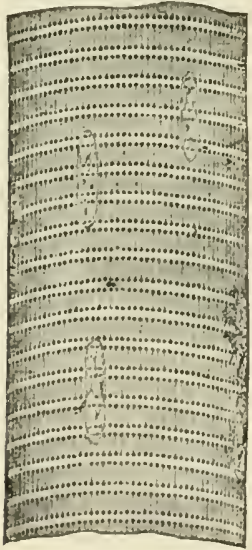

FIf. 82.

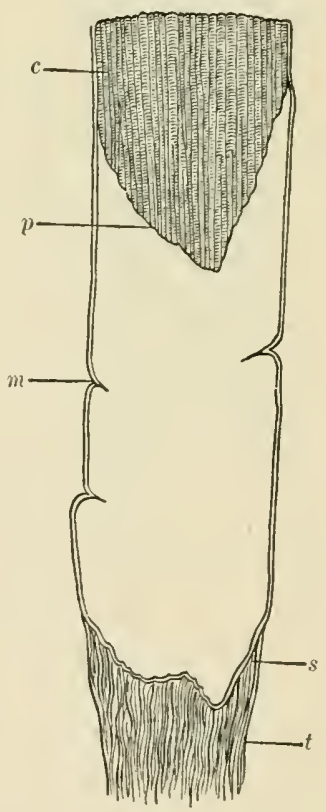

Striated muscular tissue.

Fiti, 81,-Portion of a muscle-fibre from a mammal. (schifer.) This figure represents the appenrances of the fibre when the surface is in sharp focus.

Fic;. 8.,-Termination of a muscle-fibre in tendon. (Jinnvier.) $c$, contractile substance; $p$, retracted end of contractile substance, separated from the sarcolemma during the preparation of the specimen; $m$, sarcolemma, slightly wrinkled; $s$, sarcolemma in contact with fibrous tissue of tendon; $t$, teudon.

nucleated, cylimtrieal cells. The borly of these cells is almost exclusively composed of a very complex, contractile substance which presents both longitudinal and transversestriations, the latter much coarser 
FIr. 83.

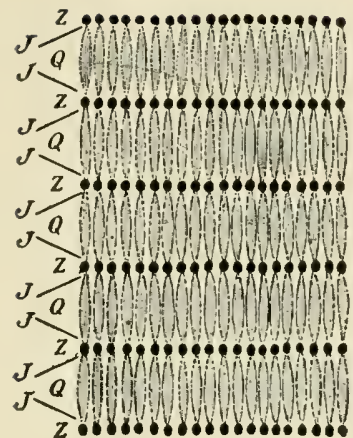

A

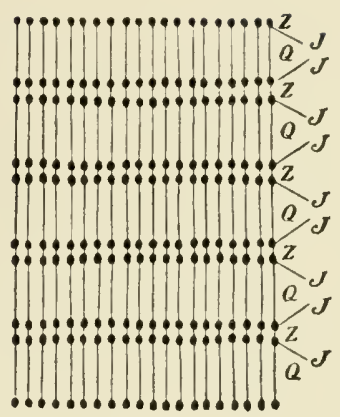

$B$

FIG. 84 .

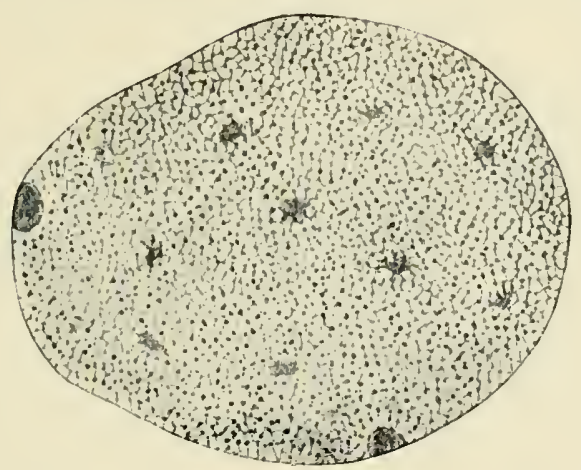

Striated muscular tissue.

FIG. 83.-Diagrams of the structure of the contractile substance. (Rollet.) $Q$, sarcous elements, appearing dark in $A$, light in $B ; Z$ and $J$, sarcoplasm. The sareoplasm also lies between the sarcous elements in $Q$, appearing as light bands in $A$ and as dark lines in $B . A$ is the appearance of the fibre when the focal plane is deep; $B$, the appearance when the focal plane is superficial (see Fig. 81). The dots $Z$ in $A$ and $J$ in $B$ are optical expressions of differences in the refraction of the sarcoplasm and sarcous elements, and do not represent actual structures. A complete explanation of the way in which a microscopical image may contain apparent objects which have no actual existence cannot be entered into here. It is due to the fact that regularly alternating structures of different powers of refraction affect rays of light very much as they are affected by a fine grating, producing diffraction spectra. These spectra may interfere with each other, occasioning an alternation of light and dark lands or areas above the specimen. When the focal plane is changed the light areas become dark and the dark areas light, but sometimes with an alteration in their ontline and relative sizes, as exemplified in the cuts.

Fig, 81.-Cross-section of a muscle-fibre. (Rollet.) The fine reticulım, collected into larger masses at a few points in the midst of the contractile substance, is composed of sareoplasm. The clear areas within this reticulum are the cross-sections of the sarcous elements. These cross-sections are sometimes called "Cohnheim's areas." Immediately beneath the sarcolemma are cross-sections of two nuclei.

and prominent than the former. It must suffice us to consider this contractile substance as made up of a number of prismatic bodies, 
"sarcous dements," which are arranged end to end to form columus, sareostyles, extending parallel to each other, from one end of the eell to the other. The sareous elements of all the sareostyles. lie in planes perpenticular to the long axis of the cell. It is, therefore, possible to separate the contractile substance into a number of tibre-like columns (sareostyles, Fig. 67), made up of sarcous clements attached at their ends, or to split it transversely into. disks composed of sarcons elements lying side by side. Between the sarcous elements is a substance which has received the name. "sareoplasm."

The contractile substance is enclosed in a thin, homogeneous membranous envelope, called the "sarcolemma." The nuclei of the cell lie immediately bencath the sarcolemma, between it and the contractile substance, and are surrounded by a small amount of ummodified cytoplasm.

The muscle-fibres lie parallel to each other and to the general direetion of the muscle which they compose, and are separated by loose areolar tissne, containing their vasenlar and nervons supplies. The areolar tissue between the individual muscle-fibres is called the endomysium and supports an abundant network of eapillary bloodvessels lying parallel to the fibres with numerous transierse anastomoses. Broader septa of areolar tissue divide the whole muscle into fisciculi and support the larger bloodvessels and nerves. There sejta are eollectively known as the perimysimm. Surromeding the whole muscle and continuons with the perimysimm and endomysim is a thicker sheath of fibrous tissue, the epinysium. When ween in cross-section the muscle-fibres are circular or polygonal in form, and the cut surface of the contractile snbstance appears crowded with small polygonal areas, the sections of the sareous elements, between which is the sareoplasm. Where the nnelei are included in the seetion they appear somewhat flattened amb lie at the edge of the contractile substance, where a thin zone of eytoplasm may sometimes be detected around them. The sareolemma which lies ontside of these constiunents of the cell is so thin that it can rarely be distinetly scen.

The muscle-filores are in close contalet at both ends with the dense fibrons tis-ne of the tendons attached to the muccle, or with the periosteal fibrons tissue when the muscle appears to be attached directly to bone-c. g., the seapulae. In most of the voluntary museles there are nceasional groups of small tibres which differ in structure from the majority and appear to be subordinate to and certainly 
form a part of the "musele-spindles," structures that contain nerveendings which have to do with the muscular sense. These musclespindles have not been observed in the pharynx and resophagus or in the muscles of the eye, laryux, and penis. In other voluntary muscles they appear to be present in the proportion of about one spinclle to one hundred muscle-fibres. The muscle-fibres connected with these spindles are grouped in collections of from three to twenty individual fibres. They are much smaller than the ordinary musclefibre and their cross-striations much coarser. They possess a sarcolemma and nuclei situated immediatcly beneath it, but in addition contain oval or round nuclei sitnated in the contractile substance itself. These fibres, sometimes called the fibres of Weismann, pass through the muscle-spindles, so that one may distinguish an intrafusal

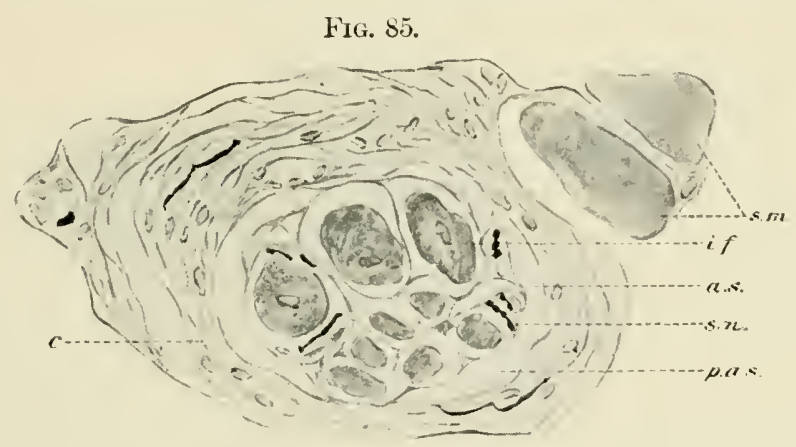

Cross-section of muscle-spindle from plantar muscle of cat: $c$, capsule; $a$, s., axial sheath ;

$i$. $f$., intrafusal fibre with central nucleus; $p . a$. $s$., periaxial space; $s . n$, medullated nerve; s. m., ordinary muscle-fibres. (After Huber.)

portion and extrafusal parts. Toward the centre of the intrafusal part the nuclei within the contractile substance are more abundant than elsewhere and may entirely displace the contractile substance, so that the fibre in this region consists of a sarcolemma so crowded with nuclei that they flatten each other where in contact. The muscle-spindle consists of a capsule, continnous with the general perimysium, which here becomes laminated and much thicker, resembling in structure the outer layers of a Pacinian corpuscle. The sheaths of the nerves which pass into the spindle blend with its capsule, and the nerve-fibres theu branch and form a spiral about the muscle-fibres, often ending in flattened expansions in close connection with the latter. Besides these sensory nerves there are motor nerves ending in motor plates similar to those terminating the motor nerves distributed to the ordinary muscle-fibres (Fig. 85). 


\section{CHAPTER VI.}

\section{TISSUES OF SPECIAL FUNCTION (CONTINUED).}

\section{THE NERVOUS TISSUES.}

The nervous tissues, like the muscles, are tissues of special function, and are composed of highly specialized structures. Of these, only the ganglion-cells, the nerve-fibres, the neuroglia, and a few of

Fig. 86.

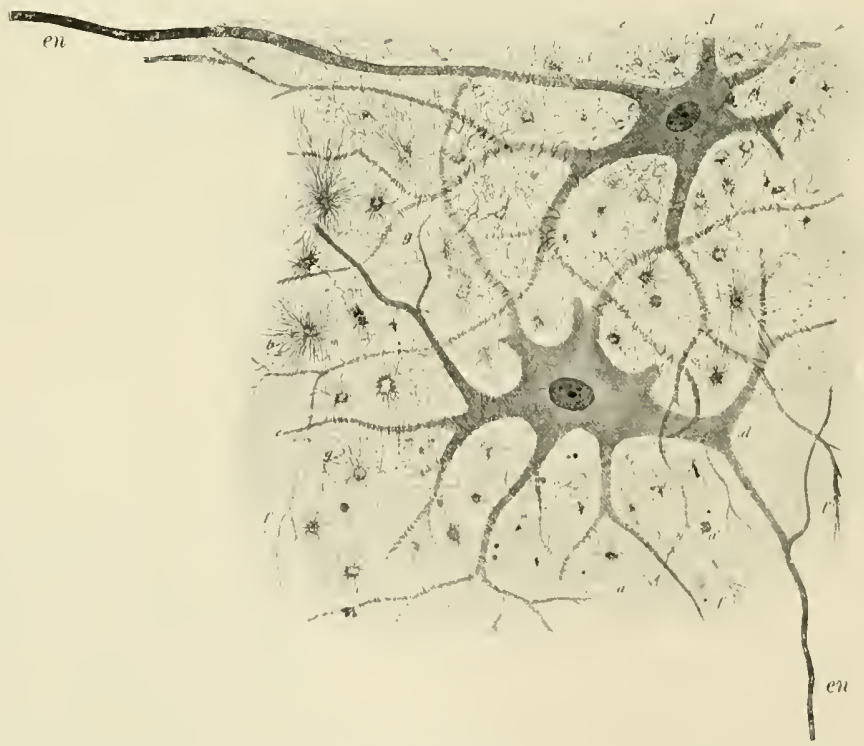

Nerve- and neuroglia-cells from gray matter of spinal eord ; calf. (Lavdowsky.) The figure represents two isolated ganglion-cells, with branching protoplasmic processes, and each with a single axis-eylinder roeess, $e n$. The axis-eylinder process of the lower cell gives off a brauch a short distance from the cell. Between the ganglion-cells are those of the neuroglia. The protoplasmie processes of the nerve-eells subdivide into very delieate fibres, which lie among those of the neuroglia-cells.

the modes of terminal distribution of the nerves will be considered here. 
1. Ganglion- or Nerve-cells (Figs. 86 and $8 \overline{\text { }}$ ).-Nerve-cells vary greatly both in shape and size. They are rich in cytoplasm, and contain an unusually large nucleus, generally spherieal in shape, within the reticulum of which there is nearly always at least one conspicu-

FiG. 87.

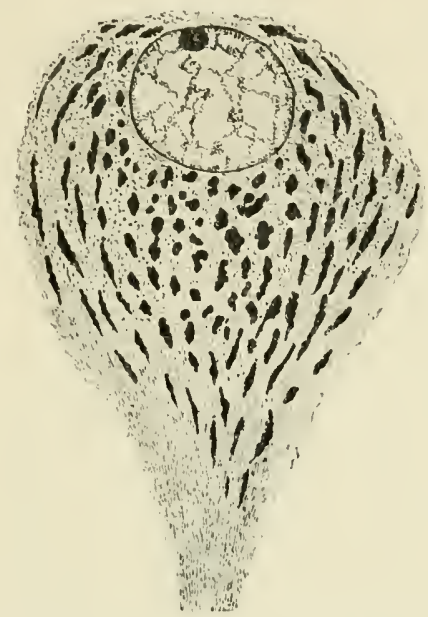

Section of unipolar nerve-cell from gray matter of spinal cord. (Flemming.) This figure shows the fibrillation of the axis-cylinder process and the cytoplasm of the cell, as well as the prominent chromophilic granules in the latter.

ous nucleolus. The cell-bodies may be spherical, ovoid, polyhedral, or stellate in form, and are prolonged into one or more long processes. Some of these taper and branch repeatedly, the ultimate delicate fibrils terminating in free extremities lying in the intercellular substance, "dendritic processes." At least one of the processes emanating from each cell is coarser than these dendritic processes, and is prolonged into a nerve-fibre, forming the essential constituent of that structure. This process is called the "axis-cylinder process." It does not branch as freely as the other processes, but may give off" one or more lateral twigs near its origin.

It is customary to divide the nerve-eells into unipolar, bipolar, and multipolar cells, according to the number of processes proceeding from them. The unipolar cells are connected by their single processes with nerve-fibres, and many of the bipolar cells, which have a fusiform shape, lie in the course of a fibre with which the two processes are contimuons. In such eases one of the 
processes is an axis-cylinder process. The multipolar cells have one axis-cylinder process, the rest being of the dendritic type already mentioned, which are distingnished as "protoplasmic" processes.

Nerve-cells are, as a rule, larger than the other cytoplasmic cells of the borly, with the exception of the larger epithelial cells. Their cytoplasm is so finely granular that the cells look much more transparent than those of epithelinm. With a high power the eytoplism frequently exhibits fine striations, which are prolonged into the processes, giving them an appearance of longitudinal fibrillation. These appearances are dne to the arrangement of the fibrils of spongioplasm. Considerable attention has of late been given to certain granules, which become evident in the cytoplasm when nerve-cells have been fixed in alcohol or in acid solutions. These granules have an atfinity for dyes, "chromophilic granules," and usually occur in groups in the neighborhood of the nucleus. Their significance is not yet understood.

The protoplasmic processes of the nerve-cells diminish in diameter as they branch, and they also present occasional varicositien, which give them an irregular contour. They terminate either in fine-pointed extremities or in little, knobbed ends, and do not unite with those of neighboring cells, but form with them an intricate interlacement of delicate nervous twigs.

The axis-cylinder processes arise in conical extensions of the cell, and then become uniform in diameter and of a smooth contour without varicosities. When they branch the two divisions retain their size thronghont their course until they enter into the formation of some terminal structure.

The arerage size of the nuclei of nerre-cells is greater than that of the other nuclei in the body, hut they appear to contain less chromatin, and therefore stain less deeply and present a less distinct intranuclear reticulum.

Nerve- or ganglion-cells are found in the gray matter of the central nelvols system, in the ganglia, and sometimes in the course of nerves and in their peripheral terminations (Fig. 88).

2. Nerve-fibres.-There are two varieties of nerve-fibres: the white, or medullated, and the gray, or non-medullated. These differ both in their appealanee when seen by the unaided eve and in their microscopical structure.

(a) Medullated nerve-fibres consist of a central cylindrical struct- 
ure running a continuous conrse from the eell giving it origin to the peripheral termination of the nerve, called the "axis-cylinder" ; an external menbrauous envelope, the "neurilemma" ; and a semisolid material, the " myelin," "white substance of Schwann," or " medullary sheath," lying within the neurilemma and surrounding the axis-cylinder.

The axis-cylinder is a greatly elongated process (axis-cylinder process) springing from a nerve-cell. It is marked by longitudinal

FIf. 88 .

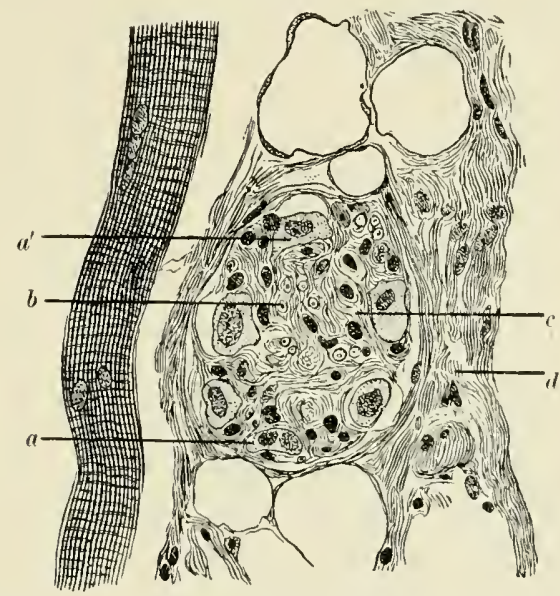

Small ganglion in the tongne of a rabbit: $a, a^{\prime}$, ganglion-cells; $a^{\prime}$, cell, with the beginning of its axis-cylinder process; $b$, medullated nerve-fibre in cross-section; $c$, fibrous tissue within the ganglion (part of this fibrous structure may be composed of non-medullated nerve-fibres); $d$, areolar tissue surrounding the gangliou and containing adipose tissue in the upper and lower parts of the figure. To the left is a striated muscle-fibre. The ganglion is seen in cross-section, so that its connection with the nerves, in the course of which it lies, is not visible.

striations, which appear to represent exceedingly delicate fibrils composing the axis-cylinder. These fibrils frequently separate at the distal extremity of the nerve and take part in the construction of the various forms of nerve-endings. A more minute study of the axis-cylinder leads to the inference that it is composed of spongioplasm, continuous with that of the body of the eell, and that the appearance of longitudinal striation is due to the elongated shape of the spongioplasmic meshwork and the greater thickness, of its longitudinal threads, the transverse threads uniting them being much less conspienous. 
FIG. S9.

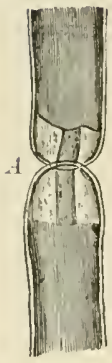

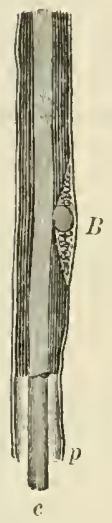

Medullated nerve-fibre. (Key and Retzius.) $A$, node of Ranvier; $B$, nucleus belonging to the neurilemma ; $c$, axis-cylinder; $p$, neurilemma, rendered distinct by the retraction of the myelin of the medullary sheath. In the left-hand figure the elefts of Lanterman are shown as white lines in the dark myelin. These figures are taken from specimens treated with osmic acid, which colors the fatty constituent of the myelin a dark brown or black.
The neurilemma, or external investment of the nerve-fibre, called also the "primitive sheath," or "sheath of Schwann," is a thin, homogeneous membrane enclosing the medullary substance or myelin. At regular intervals, upon the inner surface of the neurilemma, and surromded by a small amount of cytoplasm, are flattened, oval nuclei, which appear to belong to the neurilemma. About midway between these nuclei the nerve-fibre is constricted, forming the "nodes" of Ranvier. The neurilemma appears to pass through these nodes withont interruption, so that the nemilemma of one internode is continuous with that of the adjaeent internodes. At the nodes, and apparently within the neurilemma, is a disk, perforated for the passage of the axis-eylinder, called the "constricting band" of Ranvier. It may be that this band is of the nature of a cement-substance, joining the neurilemma of neighboring internodes; for the latter appear to be developed from cells, probably of mesoblastic origin, which surround the nerve-fibres after their formation, becoming flattened to form membranous investments of the nerve-fibre. If this view be correct, the neurilemma of each internode, with its single nncleus, is to be regarderl as a single, specialized cell, derived from the surrounding eonnective tissues, and serving to protect the nerve-fibre. In perfect harmony with this conception of its nature are the facts that the nerves within the brain and spinal cord are destitute of neurilemma, and that when a nerre-fibre branches in its course the point of division is always at one of the nodes of Ranvier (Fig. 89).

The medullary sheath, or myelin, is a soft material inter- 
posed between the nenrilemma and axis-cylinder. It is not a simple substance, but contains at least one constituent closcly resembling fat or oil in its chemical nature; also a substance chemieally allied to the keratin of horns and the superficial cells of the epidermis, called neurokeratin; and a homogeneous, clear fluid. 'The way in which these constituents are combined is a matter of doubt, the apparent strueture of the medullary sheath varying greatly when different modes of preparing the nerve for mieroseopical study have been employed. But the neurokeratin appears to exist as a delicate reticulum pervading the medullary substance. The medullary sheath appears to be interrupted at irregular intervals by oblique elefts, which surromnd the axis-eylinder like the flaring portion of a funnel. These "Lanterman's" elefts are ocenpied by a soft material, probably similar to that composing the constrieting bands (Figs. 90 and 91).

FIG. 90.

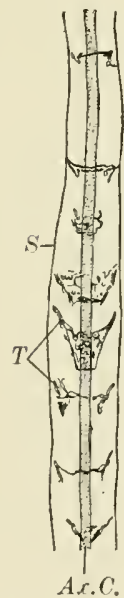

FIG. 91.

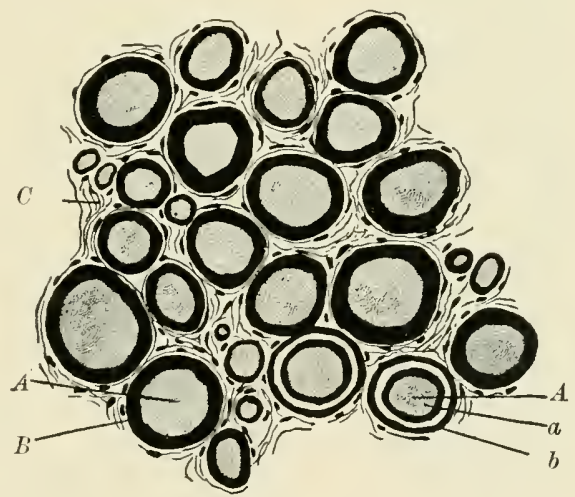

Fig. 90.-Longitudinal view of portion of nerve-fibre from sciatic of dog. (Schiefferdecker.) $S$ neurilemma: $T$, stained substance within the elefts of Lanterman.

Fig. 91.-Cross-section from sciatic nerve of frog. (Bühm and Davidoff.) $A$, axis-eylinder, showing punctate sections of the fibrille: $B$, medullary sheath stained with osmic acid; $a, b$, apparent duplication of the medullary sheath, due to the presence of a Lanterman cleft; $C$, areolar tissue between the fibres.

The medullary sheath is developed after the formation of the axis-cylinder, and is, at first, continuous along the course of the latter. Subsequently it beeomes interrupted at the nodes of Ranvier by the constrieting disk. It seems to be derived from 
the axis-cylinder, and may, therefore, be regarded as a product of that greatly extended arm of the eytoplasm of the nerve-cell.

The amount of medullary substance present in different nerves varies greatly. Sometimes it is so slight as to be hardly distinguishable. In other cases its thiekness considerably exceeds the diameter of the axis-cylinder. It is present within the spinal cord and brain, although not enclosed in neurilemma in those sitnations.

FIG. 92.

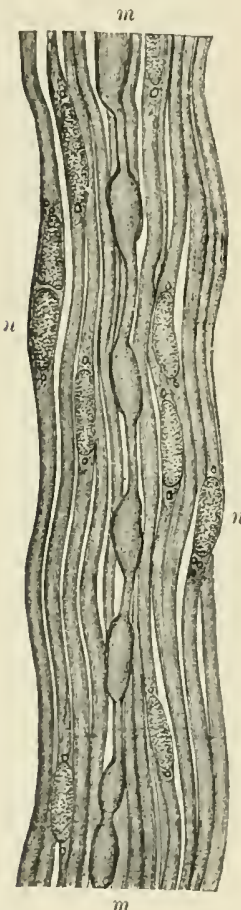

$m$

Nerve-fibres from the sympathetie system. (Key and Retzius.) All the fibres except that marked $m$ are non-medullated. The fibre $m$ has an incomplete medullary sheath. $n, n$, nuelei uf the neurilemma. These are surrounded by at small amount of cytoplasm, which is not elearly represented in the figure.

At the peripheral ends of the nerves, on the contrary, it usually disappears before the neurilemma.

The individual nerve-fibres are isolated only at their extremities. Throughout most of their course they are collected into bundles, forming the "nerves" of the body. Within these bundles the nervefibres are held together by fibrous tisme in the following manner: a delicate areolar tissue containing their vascular supply lies between the individual fibres. This fibrons tissue is called the "endoneurium." The nerve-fibres, thus held together, are aggregated into bundles, called "funiculi," which are surrounded by sheaths of still denser fibrous tissue, rich in lymphatic spaces, which are called the "perineurium." This perineurium on its inner surface becomes continuous with the endonemrium just described. The funiculi, enelosed by their perineurium, are, in turn, held together by an areolar sheath, which has received the name, "epineurium," and forms the onter covering of the nerve.

The funiculi do not rmu a distinct course thronghont the length of the nerve, but give off nerve-bundles, enclosed in perinemium, which join other funienli; the nerve-fibres themselves do not, however, anastomose with each other.

(b) The gray, or non-medullated, nerve-fibres are, as their name implies, destitute of medullary substance. They consist of an axis- 
eylinder, which at intervals appears to be nueleated. These nuclei are presumably constituents of a membranous investment or neurilemma ; but the latter is difficult of demonstration beeause of its thinness and transparency, and its constant presenee is not definitely established (Fig. 92).

Unlike the medullated variety, the gray nerve-fibres frequently give off branches, which join other fibres and constitute true anastomoses.

Non-medullated fibres are most abundant in the sympathetic nervous system, but oecur also in the nerves derived direetly from the brain and spinal cord.

3. Neuroglia.-The nerve-cells and fibres of the central nervous system are surrounded and supported by a tissue which is derived from the epiderm, and is called the "neuroglia." It must be regarded as a variety of elementary tissue having funetions similar to the conneetive tissues, although its origin makes its relations to the epithelial tissues very elose.

Neuroglia eon-ists of cells, the "glia-cells," which vary considerFIG. 93.

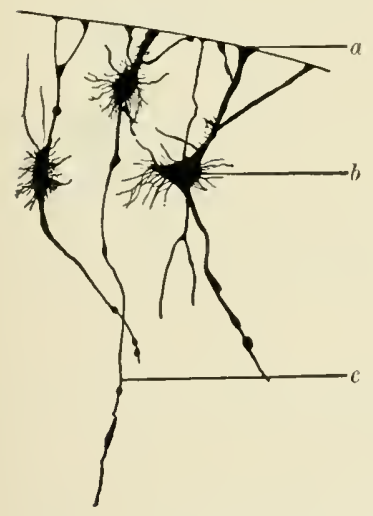

FIt. 94.

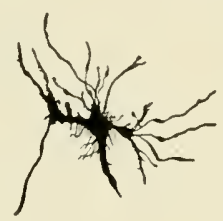

Glia-cells from the neuroglia of the human spinal cord. (Retzius.)

Fig. 93.-Three cells from the anterior portion of the white matter: $\alpha$, processes extending to the surface of the cord; $b$, cell-body; $c$, long, delicate process extending far into the white matter.

Fig. 94.-Two cells from the deep portion of the white matter.

ably in eharacter, and an intereellular substance, which is for the most part soft and homogeneous, resembling in this respeet the cement-substance found in epithelium, but which may, here and there, contain a few delieate fibres, possibly derived from the processes of some of the cells, or possibly of mesolermic origin, and, in eonsequence, belonging to the conneetive tissues. 
The glia-cells possess delicate processes, which lie in the cementor ground-substance and form a felt-like mass of interlacing filaments, but do not unite with each other. Two types of cell may be distinguished, but they are not sharply defined, hecause intermediate forms are met with. In the first type the cells lave relatively large

Fig. 95.

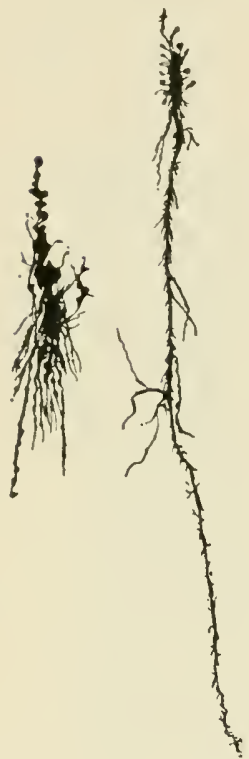

Fig. 96.
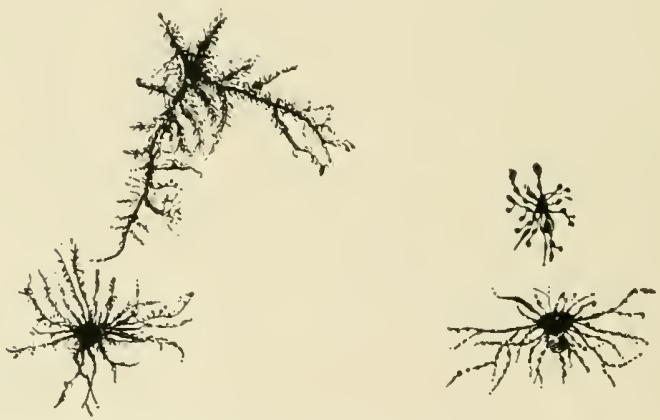

Glia-cells from the human spinal cord. (Retzius.)

Fig. 95-Cells from the substantia gelatinosa Rolandi of the posterior horn. The cell to the right has a long process beset with fine branches.

Fig. 96.-Four cells from the gray matter.

Firs. 93-96 are taken from speeimens stained by Golgi's method, which fails to reveal the internal structure of the cells, but is extremely well adapted to show the shapes of the cells and their extension into fine processes.

bodies, beset with a multitude of comparatively short, very fine, and frequently branching proceses (Figs. 95 and 96). This type is most frequently met with in the gray matter. The second type of gliacell is represented by cells with smaller bodies and longer and somewhat coarser proceses that branch much less freely (Figs.93 and 94). They also often poseess one particularly large aud prominent proeess of greater length than the others. The small bodies of these cells serve to distinguish them from nerve-cells, with which they might otherwise be easily confounded. This type predominates in the white matter.

Aside from the proceses of the glia-cells already mentioned, the 
central nervous system eontains fibrous prolongations of the epithelial cells of the ependyma and central canal of the spinal eord (Fig. 97). Fibrous constituents are also derived from the areolar tissue which extends into the organs of the central nervons system from their fibrous investments, the pia mater, in company with the vascular supply.

The central nervous system, then, consists of a small amount of a ground-substance and a great number of cells, most of whieh possess numerous delicate fibrillar processes which interlace in all directions. Some of these cells are the functionally active elements of the organs, the nerve-cells. Others belong to the sustentacular tissue, and are probably functionally passive, constituting the interstitium. Both kinds of cell are developed from the epiderm, and are therefore genetically closely related to each other.

4. Nerve-endings.-Nerve-fibres terminate in two ways : first, in free ends lying among the elements of the tissnes to which the nerve is distributed; second, in terminal organs, eontaining not only nerve-filaments, but cells which are associated with them to form a special structure. The simplest mode of termination consists in a separation of the minute fibrillæ

FIt. 98.

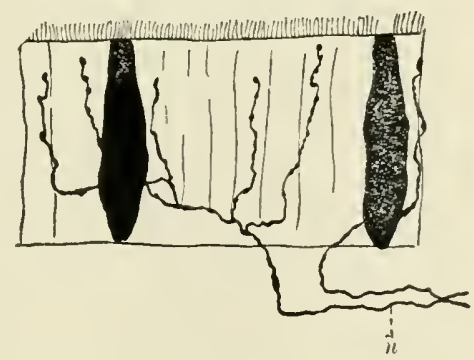

Termination of nerves by free ends. (Retzius.) Nerve-endings among the ciliated columnar epithelium on the frog's tongue. Two goblet-cells, the whole bodies of which are colored black, are represented. The other cells are merely indicated.

composing the axis-cylinders of the medullated fibres, or the chief bulk of the non-medullated fibres, into a number of delicate fila- 
Flc, 99 .

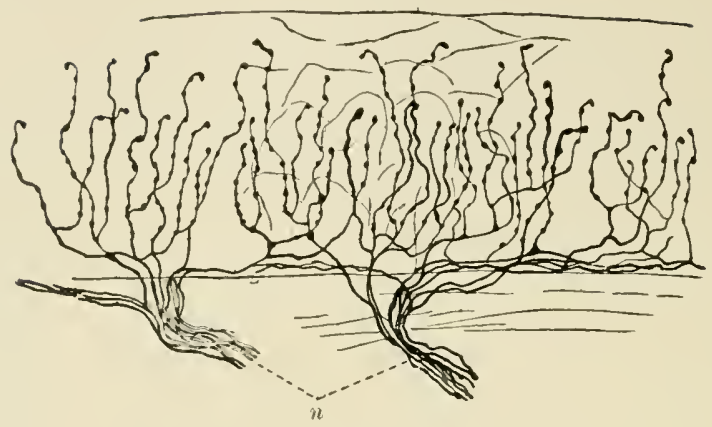

FIG. 100.

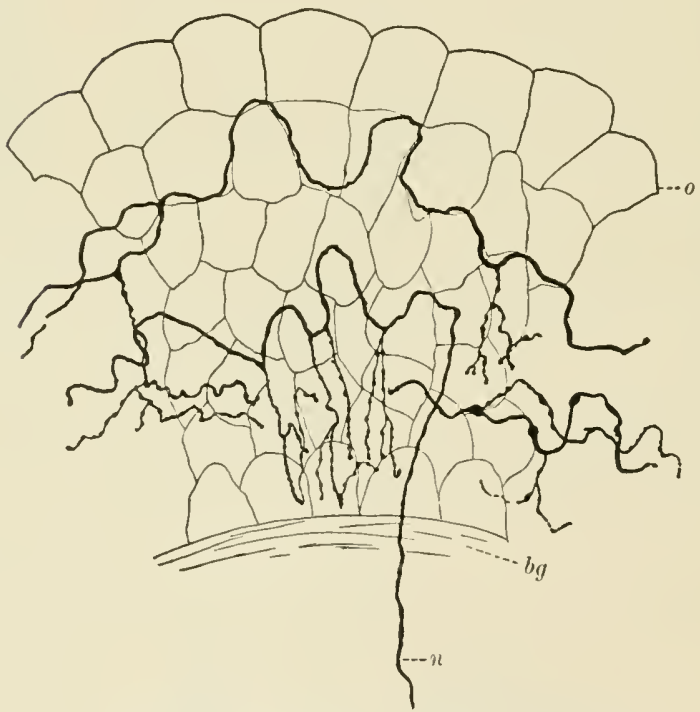

Termination of nerves by free ends. (Retzius.)

Fig. 99.-Two nerves terminating in the stratified epithelium eovering the vocal cords of the cat.

Fig. 100.-Nerve-fibres distributed among the eells lining the bladder of the rabbit; $o$, superfieial layer of the transitional enithelium; $b g$, fibrous tissue underlying the epithelium.

ments, which branch and finally end among the tissue-elements to which the nerve is supplied. The filaments often present small varicosities, and sometimes end in slight enlargements corresponding to one of those swellings. In other cases the terminations are filiform (Figs. 98-100).

A more complex mode of termination is that exemplified in the "motor-plates" of the striated muscle-fihre. Here the axis-eylinder 
divides into coarse extensions, which form a network of broad varicose fibres, lying in a finely granular material containing two sorts of muclei. This whole structure lies in close relations to the contractile substance of the musele-fibre, but whether it is covered by the sarcolemma or not is a matter of doubt. The nuclei in the motor-plate are derived in part from the muscle-fibre, from the cytoplasm of which the granular material surrounding the nerve-

Fig. 101

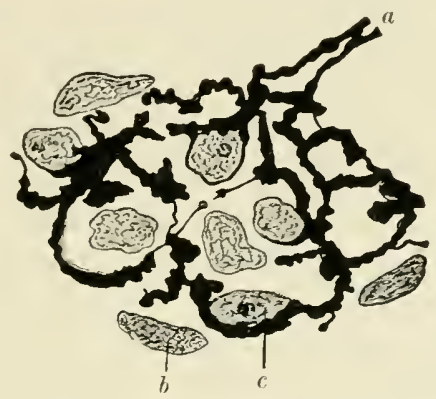

Motor-plate. Tail of a squirrel. (Galeotti and Levi.) $a$, two branches of axis-cylinder terminating in a plexus of varicose filaments ; $b$, muscle-nucleus ; $c$, nucleus derived from neurilemma. The finely granular substance surrounding these structures has been omitted.

endings appears to be derived, in part from cells similar to those forming the neurilemma, which participate in the production of the motor-plate (Figs. 101 and 102).

Fis. 102.

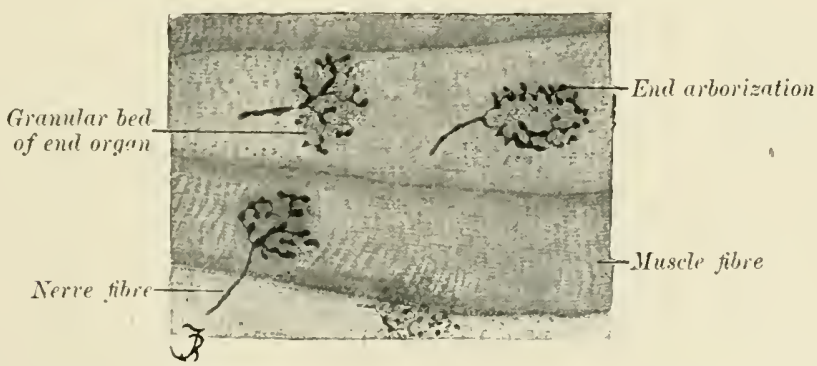

Motor nerve-endings in the fibres of a rat's abdominal muscle. In the upper fibre two endplates are to be seen.

The nerves of sensation, like those supplying the striated muscles, end in bodies in which the nervous terminations are associated with cellular structures of peculiar form. Their consideration will be postponed until the structure of the nervous system is described. 


\section{CHAPTER VII.}

\section{THE ORGANS.}

Is the lowest order of animals, the protozoa, the single cell, which constitutes the whole individual, performs all the functions necessary to the life of the animal; but in the higher multicellular animals, the metazoa, those functions are distributed among a number of different but definite structures, called organs, each of which is composed of certain of the elementary tissues arranged according to a definite and characteristic plan peculiar to the organ.

Within each organ certain of the elementary tissues are charged with the immediate performance of the function assigned to that organ. These tissues are collectively termed the parenchyma of the organ. Thus, for example, the epithelium entering into the composition of the liver and doing the work peculiar to that organ, constitutes its parenchyma. The parenchrma of the heart is its muscular tissue, through the activity of which it is enabled to contract upon its contents.

Functionally ancillary to its parenchyma, each organ possesses a variety of elementary tissues, some of which belong to the connective-tissue group, which serve to hold the tissue-elements of the parenchyma in position, to bring to them the nutrient fluids necessary for their work, and to convey to them the nervous stimuli which excite and control their functional activities. These subsidiary tissues are collectively known as the interstitium of the organ. For example, the fibrous tissue and the elementary tissues forming the bloodvessels, lymphatics, and nerves of the liver, or of the heart, form the interstitia of those organs.

Two sets of structures entering into the formation of the interstitia of the organs-namely, the nerres and the vessels, including those which convey blood and those through which the lymph circulates-have a similar general structure in all the organs, and are connected with each other throughout the body, forming "systems." These systems serve to bring the various parts of the body, so diverse in structure and function and yet so interdependent upon 
each other, into that intimate correlation that makes them subordinate parts of a single organism.

Through the medium of the eireulatory system the exchanges of material essential to the well-being of each organ and of the whole body are made possible, and through the nervous system the activities of the different parts of the body are so regulated that they work in harmony with each other and respond to their collective needs.

Because of their wide distribution throughout the body, we can hardly study any struetures which are not in intimate relations with both ressels and nerves. It will, therefore, be well to consider the structure of the cireulatory system before proceeding to a study of other organs. The study of the nervous system must, because of its complexity, be deferred. 


\section{CHAPTER VIII.}

\section{THE CIRCULATORY SYSTEM.}

THE eirculatory system is made up of organs which serve to propel and convey to the varions parts of the body the fluids through the medium of which those parts make the exchanges of material incident to their nutrition and functional activities.

For some of these exchanges it appears necessary for the cirenlating fluids to come into the most intimate contact with the tissneelements; to penetrate the interstices of the tissues and bathe their structures. For mechanical reasons these fluids must circulate slowly and consume a considerable time in traversing a relatively short distance. Such a suggish eurrent could not avail for the transportation of oxygen from the lungs to the tissnes, and we find that the cireulatory system is divided into two closely related portions: the hrmatic eireulation and the lymphatic cireulation. The former is rapid, and the circulating fluid is the bloot, the red corpuseles of which serve as carriers of oxygen. The latter is slow, and the circulating fluid, called "lymph," is derived from the liquid portion of the blood ("the plasma"). The blood is confined within a system of elosed tubes, the bloodvessels; but the lymph, when first produced by transudation through the walls of the blood vessels, is not enclosed within vessels, but permeates the tissues or enters minute interstices between the tissue-element: surrounding the bloodvessels. Thenee it gradually makes its way into larger spaces-lymph-spaces - which open into the thin-malled ressels constituting the radieles of the lymphatic vasenlar system. These smaller lymphatic vescols join each other to form larger tubes, which finally open into the venom: portion of the hrmatic circulation, thus returning to the blood the lymph which has made its way through the tissues.

The circulating fluids are ke'pt in motion ehiefly by the pumping action of the heart, which forces blood into the arteries, whence it passes through the eapillaries into the voins, and thence back to the heart. During its passage through the smaller arteries, the eapil- 
laries, and the smaller veins, a part of the plasma of the blood, somewhat modified in composition, makes its way through the vascular walls, partly by osmosis, partly by a sort of filtration, and becomes the nutrient lymph of the tissues. The composition of this lymph varies a little in the different parts of the body, and this variation is attributed to some kind of activity, allied to secretion, on the part of the cells lining the vessels.

The larger veins are provided with pocket-like valves, which collapse when the blood-current is toward the heart, but which fill and occlude the veins when, for any reason, the current is reversed. When, therefore, the muscles contignous to the larger veins thicken during contraction and press upon the veins the effect is to urge the blood within them in the direction of the heart. This accessory mode of propulsion matcrially aids the heart, especially during active exercise, when the muscles are in need of an abundant supply of oxygen.

The large lymphatic vessels are similarly provided with valves, and valves guard the orifices by which the lymphatic trunks open into the veins. But the chicf reason for the flow of the lymph appears to be the continuous formation of fresh lymph, which drives the older fluid before it-the so-called ris a tergo.

For convenient deseription we may divide the vascular organs into the heart, arteries, veins, capillaries, and lymphatics.

1. The heart is covered externally by a nearly complete investment of serous membrane, the epicardium, which is a part of the wall of the perieardial serons cavity. Its free surface is covered with a layer of endothelium resting upon areolar fibrous tissue, and containing a variable amount of fat.

The substance of the heart is made up of a series of interlacing and conneeted layers of cardiac muscular tissue, separated by layers of areolar tissue, which extends into the meshes of the muscle, forming the interstitial tissue of the heart. The fibres in the different layers of muscle run in different directions, so that sections of the wall of the heart show the individual muscle-cells cut in various ways.

The areolar tissue is more abundant and denser near the orifices of the heart, and at the bases of the valves merges into dense fibrons rings, which send extensions into the eurtains of the valves, increasing their strength and giving them a firm connection with the substance of the organ. In the centre of the heart, between 
the auriculo-ventricular orifices and the aortic orifice, this fibrous tissue is reinforced by a mass of fibro-cartilage.

The cavities of the heart are lined by the endocardium, consisting of endothelium resting on areolar tissue. The deeper portions of the epi- and endocardium merge with the areolar tissne of the body of the heart. Smooth muscle-fibres are of occasional occurrence in the deeper layers of the endocardium.

The anrieles and the basal third of the ventricles contain ganglia, connected on the one hand with the nerves received by the heart from the cerebro-spinal and sympathetic systems, and on the other hand with a nervous plexus which penetrates the substance of the heart and gives off minute nerrous fibrille to the individual cells of the cardiae muscle. These fibrillie end in minute enlargements connected with the surfaces of the muscle-cells. Many of the ganglia lie beneath the epicardium or in the areolar or adipose tissue situated in its deeper portions.

The valves of the heart are composed of fibrous tissue, continuous with that forming the rings around the orifices. Their surfaces are covered by extensions of the endocardium, except the outer surfaces of the pulmonary and antic valyes, which are corered by extensions of the not dissimilar inner coats of the pulmonary artery or aorta. The fibrous substance of the valvular pockets of those two valves are further strengthened by tendinous strips of fibrous tissue at their lines of contact when the valves are closed. The curtains of the aurieulo-rentrienlar valves are also reinforeed by fibrons tissue derived from fan-like expansions of the chordæ tendineæ.

2. The Arteries.-It will be best to consider first the structure of the smaller arteries, because the individual coats are less complex in these than in the larger arteries.

The arterial wall consists of three coats: the intima, or internal coat; the media ; and the adrentitia, or external coat (Fig. 103).

The intima consists of three more or less well-defined lavers. These are, from within outward: 1 , a single layer of endothelium; 2, a layer of delicate fibrous tisue containing branching cells; 3 , a layer of elastic fibrous tissue. The endothelial layer consists of cells, usually of a general diamond shape, with their long diagonals parallel to the axis of the ressel they line. When the resel expands these cells broaden somewhat and appear very thin. When 
the vessel is contracted they are thicker and the portion containing the mucleus projects slightly into the lumen of the vessel.

The subendothelial fibrous tissue forming the second layer of the intima is composed of very delicate fibrils, closely packed together, with a little cement between them, and enclosing irregular spaces in which the branching cells of the tissue lie. Elastic fibres, spring-

FIG. 103.

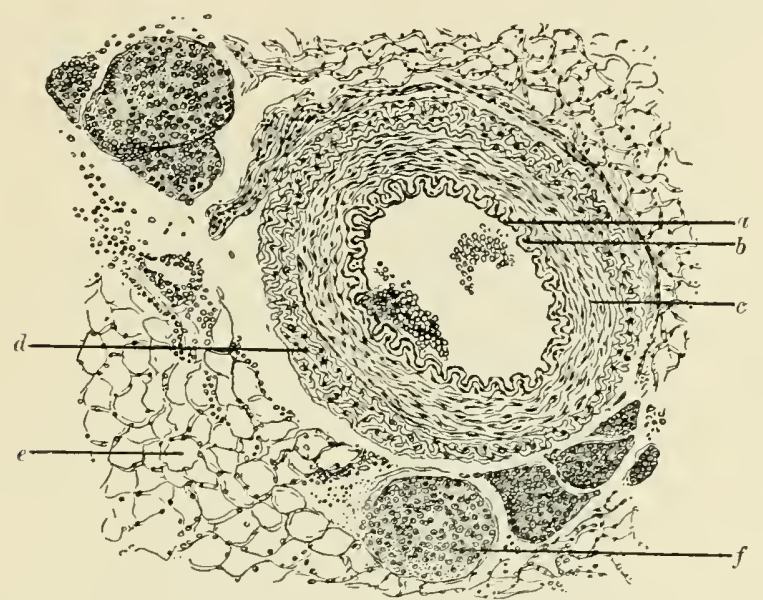

Branch of splenic artcry of a rabbit: $a$, internal endothelial surface of the intima; $b$, elastic lamina of the intima (fenestrated membranc, see Fig. 61); $c$, media composed of smooth muscular tissue encircling the vessel and therefore appearing in longitudinal section with elongated nuclei; $d$, adventitia of fibrous tissue blending above and to the left with the surrounding areolar tissue; $e$. adipose tissue, between the cells of which a few lincs of red corpuscles reveal the presence of capillary bloodvessels; $f$, small nerve, containing both medullated and pale or non-medullated nerve-fibres. There are other similar sections of nerves in the figure. To the left of the artery the section is slightly torn, the adipose tissue being separated from the adventitia of the artery. A few red blood-corpuscles have been extravasated near the nerve at the upper left corner of the figure. There are also a few corpuscles within the lumen of the artery.

ing from the external layer of the intima, may here and there, especially in the larger arteries, make their way into the subendothelial layer.

The elastic lamina of the intima is formed by a network of anastomosing elastic fibres, having a general longitudinal disposition with respect to the axis of the vessel. The spaces left between the fibres of this network vary considerably in size. Where they are smali and the fibres between them are correspondingly broad this layer has the appearance of a perforated membrane (the fenestrated membrane of Henle). Even where this membranous character of the elastic layer is well developed, elastie fibres are given off from its 
surfices and enter the subendothelial layer on the one side and the median eaat of the artery on the other.

The tunica media, or midlle coat of the arteries, consists essentially of smooth musenlar tissue, with the eells arranged transversely to the long axis of the vessels, so that by their contraction they serve to diminish the calibre of the arteries.

The adventitia is an external sheath or layer of fibrous tissue

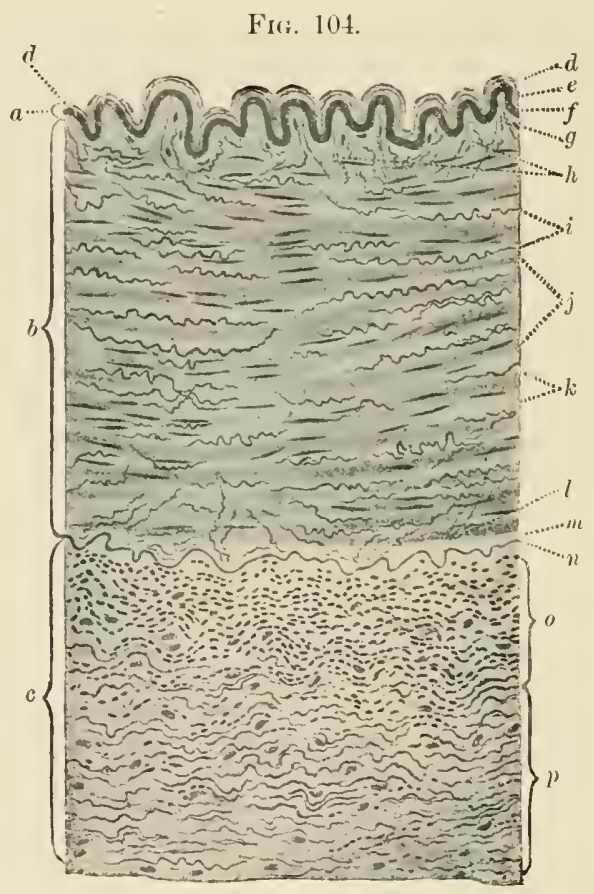

Portion of a transverse scction of a human lingual artery from an adult. (Grünstein.) $a$, intima ; $b$, media ; $c$, arlventitia ; $d$, endothelium; $e$, subendothelial stratum (delicate a reolar tissue); $f$, tunica elastica in terna (fenest rated membrane belonging to the intima): $g$, stratum subelasticum containing elastic fibres $(h)$ that pass from the fenestrated membrane into the media; $i$, concentrie elastic fibres within the media; $j$, smooth museular fibres of media with elongated nuclei; $k$, white fibrous tissue in media; $l$, elustic fibres radiating from the media into the external elastic tunic; $m$, stratum submusculare (areolar fibrous tissue); $n$, tunica elastica externa ; $o$, stratum elasticum longitudinale (fibrous tissue containing elastic fibres running parallel with the axis of the vessel): $p$, stratmm elasticum concentricum (fibrous tissue containing elastic fibres encircling the vessel). The vasa vasorum supplying the tissues of the vaseular wall are not represented.

which merges with the areolar tissue of the parts surrounding the arteries and serves to support the latter without restrieting the mobility necessary for their functional activity. 
In the larger arteries the muscle-filires of the media are grouped in hundles, which are separated by white and elastic fibrous tis-ne (Fig. 104). The muscle-fibres themselves are less highly developed than in the smaller arteries, so that the ressels are less eapable of contracting, but are more highly elastic, beeause of the greater abundanee of elastic fibres. In these larger arteries the boundary between the medial and the intima is less sharply defined than in the smaller arteries, the elastic tissues of the two coats being more or less continuous. In cross-sections of the smaller arteries this boundary is very clearly seen, the elastic lamina of the intima appearing as a prominent line of lighly refracting material, which assumes a wary course around the artery when the latter is in a contracted state. In such sections the nuclei of the endothelial layer of the intima appear as dots at the very surface of the intima.

3. The Capillaries (Fig. 25).-As the arteries divide into progressively smaller branches the walls of the latter and their individual eoats become thinner. In the smallest arterioles the elastic tissue of the wall entirely disappears, and the museular coat becomes so attenuated that it is represented by only a few transverse fibres partially encircling the ressel. These in turn disappear, and the branches of the vessel then consist of a single layer of endothelium continuons with that lining the intima of the larger vessels. These thinnest and smallest vessels are the eapillaries. They form a network or plexus within the tissues, and finally discharge into the smallest veins the blood they have received from the arteries. It is ehiefly through the walls of the capillaries that the transudation giving rise to the lymph takes place, but some transudation probably also occurs through the walls of the smaller arteries and veins.

4. The veins closely resemble the arteries in the structure of their walls, but relative to the size of the vessel the wall of a vein is thinner than that of an artery. This is chiefly hecause the media is less highly developed. The elastic lamina of the intima is also thinner in veins than in arteries of the same diameter.

The valves of the veins are transverse, semilunar, pocket-like folds of the intima, which are strengthened by bands of white fibrous tissue lying between the two layers of intima that form the surfaces of the valves. The valves usually occur in pairs, the edges of the two coming into contact with each other when the valvular pockets are filled by a reversal of the blood-current. 
Behind each valve the wall of the rein bulges slightly. Single valves of similar strueture not infrequently guard the orifices by which the smaller veins discharge into those of larger size.

5. The Lymphatics. - The lymph at first lies in the minute interstices of the tissnes surronnding the hlondvessels from which it has transuded. In most parts of the body those tissues are varieties of fibrous connective tissue, and contain not only the small crevices between their tissue-elements, but larger spaces also, which have a more or less complete lining of flat endothelial eells, but permit the access of lymph to the intercellular interstices of neighboring tissues. The lymph finds its way into these "lymph-spaces," and thence into the lymphatic vessels. These begin either as a network of tubes with endothelial walls, or as vessels with blind ends, and have a strueture similar to that of the blood-capillaries. They are larger, however, and are provided with valves. By their union larger vessels are formed, resembling large veins with very thin and transparent walls, consisting of intima, media, and adventitia. These finally unite into two main trunks, the thoracic duet and the right lymphatic trunk, which open into the subclavian veins. Valves are of mueh more frequent occurrence in the lymphatic vessels than in the veins, but their structure is the same.

In its passage through the lymphatic circulatory system the lymph has oceasionally to traverse masses of reticular tissue eontaining large numbers of ly'mphoid cells, called "lymph-glands."

That portion of the lymphatie system which has its origin in the walls of the intestine not only receives the lymph which transudes through the bloodvessels supplying that organ, but takes up also a considerable part of the fluids absorbed from the contents of the intestine during digestion. Mixed with this fluid is a variable amount of fat, in the form of minute globules. These globules give the contents of these lymphaties a milky appearance, and the ressels of this part of the lymphatic system have, therefore, received the name "lacteals." They do not differ essentially from the lymphaties in other parts of the body.

Lymph-glands. - It is a misnomer to call these structures glands, for they produce no sccretion. A better term is "lymph-nodes."

The lymph-nodes are bodies interposed in the course of the lymphatic vessels through which the lymph-eurrent passes. Their essential eonstitnent is lymphadenoid tissue.

Each node has a splerieal, ovoid, or reniform shape, with a de- 
presion at one point, called the "hilus." It is invested by a fibrous capsule, which is of areolar character externally, where it connects the node with surrounding structures, but is denser, and frecuently reinforced by a few smooth muscular fibres internally. Extensions from this capsule penetrate into the substance of the node, forming "trabecule," which support the structures making up the body of the node.

The lymphadenoid tissue occurs in two forms : first, as spherical masces, "follicles," lying toward the periphery of the node, except at the hilus, and constituting the "cortex" (Fig. 105); second, in the

FIG. 105 .

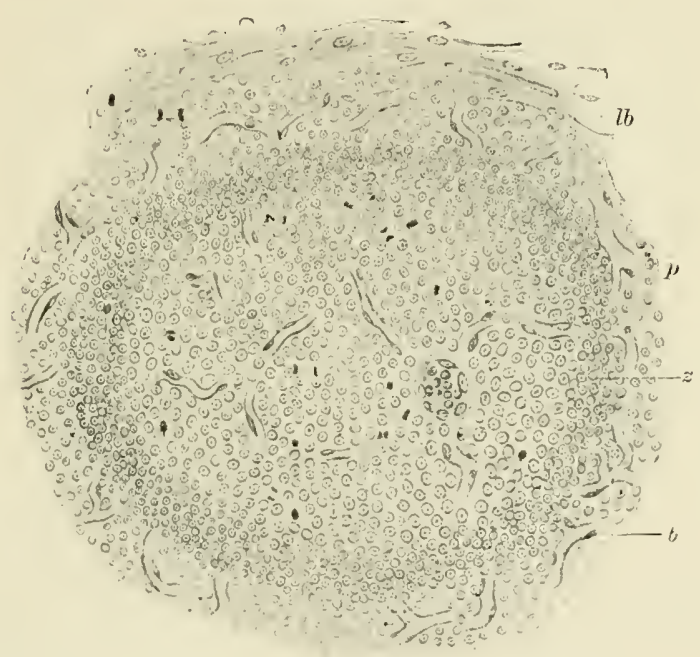

Single lymph-follicle from a mesenteric node of the ox. (Flemming.) $l b$, wide-meshed lymphatic sinns at periphery of the follicle. Between this and the peripheral zone of the follicle $z$, and within the follicle, the retieulum of the sinus and that supporting the cells and vessels of the folliele are not represented. The cells are merely indicated by their nuclei, the cytoplasm being 'omitted. z, peripheral zone of the folliele, marked by a elose aggregation of small lymphoid celis; $p$, more scattered eells outside of the peripheral zone and at the edge of the lymph-sinus. Within the zone $z$ is the germinal centre of the follicle, in which numerous karyokinetic figures arepresent, demonstrating the aetive proliferation of the cells in that region. Two such figures are also represented within the lymph-sinus at the upper left corner. $b$, bloodvessels.

form of anastomosing strands, which makes a coarse meshwork of lymphadenoid tissue in the medullary portion of the node (Fig. 106). The trabecule springing from the capsule penetrate the substance of the node between the follicles in the cortex, and then form a network of fibrous tissue lying in the meshes of the medullary lymphadenoid tissuc, after which they become continnous with the mass 
of fibrous tissue at the hilus and, through it, with the eapsule at that point.

The lymphatic vessel connected with the node divides into it number of branches, the "afferent vessels," which penetrate the capsule at the periphery and open into a wide-meshed reticular tissne lying between the trabecula and the lymphadenoid tissue of the follieles and the medullary strands. This more open reticular tissue, through which the lymph cireulates most freely, forms the

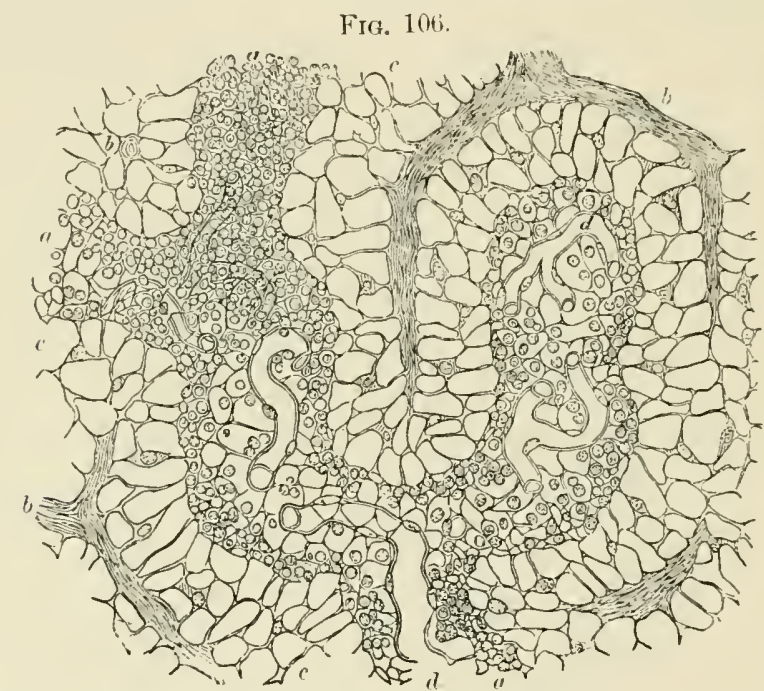

Portion of the medulla of a lymph-node. (Recklinghausen.) $a, a, a$, anastomosing columns of lymphadenoid tissue; $b$, anastomosing extensions of the cortical trabeculæ; $c$, lymphsinus; $d$, capillary bloodvessels. The lymphoid cells in the sinus are not shown.

"lymph-sinuses" of the node, and is less densely erowded with lymphoid cells than the reticular tissue of the follicles and medullary lymphoid tissue. The walls of these sinuses, which are turned toward the fibrons tissue of the trabeculæ and their extensions in the medullat, are lined with endothelium, and a somewhat similar, but probably much less complete, lining may partially separate the sinuses from the lymphadenoid tissue. However this may be, it is certain that lymphoid cells can freely pass from the lymphoid tissue into the sinuses, or in the reverse direction, and that there is a reatly interchange of fluids between the two.

From the sinuses the lyuph passes into a single vessel, the "efferent vessel," through which it is conveyed from the node at the hilus.

The arteries supplied to the lymph-node may be divided into two 
groups: first, small twigs which enter at the periphery and are distributed in the capsule and filorous tissnes of the trabecula and the merlulla; and, seeond, arteries which enter at the hilus, pass through the sinuses, and are distributed in the lymphadenoid tissue of the medulla and cortex. The veins follow the courses of the corresponding arteries. The nerve-supply is meagre, and consists of both medullated and non-medullated fibres. Their mode of termination is not known.

In the centre of the follicles the reticular tissue is more open and the lymphoid eells less abundant than toward the periphery. Mitotic figures are of frequent aceurrence in lymphoid cells in this region, and it is evidently a situation in which those cells actively multiply. Further toward the periphery the reticular tissue is closer and very densely picked with small lymphoid cells, to become more open again and freer of cells as it passes into the reticulum of the sinus (Fig. 107). This last reticu-
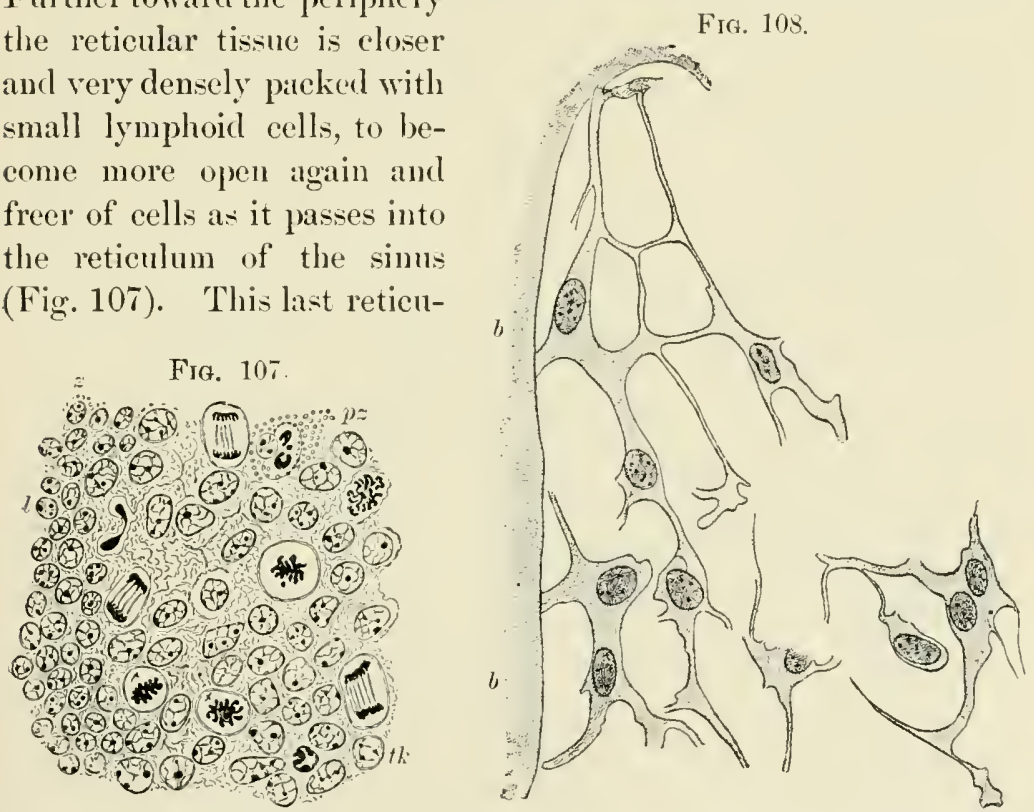

Fig. 107.-Portion of lymph-follicle from mesentery of ox. (Flemming.) $z$. peripheral zone of small, closely aggregated lymphoid cells. To the right of these is a portion of the germinal centre of the follicle, with larger cells, many of which are dividing. Opposite $l$ is a cell executing amceboid locomotion. $p z$, pigmented cell, which has taken upcolored granules from outside; $t k$, dark chromophilic body, the nature of which bas not been determined. Such bodies occasionally occur in lymph-nodes, but their origin and sig nificance are unknown.

Fig. 108.-Section of a small portion of the reticulum of the sinus in a human mesenteric node. (Saxer.) b, b, diagrammatic representation of a portion of the neighboring trabecula.

lum becomes continnous with delicate fibres given off from the tissues of the eapsule and trabeculæ (Fig. 108). The distribution 
of the lymphoid cells gives the follicles a general concentric appearance.

The lymph-follieles of the cortex not infrequently blend with each other, and the activity of the cellular reproduction in their centres varies considerably and is sometimes entirely wanting, when the eoneentric arrangement of the cells disappears.

The structure of the lymph-nodes canses the lymph entering then to traverse a series of chamels, the "sinmes," which, in the aggregate, are much larger than the combined lumina of the vessels supplying them. The velocity of its eurrent is, therefore, greatly redueed, and it remains for a considerable time subjected to the action of the lymphoid cells in and near the sinuses. Small particles which may have gained access to the lymph in its course through the tissues are arrested in the lymph-modes, and are either consumed by phagoeytes-i. e., cells possessing the power of amceboid movement and capable of incorporating foreign substances-or are eon-

FI(i. 109.

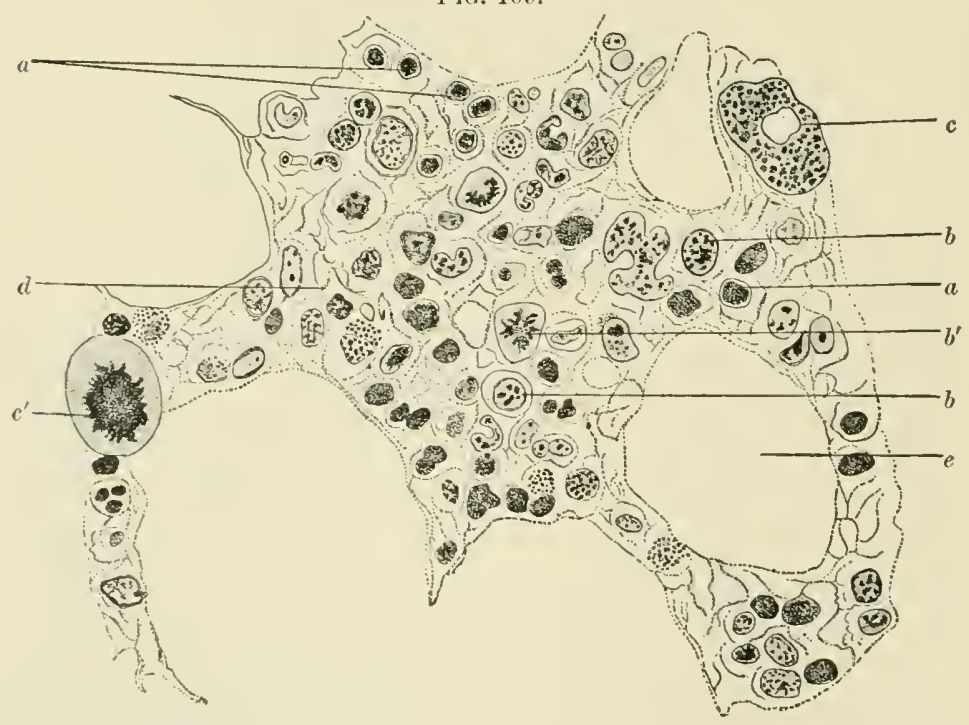

Section of red marrow; human. (Bihm and 1)avidoff.) $a, a$, erythroblasts; $b, b$, mytoeytes; $b^{\prime}$, myelocyte undergoing division : $c$, giant-cell with a single nucleus; $c^{\prime}$, giant-cell with diviling nucheus: $a$, reticulum; $c$, spuce occupled ly a fat-cell (not represented); $f$, granules in a portion of an acidophilic cetl.

veyed into the marninal portions of the follicles, where, if insusceptible of destruetion, they remain. It is in consequence of this process that the lymph-nodes conneeted with the bronchial system 
of lymphaties are blackened as the result of an accumulation of particles of earbon that have been inhaled and then absorbed into the lymphatics.

The lymph-nodes may, therefore, be considered as filters which remove suspended foreign partieles from the lymph; but it is probable that the dissolved substances in the lymph are also affected in its passage throngh the nodes, and that a purification of that fluid is thereby oceasioned. A fiesh aceess of leucreytes further alters the character of the lymph during its transit through the lymph-nodes.

Bone-marrow (Fig. 109).-In early life the medullary cavities of the long bones, as well as the cancellæ of the spongy boues, are all occupied by that form of marrow known as "red" bone-marrow. This is functionally the most important variety. In after-life the marrow in the medullary eavities of the long bones becomes fatty throngh infiltration of its cells with fat, which converts them into cells quite similar to those of adipose tissue. Marrow so modified is called "yellow" marrow. It may subsequently undergo a species of atrophy, during which the fat is absorbed from the cells and the marrow becomes serous, fluid taking the place of the materials that have been removed. This process results in the production of a "mucoid" marrow.

The marrow of bones possesses a supporting network of reticular tissne not mulike that of the lymph-nodes. In the meshes of this tissue are five different varieties of cell (Fig. 110): First, myelocytes, cells resembling the lencocytes of the blood, but somewhat larger in size and possessing distinctly vesicular nuclei. They are capable of amoboid movements, and not infrequently coutain granules of pigment which they have taken into their cytoplasm. Second, erythroblasts, or nucleated red blood-corpuscles, which divide by karyokinesis and eventually lose their nuclei, becoming converted into the red corpuseles of the circulating blood. Third, acidophilic cells, containing relatively coarse granules having an affinity for "acid" anilin-dyes, snch as eosin. These cells are larger than the majority of the lencocytes circulating in the blood. Their nuclei are spherical or polymorphic and resicular. Fourth, giant-cells with unusnally large bodies and generally several nuclei, though oceasionally only one nuclens is present. They possess the power of executing amceboid movements and appear to act as phagocytes. Where absorption of bone is taking place they are found 
elosely applied to the hone that is being removed, and have in this situation been ealled "osteoclasts." Fifth, basophilie cells, or plasmacells, the eytoplasm of which contains granules having an affinity

Fir. 110.
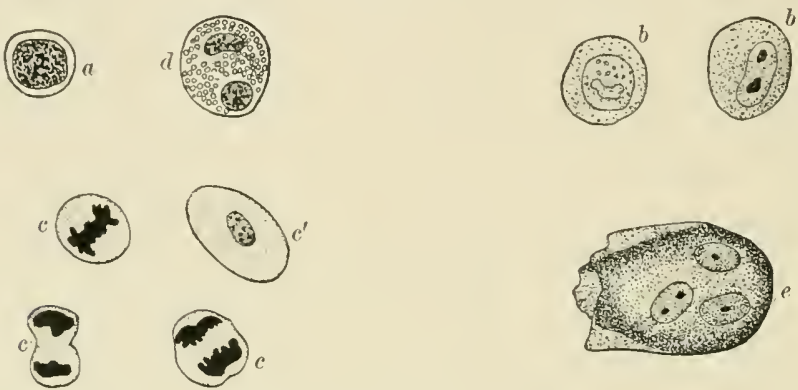

Cells from bone-marrow: $a$, small leucocyte from circulating blood, with highly chromatic nucleus and slight amount of cytoplasm, a "lymphocyte" probably derived from a Iympnode; $b, b$, myelocytes, larger than $a$, with resicular nuclei; $c, c$, $c$, erythroblasts, with nuclei in karyokiucsis; $c^{\prime}$, mature red corpuscle (erythrocyte); $d$, acidophile (eosinophile) leucocyte. The basophilic leucocytes, or plasma cells, resemble this, but have smaller and less abundant granules of different chemical nature; $\epsilon$, giant-cell (myeloplax) with three nuclei; $a, b, c$, and $d$, from the marrow of the fowl (Bizzozero), the red corpuscles of which are oval and nucleatcd, $c^{\prime} ; \epsilon$, from the marrow of the guinea-pig. (Schäfer.)

for "basic" anilin-dyes, such as dahlia. These cells are relatively large, and possess resieular and frequently polymorphic nuclei. Aside from these cells, which may be regarded as forming a part of the marrow, it contains red blood-corpuscles and leneoeytes, either formed within the marrow or brought to it by the cirenlating blood.

The functions of the various cells in bone-marrow have not been finally determined, but it is ecrtain that the erythroblasts, by their multiplication and tranformation, maintain the supply of red corpuseles circulating in the blood.

The arteries supplied to the marrow divide freely and open into small capillaries, which appear subsequently to dilate, and either to blend with the endothelial elements of the reticular tisne or to become pervions througl a scparation of the cells forming their wall:- In either cate the blood passes into the meshes of the reticular tisse, where it showly cireulates among the eonstituents of the marrow. It then passes into venons radicles devoid of valves, and is thence eonveyed from the bone. In some animals-e. $q$, birdsthe production of red corpuscles appears to be eonfined to the venons 
malicles (Fig. 111). The veins leaving the bones are abundantly supplied with valves.

FIfi, 111.

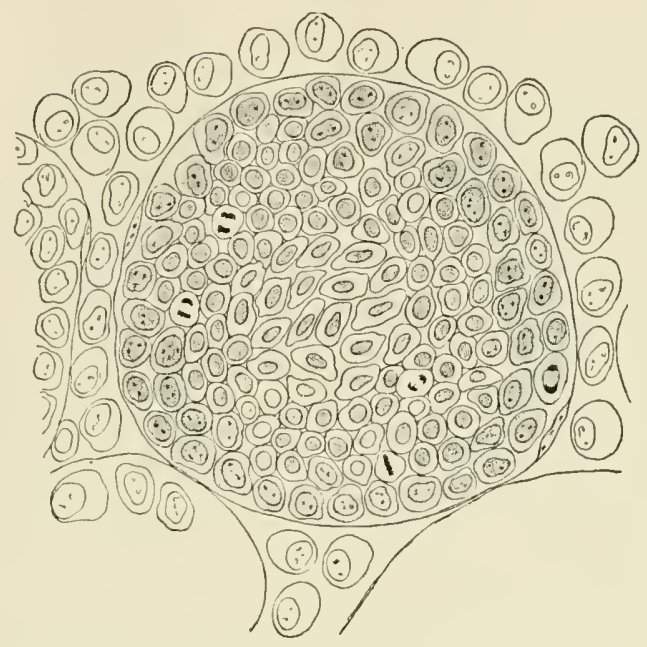

Section of small venous radicle in marrow of the fowl. (Bizzozero.) Just within the vascular wall is a zone of leucocytes, one of which contains a karyokinetic figure. Within this zone is a second zone of erythroblasts, four undergoing division, and in the centre of the lumen are a number of matured red blood-corpuscles (containing nuclei in the case of birds). The cytoplasm of the leucocytes contains no hemoglobin, while that of the erythroblasts does. In birds and, probably, in other classes of animals the marrow of the bones is one of the sites for the production of leucocytes as well as red corpuscles. The latter are not produced from the former, but only from the erythroblasts, which constitute a distinct rariety of cell.

Thronghout life the cancellated portions of the flat bones and of the bodies of the rertebre contain red marrow, but the shafts of the long bones are occupied by the yellow variety, which has lost its power of producing red blood-corpuscles and leucocytes, and has, therefore, become functionally passive. 


\section{CHAPTER IX.}

\section{THE BLOOD AND LYMPH.}

THE blood consists of a fluid, the plasma, in which three sorts of bodies are suspended: the red corpuseles, the lencocytes or white corpuseles, and the blood-plates.

The plasma is a solution in water of albuminous and other substances. Some of these are of nutritive value to the tissues of the body. Others have been reeeived from those tissues, and are on their way toward elimination from the body. Still other constitnents have passed into the blood from one part of the body, and are clestined to be of use to other parts.

In the smaller ressels, while on its course through the eireulatory system, portions of the plasma make their way through the vascular walls and form the fluid of the lymph. This passage appear's to be, in part, a simple filtration throngh the walls of the ressel, or the result of osmosis; in part, the result of a species of secretion

Fig. 112.
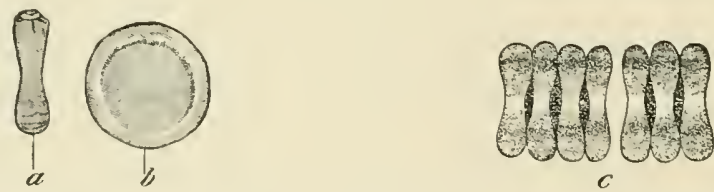

Red corpuseles from human blood. (Böhm and Davidoff.) a, optical seetion of a red bloodcorpuscle, seen from the edge; $b$, surface view. (The bounds of the central depression are made a little too distinct in this figure, as is evident from an inspection of $a$.) $c$, rouleau of red corpuseles. When undiluted blood has remained quiescent for a few moments the red corpuscles arrange themselves in such rows, probably because of the at Iraction which they, in eommon with other bodies suspended in a fluid having a nearly identical specific gravity, have for each other.

effected by the endothelial cells lining the bloodvessels, these cells promoting the eseape of reptain eonstitnents of the plasma and restraining or preventing that of other's. In the excreise of this seeretory function the endothelia in clifferent parts of the vaseular system appear to act differently, the eomposition of the fluid passing through the walls of the ressels not being exactly the same in all parts of the bocly. It is still a question, however, in what degree 
the endothelial cells are active in bringing about these difforences. Their chaneter is not snch as would he expected of cells carrying on active processes. Since the lymph is a solution separated from the blood by membranous capillary walls, and also coming into most intimate relations to the cells and intercellular sulstances of the tissues, the purely physical processes which might affect its eomposition are by no means simple. They may be grouped under three heads: filtration, osmosis, and diffusion. When fluids containing proteids are filtered under pressure, the filtrate contains a smaller pereentage of proteids than the original fluid. The element of filtration may, therefore, account for the smaller proteid content of the lymph than that of the blood-plasma. Osmosis is the flow of water through a membrane from a solution of lower molecular concentration to one of higher molecular concentration, and diffusion is the passage of dissolved solids from a solution of greater concentration with respect to a given substance to a solution which contains that substance in less concentration. By the term " molecular concentration" is meant the relative number of moleenles, free atoms, or radieles contained in a given bulk of liquid. The moleenlar concentration of the body fluids is usually measured by the depression of the freezing-point, as compared with that of pure water. For example, a solution of urea eontaining 60.12 grams in a litre and a solution of glucose in which 180.12 grams of the sugar are discolved in enough water to make 1 litre of solution both freeze at a temperature 1.85 degrees $\mathrm{C}$. below that of pure water-i.e., they depress the freezing-point 1.85 dagrees $C$. If these solutions were placed on opposite sides of a membrane, there would be no osmosis-i. e., no water would pass from one solution into the other; or if water did pass, equal quantities would pass in both directions, so that the interchange would cause neither concentration nor dilution of either solution. Both the urea and salt would diffuse through the membrane, so that eventually both solutions would have the same composition; each containing half of the urea and half of the sugar. Since the moleenlar weights of urea and dextrose are, respectively, 60.12 and 180.12 , these solutions are callerl equimolecular solutions, and are said to have the same molecular concentration and to exert the same osmotic pressure. The depression of the freezing-point is, then, a measure of moleeular concentration, and therefore of osmotic pressure, or of what may be considered as the attraction for water 
on the part of a solution when separated from pure water by a membranc. Now, althongh the solids in lymph are less than those in equal bulkis of the blood-plasma, the lymph freezes at a slightly lower point (about 0.02 degree C.) than the plasma, showing that it: molecular concentration is a trifle higher, and that there is a tendency for water to pass from the bloodversels into the lymphchamnels. This higher molecular concentration of the lymph is attributed to cell metabolism, during which larger molecules are alstracted from the lymph by the cells and smaller moleculesi. e., molecules of less molecular weight-are returned to it. The character of the lymph, then, will be affected by the metalulism of the cells with which it comes into relation. These effects and lifferences in the capillary blood-pressure may be sufficient to account for the differences in composition of lymph in various parts of the body, so that secretory activity on the part of the capillary endothelium is not necessarily a fuctor.

The red corpuscles are soft, clastic discs, with a concave impression in both surfaces (Fig. 112). They are slightly colored by a solution of hæmoglobin, and are so abundant that their presence gives the blood an intense red color; but when viewed singly under the mieroscope each corpusele has but a moderately pronounced reddish-yellow tinge. The hrmoglobin solution is either intimately associated with the substance composing the body of the corpuscles, called the "stroma," or it ocenpies the centre of the corpuscle and is surrounded by a pellicle of stroma.

Under normal conditions the red corpuscles, in man and most of the mammalia, are not eclls, for they possess no muclei, nor are they capable of spontaneous movement or multiplication. They are, rather, cell-products, being formed either within the cytoplasm of cells of mesoblastic origin, or by the division of cells derived from the mesoblast, and called erythroblasts, the lescendants of which become converted into red corpuseles through an atrophy and disappearance (probably expulsion) of the nuelei and a transformation of the cytoplasm into the stroma, which take place after the elaboration of the hemoglobin within the cell. The former, or intracellular, mode of production oceurs in the cmbyro, even before the complete development of the bloodvessels; the latter mode of production seems to be the only one oceurring in the adult, the chief location of the erythroblasts appearing to be in the red marrow of the 
bones, where they are situated either in the tissues of the marrow itself, whence their descendants, while still cellular, pass into the vessels, or in the large venous channels of the marrow, where the blood-current is sluggish and the erythroblasts remain close to the vasenlar walls. In some anemic conditions the erythroblasts apprir in the rirenlating blood, where they may he distinguished from the normal red corpuscles by the presence of their nuclei and, frequently, also by a difference in size (see Fig. 110, c).

In the reptilia and birds the red corpuscles are normally nucleated; but, though morphologically resembling cells, they are incapable of multiplication or spontaneons movement, and have umdergone such modifications that they are not cells in a physiological senve.

The functional value of the red corpuscles is dependent upon the hamoglobin they contain, which is said to constitute 90 per cent. of their solid matter. It is readily oxidized and reduced again, and serves to early the oxygen of the air, obtained during the passage of the blood through the pulmonary capillaries, to all parts of the body. 'The red corpuscles, therefore, subserve the respiratory function of the blood, as the plasma subserves its nutritive function.

The leucocytes, or white blood-corpuseles, are cellular elements closely resembling the amoba in their structure, which are present in the blood in much smaller number than the red corpuscles, the usual proportion heing abont one to six hundred. They vary somewhat in size and structure, either becanse of differences in their origin, or becanse they are in different stages of development. The majority of them are capable of amoboid movements; but while they are circulating in the more rapid currents of the blood the constant shocks they receive through contact with other corpuscles or with the vasenlar walls keep their cytoplasm in a contracted state and they maintain a globular form. If, however, through any chance they remain for some time in contact with the wall of a vessel, they are able to make their way between the endothelial cells and pass ont of the circulation into the surrounding tissues. Here they creep about, and for this reason have been called the migratory or wandering cells of the tissnes. They ultimately eithcr suffer degenerative changes and disappear, or find their way back into the circulation through the lymphatic channels. During these excursions they may incorporate stray 
particles in the tissues, and thus aet as scavengers. This activity has been called their phagoeytic function, and may play an important part in the removal of material that should be absorbed or of particles that would otherwise be injurious to the tissues; e. g., bacteria. (See statements regarding the nature of colostrum-corpuscles.)

The emigration of leneosytes from the bloodvessels is pronounced in many of the inflammatory processes, and their phagoeytic function may have a marked influence on the result.

The leneocytes are produced in the lymphadenoid tissues of the body, the lymphatic gland, thymus, spleen, and the more diffusely arranged tissues of like structure, but probably most abundantly in the red marrow of the bones.

A close study of the lencocytes has resulted in their subdivision into a number of groups according to their morphological differences

FIG. 113.

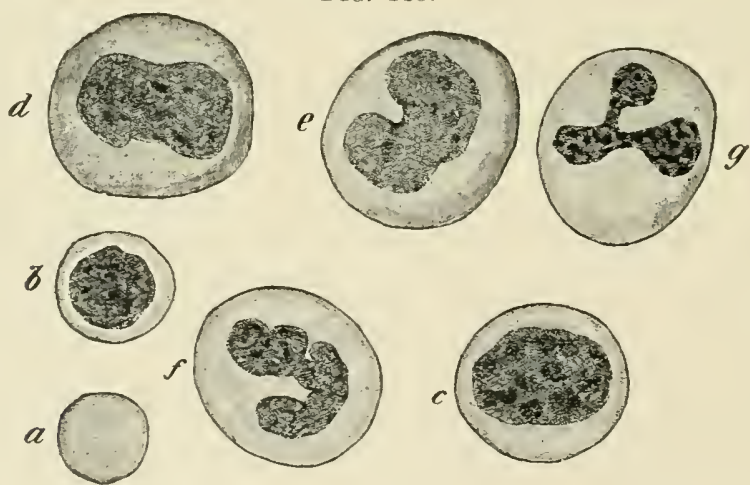

Leucocrtes from normal human blood. (Böhm and Davidoff.) a, red blood-corpuscle, introduced for comparison; $b$, small mononuelear leucocyte (lymphoeyte); $c$, large mononuclear leucocyte : $g$. polynuclear leucocyte. These differ in the character of the granules they contain (not represented in the figure). In normal blood those granules are neutrophilic in the vast majority of the polynucleated leucoeytes. Occasionally they are acidophilic, "esinophile leueocytes" ; sometimes basophilie, "mast-cells " or "plasma-cells." $d, e, f$, intermediate and probably transitional forms between the large mononnelear leucocytes $c$, and the polynueleated leucocytes, or leucocytes with polymorphic nuclei, $g$.

or to peculiarities in their behavior toward coloring-matters. The best defined of these groups are:

1. The polynuclear neutrophilic leucocytes, in which the nucleus has a very irregular form, often presenting the appearance of two or more nuclei, and the eytoplasm contains granules that have an 
affinity for neutral anilin-dyes (Fig. 118, $f$ and g). This variety constitutes abont 72 per cent. of the total number of lencocytes, and is probably produced ehiefly in the red marrow of the bones. They possess the power of executing amceboil movements and ineorporating foreign particles.

2. The lymphocytes, with a single round nucleus and a little clear eytoplasm around it. These lencocytes are of about the same size as the red blood-corpuseles (Fig. 11:3, b). They are derived from the lympharlenoid tissue in the lymph-nodes and other situations, and appear to be capable of only feeble amceboid movement. They constitute about 23 per cent. of the total number of lencocytes in normal blood.

3. The large mononuclear leucocytes, which are larger than the red corpuscles and have oval muclei surrounded by clear eytoplasm (Fig. 113, c). This variety has also received the name "myelocyte," on the probably correet assumption that they are derived from the red marrow of the bones. They are capable of passing through transitional forms until they aequire the eharacters of the polynuclear nentrophilic leneoeytes deseribed above. The large mononuclear leucocytes, together with the transitional forms, make up about 3 per cent. of the normal number of leucocytes.

4. The eosinophilic leucocytes (Fig. 110, d), also larger than the red corpuseles, with irregular, polymorphic nuclei, and a cytoplasm containing relatively large granules which have an affinity for acid dyes; $e . g$, eosin. These are frequently seen in unusual numbers around inflammatory foei or in tissues undergoing involution; e.g., in the connective tissue of the hreast when lactation is suspended. Their significance is not understond, but they appear to be derived from the red bone-marrow. They constitute from 1 to 2 per cent. of the total number of leneocytes.

5. Basophilic leucocytes, occasionally met with, which are characterized by the presence of granules in the cytoplasm having a special affinity for basie anilin-colors. These cells have also received the names "mast-cells" and plasma-cells, but the latter term is indefinite, having been applied to a number of cells of different nature.

The blood-plates are colorless round or oval discs, about onefourth the diameter of the red corpuscles. Their function has not been definitely determined, but it is thought that they may play a rôle 
in the production of fibrin, perhaps by the liberation of fibrinferment.

Minute globules of fat are nccasionally present in the blond, especially during digestion.

The lymph, like the blood, consists of a fluid portion, the plasma, and corpuseles held in suspension.

The plasma, as would be anticipated from its origin, is very similar in composition to that of the blood.

The corpuscles are, for the most part, identical with the small leucocytes (lymphocytes) of the blood, which derives its supply of those cells from the lymph flowing into it.

The chyle is the lymph found in the lacteal lymphatics during digestion. When absorption of the products of digestion is in progress this lymph contains a great number of globules of fat, some so minute as to be barely visible under the microncope. In the intervals between absorption this lymph does not differ from that found in the other lymphaties of the body.

Fibrin may present the appearance of a delicate network of extremcly fine fibres, somewhat resembling a cobwol, or these fibrils may be aggregated into larger threads varionsly interwoven, or they may be still further condensed to form masses of a hyaline character. The fibres may undergo a disintegration into granules, when their fibrinous nature is not readily revealed. Fibrin is not found in the body under normal conditions, but separates from the blood if the circulation be arrested for any considerable length of time. It appears to be the result of the interaction of four substances: fibrinogen, fibrinoplastin, fibrin-ferment, and salts of lime. The latter are always present in the tissues; fibrinogen exists in the plasma of the blood and lymph, and is, therefore, very widely distributed. The fibrinoplastin is believed to be derived from the bodies of eells that have undergone some destructive change; and the ferment may be derived from the same souree. There four substances are present when the flow of blood through the vessels has been seriously checked for a considerable period; fibrin is then formed, causing a coagulation of the blood. Such a clot, within a ressel during life, is called a "thrombus." Coagulation takes place more rapidly if there be a destruction of tissue; e.g., a break in the wall of the resicel. It may also be occasioned by a ronghness on the internal surface of the ressel, if the flow of blood over that obstruction is serion-ly retarder. In such a case the 
fibrin-forming elements may be liberated from the bodies of leucoeytes that find lodgement behind the obstruetion and suffer injury, or they may be derived from blood-plates that have been arrested and undergone similar ehanges. In a like manner, fibrin may be formed in the lymphatic vessels or the interstices of the tissues.'

1 An explanation of fibrin-formation, offered by Lilienfeld, would serve to elucidate many cases of coagulation under morbid circumstances. According to this observer, fibrin is formed by the union of "thrombosin" with calcium, and is, therefore, a calcium-thrombosin compound. The thrombosin is produced from fibrinogen by the action of nuclein, which in turn is formed from the nucleohiston contained in the nuclei of cells. Coagulation, then, would be the result of the following process: the nucleohiston in the nuclei, during "karyolysis" or disintegration of the nucleus, is decomposed into "histon" and nuclein. The latter, acting on fibrinogen, produces thrombosin, which unites with calcium to produce fibrin. 


\section{CHAPTER $\mathrm{X}$.}

\section{THE DIGESTIVE ORGANS.}

THE digestive tract consists of six hollow, and for the most part, tubular organs, which snceessively open into each other and extend from the pharynx to the anus. The food, after mastication and admixture with saliva in the month, passes throngh (1) the resophagus into (2) the stomach. Here it undergoes digestive changes under the influence of the gastric secretions. Thence it passes into (3) the duodenum, where the secretions of the liver and pancreas and other glands are mixed with it and still further fit it for absorption. From the duodenum it enters (4) the small intestine, the walls of which take up the available produets of digestion, and thence passes into (5) the colon. In the latter the flnid portions are gradually absorbed and the relatively dry residue, the freces, passes ont of the borly throngh (6) the reetum and the anal orifice.

The walls of the digestive organs have a general similarity thronghout the whole of the digestive tract. They consist of four coats: 1 , an internal mueous membrane; 2 , a submucous eoat ; 3 , a muscular coat ; and, 4, either a serons or a fibrons external eoat. These coats are, respectively, continnous with each other throughont the whole tract. The internal coat, or mucons membrane, varies in both structure and function in the different organs, and will, therefore, require closer study than the other coats. The latter have nearly the same strmeture in all the organs. The submucous coat is made up of areolar fibrous tissue, which permits some freedom of motion between the mucous and muscular coats, and contains the larger bloodvescels and lymphatics that supply all the eoats. The muscular coat consists, in general, of two layers of smooth muscular tissue : an internal circular layer and an external longitudinal layer. Its function is to prodnce those vermienlar or peristaltic movements which mix and gradually propel the food along the digestive tract. The external coat is smooth and serous over those portions of the tract which require the greatest freedom of motion. It is nowhere complete, but, where present, is really a portion of the 
peritonemm which partially anvelops the organs that are contained in the abdominal avity. Where this serous covering is wanting the external coat consists of aroular fibrous tissue, which serves to commect the organs of the ligestive tract with neighboring structures, and thus becomes contimous with the areolar-tissue system pervaling the whole body. It supports the vessels and nerves which make their way through it to the different organs.

In addition to the organs above enumerated, it is appropriate to consider here the structure of the tongue, pharynx, salivary glands, and pancreas.

1. The tongue consists chiefly of voluntary muscles, the fibres of which are grouped in bundles rumning in various directions through the substance of the organ. Between the individual striated muscle-fibres, and also between the bundles into which they are collected, there is a variable amount of areolar fibrous tissue containing fat, nerves, and bloodvessels (Fig. 67). This areolar tissue

FIG. 114.

Fig. 115.
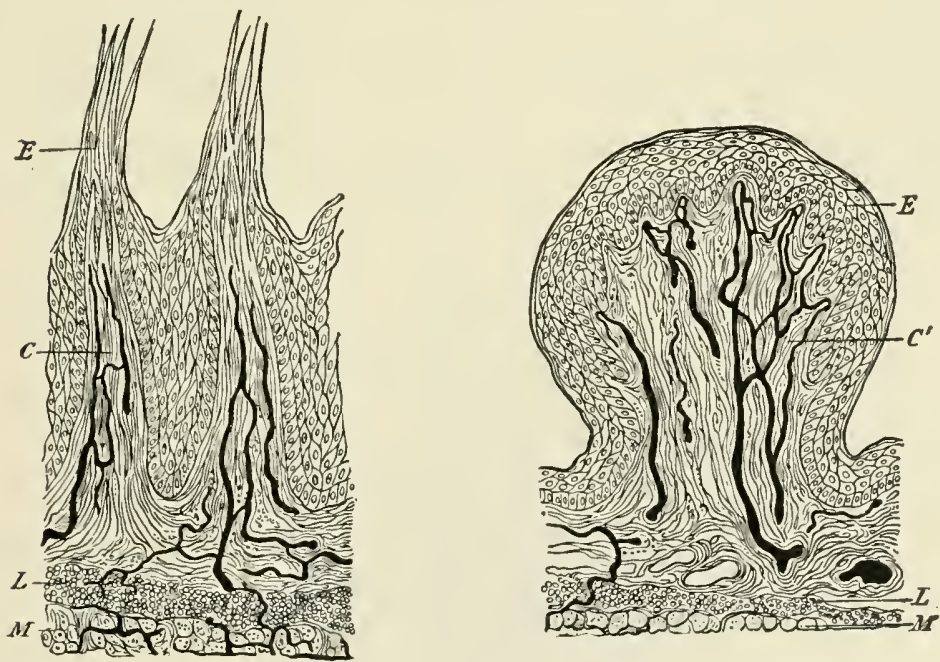

Sections of papillæ of tongue.

Fig. 114.-Filiform papillæ; human. Heitzmann.)

Fig. 115.-Fungiform papille; human. (Heitzmann.)

$E$, stratificd epithelium; $C$, injected capillaries within the fibrous tissue of the papillæ; $L$, lymphadenoid tissue in lower portion of mucous membrane; $M$, muscular tissue of the tongue.

is more abundant near the surface of the tongue, and is covered with a layer of stratified epithelium, thicker at the sides and on the dorsum of the tongue than on its under surface, where it becomes 
continuons with the stratified epithelium covering the gums and lining the buecal cavity.

FIG. 116.

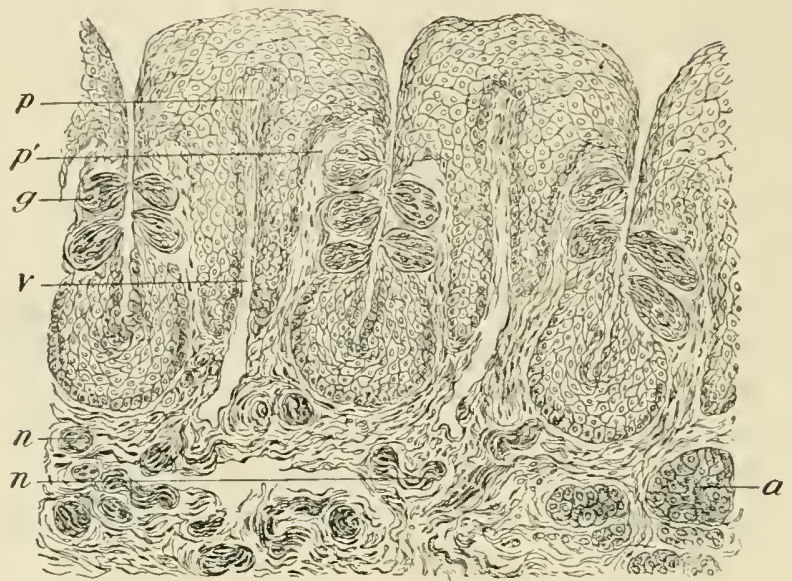

Two cireumvallate papille; rabbit. (Ranvier.) $p, p^{\prime}$, fibrous tissue extending into the papilla; $p^{\prime}$, that containing the nerves passing to the taste-buds; $g$, taste-buds; $\nu$, small vein; $n, n$, nerves; $a$, acini of a serous gland.

The upper surface and the edges of the tongue are covered with papilla, some of which are pointed (filiform papillæ), others rounded

Fiti. 117.

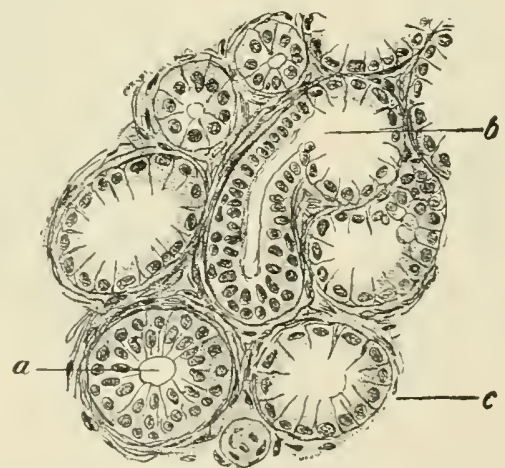

Portion of a section of a mucous glant in the luman tongue. (Benda and Guenther's Atlas.) $a$, duct; $b$, acinus opening into a duct-radicle; $c$, acinus lined with mucigenous cells, sim. ilar to $b$. Between and below a and $c$, eross-section of a small artery, recognizable by the elongated nuclei of its muscrular coat.

(fungiform papilla), and still others surrounded by a suleus (circumvallate papilla) (Figs. 114-116). Within the epithelium lining 
this suleus are peculiar groups of cells, called taste-buds, which will he described in a subsequent chapter. At the junction of the midulle and posterior thirds of the upper surface of the tongue there are several of these cireumvallate papilla which are of unusual size.

Within the subepithelial areolar tissue, and often extending for some distance between the muscles, there are, here and there, small racemose glands, which secrete a serous or mueons fhid (Figs. 116, a and 117). They are most abmudant on the back and sides of the porterior part of the tongue, and their duets frequently open into the sulei of the circmuallate papilla. Within the subepithelial areolar tissne suall collections of lymphadenoit tissuc (lymph-follicles) are also of not infrequent occurrence. The papilla covering these are low and inconspicuous, so that the surface of the tongue appears umsually smooth at those points.

2. The salivary glands belong to the racemose variety of seereting glands. The secretions which they furnish are of two kinds: 1 , a thin, serous fluid, containing albuminoid materiak, among which are the specifie ferments elaborated by the gland; and, 2, a viseid thuid containing mucin. These two secretions are furnished by acini lined with different rarieties of epithelium. The parotid gland secretes only the serous fluid, and is composed of serous alveoli. The sublingual gland secretes only the mucous fluid; but the submaxillary grland secretes both, and, therefore, contains both serous- and mucous-secreting cells.

The cells which line the mucons acini lave clear bodies, as the result of a storage of transparent globules of mucin or mucigen within the cytoplasm. Where these globules are abundant the nuclei of the cells are crowded towarl the attached ends of the cells. When the mucin is discharged from the cells they become smaller, less clear, and more gramular in appearance.

At the periphery of the acini, and specially well marked at or near their blind extremities, are, here and there, crescentic, granular epithelial cells, which may reach the lumen of the acinus or be crowded hack by the enlarged cells adjoining them. These cells form the "ereseents of Giannzzi." In the submaxillary gland, at least, many of these creseents secrete the serous or albuminoid fluid mentioned above. This secretion resches the lumen of the gland through minute intracellular channels (Fig. 118).

The serous alveoli of the salivary glands are lined with cells that, 
at certain stages of their activity, are so crowded with granules that the nuclei are obseured. These granules are the acemmulated material from which the secretion is formed, and when the gland has been functionally active for some time they diminish in number,

FIG. 118.

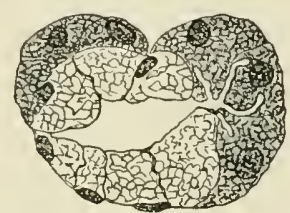

Section of an acinus of the human subnaxillary gland. (Krause.) The lumen is surrounded by mucous cells, containing globules of mucigen. Two groups of Gianuzzi's crescents are represented, with the intracellular channels conveying the serous secretion to the lumen.

and the muclei then eome into view. At the same time the cells become smaller, and the lumen within the acinus, which at first was barely distinguishable, beeomes more olvvions.

The epithelium lining the acini of all the salivary glands rests

FIG. 119.

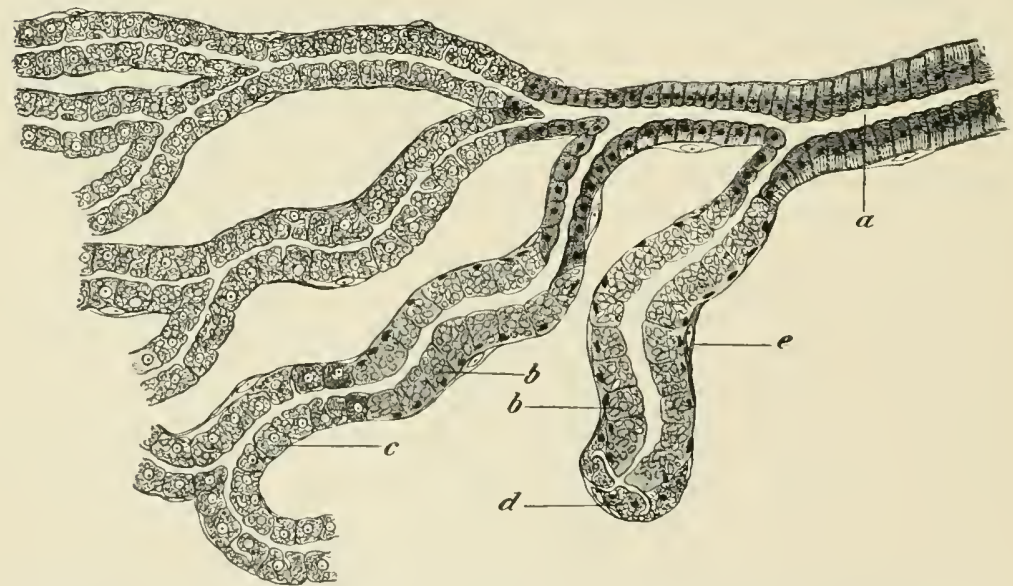

Diagrammatic representation of a portion of a human submaxillary gland. (Krause.) a, duct, lined with columnar cells, striated at their bases and passing into a more cubical epitheliun without such striation; $b$, mucous cells; $c$, serous cells; $d$, creseent; $e$, basement. membrane. In this figure the convoluted course of the ducts and tubular acini has been ignored, and they have been represented as though lying in a single plane.

npon a modified connective tissue, called the "basement-membrane," which consists of flattened cells arranged to form a broad, membranous reticulum, the meshes of which are filled with cement. Ontside of this basement-membrane there is a small amount of 
vascular areolar tissue, and broader bands of that tissue divide the whole gland into small lobes and these again into still smaller lobules (Fig. 25).

The duets of the salivary glands are lined with columnar or pyramidal epithelial cells, the attached ends of which often show a stria-

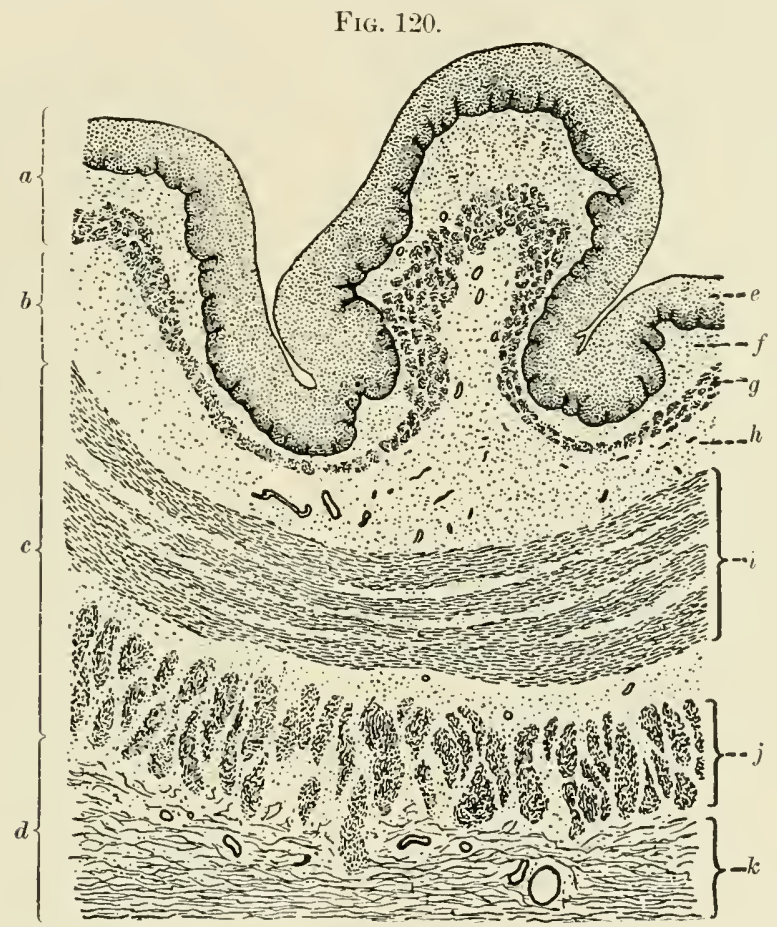

Part of a cross-section of the asophagus of a dog. (Böhm and Davidoff.) $a$, mucous membrane; $b$, submucous coat : $c$, muscular coat; $d$, fibrous coat; $e$, stratified epithelium; $f$, subepithelial areolar tissue (sometimes called the "tunica propria" of the mucous membrane); $g$, muscularis mucosæ; $h$, areolar tissue of the submucosa, containing the chief branches of the arterial and venous vessels; $i$, internal, encircling layer of the muscular coat. It is the contraction of this coat that has caused a longitudinal wrinkling of the mucous membrane. One of those folds is completely and two are partially shown. $j$, exterual, longitudinal layer of the muscular coat; $k$, areolar tissue forming the external coat and connecting the cespphagus with neighboring structures. A few large vessels entering the cesophagus are represented in this coat.

tion perpendicular to the surfice of the basement-membrane (Fig. 119).

The nerves ramify in the interlobular areolar tissue and send delicate, non-medullated fibres through the basement-membrane to be distributed upon and between the epithelial cells. Oceasionally small ganglia are scen upon the larger nerves. 
3. The Esophagus (Fig. 120).-The mucons membrane of the resophagus is composed of three layer's. The innermost layer is made up of stratified epithelium. Beneath this is a layer of filorous tiscue, with small papillae extending into the deeper portions of the epithelium (see Fig. 38). Outside of this is a layer of longitudinal smooth muscular tissue, the "muscularis mucose." This is but imperfectly represented at the upper part of the resophagus, but at the lower end forms a continuous layer separating the "tunica propria" (Fig. 120, $f$ ) of the mucous membrane from the submucons coat, and becoming continuons with a similar laver of smooth muscular tissue in the mucous membrane of the stomach and intestine. Occasionally small, imperfectly defined lymph-follieles are met with in the mucous membrane.

The submucous coat of loose areolar tiscue contains small racemose glands sparsely distributed through it, the ducts of which penetrate the mucous membrane and open upon the internal surface of the asophagus.

The muscular eoat consists of an internal ('ircular and an external longitudinal layer, which at the upper end of the resophagus are componed of striated muscle. This is gradually replaced by smooth muscular tissue further down the esophagns, and at its lower end only the latter tissue is fomnd.

The external coat of the cesophagns is represented by a variable amomt of areolar tissue which hoosely comnects it with the surrounding structures.

4. The Stomach.-Nearly the whole thicknes of the mucous membrane of the stomach is made up of straight tubular glands (gastric tubules), which lie perpentienlar to the surface, and are separated from each other by only a small amount of a delicate, highly vasenlar areolar tissme. This is a little denser and more abundant below the deep ends of the glands, where it separates them from the muscularis mucose forming the decpest layer of the mucous membrane.

The months of the gastrie tubules open into shallow, polygonal depresioms or erypts on the surface of the mucous membrane, several glands opening into each depression. These depressions give the internal surfice of the stomach a retieulatrappearance when viewed with a low power. They, and the ridges which separate them, are covered with a rather tall columnar "pithelium. The glands which open into them are of two kinds: the "pyloric" 
FIG. 12:.

FIG, 121.

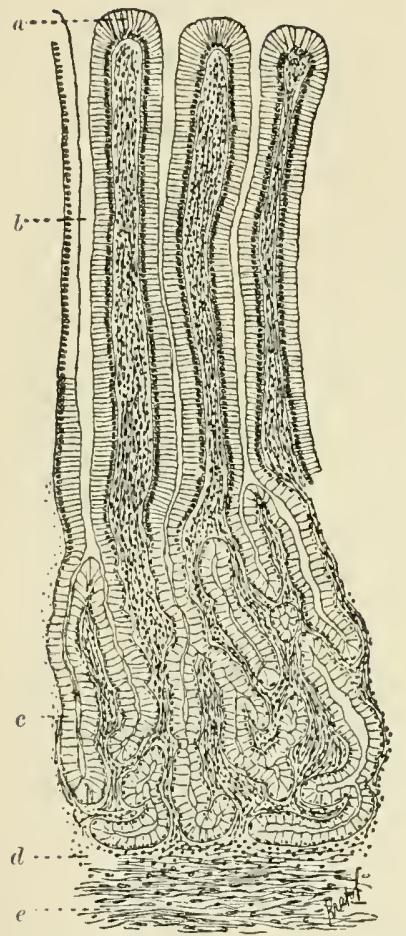

Fig. 121.-Vertical section through mucous membrane of pyloric end of stomach; human. (Böhm and Davidoff.) $a$, columnar epithelium covering surface of mucous membrane; $b$, erypt lined with somewhat lower columnar epithelium; $r$, gastric tubules; $d$, tunica propria, somewhat lymphoir in character; $e$, museularis mucose, of smorth muscular tissue.

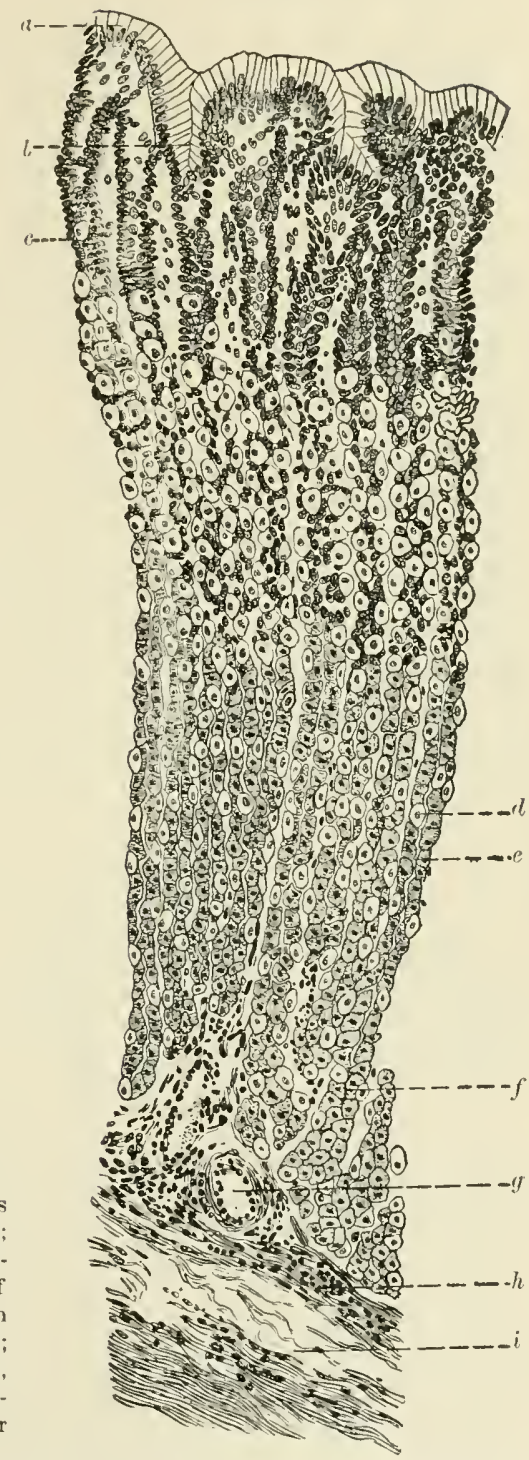

Fig. 122.-Nearly vertical section of the mucous membrane near the eardiac end of the stomach; rabbit: $a$, columnar epithelium covering the surface of the mueous membrane: $b$, that lining a crypt; $c$, duct; $d$, parietal cell extending to the lumen of the gland: $e$, lumen, readily traced for only a short distance; $f$, central or chief cells; $g$, small artery, to the left and above it, a small vein; $h$, muscularis mucose, consisting of three thin layers of smonth museular tissue, the middle layer in transverse, the others in longitudinal section; $i$, portion of submueosa. The specimen was taken from an animal some time after the ingestion of food, and the chief cells are, in consequence, relatively small in comparison with the size of the parietal cells. 
variety, so-ealled because more ahmondant at the pyloric end of the stomach, and the "cardiac" variety, which preponderate near the carliac end.

The pyloric glands (Fig. 121) have the simpler structure. They possess a comparatively deep and open month, lined with columnar epithelial cells similar to and continuons with those lining the depressions already mentioned, and, like them, mucigenous. Into these mouths one or more straight tubular glands, lined with low, granular columnar cells, discharge their sceretion.

The cardiac glands (Fig. 122) have shallower months than the pyloric glands, and the tubes that open into them eontain two sorts of epithelial cells: 1 , the "chicf" or central cells, which line and nearly fill the whole tubule, leaving only a very small and somewhat tortnous lumen in the centre; and, 2 , the parietal cells, lying at intervals between the central cells and the surrounding connective tissue, but sometimes projecting between two central cells nearly or quite to the lumen of the gland. Very fine channels rum from that lumen to and around these parietal cells, which are believed to produce the free acid of the gastric juice (Figs. 123-125).

FIG. 123.

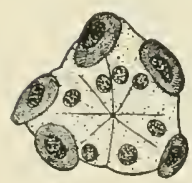

FIG. 124.

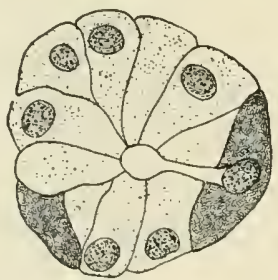

FIG. 125.

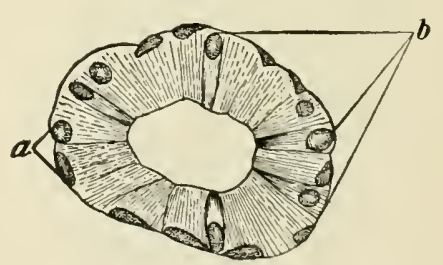

Cross-sections of gastric glands; dog. (Hamburger.)

Figs 123 and 124.-From the eardiac end of the stomach, showing the chief or central celts and the parietal cells. 123, from a dog killed during the second hour of digestion. The central cells are relatively large, and the lumen is reduced to a mere line, appearing as a dot in the centre of the cross-section. 124, from a dog killed during the seventh hour of digestion. The parietal cells are relatively large, and the lumen more distinet than in $1: 3$, owing to loss of material on the part of the central cells and a gain on the part of the parietal cells. One of the latter is in communieation with the lumen through a small channel between the central cells.

Fig. 125.-From the pyloric enr of the stomach during the fifth hour of digestion. The cells $b$ have parted with their secretion and are compressed by the cells $a$, which still retain the materials stored for secretion. The lumen of the gland is much larger than that of the glands at the cardiac end of the stomach.

Besides the secreting glands, the mueons membrane of the stomach sometimes contains small lymph-follicles. Its blood- and lymph-supplies are aluundant, and nerves are distributed to its various tisste-elements. 
The deepest layer of the mucous membrane is the muscularis mucose, made up of two or three strata of smooth muscular tissue in which the fibres run in different direetions.

The submucous coat of the stomach consists of loose areolar tissue, which allows considerable freedom of motion between the mucous membrane and the muscular coat. When, therefore, the organ is empty the contraction of the muscular coat throws the mucous membrane into coarse folds (rugie). The large arteries, veins, and lymphaties course in this submucous tissue, and thence send branches into both the mucous and muscular coats. The nerves also form a ganglionated plexus in this coat.

The muscular coat consists of an external longitudiual layer, inside of which is another layer encircling the organ. The external layer is continuons with the outer muscular layer of the oesophagus. The internal musenlar layer of the latter organ is continued into the wall of the stomach as a seattered set of oblique fibres lying internal to the encircling fibres already mentioned. The muscular coat of the stomach may, therefore, be considered as composed of three layers, the innermost of which is incomplete. At the pylorus the encireling museular layer is thickened.

Aside from the fibrons tissue that more or less completely separates its layers, the muscular coat contains ganglionated nerveplexuses.

The external surface of the stomach is covered with a serous investment of peritoneum, except along the curvatures, where the peritoneum is reflected from the organ, permitting the passage of its ressels and nerves.

5. The Duodenum.-The structures characteristic of the small intestine first make their appearance in the duodenum. We shall first consider those features which are found thronghout the small intestine, and then deseribe those which are peculiar to the duodenum (Fig. 126).

The mucons membrane presents thin, transverse folds, the valvulæ conniventes, which are not obliterated when the intestinal wall is stretched. They are made up of a thin layer of areolar tissue, extending from the submueous coat of the intestine, which is covered on both surfaces with mueous membrane. This arrangement serves greatly to increase the surface of mueous membrane coming in contact with the contents of the intestine, a provision facilitating absorption of the products of digestion. 
The valvule comniventes begin a short distance below the pylorus, and are very numerous and prominent in the duodenum, but become progresively less frequent and pronomeed in the lower portions of the small intestine.

The absorbent surface of the small intestine is still further in-

Fig. 126.

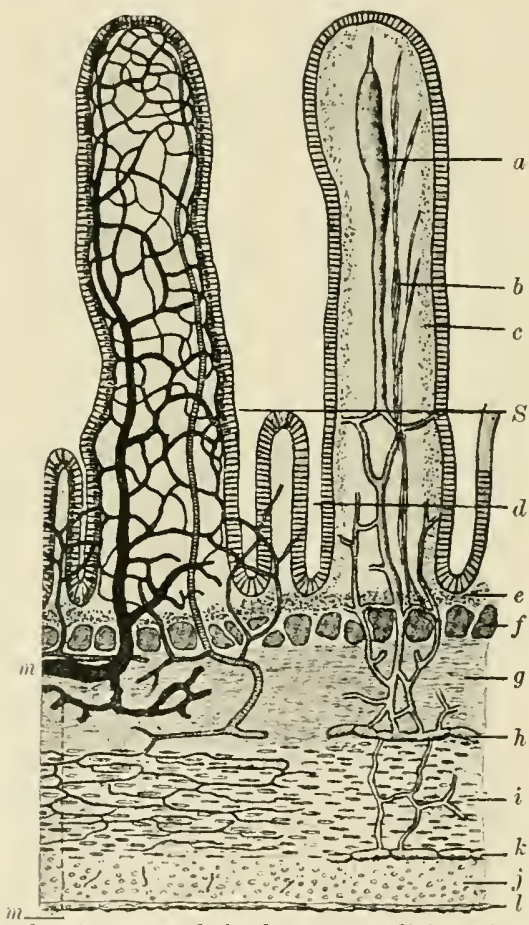

Diagram representing the strueture of the human small intestine. (Böhm, Daridoff, ancl Mall, slightly modified.) Two villi are represented. In the one on the left the bloodressels are shown: in the one on the right, the lymphatics. The line sindieates the surface of the mueous membrane between the villi. $a$, central lacteal ressel; $b, \operatorname{smuth}$ muscular fibres extending into the villus from the museularis mueosæ: $c$, lymphadenoid tissme beneath the epithelial covering of the villus; $d$, erypt of lieberkühn; $\epsilon$, tunica propria of lymphadenoid tissue, and entinuons with that of the villus; $f$, museularis mucos:e, forming the deepest portion of the mueous membrane; $g$, submueosa containing the larger bloodvessels and the lymphatic glexus $h$; $i$, encireling layer of the muscular coat $;$, longitudinal layer; $k$, lymphatie plexus within the musenlar coat $l$, serous coat; $m$, vein. The crypts are lined, and the villi covered, with columnar epithelium.

creased by the presence of innumerable minute, finger-like projections from the surface of the mucous membrane, the villi. These are just discemible by the unaided eye, and give the internal surface of the intestine a velvety appearance. 
Between the attached ends of the villi, and opening upon the surface of the mueous membrane, are tubular depressions extending nearly to the museularis mueose. These are the " erypts of Lieberkühn," and have the appearance of simple tubular glands; but it is doubtfil if they elaborate any peenliar secretion. These erypts are present, not only in the whole extent of the small intestine, but also throughout that of the colon.

The crypts of Lieberkïhn are lined with colummar epithelium, which also covers the surface of the mucous membrane and the villi springing from it. The cells composing this epithelium multiply in the erypts, and, as they mature, are gradually moved toward their orifies, whence they replace those that have been destroyed upon the surfaces of the villi. The cells possess a granular eytoplasm, which becomes infiltrated with fat during digestion; an oval, vesicular nucleus; and a delicate cell-membrane. The free ends of the cells are formed by a well-marked cuticle, which may be either homogeneons in appearance, or present very fine vertical striations (Fig. 37). Many of the cells are mucigenous and contain glohnles of mucus near their free ends, or appear as goblet-cells after the discharge of that secretion. These cells are more abundant on the villi, where they are older, than in the erypts lined with less mature cells.

The epithelium rests upon a basement-membrane, which contains muclei, and is therefore composed, in part at least, of cells. Beneath this basement-membrane is a layer of reticular and areolar tissues, containing a variable number of lymphoid cells and numerous capillary bloodvessels. The rest of the mueous membrane, down to the musenlaris mucose, and the axes of the villi are oceupied by areolar fibrous tissue.

The thin muscularis mucose, which forms the deepest layer of the mucous membrane, is made up of two layers of smooth muscular tissue : an internal layer, in which the fibres run transversely to the axis of the intestine, and an external longitudiual layer. From the upper surface of this muscular layer of the mueous membrane muscular fibres extend into the villi, in the areolar tissue in their axes, and serve to shorten the villi by their contraction, so that the villi are moved about in the intestinal eontents during the process of absorption. In the centre of each villus is a capillary lymphatic vessel arising in a blind extremity near the apex of the villus. These lymphaties open into a lymphatic plexus situated between the muscularis mucose and the ends of the erypts of Lieberkïhn, and thence discharge their contents into the lrmpluaties in the sub- 
mucosa. The muscular fibres in the villi probably aid in the propulsion of the chyle in these lymphatics (Fig. 127).

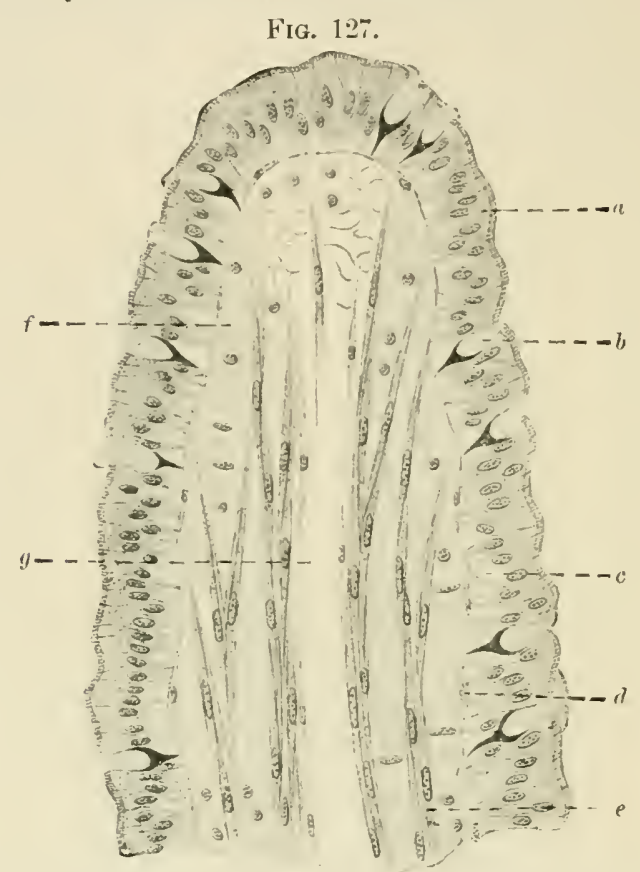

Axial section of villus of the dng. (Kultschitzky.) $a$, epithelial covering with cuticle: $b$, goblet-cell; $c$, space between tapering ends of the epithelial cells; $d$, cell of the basement-membrane; $e$, smooth muscular fibres; $f$, reticulum of the tunica propria (tlie lymphoid cells have been, for the most part, removed); $g$, lumen of the central lymphatic The bloodressels are not represented.

The submucous cont of the intestine is composed of areolar fibrons tissue. Outside of this coat is the muscular coat, divisible into two layers, which is covered throughout the whole circumference of the intestine, except at the line of mesenteric attachment, with a scrous investment of the peritoneum.

In the duodenum the submucons coat eontains compound tubular glands, the glands of Brumer, the duets from which penetrate the muscularis mucose and open upon the surface of the mucous membrane, between the erypts of Lieberkiuhn. Here and there, in the duodenum, are little collections of lymphadenoid tissile, ocenpring an enlarged villus and often extrnding throngh the muscularis mucose into the submurous areolar tissue (Fig. 128). These lymph-follicles may be regatuled as the result of an increase in the amount of retienlar tissue of the villus, which hats replaced the other structures usually present. In the lower portions of the 
small intestine there are collections of these solitary follicles, which have received the name "Peyer's pateher."

6. The small intestine below the duorlenum resembles the latter

Fig. 128.

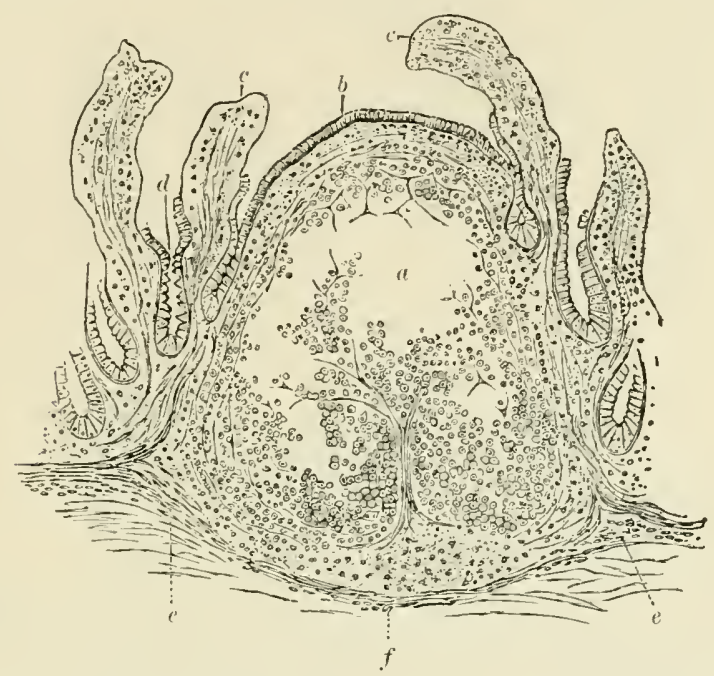

Section of solitary follicle from the ileum. (Cadiat.) $a$, space left by the disintegration of the central, delicate lymphadenoid tissue of the follicle during the preparation of the section; $b$, columnar epithelium of intestinal surface; $c, c$, villi, partially denuded of epithelium : $d$, erypt; $e, f$, muscularis muense; abore $f$, the point where the vessels enter the follicle. The Peyer's patches are collections of such solitary follicles, placed side by side and destitute of villi at their upper surfaces.

in structure, with a few modifications, which become progressively more marked as the distunce from the stomach increases.

The grlands of Brumer are most abundant near the upper part of the duodenum, more sparsely distributed further down, and usually disappear entirely before the beginning of the jejumum.

The valvulae conniventes, which are most highly developed a little below the entrance of the gall and pancreatic ducts, also become lower and less frequent along the eourse of the intestine, and finally disappear about the middle of the ileum.

The crypts of Lieberkïhn are deepest in the upper part of the intestinal tract, but persist in shallower form throughout its whole extent, as well as along the whole length of the colon.

The Peyer's patches are most abundant in the lower part of the ileum, where they lie in the intestinal wall opposite the line of mesenteric attachment, and form oval areas with their long axes parallel to the axis of the intestine.

7. The Colon.-The mueous membrane of the colon is destitute 
of villi, but contains erypts of Lieberkiihn elosecly arranged side hy side and lined with colmunar epithelinn rich in mueigenons cells. The muscularis mucose is similar to that of the small intestine, and gives off oceasional fibres that penctrate between the erypt:-

The submucons coat resembles that of the small intestine, and, in eommon with the mucons membrane, contains solitary lymph-follicles, most abundantly in the execum and rermiform appendix.

The muscular eat has its outer or longitudinal layer most highly developed in three bands, which are situated about equiclistantly around the eireumference of the bowel and oceasion a pouching of the intervening wall.

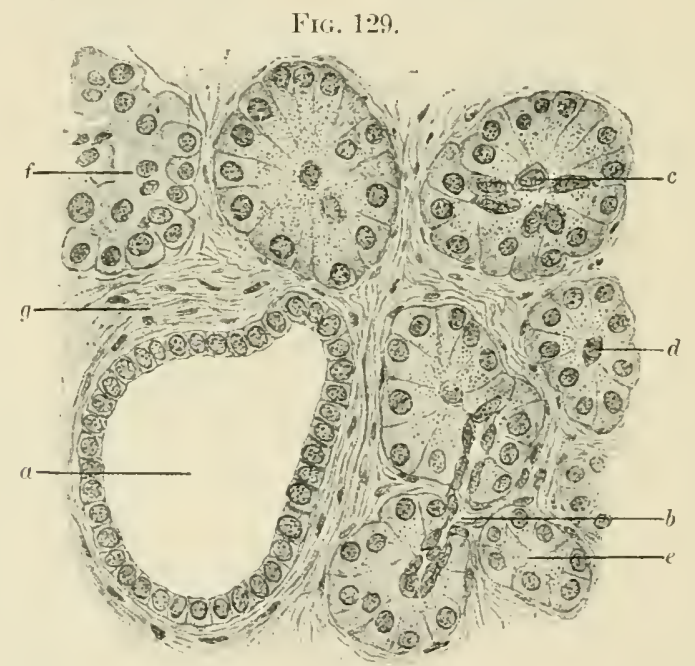

Section of luman pancreas. (Böhm aud Davidoff.) $a$, larger duet; $b$, becrinning of duct; $c, d$, acini with cells belonging to the corresponding duct-radicles in their centers; $\ell$, acinus, eut just beyond the lumen; $f$, interalveolar cell-group (?); $g$, fibrous connective tissue, forming the interstitial tissue of the organ.

The serons coat is similar to that of the small intestine, hut is oceasionally extended oxer small pendulous projections of the substrous fibrous tissue, which contain adipose tis-sue, appendiceepiploice.

8. The rectum resembles the colon in its structure, exeept that the three muscular bands present in the latter are wanting. The mucous membrane ats it paseses into the anal canal loses its tubular glands, and subsequently becomes covered, not with columnar, but with stratified epithelium, continuous with the epidermi- of the skin around the annis.

9. The pancreas (Fig. 129) has a structure similar to that of the 
silivary glands, but its lobules are separated and held in place by a rather more considerable anomt of loose areolar tissue, in which there are oecasional groups of eells of uneertinin nature, but certainly distinet from those lining the glandular acini. They are called the "interalveolar cell-islets," and may, perhaps, be of the nature of ductless glands (\%. ¿.). These structures, also known as the islands of Langerhans, have no seeretory duets, and are composed of eells of epithelial nature which lave the same origin as the ordinary secreting cells of the pancreas. They are not grouperl so as to form acini, but are arranged in ana-tomosing columns, like the cells of the liver, with an abundant eapillary network situated in the spaces between these columns of cells. The rells are devoid of zymogen granules, but are of two kinds: 1 , smaller eells with faintly staining eytoplasm and a vesienlar nuclens in which the chromatin

FIG. 130.
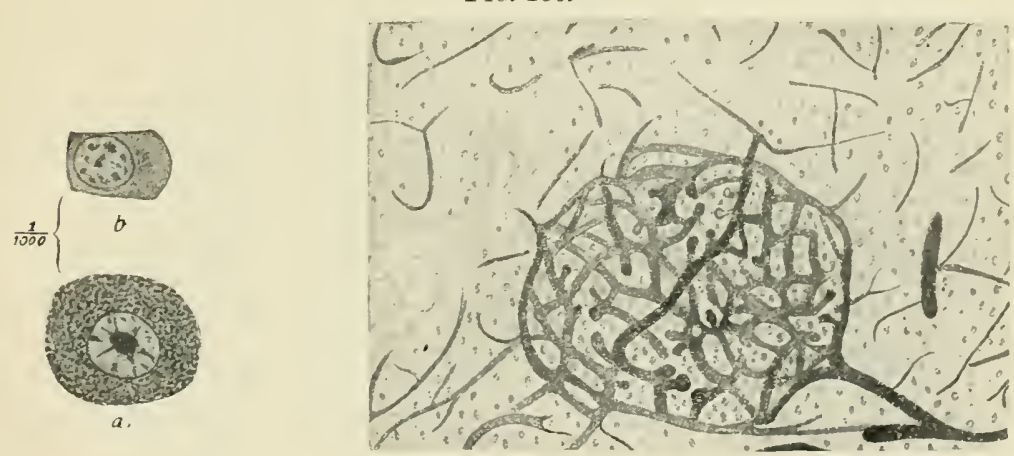

$\frac{1}{175}$

Island of Langerhans, guinea-pig. (Schulze.) $a$ and $b$, isolated cells; $c$, injection of bloodvessels showing the abundant, capillary network within the islind.

is more or less massed into granules; and, 2, litreer cells with a crtoplasm that stain. more deeply (Firg. 130). The inlands of Langerhans have of late received much attention as posibly being the struetures elaborating an internal seeretion of importance in the general carbohydrate metabolism of the body.

As the panereas exereises its secretory function the granules within its cells move toward the lumina of the arini and suces-ively disappear, the attached end of the cells beeming elearer and the whole cell diminishing somewhat in size during the process.

The nerves of the stomach and intestinal tract form two ganglionated plexuses, the plexus of Anerbach, which lie- between the two layers of the muscular cout, and the plexus of Mei-sner, situated in the submueons coat. From these plexuses fithes are dis- 
tributed to the murcles and other structural clements. These fibres are of the non-medullated variety.

The nerves of the pancreas are also non-medullated, possess a few gamglia within the organ, and are finally distributed among the epithelial cells.

The Tonsils, Lymph-follicles, and Peyer's Patches.-These collections of lymphadenoid tissue in the alimentary tract have special

FIG. 131.

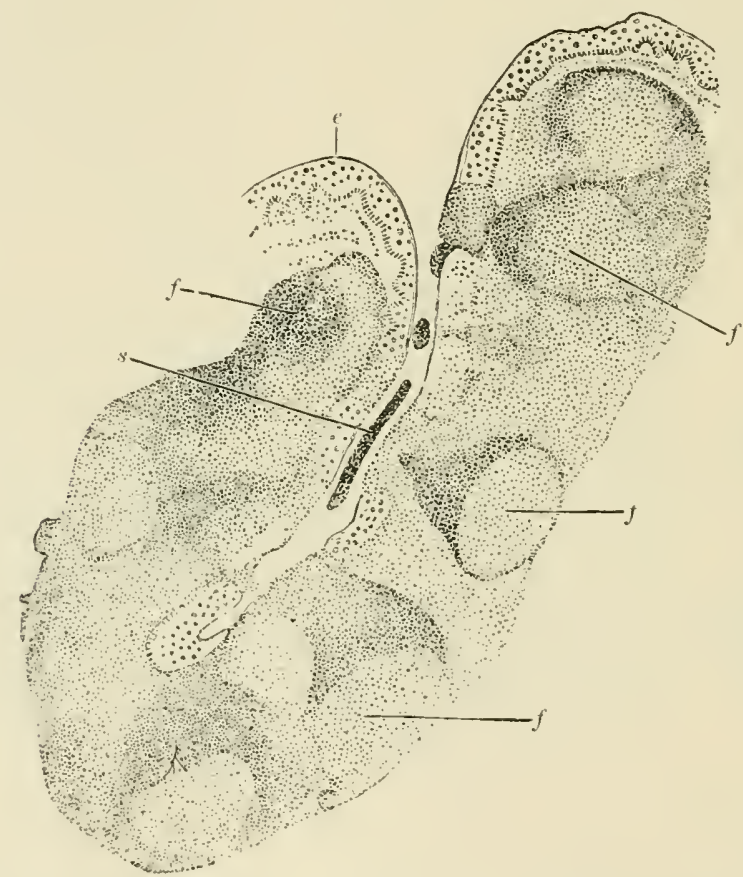

Section through one of the erypts of the tonsil. (stöhr.) $\epsilon$, stratified epithelium of the general surface, continued into the erypt: $f$, follicles containing germinal foci. Between the follieles is a more diffusely arranged lymphadenoid tissuc. s, material within the erypt, eomposed in part of lymphoid corpuseles that have wandered through the stratified epithelium.

interest to the physician as being points particularly liable to infection. The solitary follicles of the stomach and of the small and large intestine, and the collections of snch follicles forming the patches of Peyer, are the sites which are most vulnerable to invasion ly pathogenic bacteria in the digestive tract, though they are probably protected to a considerable extent by the germicidal powers of the acid gastric juice. This is not always eapable of grarding them from infection by the typhoid and tuberele bacilli, 
and in the diseases of the intestinal canal oceasioned by those bacteria the follicles and Peyer's patches are the seat of the earliest and most extensive nlcerations. The tonsils, which have the same gencral structure, are still more prone to infection of varions kinds, for they are more direetly exposed to the action of bacteria that may sain access to the montl.

The reason for this vuhnerability appears to lie in the close proxinity of the lymphaties to the surface and their meagre protection by a thin layer of epithelimm liable to abrasion or destruction. The solitary follicles of the intestine, for example, are eovered with a single layer of colummar epithelium (Fig. 128).

The lymphadenoid tissue of the tonsil, it is true, is protected by a layer of stratified epithelium ; but the surface of the tonsil is invaginated to form the erypts of that organ, and within those crypts it

FI ${ }^{\prime}$, 13:2.

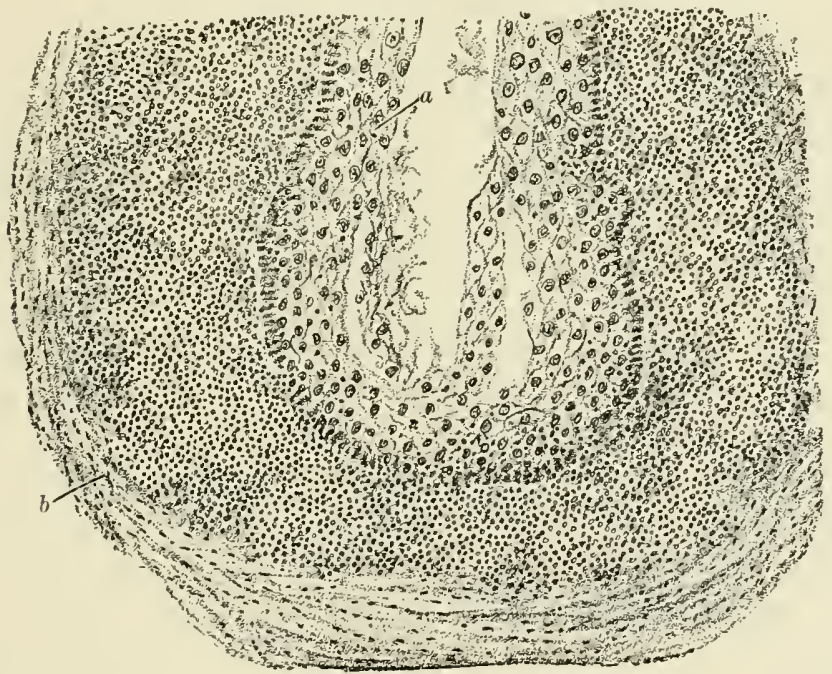

Section through the fundus of a crypt. (Benda and Guenther's Allas.) $a$, stratified epithelium, desquamating at its surface; $b$, deep portion of the lymphadenoid tissue, in which proliferation of lymphoirl cells takes place as well as in the follicles represented in Fig. 131 .

is presible for bacteria to multiply and produce such an accumulation of poisonous products as to destroy the integrity of the epithelinm and so permit an invasion of the lymphadenoid tissue beneath. We therefore find the tonsils specially prone to such inftammatory processes as tonsillitis and diphtheritic inflammation (Figs. 131 and $132)$. 


\section{CHAPTER XI.}

\section{THE LIVER.}

Trat portion of the liver which is exposed in the abdominal cavity is covered by a reflection of the peritoneum, closely attached to the organ, because its deeper side is continuons with the fibrous structures or interstitial tissue of the liver itself. This serous covering is so thin that the substance of the liver can be readily seen through it.

At the portal fissure, the serous coat having been reflected from it, the liver is covered witl a loose areolar tissue in which the main trunks of all but one of the ressels comnected with it are situated: namely, the portal rein, hepatic artery, gall-duct, and lymphatics. These ressels enter the liver together at this place, and are closely associated with each other in all their ramifications, being supported throughout by areolar tissue, which is continuous with that at the portal fissure and with the interstitial tissue of the liver.

These ressels, with their supporting fibrous investment, called Glisson's capsule, ramify in the liver in such a way as to resemble a tree with a multitude of branches and twigs, each composed of divisions of all the ressels named.

The hepatic vein enters the liver at a different place, and also suffers a tree-like subdivision; but its branches are surrounded by a very much smaller amount of fibrous tisune, which may be regarded as but a slightly reinforeed portion of the interstitial tissue of the organ.

Sections of the liver (Fig. 133) will reveal portions of these two trees, cut in various directions with respect to their axes. It will be ohserved that the twigs and larger branches of the trees are nowhere in close relations to each other, showing that the hepatic vein, in all its ramifications, is separated from the other vessels by the parenchyma of the organ. If we select some part of a section which contains one of the smallest branches of the hepatic rein, and cut across its axis so that its lumen appears romul, we shall notice that at about equal distances from it there are sections of two, 
three, or four twigs of the compound tree. In these the gall-duct can be identified by its distinct lining of columnar or cubical epithelium, and the hepatic artery distinguished from the portal vein by its relatively thick wall as compared with the size of its lumen. These vessels are collectively known as the interlobular vessels. Between and around them is the areolar fibrous tissue, which forms a part of Glisson's eapsule, and which is abundantly supplied with

FIt. 133.

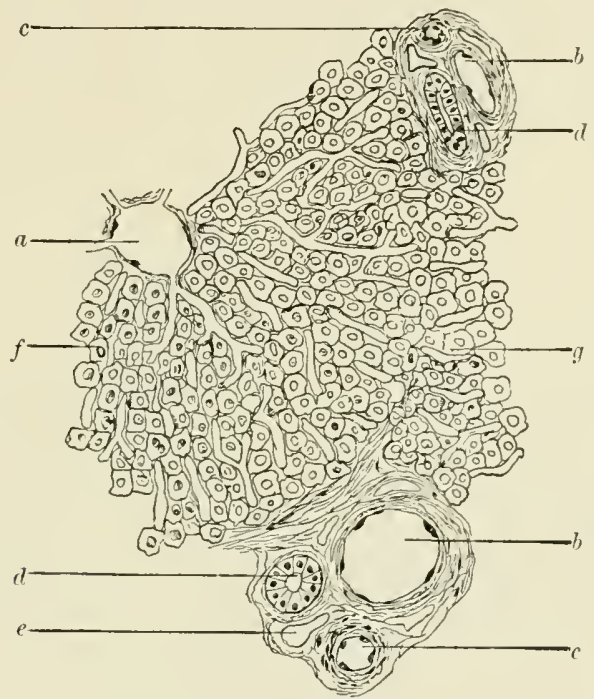

Diagrammatic sketch of a section of liver: $a$, central vein (radicle of the hepatic vein); $b, b$, branches of the portal vein; $c, c$, branches of the hepatic artery; $d, d$, small bile-ducts; $e$, lymphatic ressel $: b, c, d, e$ are enclosed in areolar tissue, which is continuous with Glisson's eapsule; $f$, liver-cells; $g$, line indicating the junction and blending; of two neighboring lobules.

lymplnatic spaces and ressels in the fibrous tissue. The lymphaties appear as clear spaces with smooth walls, some of them with distinct endothelial linings, but almost devoid of any other wall.

The parenchyma may be subdivided into portions which surround the smallest branches of the hepatic rein, and are bounded by imaginary lines connecting the gromps of interlobular ressels. These subdivisions are called "lobules" of the liver. In the human liver they blend at their peripheries, hetween the masses of connective tissue enclosing the interlobnlar ressel; but in the liver of the pig these lobules are veritable subdivisions of the liver, and 
are separaterl by septal of fibrous tissuc, the interlobular vessels lying in the lines formed by the junetion of three such septa.

Connecting the branches of the portal rein with the hepatic vein is a plexus of eapillaries, called the intralobular ressels, through which the blood passes from the portal vessels to the radicles of the hepatic vein and thence into the general cirenlation. These intralobular ressels also receive blood from the hepatie artery, the capillaries from which join them at a little dlistanee from the periphery of the lobule. The radicles of the hepatie vein are called the central reins, from their situation in the axes of the lobules, which are conceived as having a somewhat eylindrieal shape (Fig. 134).

FIf. 134.

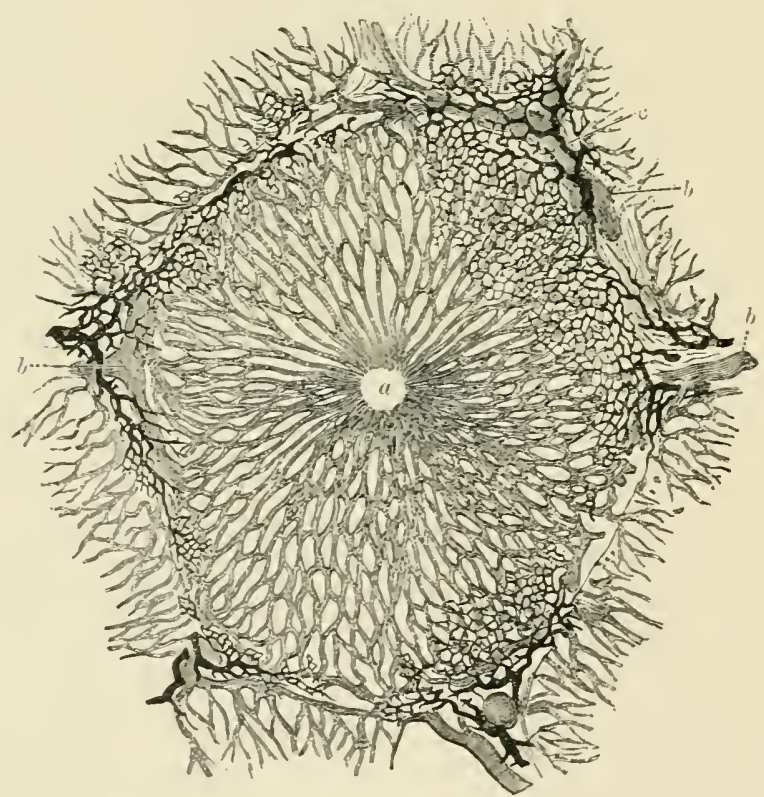

Vessels and bile-ducts of a lobule of a rabbit's lircr in transverse section. (Cadiat.) $a$, central vein $; b, b$, interlobular veins (branches of the portal rein) : $c$, interlobular bile-duct, receiving capillary bile-ducts from the lobule. Between $a$ and $b$ is the capillary plexus called the intralobular vessels. The biliary radicles are not represented throughout the figre, and the branches of the hepatic artery have been wholly ounitted.

Between the interlobular capillaries are rows of epithelial eells, which constitute the functional part of the liver, its parenchyma. They appear to touch the wall= of the capillaries, but are, in reality, separated from them by a narrow lymph--pace (Fig. 135). In the 
human liver the epithelial cells of the parenchyma form a plexus lying in the meshes of the capillary network of the interlobular vessels.

It requires an effort of the imagination to conceive of a third plexus within the lobule, but such a plexus exists, being formed of the radicles of the gall-duct. These are minute channels situated between contignous epithelial cells, each of which is grooved upon its surface to form half of the tiny canal. The cells themselves have fine channels running from the bile-capillaries into their cytoplasm and ending there in little romnded expansions. It is difficult to detect these bile-eapillaries in ordinary sections of the liver, unless they have been previously injeeted throngh the main duct; but with a high power their cross-sections may sometimes be elearly seen, appearing as little ronnd or oval spaces at the junction of two

Fig. 135.

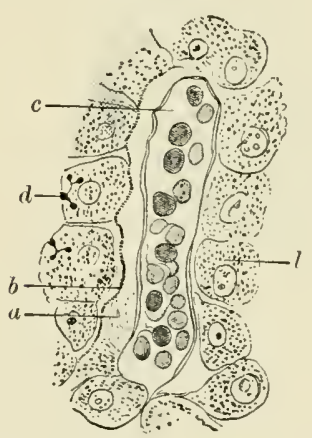

FiG. 136 .

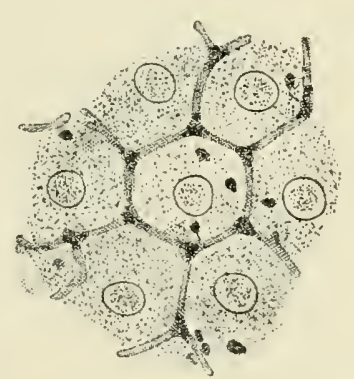

Fig. 135,-Perivascular lymphatic of the human liver. (Disse.) c, capillary in longitudinal section; $a$, lymphatic space between the capilary and row of epithelial cells; $b$, wall of the lymphatic space, slightly separated from the liver-cells and drawn a little emphatically; $l$, liver-cells; $d$, bile-capillaries in cross-section, with their intracellular ramifications.

Fig. 136,-Bile-rapillaries between the liver-cells, with minute channels penetrating the cells and communicating with secretory vacuoles within the cytoplasm. 1njected liver of the rabbit. (Pfeiffer.)

epithelial cells, midway between the nearest capillary bloodressels. Throughout their whole course they appear to be separated from the nearest bloodvessels by a distance approximately equal to lalf the diameter of one of the epithelial cells. It is this fact that makes it so difficult to frame a mental picture of their distribution in the lobule (Fig. 136).

The nerves supplying the liver ramify in extremely delicate, non- 
medullated fibrils, which ramify thronghont the substance of the liver and terminate in minnte twigs among its epithelial cells.

The epithelial cells of the liver have a cubical shape, the grooved and other surfaces that come in contact with neighboring cells being flat, while the remaining surfaces may be somewhat rounded. The cytoplasm is granular, and, except after a considerable period of starration, more or less abundantly infiltrated with irregular granules and masses of glycogen and globules of fat (Fig. 137). The

FIG. 137.

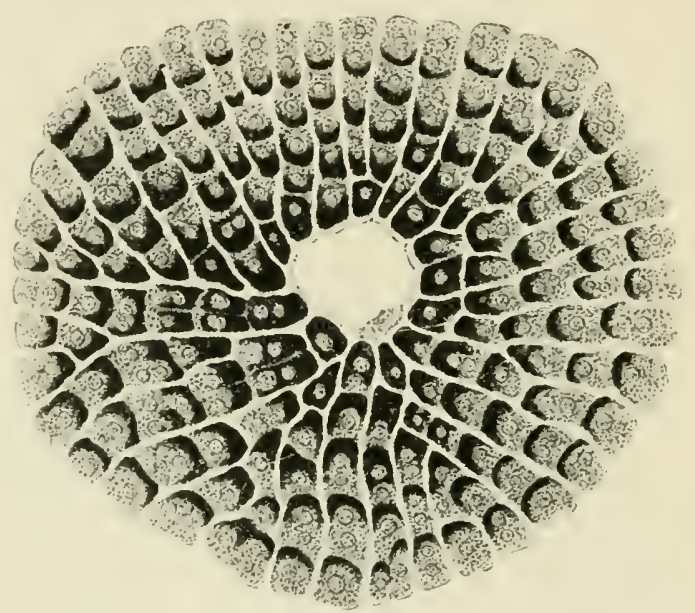

Portion of hepatic lobule of the rabbit; cells infiltrated with glycogen. (Barfurth.) The animal had been fed for twenty-four hours on wheat-bread, to promote the storage of glycogen within the liver-cells. The cells in close proximity to the central rein contain the largest amount of glycogen, which appears to fill the cytoplasm. Further from the central vein the cells contain less glycogen, which is most abundant in that portion of the cell turned toward the centre of the lobule. Fat-globules are most abundant in the cells at the periphery of the lobule. No fat-globules are represented in this figure.

glyeogen dissolves out of the cells during the ordinary processes of fixation and hardening preparatory to the preparation of sections, leaving spaces in the crtoplasm, which canse it to have a coarsely reticulated appearance in eases where the glyeogen was abundant. This reticnlation wonld render it impossible to distingnish the minute intracellular bile-passages. Fich cell has a round resicular melens near its centre. In rare instances two nuclei may be found in a single eell. The functions of the liver are so varied and involve such eomplex chenical traneformations that the liver-cell must be considered as a structure of marrellous activity. It stores carbohydrate food-stuff', transforming sngars into grlycogen, and converts 
this substauce into dextrose as occasion requires. It also stores fiuts, rexerving them for the needs of the organism. It elaborates the bile-salts and pigment, deriving matrrial for the latter from the hremoglobin of the blood. In adclition to these functions, many synthetical processes oceur in the liver. The nitrogenous wasteproducts of metabolism in other parts of the hody are here changed into forms suitable for excretion by the kidner. Most of the urea appearing in the urine is formed in the liver. Injurions substances absorbed from the intestine are, at least in many instances, combined in the liver with chemical radicals to form less toxic compounds which can be climinated. It therefore exerts an important detoxieating influence highly beneficial to the other organs and cells of the body. In view of these numerous functions and the great versatility displayed by the liver-cells, it is not sumprising to find that by special methods of preparation very diverse structural appearances are presented by these cells, and that these appearances vary with the condition of the liver at the time of its removal from the body. Some observers believe that the intercellular bilo-radieles describer by others are artefacts, and not permanent structures. Some investigators have ascribed anceboid movements of limited range to these cells, and have noted the presence of red blockcorpuseles within the eytoplasm, apparently incorporated by active movements of the eell-body. Injections have even heen made to penetrate the nucleus. Diversities in apparent structure, of which these are morely a few examples, render it impossible to give a brief arlequate resoription of the typical liver-cell or to connect definitely the observed structures with any particular function.

It will, perhaps, make the structure of the liver a little more comprehensible if it is stated that the liver of some of the lower animals is a tubular gland, the tubes of which are lined witls a layer of epithelium. In the lumman liver this tubular strueture is disguised by the facts that the tubules anastomose with each other, and that their Immina are very minute and bounded by only two eells when seen in cross-section. So inconspienous are these lumina that a casual glance at a section of a liver would not reveal the fact that it was a glaudular organ.

The interstitial tissue of the liver consists of a few sparsely distributed fibres continuous with those of Glisson's eapsule.

The intricate strueture of the liver prepares us for the fact that its function is an extremely complex one. It is a secreting gland, 
chaborating the bile and discharwing it iuto the duodenum. But the bile has more than one purpore. It aids in the digestion and absolption of food, and it also contains excrementitions matters destined to leave the body throngh the alimentary tract. Even the sceretory function of the liver, therefore, scrves a double purpose: the supply of substances useful to the organism and the elimination of products that would be detrimental if retained.

But the function of the liver is not eonfined to the elaboration of the bile. It also acts as a reservoir for the storage of nourishment, which can be drawn upon as needed by the organism. This is the meaning of the glyengen and fat which have infiltrated the cells.

The food-materials that are albsorled from the digestive tract pasinto the system through two ehannel: : the lymphatic and the portal cireulations. The latter carries them to the liver, where some of the fat, probably after desaponifieation, is taken up by the epithelial cells, which also appropriate a portion of the sugar in the portal blool, transforming it into glveogen and holding it in that form until a relative deficieney of glueose in the blood reveals its need by the srstem.

The blool comes into snch elose relations with the epithelial cells of the liver that an interehange of soluble substances between them appears to be about as easy a matter as the interchange of gases between the blood and the air in the lungs; and, as in the latter case, this interehange is mutual: some matter pasing from the blood to the liver-eells and some from the eells to the blood. In the hung there is a ga-eons regeneration of the blood ; in the liver, a renovation as to certain of its soluble constituents.

The Gall-bladder.-The bile is secretel continuously by the liver, for it is an excrement; but it is discharged intermittently into the alimentary tract, as required by the digestive processes. In the interval it is stored in the gall-biadder.

The gall-bladder is lined with columnar epithelium, eapable of seereting muens. Beneath this is a layer of fibrons tissue, which beeomes areolar and supports the chicf blook vessels and lymphaties. A few gland opening into the gall-hadder are oreasionally present in this tissue. Beneath this is the wall of the orean, composed of interlacing bands of fibrous and smonth muscular tis-nes. The surfare is invested by a portion of the peritoneum. The excretory bileduct has a similar structure. 


\section{CHAPTER XII.}

\section{THE URINARY ORGANS.}

TuE urine is secreted by the kidney, whence it passes suecessively through the renai pelvis, ureter, bladder, and urethra into the outer world.

1. The kidney is made up of homologous parts or lobes, which are readily distinguished in early life by the superficial furrows marking their lines of junction. In later years these depressions on the surface of the kidney disappear. Each of the lobes corresponds to one of the papillie of the kidney and the pelvic calix that embraces it. In some of the lower animals-e.g., the rabbit-the kidney has but one papilla, so that the whole renal pelvis in those animals corresponds to a single calix in man.

The kidney is a compound tubular gland of peculiar construction, the tubules taking origin from little spherical bodies, called Malpighim bodies, instead of from simple blind extremitics, and, after rumning a definite and somewhat complicated course, uniting successively with several others to form the excretory ducts, called the "collecting tubules," which open into the ealices near the tips of the papillæ.

If a section of the organ be made throngh its convexity down to the pelvis, the papillæe will be seen projecting into the calices of the pelvis, and it will be noticed that each papilla forms the apex of a pyramidal portion of tissue having a different tint and textnre from the rest of the kidney. These pyramids form the "medulla" of the organ (Fig. 138).

The bloodvessels supplying nearly all its substance enter the kidney near the bases of the pyramids, having approached the organ through the fat that lies around the calices. Within the kidney they break up into branches that rum along the base of each pyramid in that portion of the organ which is called the "boundary zone." Between that zone and the convex surface of the kidney the tissue is known as the "cortex."

The arrangement of the renal tubules, which make up the chief 
bulk of the kidney, can be most easily understond if they are traced back from their openings: at the apex of the pyramid to their

Fig. 138 .
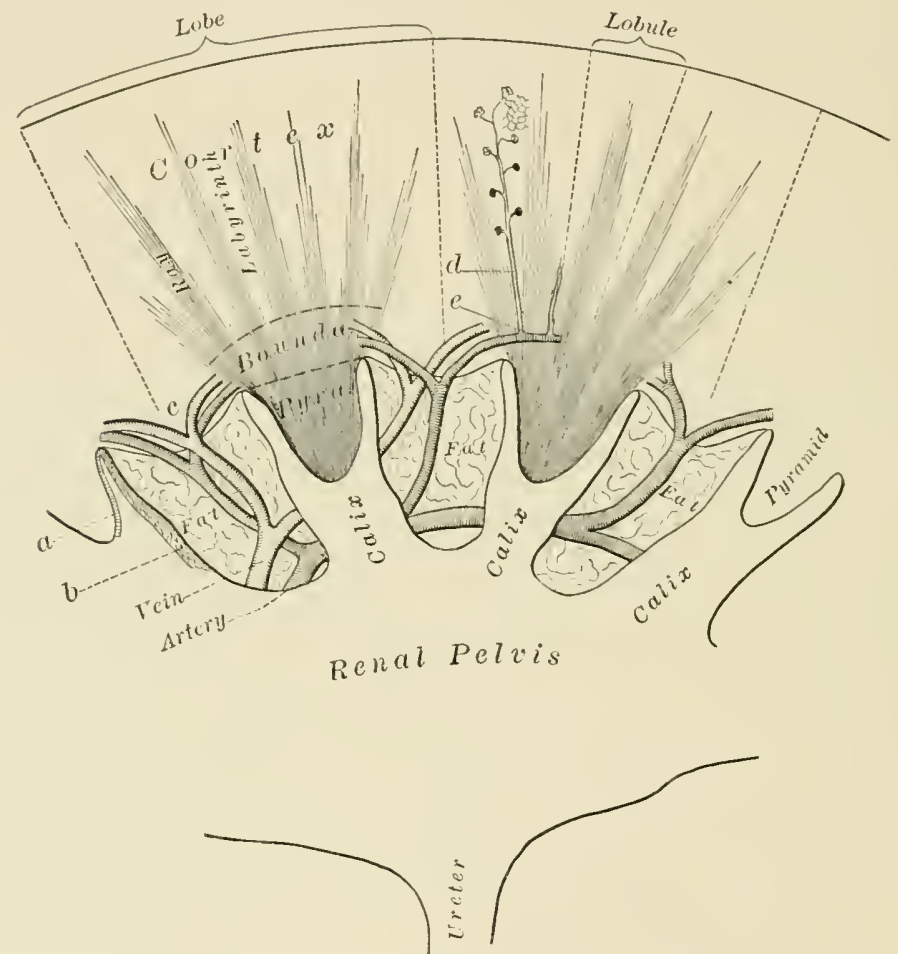

Diagrammatic sketeh of a section of the kidney: $a$, columnar epithelium eovering the external surface of the pyramid and continuous on the one hand with the eolumnar epithelium lining the eollecting tubules within the pyramid, and on the other hand with the transitional epithelium lining the calices and renal pelvis. This transitional epithelium is indicated at $b$. It rests upon the fibrous tissue of the caliees and relvis, which becomes eontinuous with the fibrous capsule of the kidney at the junction of the ealices with that organ. Outside of this capsule is the perinephric fat, indieated in the figure between the ealices. The vessels approach the kidney through this fat, entering its substance near the bases of the pyramids and forming the vascular arcades ( $e$, arterial arcate). From these areade's the interlobular ressels proceed, between the medullary rays and in the labyrinth, toward the convex surfaee of the kidney, $d$, interlobular artery, giving off lranches, the afferent ressels, to the Iraluighian bodies. The extensions of the cortieal substance between the pyramids, e, are known as the columns of Rertini. During infaney the lobes of the kidney are maried by sulci upon the surface of the organ. With the growth of the organ these lobes blend with each other, and the sulei hetween them become indistinct or are wholly olliterated. The columns of Bertini are made up of the blended lateral portions of the cortex of two contiguous lobes.

origins in the Malpighian bodies. The different portions of the tubules present somewhat different characters, and have received special names. 
The collecting tubes, which open into the ealix at the apex of the pramid, are straight, and lie nearly parallel to each other and to the axis of the pyramid, and, therefore, nearly perpendieular to the base of the pyramid. As they are followed from the apex, in a direction the reverse of that taken by the urine in flowing through them, they branch dichotomously, and the branches beeome progressively smaller. At the base of the pyramid these straight tubules are colleeted into bundles that radiate toward the convex surface of the kidney, and are called the "medullary rays." In these, and in the part of the pyramid that is near the boundaryzone, the eolleeting tubes are associated with other straight portions of the tubules, "Henle's tubes," which will be deseribed presently. From the medullary rays the tubules pass into the region between those rays in the cortical portion of the kidney. This region of the eortex is known as the "labyrinth." Here the tubules lose their straight character and become much contorted, forming the "second convoluted tubules." They then re-enter the medullary rays, which they deseend for a variable distanee into the pyramid, constituting the "ascending branches of Henle's tubes," which make a sharp turn, "Henle's loop," and then retrace their course up the medullary rays into the cortical portion of the kidney, "descending branches of Henle's tube." They then pass again into the labyrinth and form the "first convoluted tubules," which finally merge into the strueture of the Malpighian bodies, also situated in the labyrinth. In eonsequence of the passage of tubules from them into the surrounding labyrinth the medullary rays become smaller as they are followed from the base of the pyramid, and eventually disappear before the calpsule of the kirlney is reached. They are completely surrounded by the labyrinth.

If we now follow the course of the urine in its way from the Malpighian body to the outlet of the tubule, we shall find that it pases throngh the following divisions of the tubule: 1 , the "first convoluted tubule ;" 2, the "deseending branch of Henle's tule ;" 3, "Henle's loop ;" 4, the "ascending branch of Henle's tube ;" 5 , the "second convoluted tubule;" 6 , the "collecting tube." Of these, the two eonvoluted tubules are situated in the labyrinth; all the rest in the medullary rays and pramid. All of the portions, with the exception of the convoluted tubules and the loop, are straight and lie parallel to each other (Fig. 139).

Before entering more partieularly into the strueture of the renal 
Fig. 139.

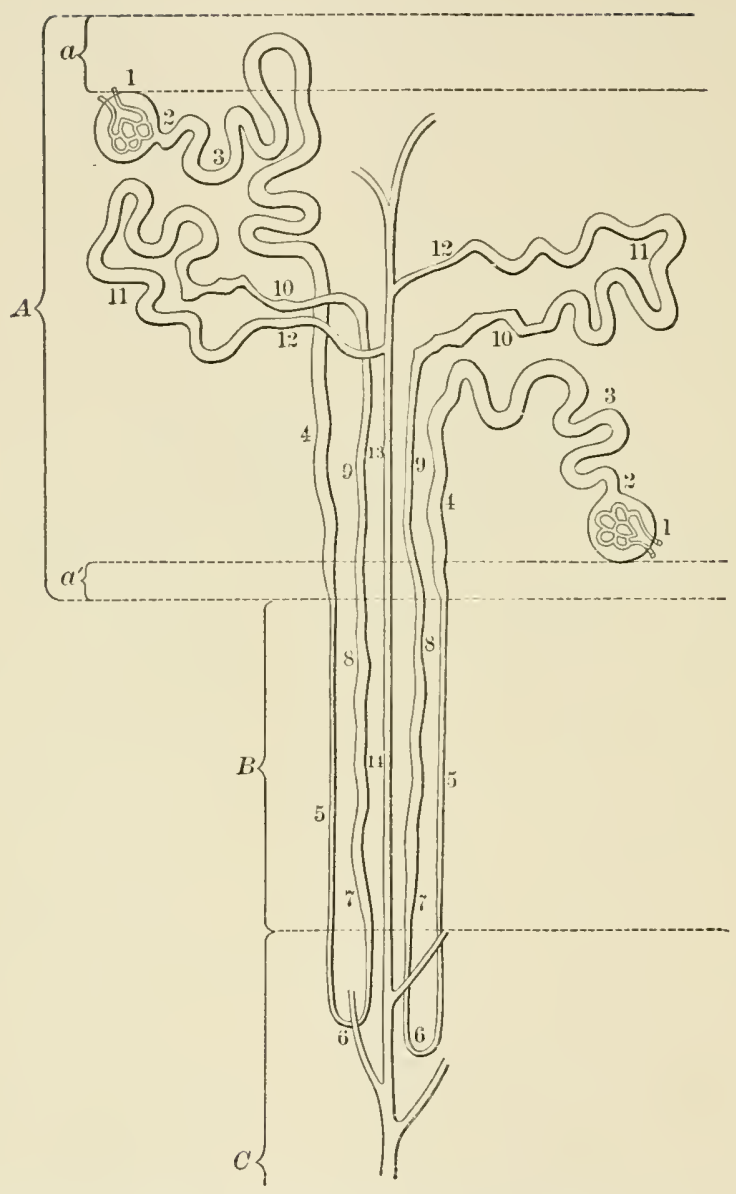

Diagram showing the course of the renal tubules within the kidney. (Klein.) $A$, cortex: $a$, subcapsular portion destitute of Malpighian bodies; $a^{\prime}$, inner portion, also devoid of Malpighian bodies. $B$, boundary. $C$, portion of the medulla at the base of the pyramid. 1 , Bowman's capsule surrounding the glomerulus; 2 , neck of the cajsule and beginning of the uriniferous tubule; 3 , first convoluted tubule; 4 , spiral portion of the first convoluted tubule in the medullary ray; 5 , descending limb of Henle's tube; 6 , Henle's loop; $7,8,9$, ascending limb of Henle's tube; 10, irregular transition to the second convoluted tubule; 11 , second convoluted tubule; 12, transition from second convoluted tubule to the collecting tubule; 13,14 , collecting tubule, joined below by others to form the excretory luct, which opens at the apex of the pyramid.

tubule, it will be best to conplete this general sketch by considering the course of the bloodvesich.s.

As has already been said, the ressels enter the kidney between the ealices and pyramids and are distributed in branches that lie 
parallel to the bases of the latter, and, therefore, to the convex surface of the organ, and are sitnated in the boundary-zone. The

FIG. 140.

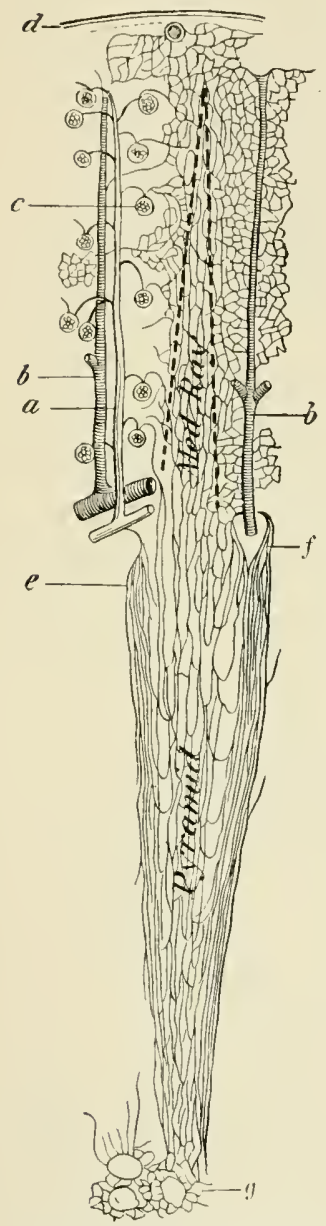

arterial branches in this location form the "arterial arcade." From this arcade perpendienlar branches, the "interlobular arteries," pass toward the capsule, taking a straight course through the labyrinth between the medullary rays. In this comrse they give off branches, the "afferent vessels," which go to the Malpighian bodies.

FIG. 141.

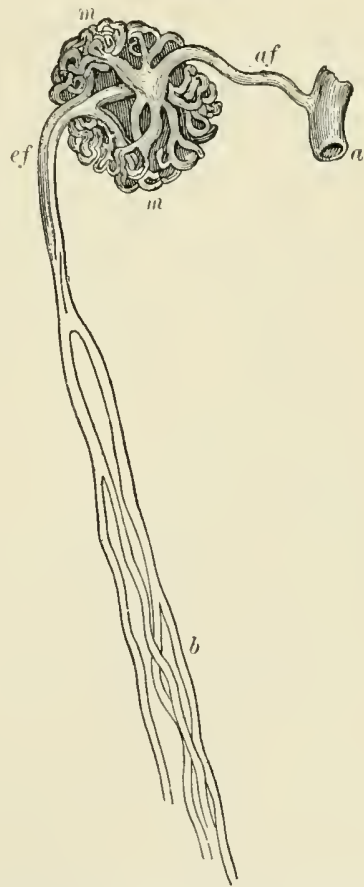

Fig. 140.-Diagram showing the course of the bloodvessels within the kidney. (Ludwig.) $\alpha$, interlobular artery; $b$, interlobular vein; $c$, Malpighian body, with the afferent vessel entering it from the interlobular artery, and the efferent vessel leaving it to take part in the formation of the capillary plexus between the renal tubules; $d$, vena stellata; $e$, arteriæ rectæ; $f$, venæ recte; $g$, capillary plexus around the mouths of the excretory duets.

Fig. 141.-Injected glomeruIus from the horse. (Kölliker, after Bowman.) a, interlobular artery; af, afferent vessel; $m, m$, capillary loops forming the glomerulus; $c f$, efferent vessel; $b$, capillary network in the labyrinth and medullary rays.

The main artery becomes smaller in giving off these branches, and finally ends in terminal afferent vessels (Fig. 140). 
Within the Malpighian body the afferent vesel divides abruptly into a number of capillary loops, which are compacted together to form a globular mass, called the "glomerulus" (F"ig. 141). These loops rejoin to form the "efferent" vessel, which is somewhat smaller than the afferent ressel, and leaves the Malpighian hody at a point close to that at which the afferent vessel enters it.

FIG. 142.

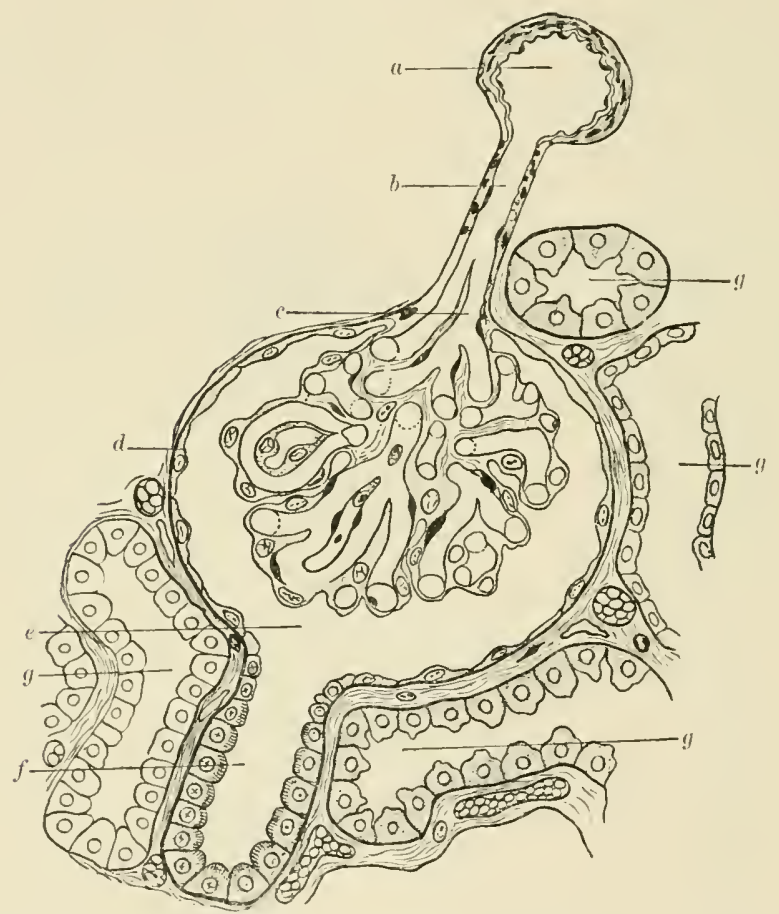

Sketch of a Malpighian boly from kidney of a rabbit: $a$, interlobular artery; $b$, afferent vessel; c, capillary springing from afferent ressel; $d$, Bowman's capsule, with epithelial lining reflected upon the surface of the glomerulus; $c$, eavity of the capsule into which the watery constituents of the urine are first discharged; $f$, beginning of a uriniferous tubule; $g$, eonvoluted tubules of the labyrinth. Between these tubules and the capsule are capillary bloodvessels derived from the efferent ressel (which is not shown, lut emerges from the capsule near the afferent vessel, on a different level from that represented). These and other structures are held in place by an areolar tissue, containing lymphatie spaces, some of whieh are rejresented.

Soon after leaving the Milpighian borly the efferent resel breaks up into a second set of eapillaries, which lie among the convoluted tubules of the labyrinth and also penetrate into the medullary rays, to be distributed between the tubules eomposing them. This eapillary network extends also into the pramid, in which the capilla- 
ries run, for the most part, parallel io the renal tubules, with eomparatively few transverse anastomosing branches. For this reason they have been called the "vasa reeta." They also receive blood from little twigs given off" from the arterial arcade.

The blood from the intertubular capillaries is collected in veins, which run a course parallel to that of the arteries and lie in close proximity to them. They have received names similar to those of the corresponding arteries: "interlobular veins," "venæ rectæ," and "venous arcade." Relatively large veins also leave the kidney from beneath the capsule on the convex surface of the organ. They are called the "stellate veins."

The Malpighian body is enclosed by a thin fibrous capsule (Bowman's capsule), which is perforated at two opposite points to permit the passage on the one hand of the afferent and efferent vessels, and on the other haud to allow of a communication between its cavity and the beginning of the uriniferous tubule. When distended with blood the glomerulus nearly fills this capsule, but when collapsed it is retracted toward the attachment formed by the ressels that picree the capsule. It is covered by a single laver of epi-

Fig. $1+3$

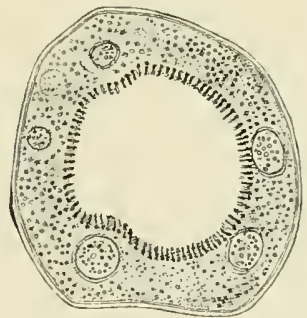

FIG. 144 .

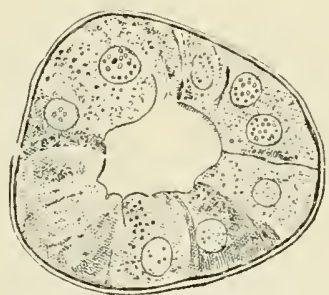

Cross-sections of convoluted tubules lined with cells in different states of activity. (Disse.)

Fig. 135.-From a criminal directly after execution. Cells in a state of rest. The cells are low and granular, and present a striation of their free ends resembling cilia.

Fig. 136.-From a cat. The cells are enlarged, because charged with material to be excreted, and the striated border is nearly obliterated. Similar appearances have been observed in the human kidney. In one of the lower cells in this figure a faint striation of the attiched end is just discernible. This increases in distinctness as the cell becomes surcharged with cxcretory material, when the more central portion of the cytoplasm becomes hyaline and contains the nucleus.

thelial cells, which is reflected at that attachment and forms a lining for the inner surface of the capsule to the point where its cavity opens into the lumen of the renal tubule. Here the epithelial lining becomes continuous with that of the tubule (Fig. 142).

The different portions of the uriniferous tubule differ in their 
external diameters, the diameters of their lumina, and the character of their epithelial linings. The appearance of the epithelial cells differs, however, in accordanee with their state of functional activity (Figs. 143 and 144).

The first convoluted tubule is relatively large, and is lined with large epithelial cells, which project into the tubule albout one-thirel of its diameter. The eells have round muclei situated near their centres, and are granular, with an appearance of radiate striation in their deeper halves when charged with secretion.

The descending branch of Henle's tube has a smaller diameter, but its lumen is wide in consequence of the thimness of the clear epithelial cells lining it. In the ascending branch the lumen is again smaller, although the diameter of the tube is larger, because the lining cells are thicker, somewhat resembling those of the first convoluted tubule. The transition from the character of the descending to that of the ascending branch does not always take place exactly at the loop.

The second convoluted tubule is a little smaller than the first, and is lined with cells that are not quite so granular and a little more highly refraeting.

The collecting tubules are lined with eolumuar epithelinm, the cells of which become longer as the diameter of the tube increases in its progress toward the apex of the pyramid.

The epithelial lining throughout the course of the renal tubule is said to rest "1pon a thin, homogeneous basement-membrane interposed between it and the interstitial fibrous tissue. The latter is present in small amonnt, and partakes of the character of an areolar tissne, holding the tulules and bloodvessels in place. It is rather abundantly supplied with lymphaties.

For the study of the uriniferons tubules sections made transverse to the course of the straight tubules will be fonnd very nsefinl. In the cortex the medullary rays, with their descending and aseending branches of Henle's tubes and their collecting tubules, will appeas surromder by the labyrinth, made up of the convoluted tubules, Malpighian bodies, and larger vessels, the latter in cross-section. Near the alpex of the pyramid cross-sections of the larger colleeting tubes and of the vasa recta will be seen; and neat its bace the smaller collecting tubes and the two limbs of Henle's tube, with, pos-ibly, here and there a "loop" in nearly longitudinal section, will appear. Anong all these sections of the tubules the 
interstitial tissne with its capillaries and lymphatics will complete the pieture (Figs. 145 and 146).

FI(i. 145 .

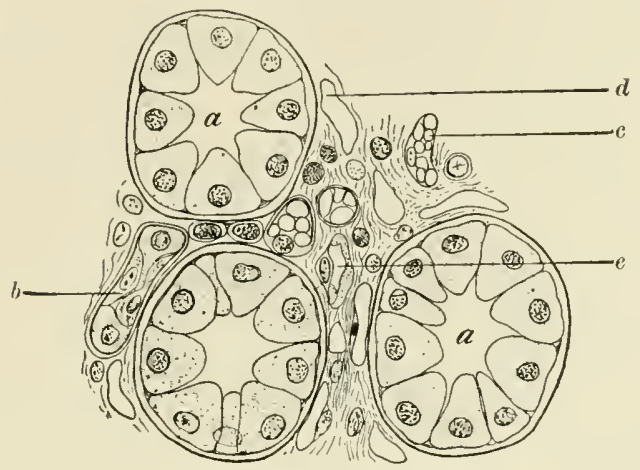

Fig. 146 .

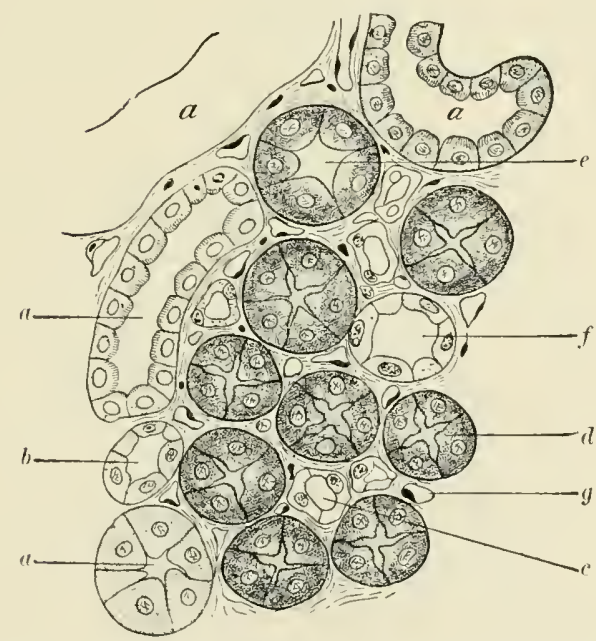

Sections from a rabbit's kidney, made perpendicular to the course of the straight tubules.

Fig. 14.5.-Through a portion of the pyramid: $a$, lower portions of the collecting tubules (excretory ducts); $b$, Henle's loop in tangential section; $c$, capillary bloodressels; $d$, lymphatic; $e$, descending limb of Henle's tube.

Fig. 146.-Through part of a medullary ray and the adjoining labprinth : $a, a, a, a$, convoluted tubules in the labyrinth; $b$, spiral tubule: $c$, descending limb of Henle's tube; $d$, ascending limb of Henle's tube: $e$, irregular tubule: $f$, collecting tubule: $g$, capillary bloodvessel.

The nerves of the kidney are small and apparently not abundant. Their larger branches follow the courses of the arteries. 
The external surfice of the kidney is covered with a eapsule of fibrous tissue, which on its deeper surfiee becomes continuous with the interstitial tissue, so that its vascular supply communicates with the capillaries in the superficial portions of the kilney.

The fibrous capsule of the kidney becomes continuous at the hilum of that organ with the fibrous eoats of the ealices and pelvis, and, through these, with those of the ureter and bladder.

The colnmnar epithelium lining the collecting tubes is continuous with a layer of similar cells covering the papillie.

The watery constituent of the urine is secreted in the Malpighian body, where it passes from the blood throngh the capillary walls of the glomerulus into the eavity of Bowman's eapsule. Under normal conditions it is free from albumin, and, therefore, is unlike the serum that passes through the walls of the capillaries in other parts of the body. It has been thonglit that this difference was attrib-

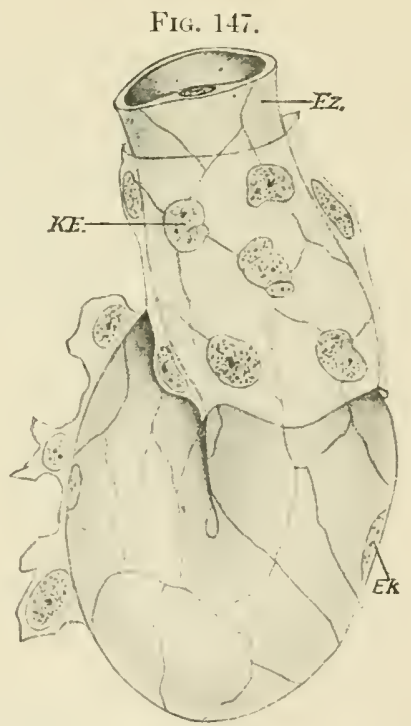

Capiliary loop from the glomerulus of the frog. (Nussbaum.) $E_{\approx}$, endothelial wall of the capillary bloodvessel; $E k$, nucleus of one of the endothelial cells (only three such nuclei are shown in the figure): $h E$, nucleus of one of the epithelial cells investing the capillary. The boundaries of these cells are not reproduced in the figure. At the left of the cut three epithelial cells have been partially reflected away from the capillary wall.

utable to the functional action of the endothelium in the glomerulus, though morphologically it is similar to that thronghout the body. It is more probable that the epithelium covering the glomerulus has 
something to do with the prevention of a loss of albumin (Fig. 147). In discase of the kidney, alterations in the glomerulus and, perhaps, in other parts of the kidney permit albumin to pass into the secretion.

The epithelium lining the uriniferous tubules discharges its secretion into the lumen of the tubules, whence it is earried by the stream flowing from the Malpighian bodies. The epithelial eells lining the convoluted tubules and the ascending branches of Henle's tubes appear to be those most aetive in carrying on the eliminative function of the kidney.

2. The pelvis of the kidney and its calices are lined with transitional epithelium. It consists of only three or four layers of epithelial cells of different shapes. The most superficial layer is composed of rather large flattened cells, having ridges upon their lower surfaces, which fill the spaces between the tops of the next layer. This is marle up of pear-shaped or caudate cells, the hemispherical tops of which fit into the eavities between the ridges on the layer above, while their slender processes penetrate between

Fifi. 148.

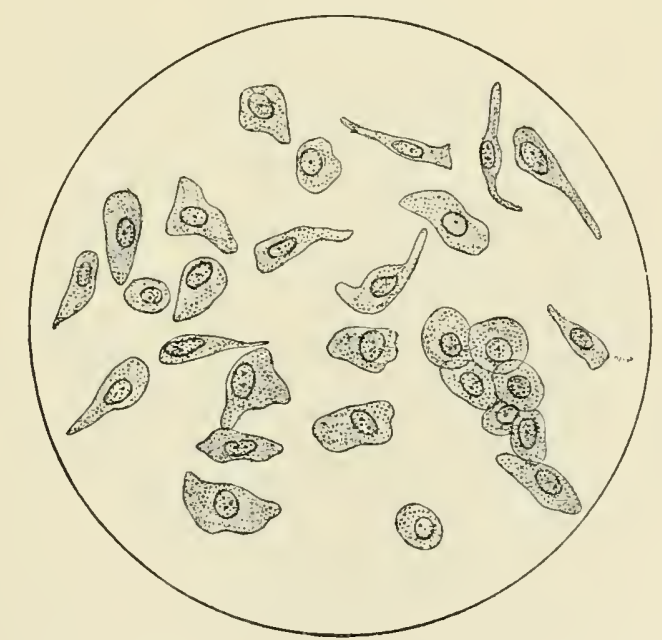

Epithelial cells from the pelvis of a human kidney. (Rieder.)

the oval or round cells that make up the deepest layers of the epithelial covering (Fig. 148).

Beneath the epithelium is a coat of fibrons tissue, denser near the epithelium and more areolar in its deeper portions. Here it is 
interlaced with smooth muscular fibres, ontside of which is the external coat of fibrous tissue.

3. The ureters closely resemble in structure the pelvis of the kidney; but the muscular fibres have a somewhat more definite arrangenent, being disposed in an inner imperfect coat of longitudinal and an external layer of cireular fibres, outside of which a few supplementary longitudinal fibres are, here and there, added (Fig. 149).

4. The bladder also has a lining of transitional epithelimm (Fig.

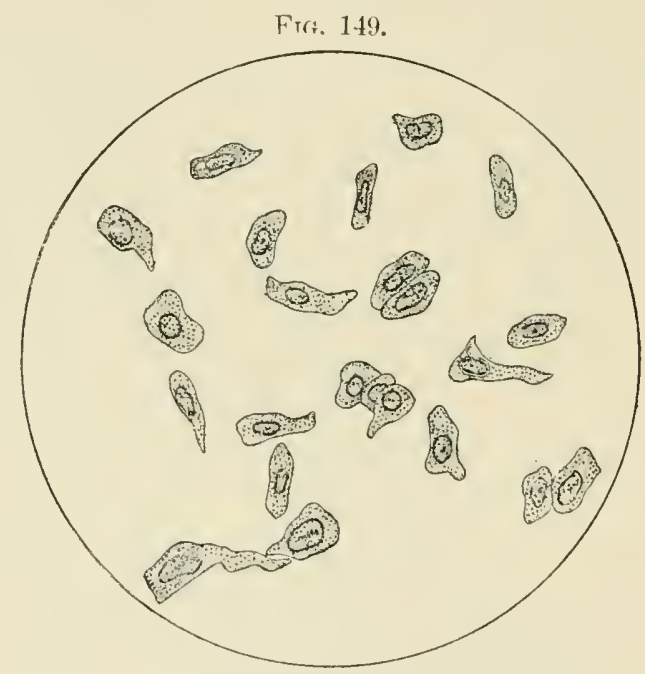

Epithelial cells from the human ureter. (Rieder.)

40 ), beneath which is a layer of fibrons tissue resembling that of the renal pelvis, but of greater thickness. The muscular coat, which comes next, is thick and composed of bundles of smooth muscular fibres, interlacing in varions direetions or disposed in more or less wetl-defined stratil. External to the musenlar eoat is a fibrons coat, which is covered by a refiection of the peritonenm for a part of its extent, and in other situations passes into the surrounding areolar tissue.

The spear-shaped cells of the transitional epithelinm of the bladder have thicker procesices than those of the pelvis or ureter; but when detached and macerater in the urine it is often very difficult to determine from their appearance from what part of the urinary tract such cells were derived (Figs. 150 and 151). 
5. The urethra differs in structure in the two sexes. In the male the prostatic portion is lined with epithelium resembling that

FI(i. 150.

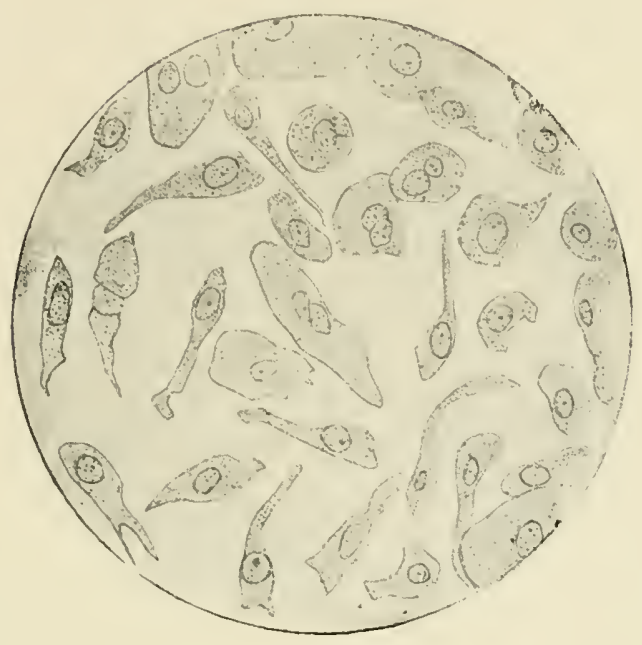

FIG. 151.

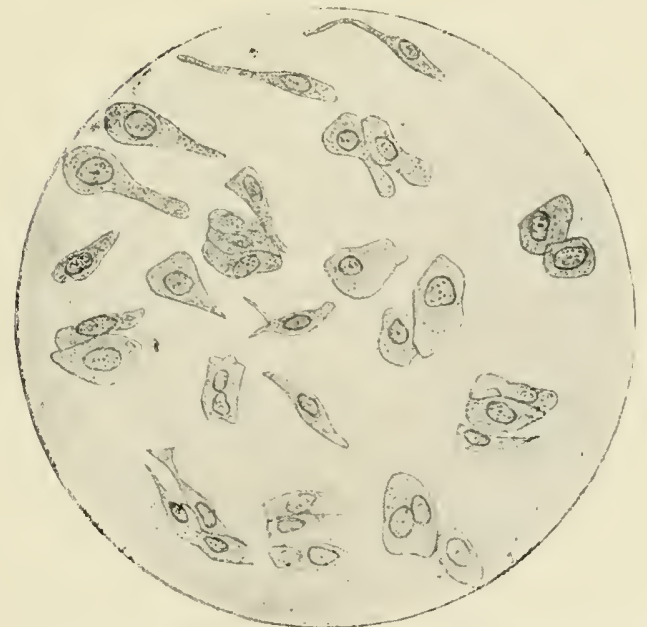

Epithelial cells from the mucous membrane of the human bladder. (Rieder.)

Fig, 150.-From the urinary sediment from a case of eystitis. The cells are somewhat swollen after maceration in the altered urine.

Fig, 151.-Removed from the internal surface of a normal bladder.

of the bladder. Further forward, it gradually passes into cylindrical epithelium, at first more than one layer thick; but in the 
cavernous portion of the urethra it eonsists of but a single layer. The stratified epithelium covering the glans extends for a short distance from the meatus into the mrethra (Fig. 152). The epithe-

FIF. 152.

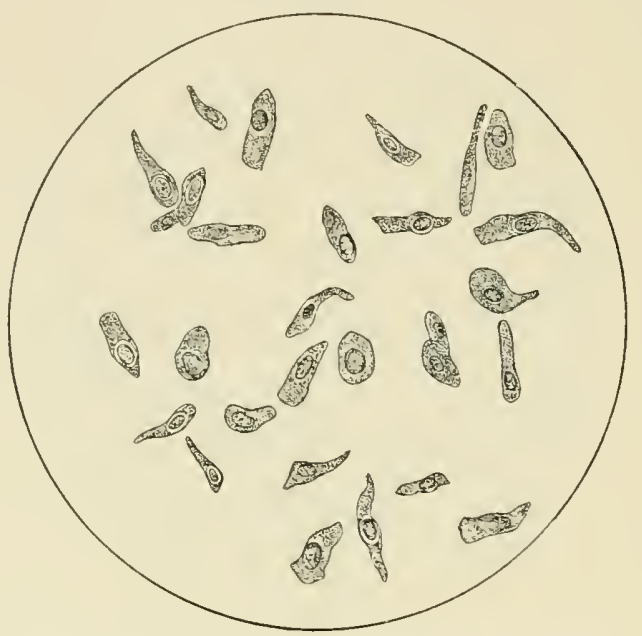

Epithelium from the human male urethra. (Rieder.)

lial lining rests upon fibrous tissue containing a number of elastic fibres, and this is bounded externally by a muscular coat. In the prostatic portion the muscular eoat eonsists of an inner longitudinal and an outer cirenlar layer of fibres, which become less well marked as the course of the urethra is followed, the tirenlar coat disappearing in the bulbons portion and the longitudinal fibres becoming scattered toward the anterior part of the cavemons portion. The mueous membrane contains little tubular glands, "Littrés glands," rome of which are simple, while others are compounded. In the collaped condition the urethral mucous membrane is thrown into one or more longitudinal fold:.

In the female the epithelial lining of the nrethra is either stratified or composed of a single layer of columnar cells. The glamels are more sparsely distributed than in the male, except for a group -ituated near the meatus. On the other hand, the muscular coat is thicker and consists throughout the conres of the urethra of a well-defined internal homgitulinal and external eirenlar layer of fibres.

From the pelvis of the kidney to the stratified epithelium of the 
meatus the mucons membranes are capable of seereting muens, which is much increased in amount under the influence of irritating substances, such ats eoncentrated urine or the various causes of inflammation. The bloodvessels are most numerous and of largest size in the areolar tissue beneath the epithelium, and are accompanied by the lymphaties. The nerves are distributed ehicfly to the muscular coats, but also extend into the fibrous tissue, up to and into the epithelium. The cells of the latter are conneeted by little protoplasmie bridges, as in the case of the epidermis, leaving minute chamnels between the colls for the passage of nutrient fluids. 


\section{CHAPTER XIII.}

\section{THE RESPIRATORY ORGANS.}

The respiratory tract consists of the larynx, trachea, bronchi, and lungs.

1. The Larynx.-The interior of the laryn is lined with ciliated columnar epithelium, which extends over the false vocal cords and about half-way up the epiglottis above, and is continuons below with a similar lining thronghont the trachea and bronchi. This lining is interrupted over the true rocal cords by a covering of stratified epithelium, and at its upper limits passes into the stratified epithelium lining the buccal cavity and pharynx and covering the tongue. Opening upon this epithelial surface, except upon the true vocal cords and in the smallest bronchi, are mucous glands, varying in number in different situations. Some of the columnar cells upon the surface are also mucigenous, discharging their secretion upon the free surfice of the mueons membrane.

The thyroid, cricoid, and most of the arrtenoid cartilages are composed of the hyaline variety of that tissue: the epiglottis, cornicula laryngis, and the apices of the arytenoids, of elastic cartilage.

Beneath the epithelinm lining the laryngeal ventricle is a considerable layer of lymphadenoid tissue. In other situations the epithelium rests upon fibrous tissue.

2. The Trachea.-The tracheal wall may be divided into four coats: a, the mucous membrane; b, the suburucous coat; c, the cartilage; d, the fibrous coat (Fig. 153).

a. The mucous membrane is covered with ciliated columnar epithelium resting upon a nearly homogeneous basement-membrane, beneath which is a layer of fibrous tissue. This may be divided into two portions: an onter one, next to the basement-membrane, which is areolar in character, with a large admixture of elastic fibres and lymphadenoid tissue, and an abundant supply of bloodressels; and an inner one, less highly vascularized, and composed chiefly of elastic fibres rmning a longitudinal course. 
6. The submucons coat is of areolar fibrous tissue, supporting the mucons grands that open into the trachea, and the bloodressels, lymphatics, and nerves, and also little masses of adipose tissue. In the neighborhood of the cartilages this fibrous tissue becomes condensed to form the perichondrim.

c. The eartilages are composed of the hyaline variety of that

Fig. 153.

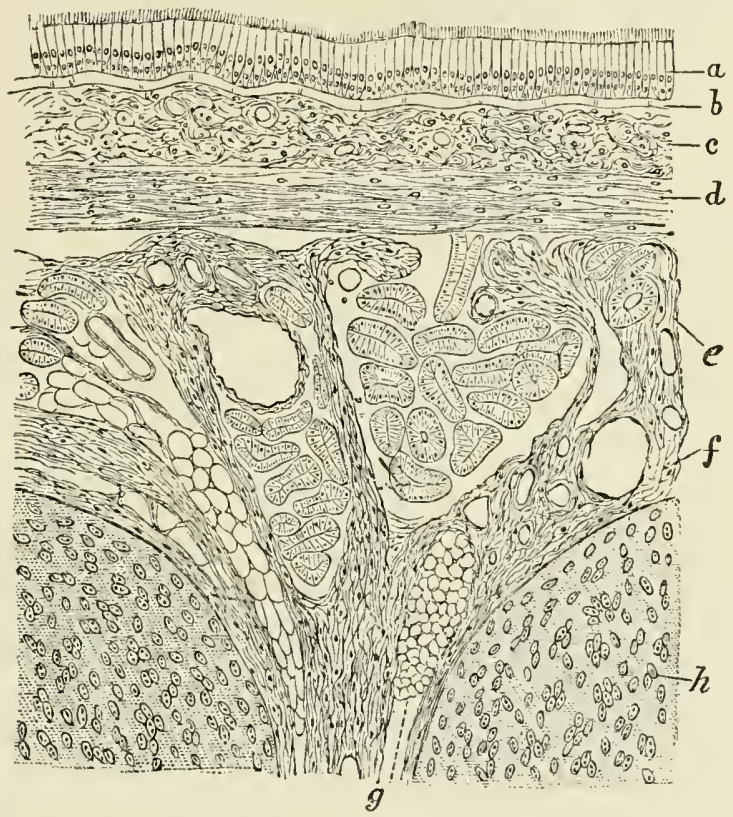

From a longitudinal section through the trachea of a ehild. (Klein.) $a$, the stratified columnar ciliated epithelium of the internal free surface: $b$, the basement-membrane $c$, the mucosa (tunica propria); $d$, the network of longitudinal elastic fibres (the oval nuelei between them indiente connective-tissue corpuseles); $e$, the submueous tissue, containing mucons glands; $f$, large bloodvessels; $g$, fat-cells: $h$, hyaline cartilage of the tracheal rings. (Only a part of the tracheal wall is given in the figure.)

tissue, and are incomplete rings, interrupted behind, where the two ends are united by a band of smooth muscular tissue.

d. The fibrons coat is of areolar tissue beyond the bounds of the perichoudrimm, and serves to commect the trachea with its surroundings.

3. The Bronchi.-The main bronchi branching from the trachea have a structure similar to that organ, but the cartilaginous rings become more delicate as the tubes diminish in size. 
The smaller bronchi differ in strueture from the trachea in possessing a muscularis mucose, with its fibres disposed in a circular direction, and having irregular cartilaginous plates in their walls, instead of C-shaped, imperfect rings. The four coats may be entmerated ats follows:

1. Mucons membrane, covered with ciliated columnar epithelium resting upon a basement-membrane, beneath which is a fibrous tissue containing numerous elastic fibres lying parallel to the axis of the bronchus. Under this are the circular fibres of the muscularis mucosie.

b. Submucons coat, similar to that of the trachea and larger bronchi.

c. Cartilaginous coat, containing the plates of cartilage that support the walls.

d. Fibrous coat of areolar tissue, containing a little adipose tissue and passing into the areolin tissue of neighboring structures.

As the bronchi subdivide and become smaller the coats get thinner, and first the cartilaginous and then the muscular coat disappears. Those air-passages which are withont cartilage, but have

\section{FIเі. 154.}

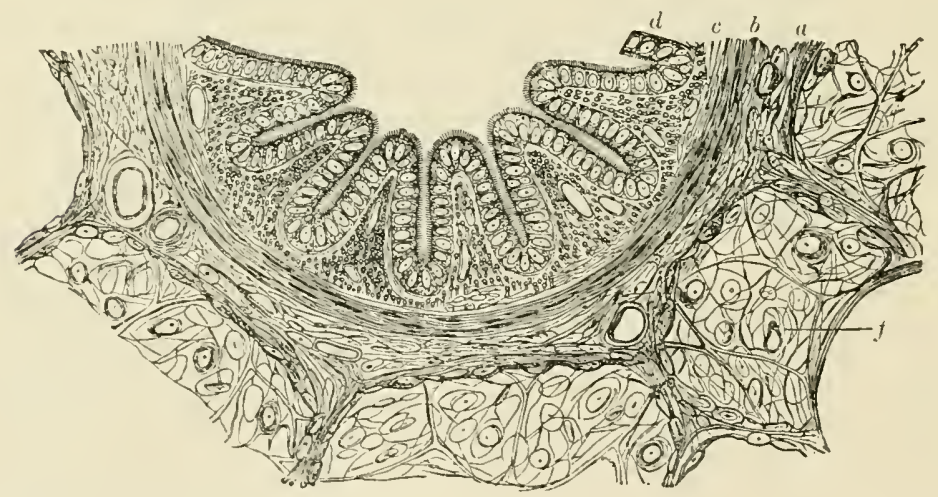

Portion of a cross-section of a bronchiole from the lung of a pig. (Schultze.) a, areolar external coat; $b$, muscularis mueose : $c$, subepithelial a reolar tissue, containing numerous longitudinal elastic fil,res, represented here in cross-section; $d$, ciliated epithclium, forming the most superficial layer of the mucous memhrane: $f$, walls of the neighboring pulmonary alveoli. In these walls branching and anastomosing elastie fibres are shown; the capillary plexus has been omitted.

a muscularis mucose, are called "bronchioles" (Fig. 154). The still smaller branches, which have lost their muscular tissue, are known as the "alveolar passages." In the latter the colummar 
epithelium lining the bronchi gives place to a pa vement-epithelium, composed of small flattened cells disposed in a single layer. The elastic tissue of the mucons nembrane is continued through all the divisions of the air-passages, and becomes a constituent part of the alveolar walls of the lung itself.

The alveolar passages open into spaces, called the "infundibula," in the sides of which are the openings into the alveoli of the lung, the ultimate destination of the inspired air. Here and there

HIG. 155.

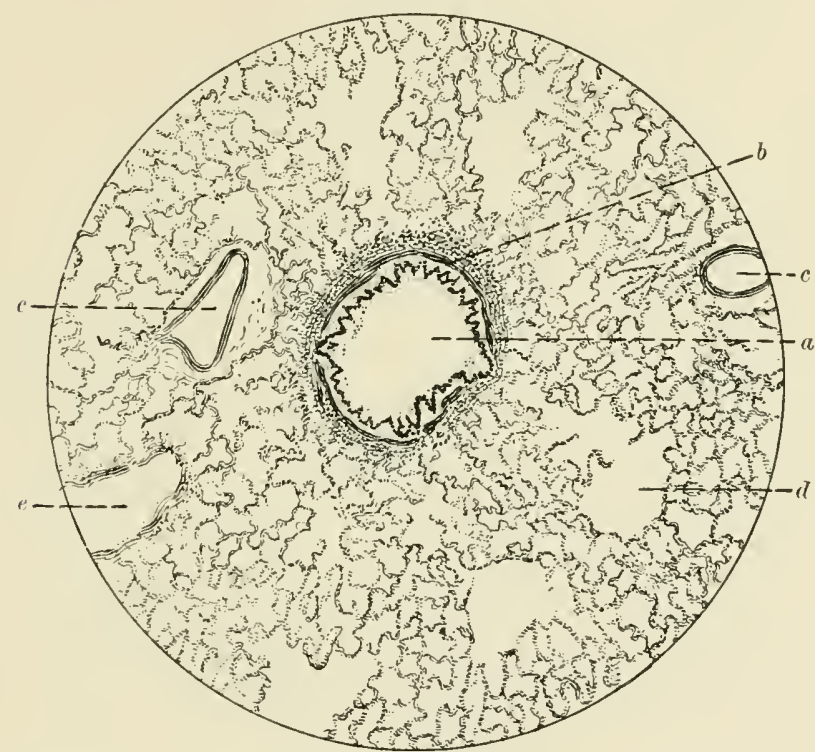

Section of lung of the dog, showing a transverse scetion of a bronchiole: $a$, bronchiole ( $a$ little mucus covers the epithelial lining); $b$, muscular layer of the mucous membrane; $c$, $c$, radicles of the pulmonary vein; $d$, alveolar passage, just at its division to form infundibula. An infundibulum extends from this passage toward the bronchiole. The wall of the alveolar passage at this point is similar in structure to that of the pulmonary alveoli. e, alveclar passage in oblique section. This passage is cut at a point further from its opening into the infundibula, and has a somewhat thicker wall than $d$. The rest of the section is made up of infundibula (the larger spaces) and pulmonary alveoli.

stray alveoli open directly into the alveolar passage- (Figs. 155, 156, and 157 ).

4. The pulmonary alveoli and the smaller air-passages are so arranged that there are no vaeant spaces; and neighboring alveoli, whether they belong to a group of infundibula springing from the same alveolar passages or to separate groups, are so elosely sitnated that they have but one common wall dividing their cavities 
from each other. Notwithstanding this general compactness of arrangement, the lungs are divided by delicate septa of fibrons tissue into more or less well-defined lobules, corresponding to the smallest bronchi or the bronchioles.

The alveolar walls are made up of a delicate, loose areolar tissue, containing numerous elastie fibres and supporting the abundant capillary plexus in which the blood suffer's the gaseous exchanges with the air that constitute the function of respiration (Fig. 158).

Fig. 156.

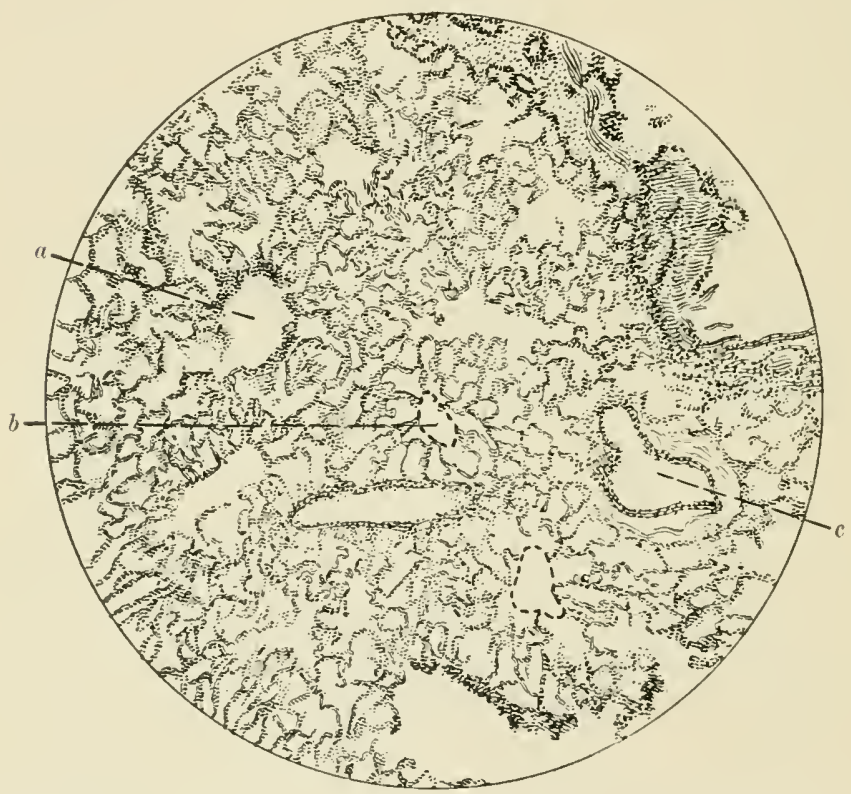

Section of lung of the dog: $a$, alveolar passage opening into an infundibulum and also into a solitary alveolus; $b$, cross-section of an infundibulum. The dotted line indicates the limits of the infundibular space. Opening into it are a number of alveoli. Were the dotted line removed, the infundibular cross-section and the al veoli around it would form a stellate space in the section. $r$, junction of two radicles of the pulmonary rein. At the top of the section, to the right, is an nblique section of a bronchiole.

Covering the two surfices of the alvenlar wall is a layer of very thin cellular plates (parement-epithelium, see Fig. 30), among which are scattered a few rells resembling those lining the alveolar passages. This cellular investment is eontinuous with the lining of the infundibnlum, which is of sinilar character, and thence with the epithelinm covering the inner surface of the alveolar passage. It is to be regarded as a special modification of epithelium, fitting it for usefulness in this situlation. 
The lung receives blood from two sources: 1, venous blood, through the pulmonary artery, which is oxygenated in the walls of the alvcoli; 2 , arterial blood, through the bronchial arteries. This arterial blood serves for the nourishment of the tissues of the lung, and is distributed to the bronchi, interlobular connective tissue, lymph-glands, and walls of the vessels. Part of this blood returns through the pulmonary veins; the rest through the bronchial veins.

FIG. $15 \%$.

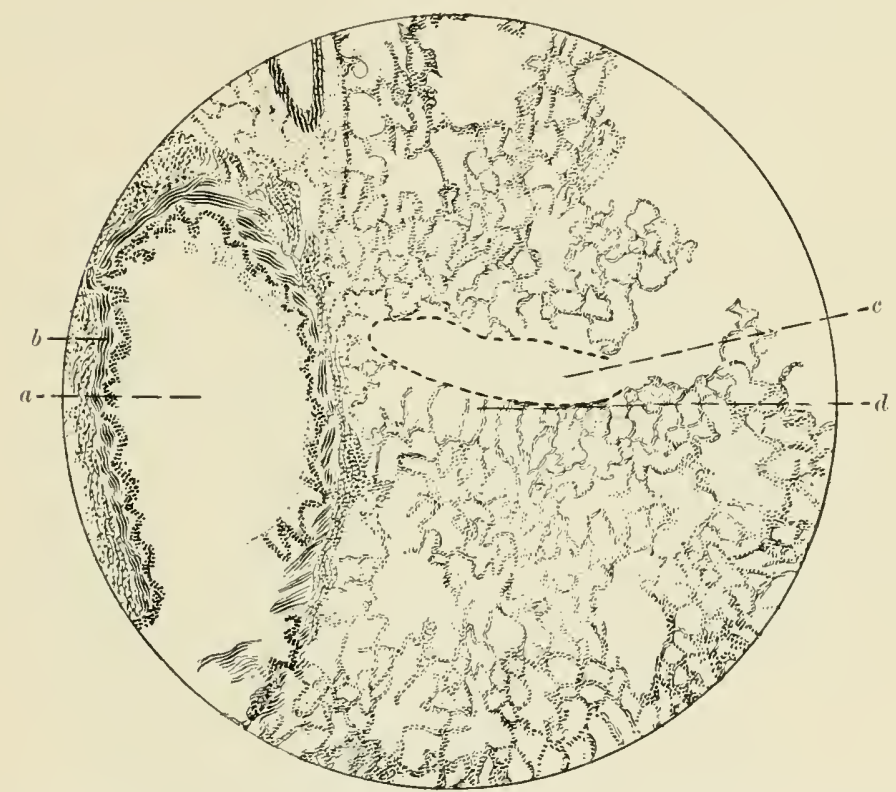

Section of lung of the $\operatorname{dog}: a$, oblique section of a bronchiole; $b$, its museular coat ; $c$, longitudinal section of an infundibulum, communicating to the right with an alveolar passage (the wall of the latter is torn further to the right); $d$, one of the alveoli opening into $c$.

The lymplaties arise in the walls of the alveoli and bronchi and pass to the bronchial lymph-glands.

The nerves supplying the lung may be traced along the bronchi, where they occasionally eomnect with groups of ganglion-cells, and along the vessels. They are of both the medullated and the nonmedullated varieties.

The surface of the lung is covered with serons membrane, a portion of the pleura.

Little need be said about the functional activity of the lung. The cilia, belonging to the columnar epithelium lining nearly the 
whole of the air-passages, possess a motion that urges particles lodging in the muens covering them toward the larynx, whence they are either coughed out or are swallowed. Such solid particles as pass beyond the regions guarded by ciliated epithelium are tilien 11p by lencocytes, which frequently migrate into the alveoli and the air-passages, and are conveyed by them into the lymphatic ressels or glands. Because of this the lymphatics and bronchial lymphatic nodes are apt to be blackened by the deposition of earbon, except in young individuals. The flow of air into the lung is the result of atmospheric pressure, which tends to fill the thoracic eavity when the

FIG. 158.

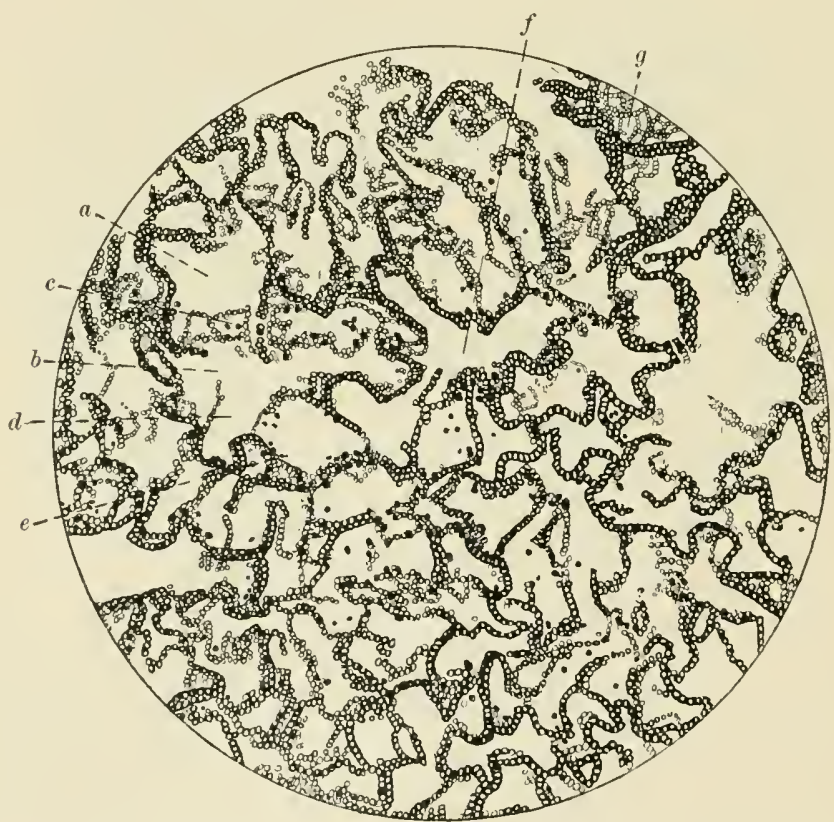

Section of the lung of a dog, killed by ether-narcosis. The lung was lyypermic at the time of death, and the capillaries retain their blood in the section. $a$, alveolus in eross-seftion, communicating with the infundibulum, $b$. A portion of the wall of the alveolus is seen, in surfaee-view, at $c$. $d, e$, other alveoli opening into the same infundibulum: $f$. ('ross-section of an infundibulum with alveoli opening into it: $g$, surfice-aspect of an alveolar wall, showing capillary plexus filled with red blood-corpuscles.

chest is expanded throngh the action of the museles of respiration. The air is expelled from the lungs when those museles relax, partly beeanse of the pressure exerted by the thoracie walle, but ehiefly becanse of the contraction of the elastic fibres in the alveolar walls. 
Becanse of their presence the lungs retract when the chest is opened.

When sections of the lung are examined under the microscope it is difficult, at first, to identify the different portions, which are cut in all directions. 'The smaller bronchi may be recognized by the presenee of cartilage in their walls. The bronchioles possess no cartilage, but are surrounded by a band of smooth mus. cular tissue, the muscularis mucose. This becomes thinner, then incomplete, and finally disappears as the infundibula are reached. The infundibulum, it will be remembered, is the space into which the alreoli open. When seen in section it will appear as a round, oval, or elongated space, according to the direction in which it has been cut, bounded by scallops, each of which is the eavity of an alveolus. In every section there will be many alveoli which have been so cut that their openings into the infumdibulum will not be included in the section. These alveoli have a continuous wall surrounding their carities. Still other alreoli will have been ent in such a way that a portion of their walls will lie in the plane of the section and parallel to it, so that the flat surface of the alveolar wall will be risible, surrounded by an oblique or cross-section, where the wall meets the surface of the section. Those alveolar walls which have been eut perpendicular to their surfaces will appear thinner than those which have been cut obliquely. With these considerations in his mind, the student can have little difficulty in identifying the different portions of the section (see Figs. 155-158). 


\section{CHAPTER XIV.}

THE SPLEEN.

Nearly the whole surface of the spleen is invested with a covcring of peritoneum similar to that which partially covers the liver. Beneath this is the true eapsule of the spleen, which completely surrounds it. 'This capsule is eomposed of dense fibrous tissue, containing a large number of clastic fibres and a few of smooth muscular tissue. From its inner surface bands of the same tissue, called the "trabeculie," penetrate into the substance of the organ, where they branch, and the branches join each other to form a coarse meshwork occupied ly the parenchyma of the organ, the "pulp."

The bloodvessels of the spleen enter at the hilum and pass into the large trabcenla, which start from the capsule at that point and enclose the vessels until they divide into small branches. The vescels then leave the trabecula and penctrate the pulp, where they break up into eapillaries, which do not anastomose with each other. There is some doubt as to the way in which these capillaries end. Aceording to one view, they mite to form the venoms radieles, so that the blood is confined within ressels throughout its course in the spleen. Another view is that the walls of the capillaries become incomplete, clefts appearing between thcir endothelial cells, which finally change their form and become similar to those of the reticulum of the pulp. The veins, according to this view, arise in a manner similar to the endings of the arteries. The result of this would be that the blow is discharged, from the capillary terminations of the arteries, directly into the meshes of the pulp, after which it is taken up by the capillany orimins of the veins (Figs. 159 :ml 160). Studies of the vaseular structures in the spleen made with the aid of injections under valying conditions of pressure, in collapsed and in distended spleens and with different injection-materials, have led to a thirl view, which, if correct, would explain the divergent opinions just mentioned. The delieate reticulum which pervales the organ is elastic and forms a fine-meshed layer over the small vessels, suppert- 
ing the enclothelium of the eapillaries. This epithelinm is composed of more spindle-shaped cells than are nsmal in capillary vessels

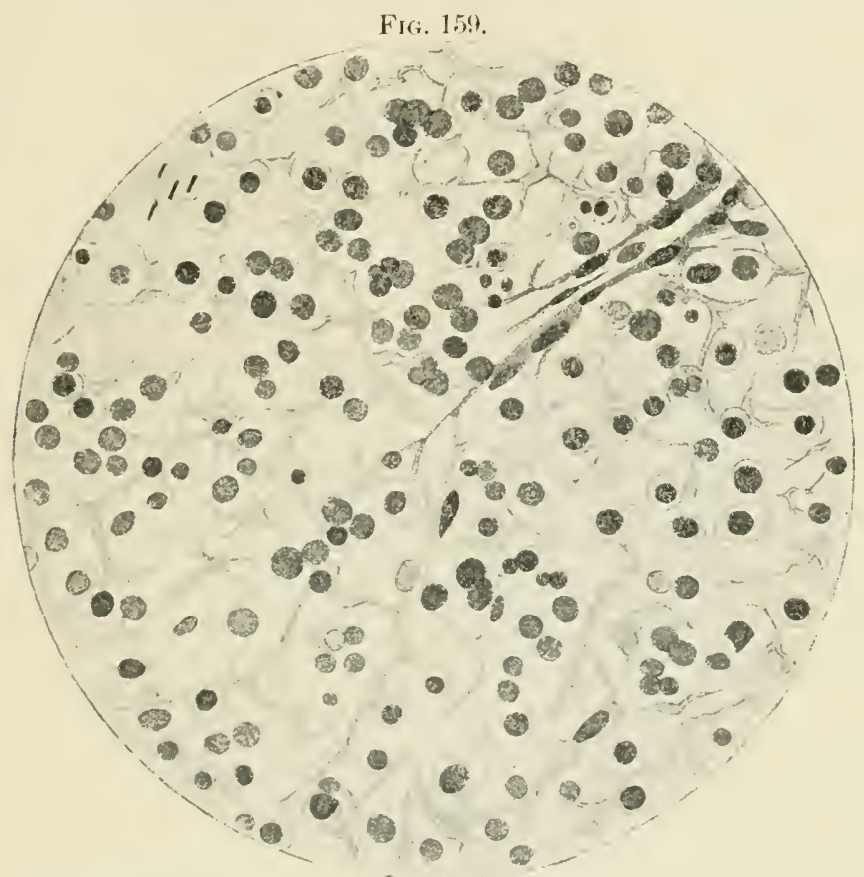

Section from the spleen of the cat. (Bannwarth.) Termination of an arterial capillary in the pulp.

and, when the vessels are di-tended, separate, leaving clefts between them. This separation may also be effected by distention of the Fici. 160.

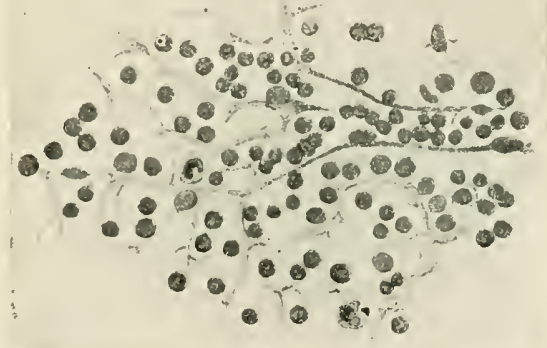

Section from the spleen of the eat. (Bannwarth.) Beginning of a capillary venous radicle. pulp-spaces which produces tension on the retienlar fibres, and this opens the clefts between the endothelia of the capillaries. When the 
eapillary blood-pressure is increated or the pulp distended or the tratbecule contract, these clefts apen; under other eiremstanees they are elosed and the circulating blond is confined to the vessels. The valsenlar connection between what may he called the arterial carpillaries and venous capillaries is a dilated capillary, or "anpulla," larger than other eapillaries, and it is in these ampulla that the endothelimm is composed of the narrowest spindle-shaped cells, so that the elefts between them would be most pronounced in this part of the vascular system of the organ. During life the spleen displays slow rhythmie contractions at intervals of about a minute, and from what has been said of its structure it will be obvinns that these contractions would favor the circulation of blood through its vessels and pulp. It appears, indeed, that these contractions are essential, for if the muscular tissnes be thrown out of function by severing the nerves, the circulation is so interfered with that the pulp becomes engorged with blood. No lymphatic vessels have been discovered in the splec'n.

The pulp consists of a fine reticulum of delicate fibres and cells, with branching and communicating processes, in the meshes of which there are red blook-corpuscles, leneocytes in greater number than normally present in the blood, and free amoboid cells con-iderably larger than leneoeytes, ealled the "splenie cells."

The adventitia of the arteries contains considerable lymphadenoid tis-ne, which after the exit of the vessels from the trabcenlix is expanded at intervals to form spherical bodies, alout $1 \mathrm{~mm}$. in diameter, ealled the "Malpighian bodies" or "corpucele." There are like little lymph-follieles, through which the artery takes its course. The reticulum in these Malpighian corpuscles is scanty and ineonspicuons near their centres, so that the lymphoid cells it contains appear densely erowled ; but toward their peripheries the reticulum is more pronomeed and the cells a trifte more separated. At the surface of the Malpighian body its reticulum becomes contimuons with that of the pulp surromeling it (Fig. 161).

The relations between the spleen and the blood flowing through it appear to be very similar to those between the lymphatic glands and the lymph passing throngh them. It seems to act ats a species of filter, in which foreign particles or damaged red blood-corpuseles are arrested and destroved. In many infeetions diseases the splenie pulp is inereased in amount and highly eharged with granules of pigment that appear to be derived from the coloring-matter of the 
blood. Some observations sngerest the conelusion that the eause of splenie enlargenent is the destruction of red corpuseles (or possibly leueoeytes also), hamolysis, which is frequent and pronouneed in many infeetions diseases. This is notably the ease in malaria, in which the red eorpuseles are destroyed by the plasmorlinm oceasioning the disease. When baeteria gain access to the blood, they are apt to be especially abundant in the splenie pulp, and it is said that monkeys, which are normally immune aruinst relapsing fever, may aequire the disease if the spleen be removed before inoenlation

FIG. 161.

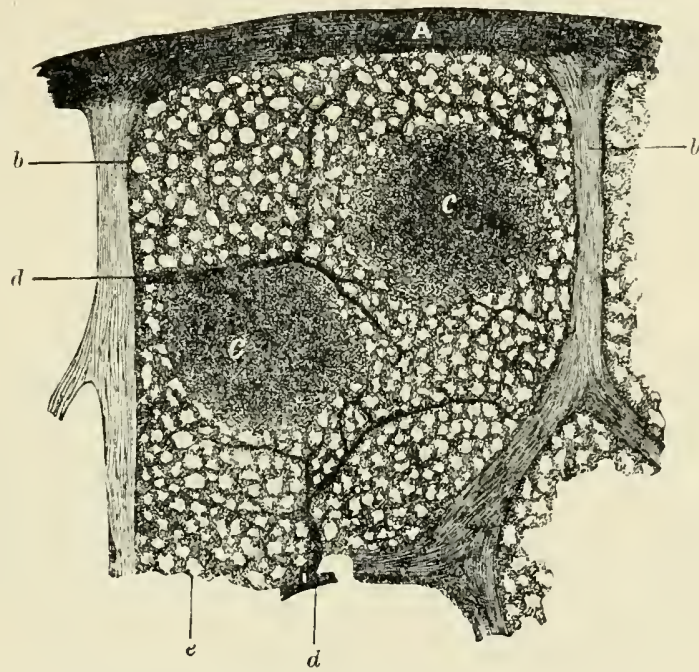

Section from human spleen. (Kölliker.) A, eapsıle; $b, b$, trabeculæ: $c, c$, Malpighian bodies (Iymph-follieles), traversed by arterial twigs. In the follicle to the left, part of the arterial twig is seen in longitudinal section; in that to the right, it appears in crosssection to the right of the eentre of the follicle. $d$, arterial branches; $e$, splenic pulp. The section is taken from an injected spleen.

with the spirillum which is the cause of that disease. Removal of the spleen leads to a diminution of the number of red enrpuscles in the peripheral circulation and to a still greater diminution in the hremoglobin of the blood, which lasts for many weeks, but eventually normal conditions are usually re-established, perhaps beeatuse of changes in the red marrow of the bones. These observations all tend to confirm the riew that the function of the spleen is to assist in maintaining the functional integrity of the blood. The lymphadenoid tissue within the spleen alon enriches the blood with an anditional number of leneocytes. 


\section{CHAPTER XV.}

THE DUC'TLESS GLANDS.

THE organs included in this group possess, at some stage of their development or in the adult, a structure analogous to that of the secreting glands. Those which retain this structure after complete development differ from the other glandular organs in being devoid of ducts, through which the materials elaborated by their parenchyma conld be discharged. Of these organs the thyroid is the most striking example. Other members of this group, notably the thymus, become greatly modified as development advances, and after a

FIG. 16:2.

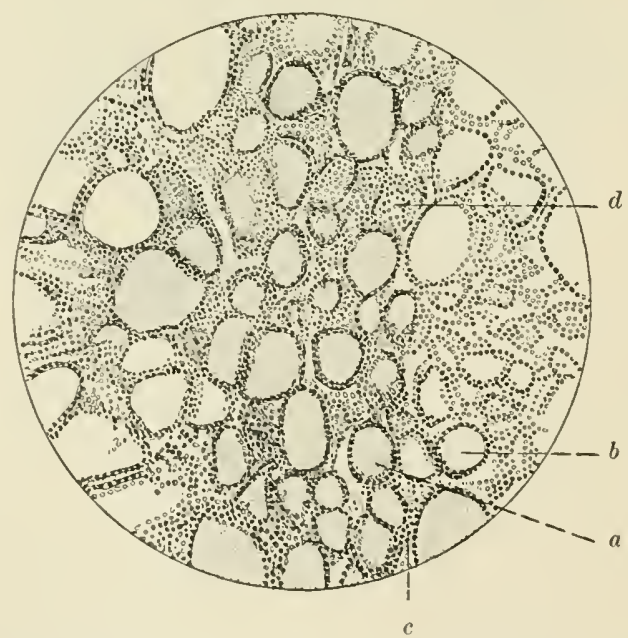

Section of human thyroid gland: $a$, alveolus filled with colloid; $b$, alveolus containing a serous fluid; $c$, interalveolar areolar tissue; $d$, tangential section of an alveolus, giving a superficial view of the epithelial cells.

while retain mere vestiges of their original epithelial eharacter; the ehief bulk of the organ being eomposed of lymphadenoid tissue.

The following organs and structures will be considered as belonging to the general group of duetles glands: the thyroid gland, the 1 1.8 
parathyroids, the adrenal bodies, the pituitary body, the thymus, and the earotid and coecrgeal bodies.

1. The Thyroid Gland (Fig. 162). - This eonsists of a number of alveoli or closed resicles, lined with cubieal epithelial cells arranged in a single layer upon the delicate, vascularized areolar tissue which forms their walls and separates the neighboring alveoli from each other. This fibrous tissue is more abundant in places, where it serves to divile the gland into a number of imperfectly defined lobes. At the periphery of the organ its connective tissne becomes continuous with a thin but morlerately dense fibrous capsule.

The individual alveoli differ both in respeet to their size and their contents. Many are more or less completely filled with a nearly homogeneons, glairy substance, of a slight yellowish tint, ealled "colloid," while others appear to be oceupied by a serous fluid.

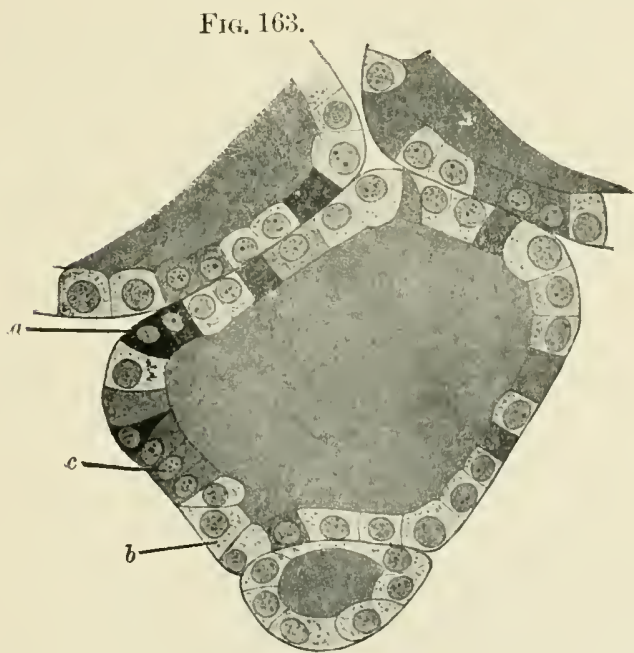

FIG. 164 .

Sertions of thyroid gland. (Schmid.)

Fig. 163.-From a $\log : a$, colloid or secreting cells; $b$, reserve cells (these differ only in their states of activity); $c$, cells containing less colloid than $a$.

Fig. 164.-From a cat: $a$, daughter-cells arising from the division of an epithelial cell.

The elaboration of this colloid material seems to be the function of the organ, though it may have other less obvious duties.

The cells lining the alveoli may be divided into two classes, which differ in appearance (Fig. 163): first, those engaged in the production of colloid, secreting cells; and, second, those in which no colloid is present, and which are regarded as reserve cells. The latter are capable of multiplication, thereby replacing such of 
the scereting cells as may be destroyed (Fig. 164). The colloid material is produced within the eytoplasm of the secreting cells,

FIG. 16.5.

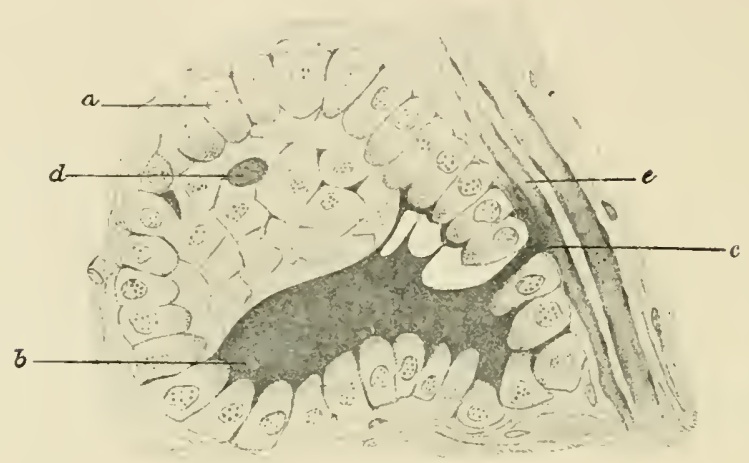

Section from thyroid of $\mathrm{log}$, illustrating the egress of colloid from the alveoli. (Bozzi.) $a$, epithelial cells lining the alveolns, seen in section. The internal ends of similar cells are seen in superficial aspect below. $b$, colloid within the alveolus; $c$, exit of colloid between two epithelial cells ; e, lymphatic vessel ; $d$, end of a colloid or secreting cell in the epithelial lining of the alveolus.

whence it is either expelled into the lumen of the alreolus, or the whole cell becones detached from the alveolar wall and suffers col-

FIG. 166.

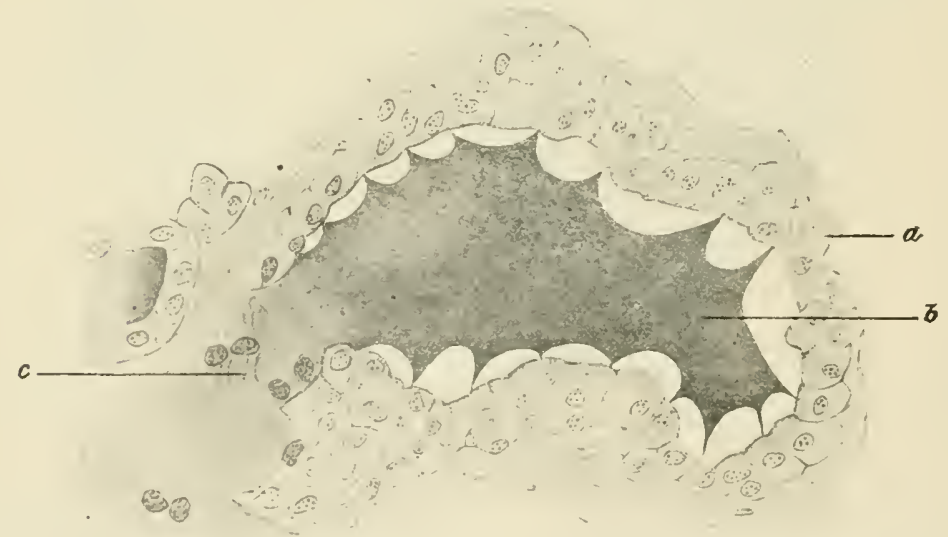

Scetion from thyroid of dog, illustrating the egress of colloid from the alveoli. (Bozzi.) $a$ epithelial lining of the alveolus; $b$, colloid; $c$, escape of colloid through a defect in the wall occasioned by the colloil metamorphosis of some of the epithelial cells, the nuclei of which are discernible within the culloid neas $c$.

loid degeneration, with destruction of the nuclens, within the alveolar cavity. 
The colloid material subsequently finds its way into the gencral (ireulation, either by passing between the intact cells of the alveolus ( Fig. 165), or after a passige has been prepared for it through alterations in certain of those cells (Fig. 166). The colloid is then taken up by the lymphatics, through which it reaches the general cireulation. This is an example of internal secretion which presents mueh of interest. It is probable that a similar, but much less obvious, process takes place in some of the ordinary secreting glands of the body, certain elaborated materials being returned to the circulation by the cells of the gland, while others are ntilized for their nourishment and for the elaboration of the more obvious secretion.

That the secretion of the thyroinl grland is of importance to the general organism is shown by the effects of disease or removal of the gland upon the general nutrition. Total extirpation of the thyroid, together with the parathyroids, nceasions the death of an animal within a few days, after symptoms of grave disturbances in the central nervous system, among which are tetanic convulsions. A partial removal of the gland, or its removal without that of the parathyroils, causes profound disturbances of nutrition, grouped under the title " cachexia strumipriva." 'The animal becomes weak, drowsy, and emaciated; the skin dry and scaly, with a loosening of the hairs. In young animals the growth is retarded, especially the development of the bones, through degenerative changes in the epiphysial cartilages. In these, the intercellular substance becomes swollen and disintegrated ; the cells atrophied or destroyed. Marked changes, designated as myxedema, also appear in the subeutaneous tissue, which is converted into a species of mucoid tissue, probably as the result of an altered metabolism within the pre-existent cells of the tissue. The functional activity of the kidney is modified; after a while, albuminuria results. Exactly similar disturbances have been observed in people suffering from discase of the thyroid gland.

The forgoing facts are eited here in order to emplasize by a striking example the statement previonsly made, that the organs of the body are mutually dependent upon each other.

Experimentation and clinical study lave further shown that the symptoms of myxcedema may be moderated or perhaps entirely arrested by feeding with thyroid extracts, or still more markedly by injecting extracts from thyroid glands beneath the skin, where they would speedily pass into the lymphaties and thence into the general circulation. 
Chemical examination hats revealed the presence of a substance called "thyroiodin" in the alveoli of the thyroid gland. This is a proteid containing a large amount of jodine. Its production by the thyroid gland may be inereased by feeding with substances containing considerable iodine or by administering iodide of potassium. Injections of thyroiodin serve to mitigate the effects of thyroidectomy, very much as do injections of thyroid extracts. It is by no means clear, however, that the thyroiodin is the only substance elaborated by the thyroid gland which may be of use to the tissues

FIG. $16:$.

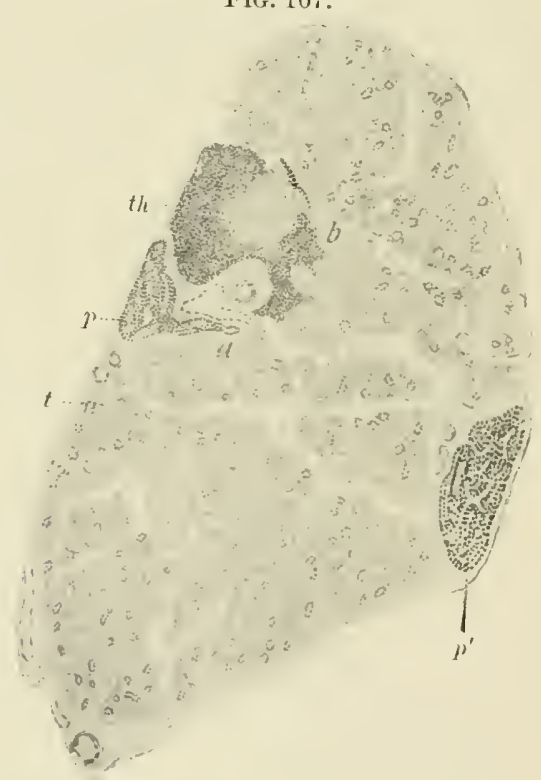

Section of the thyroid gland of a kitten two months old. (Kohn.) Showing the positions of the outer and inner parathyroid bodies and a thymus follicle: $t$, thyroid gland; $p$, inner parathyroid: $p^{\prime}$, outer parathyroil: th, thymus follicle; $a$, portion of the section showing the intimate relations between the thyroid and the inner parathyroid; $b$. portion demonstrating a similar intimate relation between the thyroid and the tissues of the thymus follicle.

of other organs, or that the thyroid may not also remove injurious substances from the cirenlation and thus indirectly benefit other structures in the body.'

${ }^{1}$ Attention is also called to the possibility that an excessive or morbid thyroid secretion may cause symptoms of disease attributable to disturbances in the functions of other organs, and may also occasion disturbances in nutrition. 
The bloodvessels of the thyroid are abundant, and form a rich plexus in the areolar tissue between the alveoli. The lymphaties are also abundant and large, forming a network of rather large vessels in the same sitnation. The nerves accompany the vessels, are destitute of ganglia, and have been traced to the bases of the epithelial cells, whenee they may aceasionally send minute terminal twigs with enlarged ends between the epithelial cells.

2. The Parathyroids (Fig:. 167, 168, 169).-These are two bodies

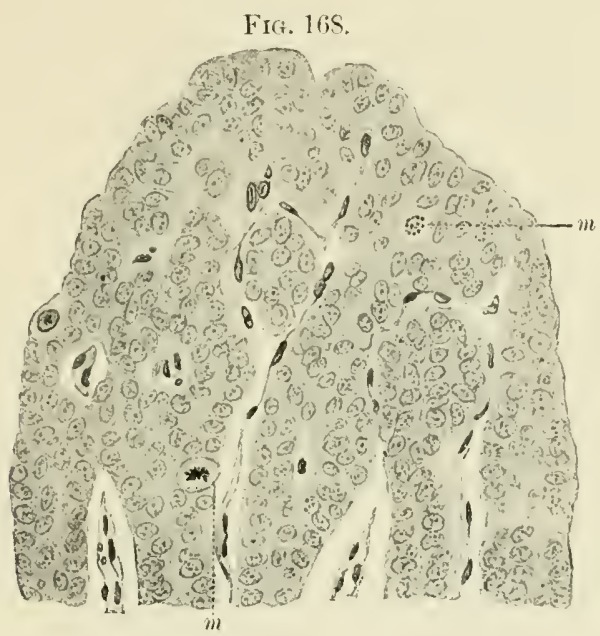

Section of a portion of the external parathyroid of a kitten two months old. (Kohn.) Showing the columns of epithelial cells separated by a delicate, vascular areolar tissue. The nuclei between the columns of epithelimm belong chietly to capillary bloodvessels. $m$, $m$, nuclei exhibiting karyokinetic figures.

of identical structure, whieh are developed in conjunction with the thyroid gland; but, while the latter progresses in its development until it attains the structure already describerl, the parathyroids retain a structure similar to that of the embryonic thyroid. They are composed of solid columns of epithelial eells, which anastomnse with each other, but are elecwhere separated hy a small amount of vasenlar areolar tissne. They are enclosed in a very thin eapsule of areolar tissue, but are in very close relation to the neighboring tissues of the thyroid gland (Figs. 167 and 169), and frequently also with isolated follicles of thymus tissue.

Different observers vary in their opinions respecting the parathyroids. Some regard them as reserve thyroid tissue, remaining dormant while the thyroid is functionally competent, but developing 
into thyroid tissue when the gland furnishes an insuffieient supply of secretion. Other obervers deny this and regard the parathyroids as embryonic rudiments, nearly, if not quite, devoid of function. It is certain that in some eases of thyroidectomy the parathyroids become enlarged, and that the cachexia strumipriva is not certain to develop after the removal of the thyroid gland unless the parathy-

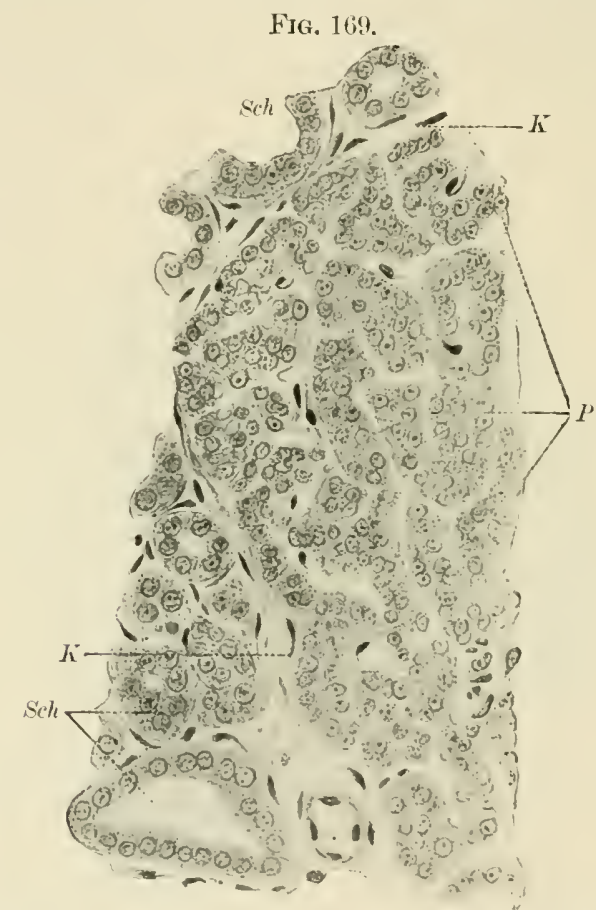

Section of the inner paratlyroid of a kitten two months old. (Kohn.) Showing its close connection with the tissues of the thyroid gland: $S c h$, alveoli of the thyroid; $P$, epithelial columns of the parathyroid; $\boldsymbol{h}$, capsule separating the two.

roids are also removed. Histological studies of the parathyroids in such cares have, however, failed to reveal a tendeney on their part to develop into true thyroid tissne. Their relations to the thyroid, therefore, still remain undetermined.

In some animals-e.g., the cat-there are four parathyroid bodies, two associated with each lobe of the thyroid.

3. The Adrenal Bodies (Fig. 170).-The adrenal borlies, or suprarenal capsules, posiess a fibrons eapsule, which is more areolar externally, where it frequently merges into the perinephric fat, 
and denser intemally, where it is reinforeed in some animals by smooth muscular fibres. From this capsule septa of areolar tissue penetrate into the substance of the organ and constitute its interstitial tissue. The parenchyma of the organ consists of columms of epithelial cells, which are differently arranged and have a somewhat different appearance in different parts. As the result of these differences the organ has been divided into a cortical and a medullary portion.

In the cortical portion the cells are arranged in solid columns having their long axes perpendicular to the surfice of the organ. Towad the capsule these columns lose their parallel arrangement and appear in vertical sections as islets of cells surrounded by areolan tissue, the "zona glomerulosa." In the deep portion of the cortex the cellular columns form a meshwork and completely lose their fascicular arrangement. This region is called the "zona reticularis." The epithelial cells in the cortical portion are polyhedral, and are frequently infiltrated

FIG. 170 .

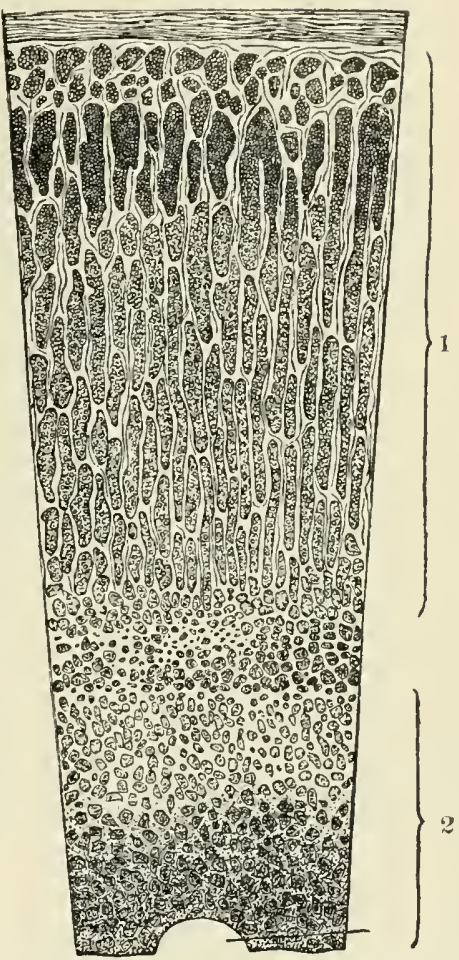

Vertical section of human adrenal body. (Elverth.) 1, cortex; 2, mednlla; $a$, capsule; $b$, zona glomerulosa; $c$, zona fasciculata; $d$, zona reticularis; $e$, groups of medullary cells; $f$, partial section of a large vein. with numerous globules of oil or fat, which give that part of the organ a yellow color.

In the nedulla the interstitial tissue of the organ encloses groups of epithelial cells, which differ from those of the cortex in being free from fat. They are also larger than those cortical cells which contain no fat (Fig. 171).

The arteries of the adrenal bodies enter as numerous small twigs at the surface of the organ and divide into capillaries within its fibrous septa. These open into a venous plexus in the medulla, which communicates with a single vein leaving the organ.

The nervous supply of the adrenal bodies is very abundant. The 
FIG. 171

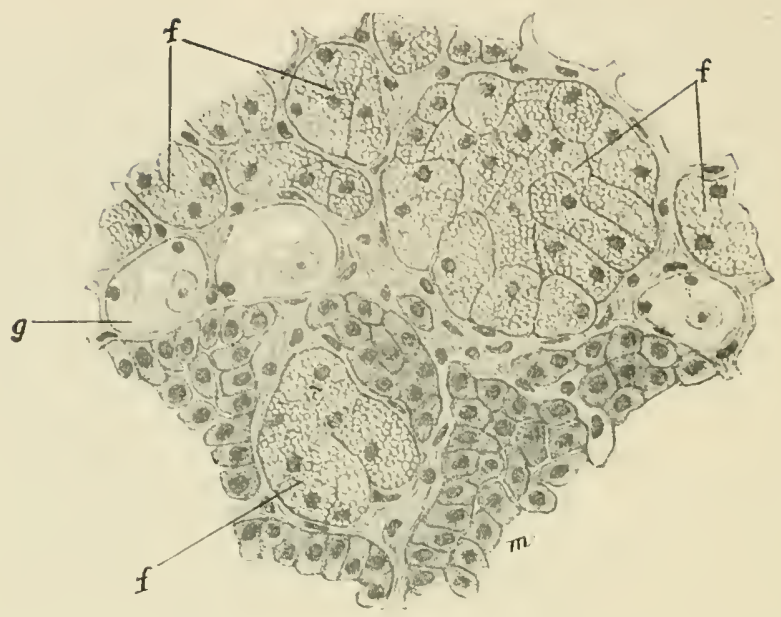

Section through the boundary between cortex and medulla in the adrenal body of the horse.

(Dostoiewsky.) $f, f, f$, cells of the cortex, infittrated with fat-globules; $g$, ganglion-cells ; $m$, epithelial cells of the medulla.

nerve-fibres are chicfly of the medullaterl variety, and their bundles contain numerons ganglia before entering the organ. Here the fibres ramify abundantly in the cortex, whence they penetrate into

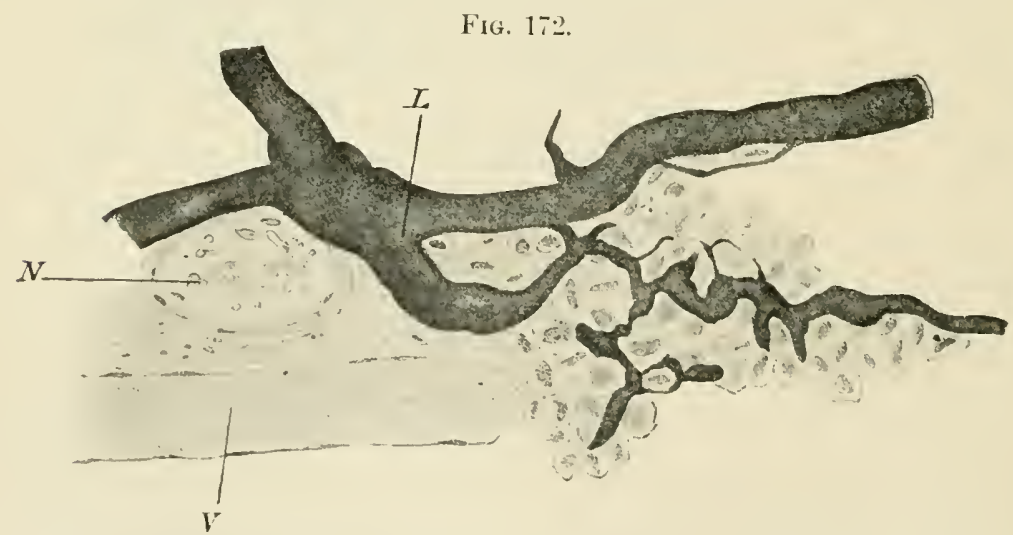

Injected lymphaties in an adrenal body of the ox. (Stilling.) $L$, injection-mass within the lymphatic vessels; $\mathcal{N}$, cross-section of a nerve: $r$, longitudinal section of a vein. lymphatic radicles are seen among the epithelial cells (cortical variety free from fat) to the right of the figure.

the merlulla. At the junction of the medulla and eortex the nerve-fibres are connected with g:mglion-cells. The nerve-termi- 
nations are distributed to the walls of the vessels and penetrate between the epithelial cells of the parenchyma.

As in the ease of the thyroid gland, the relations of the epithelial cells of the adrenal berlies to the lymphaties appear of special interest. The lymphatic vessels are abundant and large, and aceompany the bloodvessels lying in the areolar tissue of the septa. Here they come into close relations with the columns of epithelial cells, and, at least in the cortex, send minnte terminal branches into those eolumns, where they end among the epithelial cells (Fig. 172). This arrangement of the lymphaties appears to point to the elaboration of an internal secretion as the function of the adrenal bodies. Small masses of lymphadenoid tissne are occasionally observed in the eortical portion of the adrenal body.

4. The Pituitary Body.-The pituitary body (hypophysis cerebri) is divisible into two portions, which differ both in their structure and in their cmbryonic origins. 'The posterior, or nervous, lobe is derived from a prolongation of the third cerebral ventricle. The anterior, or glandular, lobe develops from a tubular prolongation, lined with epithelial cells, from the bneeal cavity of the embryo. This partially or completely invests the nervous portion of the body, but its ehief bulk is situated in front. The connection with the bnecal cavity is obliterated, and, in the further development of the detached portion, a number of anastomosing columns of epithelial cells are formed, which are separated from each other by septa of vascular areolar tissue. These septa become continuons at the periphery with a thin fibrons eapsule furnished by the pia mater.

The cells of the epithelial strands in the glandular lobe appear to be of two sorts, which, like those in the thyroid gland, probably represent different stages of functional activity. The darker sort of cell yields microchemical reactions resembling those of colloid; and little masses of colloid, presumably derived from those cells, are of not infrequent occurrence within or at the margins of the epithelial columns (Figs. 17:3 and 174).

The glandular lobe is riehly supplied with eapillary bloodvessels in intimate relations with the epithelinm, from which they often appear to be separated by only a thin basement-membrane, and the existence of this is donbtful in some situations (Fig. 175).

The above description shows that the structure of the hypophysis is similar to that of the other dnctless glands already considered. 
F1G. 173.

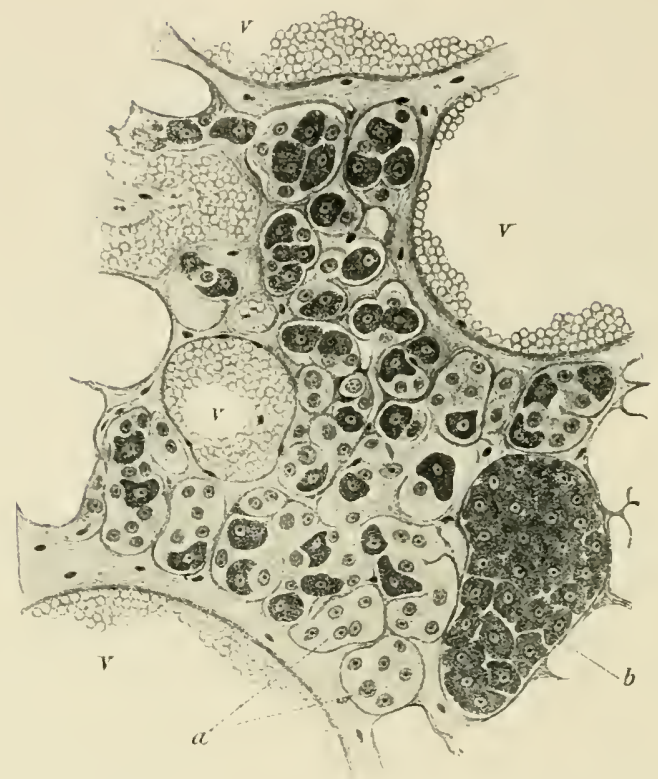

Section from the hypophysis of the ox. (Dostoiewsky.) $v$, veins; $\alpha$, alveoli or cell-columns, with pale, relatively clear cytoplasm; $b$, alreoli or columns of darker granular cells. other cell-groups contain both varieties of cell.

FIG. 17 .

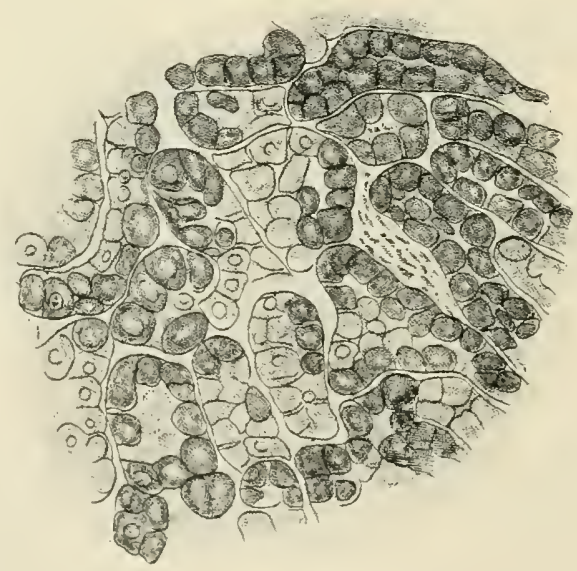

Section from the glandular lobe of the hypophysis: horse. (Lothringer.) Showing the darker cells at the periphery of the epithelial strands, and the clearer cells, for the most part, in their centres. 
Its function is still very obseure; but it appears, in cases of experimental thyroidectomy and in disease of the thyroid in the human subject, to enlarge when the function of the thyroid gland is abolished and to assume vicarionsly the duties of that organ. In how far this points to a normal similarity in function of the two organs must, at present, be left undetermined. In cases of enlargement of the pituitary body profound changes in nutrition, characterized chiefly by overgrowth, frequently take place in the bones of the skeleton (acromegaly).

The nervous supply of the anterior lobe consists of non-medulFI\%. 175 .

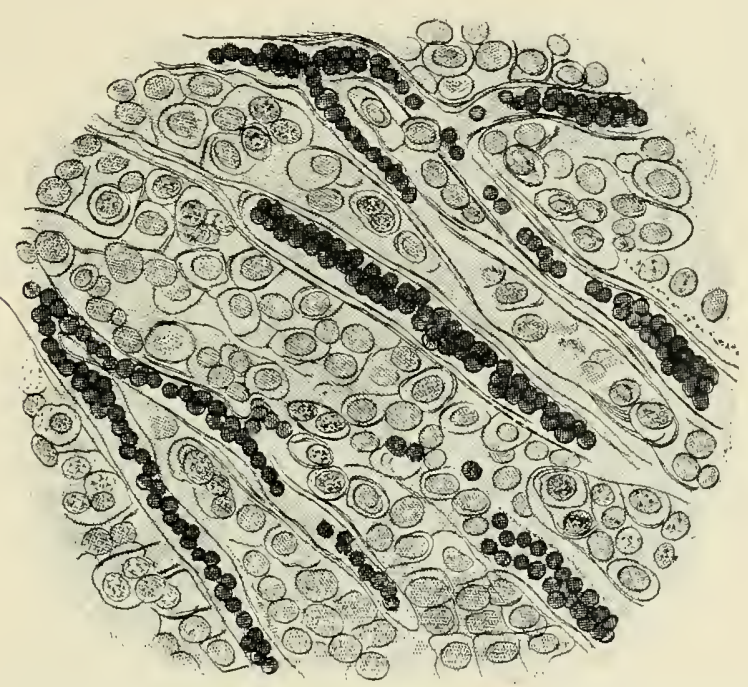

Scction from the glandular lobe of the hypophysis; child six months old. (Lothringer.) The close relations between the epithelial eells and the capillary bloodvessels, and the differences in the cells, are inlieated in this figure. The red blood-corpuscles within the capillaries have been stained dark.

lated fibres, lestitute of ganglion-cells, which ramify about the vessels and send some of their terminal twigs between the epithelial cells.

The posterior lobe consists of tissues resembling those of the central nervous system : ganglion-cells, non-medullated fibrils, and neuroglia-cells. Within its substance there are also peeuliar oval bodies surrounded by nervous terminations, to which sensory functions have been attributed, and small follicles, lined with cubical epithelium. 
5. The Thymus.-This organ reaches its fullest development at aboit the sceond year of life, after which retrograte changes, ending in the substitution of fibrons and andipose tissues for its proper strueture, take place. Its development begins as an ingrowth of epithelium from the branchial clefts. This epithelium forms a

FIG. 176.
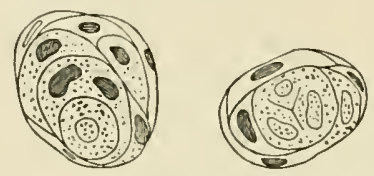

Two concentric corpuseles of Hassall, from the foetal thymus. (Klein.)

branching, solid column of cells surrounded by embryonic connective tissue, which develops into lymphadenoid tissue. In the meantime the epithelial strands are broken up and the whole organ becomes converted into a structure resembling a collection of lymphfollicles, but with this difference: that remnants of the epithelial strands remain in the centres of many of the follicles, where their

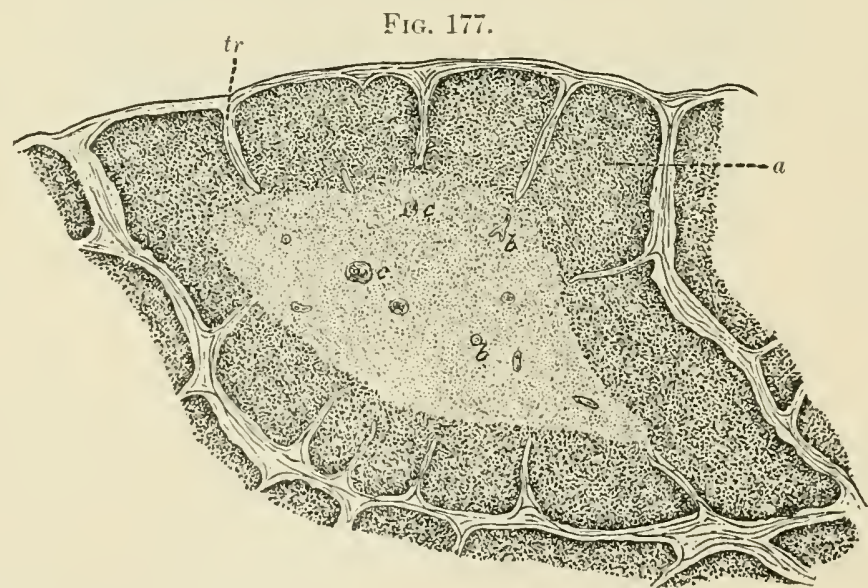

Lobule from the thymus of a chilu. (Nehaffer.) $t r$, trabeeula; $a$, nodule of denser lymphadenoid tissue at periphery (" cortex"); $b, b$, sections of vessels within the less dense lymphadenoid tissue in the centre ("medulla"); $c, c$, concentrie corpuscles of Hassall.

rells become flattened and imbrieated. These epithelial masses are known as the concentric corpunceles of Hassall (Fig. 176).

The thymus is enelosed in a fibrous capsule, which penetrates its sulstance, dividing it into lobes and lobules. Each of these lobules closely resembles a lymph-follicle, but it is donbtful whether lymph- 
sinuses, corresponding to those in the lymphatic nodes, are present in the thymus (Fig. 17t).

'The finction of the thymus is still a matter of doubt. It has been regarded as one of the sites in which red blood-corpuseles are formed, and also as a temporary lymphadenoid organ playing the part of the lymph-nodes until these have become fully developed in other parts of the body.

The thymus is connected with the thyroid by a strand of thymustissuc, and isolated thymus-lobules are foumd embedded in the elges of the thyroid, near the parathyroid body (see Fig. 167).

'The bloodressels ramify in the septa of the organ and send branches into the lymphoid follicles. The lymphatic ressels accompany the bloodvessels and surround the lobules, but do not appear

\section{FIG. 178.}

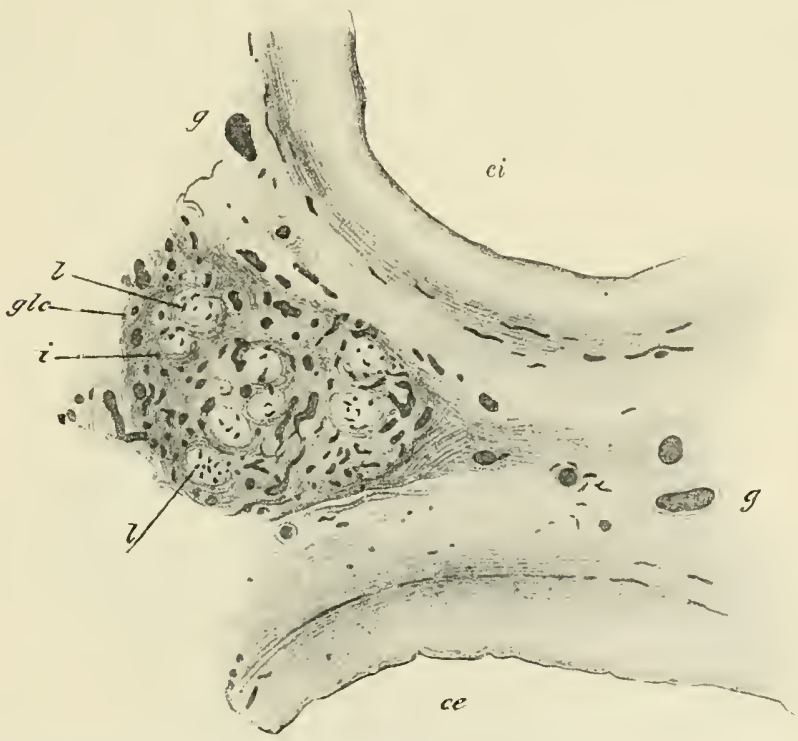

Section of the carotid gland and carntid arteries near their origin. (Marchand.) $c i$, internal rarotid; $c e$, external carotid; gle, carotid gland; $l, l$, greups of epithelial cells; $i$, fibrous tissue between the epithelial groups; $g$, bioodvessel. Numerous vessels are also seen within the gland.

to penetrate into the lymphadenoid tis-ue. 'The nerves are small and not numerous. 'They acenmpany the bloodvessels, but nervous terminations have not been traced as distributed to the lymphadenoid tissue.

The involution of the gland appears to be accomplished through 
Fis. 179.

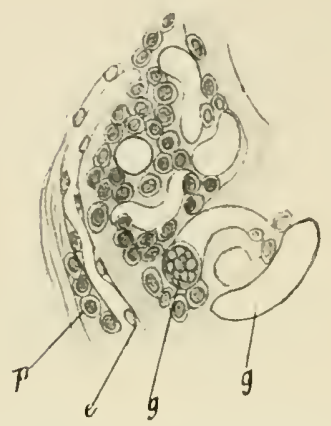

Portion of the same gland as Fig. 170, more highly magnified: $p$, epithelial cells; $g$, capillary bloodvessels; $e$, endothelium forming the capillary wall.

a proliferation of the fibrous tissue around the lobules, which encroaches upon the lymphadenoid tissue and gradually replaces it. This fibrous tissue subsequently becomes, in great measure, converted into adipose tissue. It appears as though the endothelium of the bloodvessels also proliferated, giving rise to masses of imbri-

Fis. 180 .

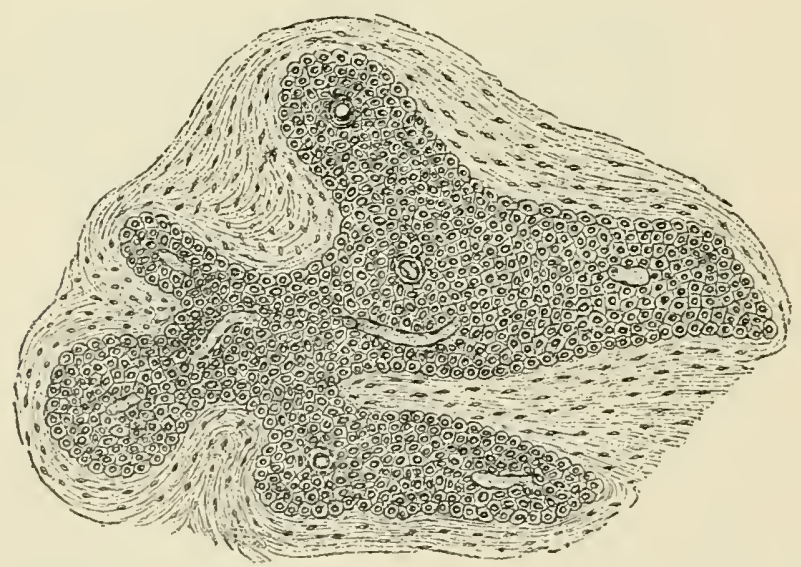

Section of the coceygeal gland. (Sertoli.) The group of cells, apparently of epithelial nature, is (raversed by small bloodressels and enclosed by fibrous tissue.

cated cells within the follicles and learling to an obliteration of the vascular lumen.

6. The Carotid Glands. - These consist of groups or islets of epithelial cells, surromded by fibrous ti-sue from which numerous capil- 
lary bloodvessels are distributed in close relation with the epithelial cells (Figs. 178 and 179). Their function is unknown.

7. The Coccygeal Gland.-This body is made up of groups and strands of cells, probably of epithelial nature, elosely applied to the walls of eapillary bloodvessels and surrounded by fibrous tissue. Its function and mode of origin are both unknown (Fig. 180). 


\section{CHAPTER XVI.}

\section{THE SKIN.}

The skin consists of a deeper, fibrous portion, the corinm, or true skin, and a superficial, epithelial layer, the epidermis. As a part of the latter, and developing from it, the skin contains two sorts of glands, the sebaceous and the sweat-glands, and two kinds of appendages, the hairs and nails.

The corium is composed of vascularized fibrous tissue, which is

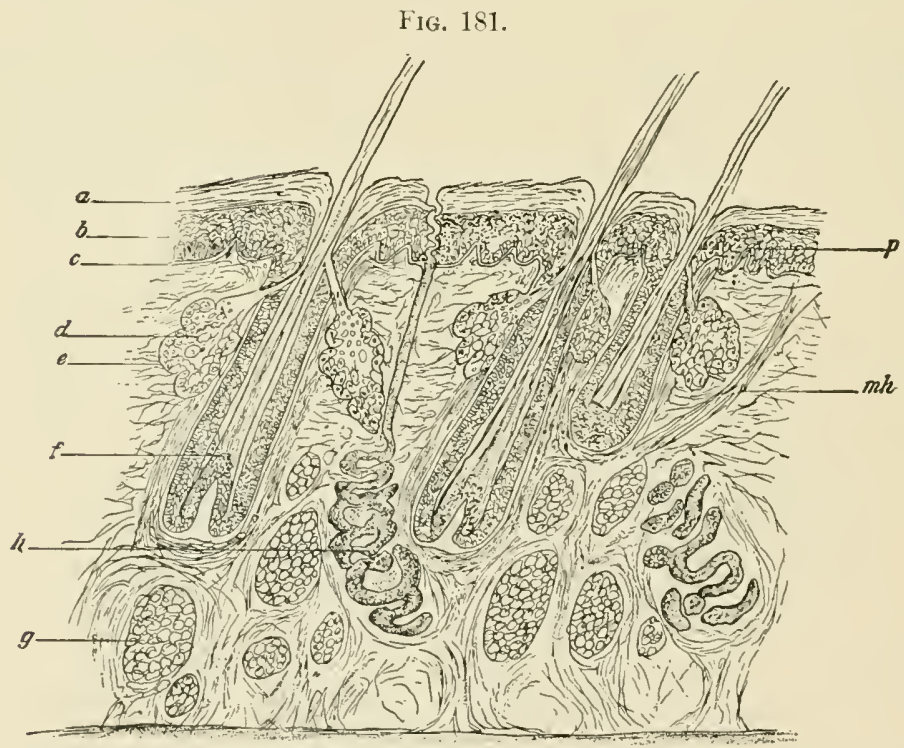

Section of skin perpendicular to the surface. (Arloing.) $a$, horny layer of the epidermis ;

$b$, rete mueosum; $c$, surface of the corium; $d$, sebaceous gland; $e$, areolar tissue of the corium; $f$, hair-shaft within the hair-folliele; $g$, lobule of adipose tissue in the subeutancous tissue: $h$, sweat-gland ; $m l$, arrector pili ; $p$, papilla of the corium extending into the rete mucosum. The lower limit of the corium is not marked by a plane parallel to that of the surface of the skin. The corium may be said to end where the fat of the subcutaneous tissue begins.

made up of bundles loosely arranger in its decper portions, where it becomes continnous with the subentaneons areolar tissne, and contains. 
a valiable amount of fat, but more compactly disposed in the superficial portions, where it comes in contact with the epidermis, into which it projeets in the form of papillae. Some of these papilla eontain loops of eapillary bloodressels, while others are oceupied in their centres by peenliar nerve-endings, called "tactile corpuscles." In some situations, notably upon the palms and soles, the papillat of the corium are arranged in rows. In most parts of the skin they are irregularly scattered over the surface of the corium (Fig. 181).

The epidermis (Fig. 182) is a layer of stratified epithelium in

\section{Fig. 182.}

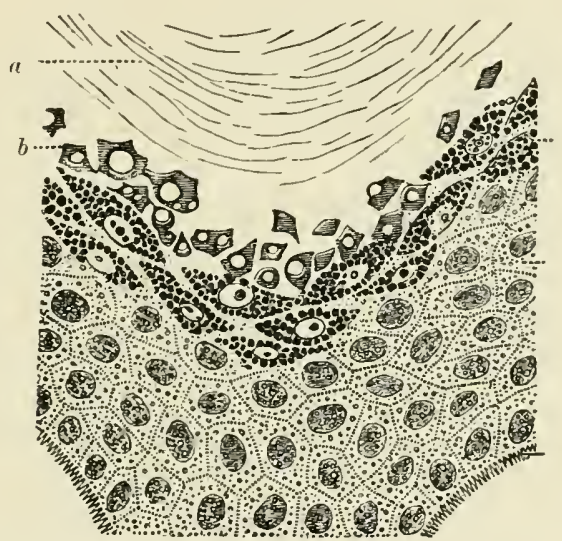

Vertical section of the epidermis of the finger. (Ranvier.) a, stratum corneum, or horny layer; $b$, stratum lucidum ; $c$, stratum granulosum ; $d$, rete mucosum ; $e$ " prickles" on the cells bordering on the corium, which is not represented.

which the cells multiply, where they are situated near the corium, and gradually suffer a conversion into horny scales as ther are pushed toward the surface, where they are eventually rlesquamated. The changes the cells undergo in their journey from the deeper layers of the epidermis to its surface cause variations in their appearances which have oceasioned a division of the epidermis into a number of more or less well-rlefined strata. The deepest stratum, where the cells multiply and grow, is called the "rete mueosum." It is eomposed of eells which gradually enlarge, beeoming rich in cytoplasm, and are eomnecter with each other by minute cytoplasmie "prickles," between which there is a space affording a chanuel for the circulation of mutrient fluids (Fig. 39). Above the rete mueosum the cells appear more granular, owing to the formation 
of a substance, called "eleidin," within the cytoplasm (Fig. 183). These cells form the "stratum gramulosum." The eleidin appears to be produced at the expense of the cytoplasm, the process being a form of degeneration, so that after a while the whole cell is converted into a homogeneons material in which the nncleus persists in a form deprived of ehromatin, and therefore insusceptible of staining. The presence of these cells gives rise to the formation of the "stratum lucidum" immediately above the stratum granulosum. Within this stratum the eleidin appears to pass into a closely related substance of a horny nature, keratin, and the cells become con-

Fig. 183.

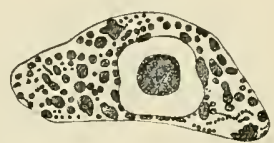

Cell from the stratum granulosum of the epidermis of the scalp. (Rabl.) The cytoplasm of the cell has been in great measure converted into granules of eleidin; the chromatin of the nucleus has retracted into a compact mass in the centre of the nuelear region, and is destined to disappear. This cell is from a sectiou made parallel to the surface of the epidermis, which accounts for its shape aud aplarent size.

verted into firmly compacted seales, which make up the most superficial or horny layer of the epidermis.

The sweat-glands are simple tubular glands, the deep ends of which are irregularly coiled to form a globular mass situated in the decper portion of the corium or at virious depths in the subcutaneons tissue. From these coils the exeretory duet passes through the corium to the epidermis, where it opens into a spiral channel between the epidermal cells, ending in an orifice at the surface of the skin.

The epithelial lining of the sweat-gland is a continuation of the stratum mucosum, from which it is derived, and consists of two or more layers of cubieal cells in the duct and of a single layer of more columnar cells in the deeper, seereting portion of the glind. In the duct these cells rest upon a homogeneous basement-membrane, but in the secreting portion there is a more or less complete layer of elongated cells, similar in appearance to those of smooth muscular tissne, which lie between the epithelial cells and the basement-memhrane (Fig. 184). It is doubtful whether these are really musclecells. The loops of the glandular coil are surrounded by fibrous tissue, which contains the bloodvessels supplied to the grland and serves to support it in its globular form. 
The sebaceous glands ean best be described in connection with the hairs and their follicles.

The bulbous attachment, or " root," of the hair, and the adjacent portion of its shaft, are contained in an invagination of the corium and epidermis, called the "hair-follicle" (Fig. 181,f). This is surrounded by fibrous tissue, forming its external coat, which may be imperfectly distinguished into an outer layer, containing relatively abundant longitudinal fibres, and an inner layer, in which encircling

FIG. 184.

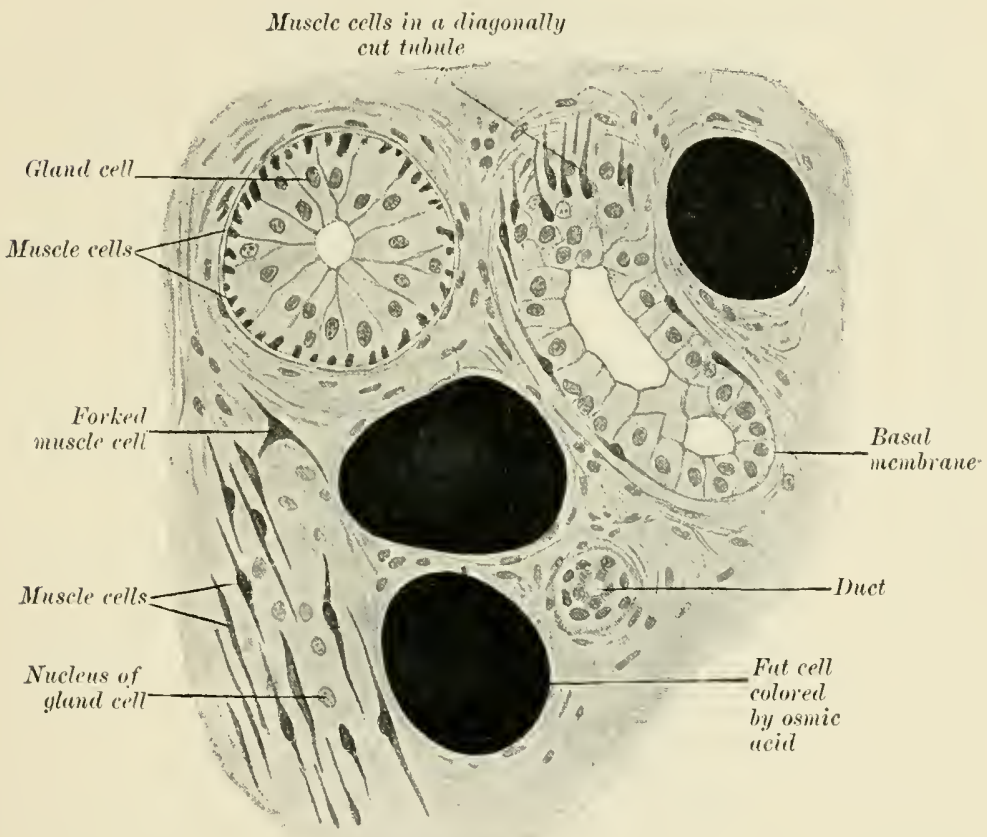

Some tubules of sweat-glands from the skin of a human finger. To the left of the two lower fat-cells are muscle-fibres and a few gland-cells belonging to a tangential section of a sweat-gland tubule. $(\times 350$. $)$

fibres predominate. At the bottom of the follicle this fibrous tissue becomes continuous with that of a vascularized papilla, similar to those existing on the surface of the corium, which projects into the root of the hair.

The fibrous sac constituting the outer part of the hair-follicle is lined with a continuation of the epidermis, lcaring a cylindrical eavity occupied by the hair. This laver of epithelium is reflected 
upon the surface of the papilla, where it forms the root of the hair,

Fiti. 185.

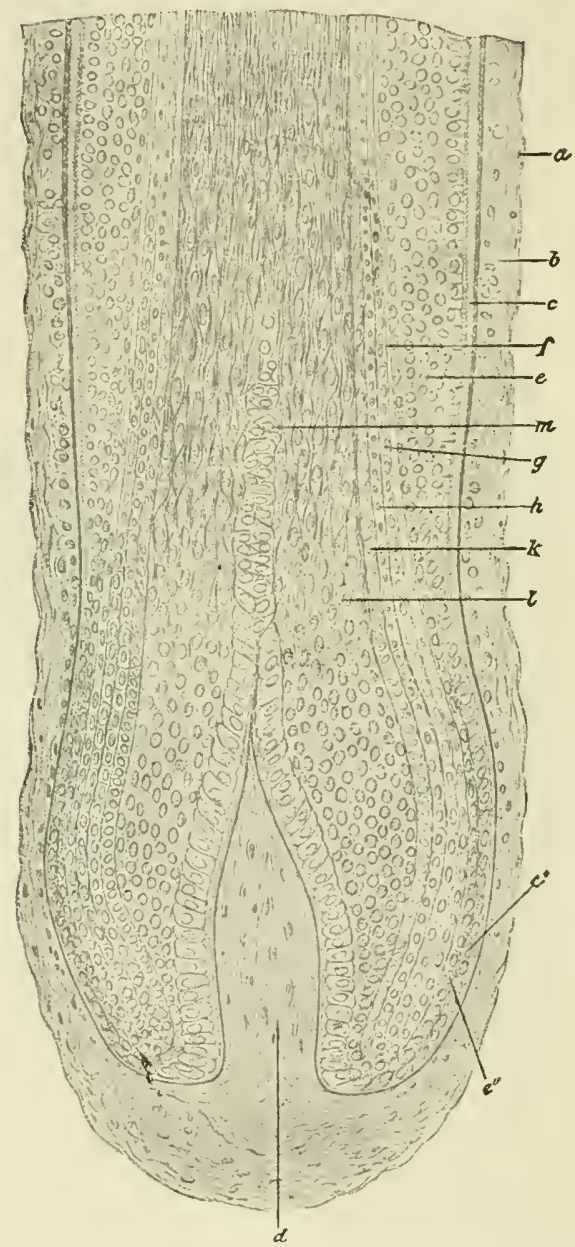

Hair-follicle from the human sealp. (Mertsching.) Longitudinal axial section through the fundus: $a, b$, longitudinal and encircling layers of the fibrous coat; $c$, hyaline layer, formed of an outer faintly fibrillated and an inner more homogeneous lamina; $d$. papilla; $e$, outer root-sheath, continuous with rete mucosum of epidermis ; $c^{\prime}$, its outer layer, continuous with deepest cells of rete and with columnar cells covering the papilla; $e^{\prime \prime}$, its inuer layer, continumus with the cortical cells of hair; $f$, IIenle's sheath; $g$, Huxley's layer; $h$, cuticle of root-sheatl $: k$, cuticle of hair; $l$, cortical cells of the hair; $m$, medulla.

and then passes into the shaft, which is marle up of cells, derived from those of the root, that have suffered keratoid degeneration.

The epithelium lining the folliele, as well as that which composes 
the hair, is not of uniform eharacter throughout, and has been divided into a number of layer's, to which different observers have given special names. The group of cells surrounding the papilla are the seat of the multiplication which results in the growth of the hair. Upon the surfice of the shaft these cells become transformed into thin scales, each of which overlaps that above it. This very thin layer is ealled the "cuticle" of the hair. Beneath the cuticle the cells are erowded together into fusiform or fibrous elements, which make "u the chief mass of the hair-shaft. In the centre of this mass there is sometimes a line of more loosely aggregated cells, forming the "medula" of the hair. When this is present the surrounding part of the shaft, between it and the cuticle, is known as the "eortex" (Figs. 185 and 186).

The sebaceous glands (Fig. 181, d) are saccilations in the corium near the hair-follicles, which are filled with epithelial cells. The cells at the periphery divide, and, as they increase in size, push

FIG. 186.

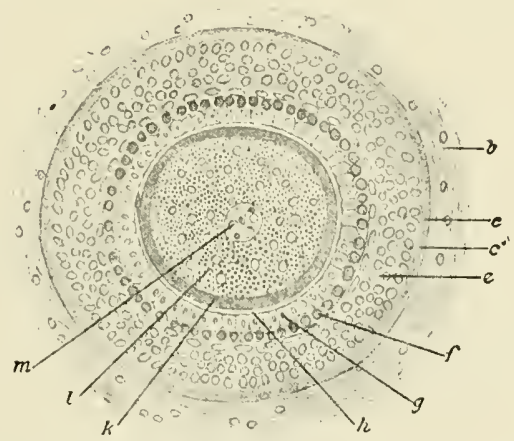

Hair-follicle from the human scalp. (Mertsching.) Cross-section from middle third of the follicle: $b$, longitudinal and encircling layers of the fibrous coat; $c$, hyaline layer, formed of an outer faintly fibrillated and an inner more homogeneous lamina, $c^{\prime} ; e$, outer root-sheath, continuous with rete mucosum of epidermis ; $f$. Henle's slieath; $g$, Huxley's layer; $h$, cuticle of root-sheath; $k$, cuticle of hair; $l$, cortical cells of the hair; $m$, medulla.

each other toward the centres of the sacs. Here they undergo at fatty degeneration, ending in destruction of the cells and the formation of an oily secretion, the sebum, which is discharged into the hair-follicle a short distance below its opening on the surface of the skin. The sebum is a lubricant for both the hair and the epidermis (Fig. 187).

The color of the epidermis and of the hair is due to a pigmenta- 


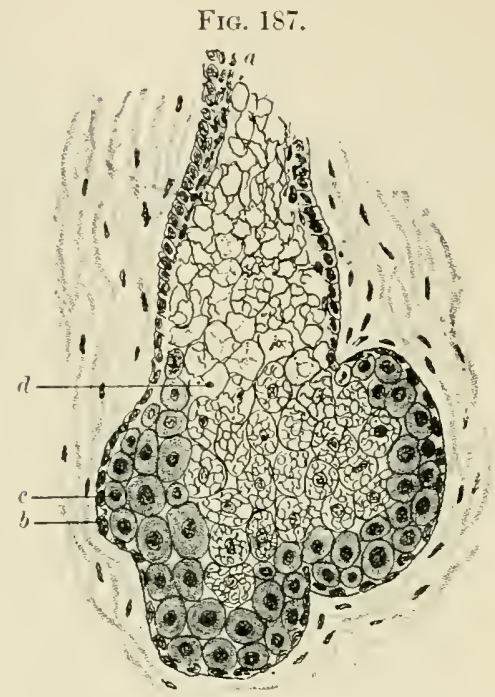

Sebaceous gland from the external auditory canal. (Benda and Guenther's Atlas.) a, epithelium eontinnous with that lining the hair-folliele; $b$, laver of proliferating epithelium lining the sae of the gland; $c$, enlarged cell beginning to undergo fatty metamorphosis of the cytoplasm; $d$, mass of sebum derived from a single epithelial eell.

tion of the cells in the deeper layers of the rete mucosum and those

FIG. 188.

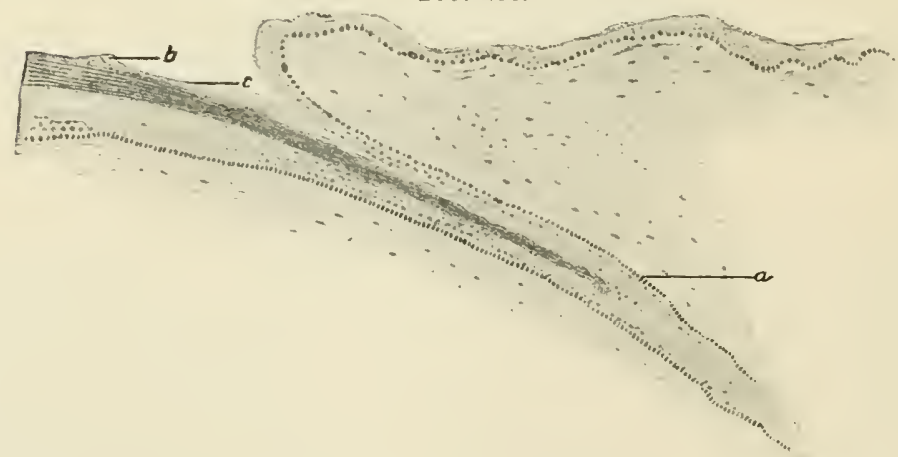

Section through the root of the nail of a sixth-months fetus. (Erust.) a, matrix of the nail formed by an invagination of the rete mucosum. Near the point indieated by the letter the epithelial cells bare begun to change into keratoid material. $b$, loosened seales of the surface of the nail; $c$, remains of the fretal cuticle which have not beeome keratoid. The letter $a$ and line proceeding from it both lie in the corium.

composing the hair. The whiteness of the hair which comes with years is due to little spaces which appear in unusual numbers 
between the cells of the cortex, and are filled with air, reflecting the light and masking the pigmentation of the cells.

The nails are especially thick and condensed masses of epithelial cells which have undergone keratoid degeneration and are closely compacted. They are produced at the root of the nail, and as they accumulate push the borly of the nail forward. They, therefore, correspond to the horny layer of the epidermis, which has become molified to form these special structures (Fig. 188).

The skin contains little museular bands, the arrectores pili (Fig. $181, m h)$, composed of smooth museular fibres, which are attached to the fibrous coat of the hair-follieles near their deep extremities and to the superficial layer of the corium on the sicle of the follicle toward which the hair leans. The action of these muscles is to cause the hair to assmme a more vertical position, and to raise it and the follicle, producing the effect known as "goose flesh." By their contraction they may also aid in the discharge of sebum, since their fibres often partially invest the sebaceous glands.

The functions of the skin have reference to its being the organ coming in contact with the external world. The epidermis protects the underlying tissues from mechanical and chemical injury and from desiccation. The keratin in its horny layer forms an impervious and tough investment of the body, which is highly resistant towarl chemical action and mechanical abrasion, and is constantly renewed from the layers that lie beneath it. It is kept in a pliable condition by the sebum discharged upon its surface and by the moisture proceeding from the sweat-glands, the "insensible perspiration." The skin also plays a prominent role in the regulation of the bolily temperature. When its vessels are contracted the amount of heat given off from the surface of the boly is reduced; when they are dilated, it is increased. A further loss of heat is oceasioned by an increased secretion of sweat, which bathes the surface of the skin and abstracts from the body the heat required to convert it into vapor. Under the influence- of sudden and marked cold the vessels of the skin become much contracted and the arrectores pili shorten, oceasioning the production of a roughness of the skin, goose-flesh, and probably also a discharge of sebum, which reluee the evaporation from the skin. At the same time a reflex rhythmical contraction and relaxation of the voluntary museles is brought about-shivering, which increases the 
liberation of stored energy within the body, and eanses it to appear as heat. In eonjunction with these functions the skin is also an organ of tactile and thermal sensation, functions which are not

FIf. 189.

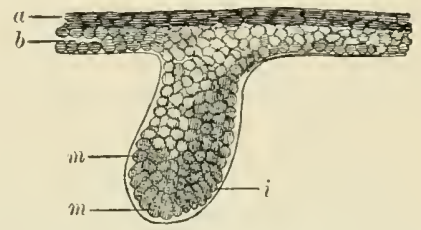

Hair-rudiment from an embryo of six weeks. (Kölliker.) $a$, horny layer of epidermis; $b$, Nalpighian layer, rete mueosum; $i$, limiting membrane; $m, m$, cells extending from the rete mueosum to fill the future hair-follicles. The elongated cells near the base of the sac are those from which hair is developed. The secreting glands of the body arise from some epithelial layer in a similar manner.

merely benefieial in themselves, but are useful auxiliaries in the furthering of the other functions exereised by the rkin. It is a common experience that the rensation of eold stimulates the desire

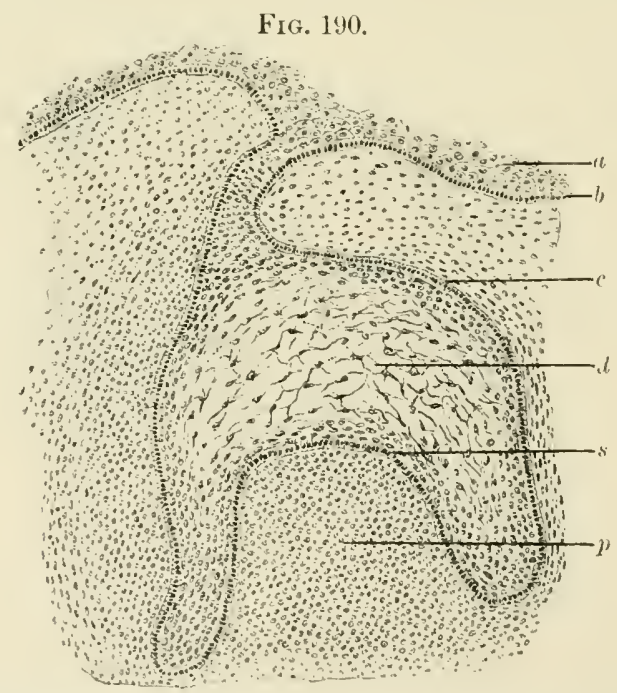

Scction of developing tooth. From embryo of sheep. (Böhm and Davidoff.) $a$, epithelium of the gum; $b$, its deepest layer; $c$, superficial eells of the enamel-pulp; $d$, cnamel-pulp formed of modified epithelial cells; $s$, cells of the enamel-pulp destined to produce the enamel (" adamantol,asts"); p, dental papilla.

for muscular exereise, of which the liberation of heat is a result. The sensation of pain often gives timely warning of exposure to an injury sufficiently great to overeome the nsmal protective powers of 
the cpicleruis. Thus we see that when the automatic action of the skin is inalequate for the performance of its functions it calls forth an anxiliary activity of other organs through the medium of the nervous system.

The hair-follicles are developed from the rete mucosum of the epidermis, and first appear as little masses of cells growing into the underlying connective tissues (Figr. 189). The sebaceous glands arise as offshoots from these ccllular masses.

FIG. 191.

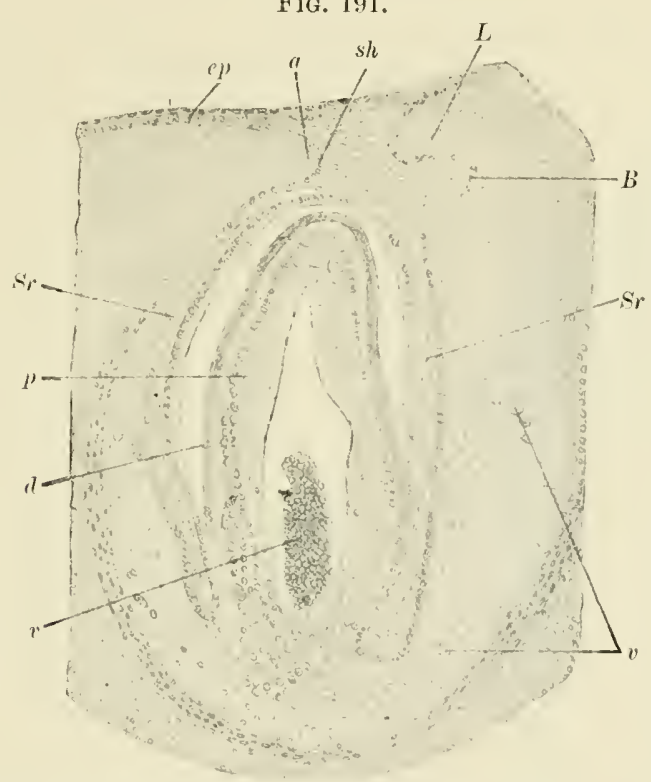

Section of developing tooth. From embryo of rabit. (Freund.) ep, epithelium of gum; $s h$, epithelial cells formiug outer layer of the enamel-pulp of the temporary tooth; $L$, similar layer belonging to the rudiment of the permanent tooth; sr, enamel-puly; $p$, deutal pul, of the tooth-eavity; $d$, dentin ; $v$, bloodvessels; $B$, rudiment of second or permanent tooth; $a$, embryonic connective tissue of the alveolar Irocess.

The Teeth.-The development of the teeth presents elose analogies to that of the hairs. They also first appear as little masses of cells, growing into the connective tissues of the alveolar processes from the stratified epithelium covering them. Into the bases of these masses connective-tissue papillie are developed, which eventually become differentiated into the pulp of the tooth-cavities. The epithelial cells which immediately surround these papillæ become elongated to a columnar form and then become converted into or elaborate the tissue of the enamel. The superficial cells 
of the papilla likewise elongate and produce the dentin. The cement which eonstitutes the onter layer of the root of the tooth is hone, and is developed from the fretal connective tissue in that region (Figs. 190 and 191).

Only a brief description of the structures entering into the formation of the fully developed tooth ean be given here. For a more detailer acconnt of them the student is referred to special works on the subject.

The eentre of the tooth is hollow, and the eavity opens by a small orifice at the tip of the root. This eavity is filled with a

FIG. 192.

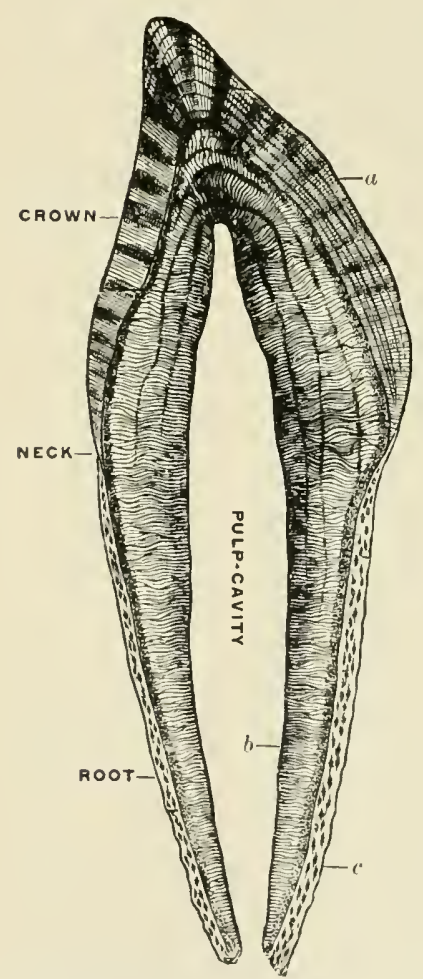

Axial section of a human tooth having but one root: $a$, chamel; $b$, dentin; $c$, cement. highly vascular delicate areolar tissue, richly supplied with nerves. Where this pulp is in contact with the tooth its onter layer is made up of modified connective-tissue cells, odlontoblasts, which are calpable of elaborating dentin. The borly of the tooth is eomposed of dentin. This contains minute canals, analogous to the canaliculi in bone, but much longer. They extend from the pulp-eavity nearly, if not quite, to the onter boundiary of the dentin, and, toward their terminations, give off branches. These canals are oceupied by long fibrous processes of the odontoblists already mentioned.

The crown of the tooth, down to its neck, is covered with enamel. This is a tissue derived from epithelium, and is composed of long, prismatic elements extending from the surfaee of the tooth to the dentin. These prisms have a polygonal eross-section and are held together by a hard cement-substance. They are not perfeetly rectilinear, but pursuce a wavy course, being disposed in lamina or bundles, in which the prisms have not quite the same direction.

The root of the tooth, below the point where the enamel ends, is eovered with eement, which has the structure of ordinary bone, but is usually devoid of Itaversian camals (Fig. 192). 


\section{CHAPTER XVII.}

\section{THE REPRODUC'TIVE ORGANS.}

\section{IN THE FEMALE.}

Tine female reproductive organs are: (1) the ovary, in which the egg is produced; (2) the Fallopian tube, through which it is conreyed to (3) the uterus, where it develops into the foetus, and from which the ehild at maturity passes through (4) the vagina and (5) external genitals into the external world.

1. The Ovary (Fig. 193). - The free surface of the ovary is covered with a single layer of columnar epithelium, called the "germinal epithelium." Bencath this the substance of the organ is composed of a rasenlarized fibrous tissue, the "stroma," which is slightly different in the details of its structure in different parts of the organ. Immediately beneath the germinal epithelinm it is slightly rieher in intercellular substance than in the subjacent parts, so that the organ appears to have a proper fibrous coat. This coat is not distinct, however, and gradually passes into a highly cellular form of fibrous tissue, in which the spindle-shaped cells are separated by only a small amount of a delicate fibrous intercellular sulstance. Toward the hilum of the ovary this connective tissue passes into a more distinetly filorous tissue, containing a larger amount of intercellular substance and cells that are less prominent. In this portion of the stroma the larger vessels supplying the organ are situated, and from it they send smaller branches throughout the stroma of the organ. Within the more cellular regions of the stroma are the structures known as the Gratian follicles, each of which eontains an ovum. In orter to understand the structure of these Graafian follicles it will be well to trace the history of their development.

The Graafian follicles and ova are derived during foetal life from the germinal epithelinm covering the ovary. From this layer of cells little columns of epithelium make their way into the stroma, where they become broken up into small isolated groups, in each of which one of the cells develops into an ovum, while the rest contribute to the formation of the Graafian follicle. This mode of origin 
may serve to explain the fact that the yomnger Graafian follieles are most abundant in the peripheral portion of the stroma. At first the Gratian follicle consists of a large central cell, the ovum,

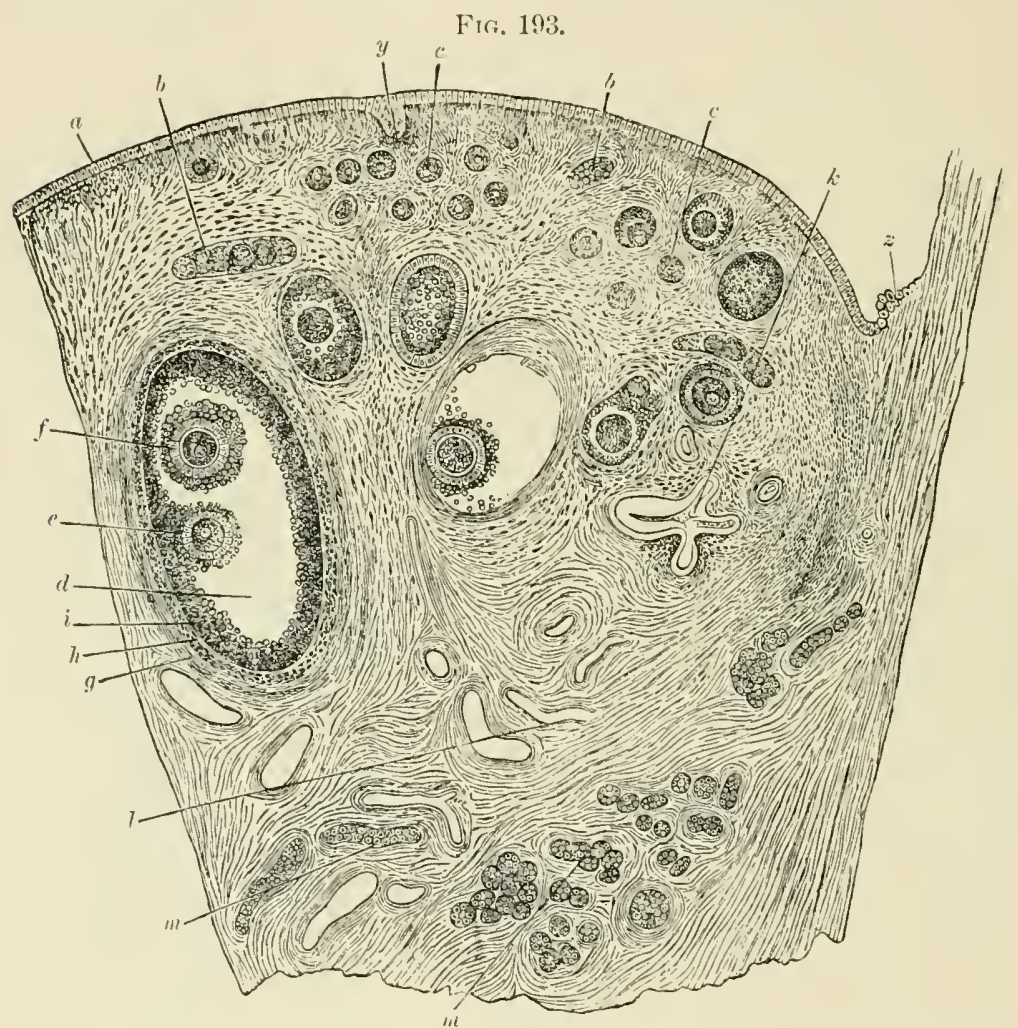

Section from the ovary of an aclult bitch. (Waldeyer.) $a$, gerninal epithelium: $b, b$, columns of germinal epithelium within the stroma: $r, c$. small follicles; $d$, much more advanced follicle; $e$, discus proligerus and ovum: $f$, sccond ovum in sane follicle (a rare occurrence) $: g$, fibrous coat of the follicle; $h$, basement-membrane; $i$, membrana granulosa of epithelium: $d$, liquor folliculi: $k$, old follicle from which the ovum has been dis. charged (corpus album); $l$, bloodvessels: $m, m$, sections of the parovarium ; $y$, ingrowth from the germinal epithelium; $z$, trausition from the germinal epithelium to the peritoneal cndotheljum.

surpounded by an envelope of somewhat flattened epithelial cells, which are in direet eontact extermally with the mumodified, highlyly cellular tissue of the stroma (Ficr. 194).

As the Gratian follicle develops, it position in the ovary becomes more central, and the eclls aromm the ovmm Inse their flattened shape and divide, forming a donble laver of enbical or colmmnar cells. These two layers then beenne separated by a clear flud, 
the liquor follienli, so that the outer layer forms the wall of a sac, while the inner layer remains as a close investment of the ovum. The cells of these two layers multiply: those surrounding the ovum forming the "disens proligerus," and those lining the sac the "tuniea granulosa" ; but they blend with each other at one point on the wall of the follicle, so that the ovum retains a fixed position (Fig. 195).

Meanwhile the tissue of the stroma undergoes modifieations which

FIG. 194.

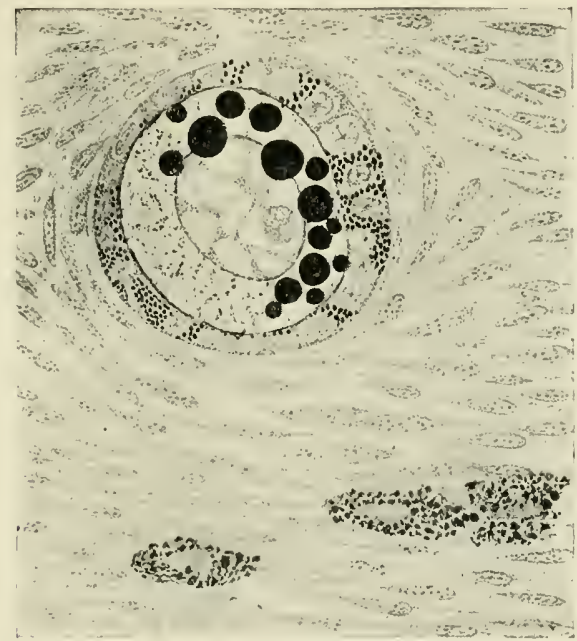

Graatian follicle and stroma in ovary of adult sow. (Plato.) The ovum oecupies the centre of the folliele, appearing as a very large cell with a large vesieular nueleus ("germinal vesiele"), within which is a large nueleolus ("germinal spot"), exceeding in size the whole nueleus of the surrounding epithelial cells of the folliele. The eells of the stroma are arranged about the follicle as though to form the fibrous eoat of the latter. In the lower portion of the figure are three large eytoplasmic eells, eontaining globules of fat and granules of pigment. These cells are analogous to those found in the interstitial tissue of the testis. The epithelium of the Graafian follicle, and the ovum, also eontain globules of fat of various sizes, stained blaek by the osmie aeid used in the preparation of the specimen.

contribute a clear basement-membrane and a fibrous envelope, the "membrana propria," to the structure of the follicle.

The follicle now enlarges, as the result of an increase in the amount of the liquor folliculi, eventually approathes the surface of the ovary at some point, and then ruptures, discharging the ovum.

After the rupture of the Graafian follicle and the eseape of its contents a slight hemorrlage usually takes place into its cavity, which then appears filled with remains of the liquor follieuli mixed with eoagulated blood. The cells of the tunica granu- 
Fici. 195.

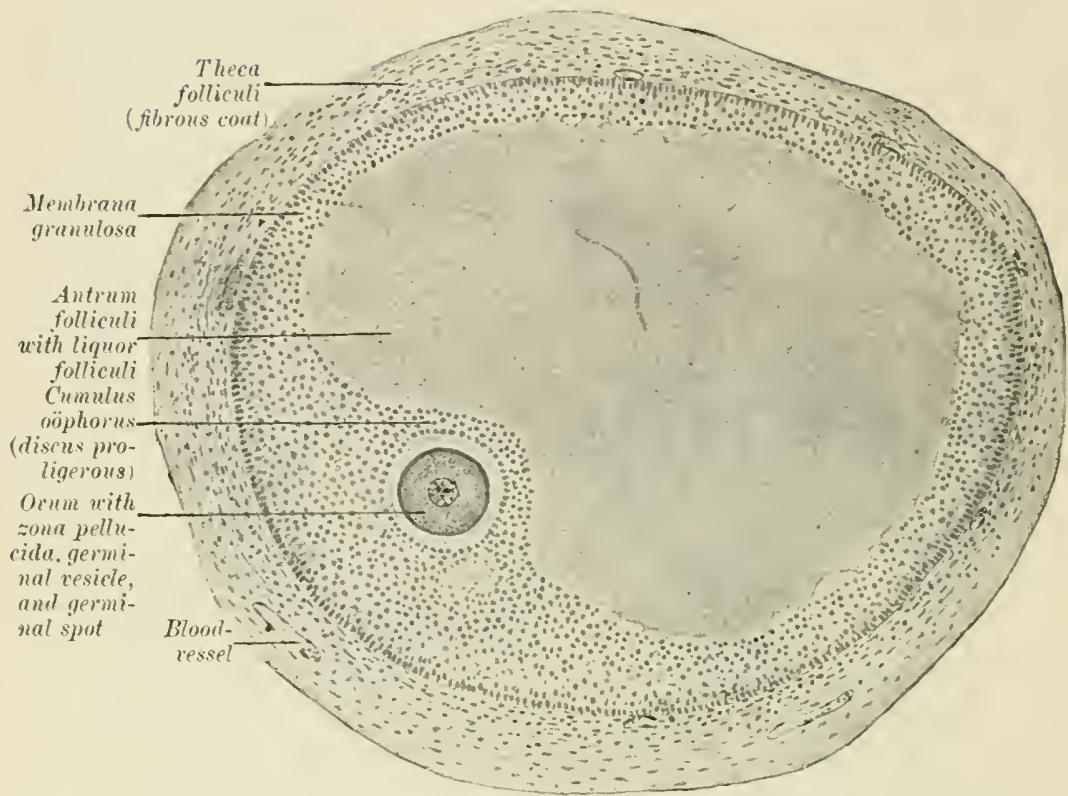

Section through a Graafian follicle from an ape's orary. ( $\times 90$.

FIG. 196.

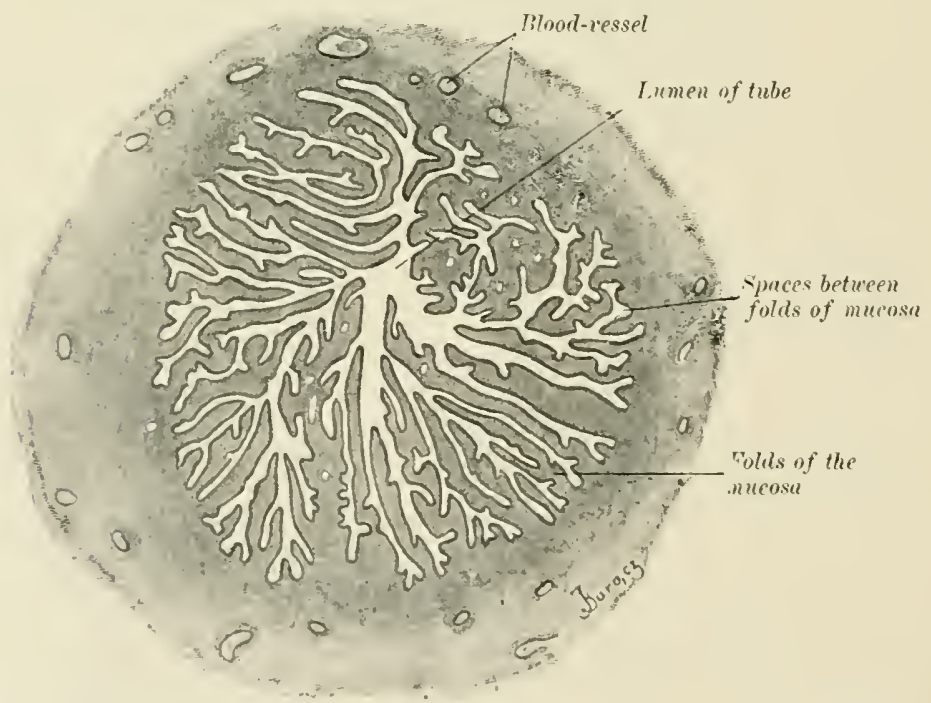

Transverse section through the ampulla of the Fallopian tube of a young woman. ( $\times 25$.) 
lo:a, epithelial in nature, now enlarge and probably also proliferate so that this layer of cells becones greatly thickened. The eells of the connective tissue upon which the tunica gramulosi rests also proliferate and columns of them penetrate among the epithelial eells, which they very closely resemble, and later these ingrowths of connective-tissue cells become vascularized with loops of eapillary blood-

FIG. 197.

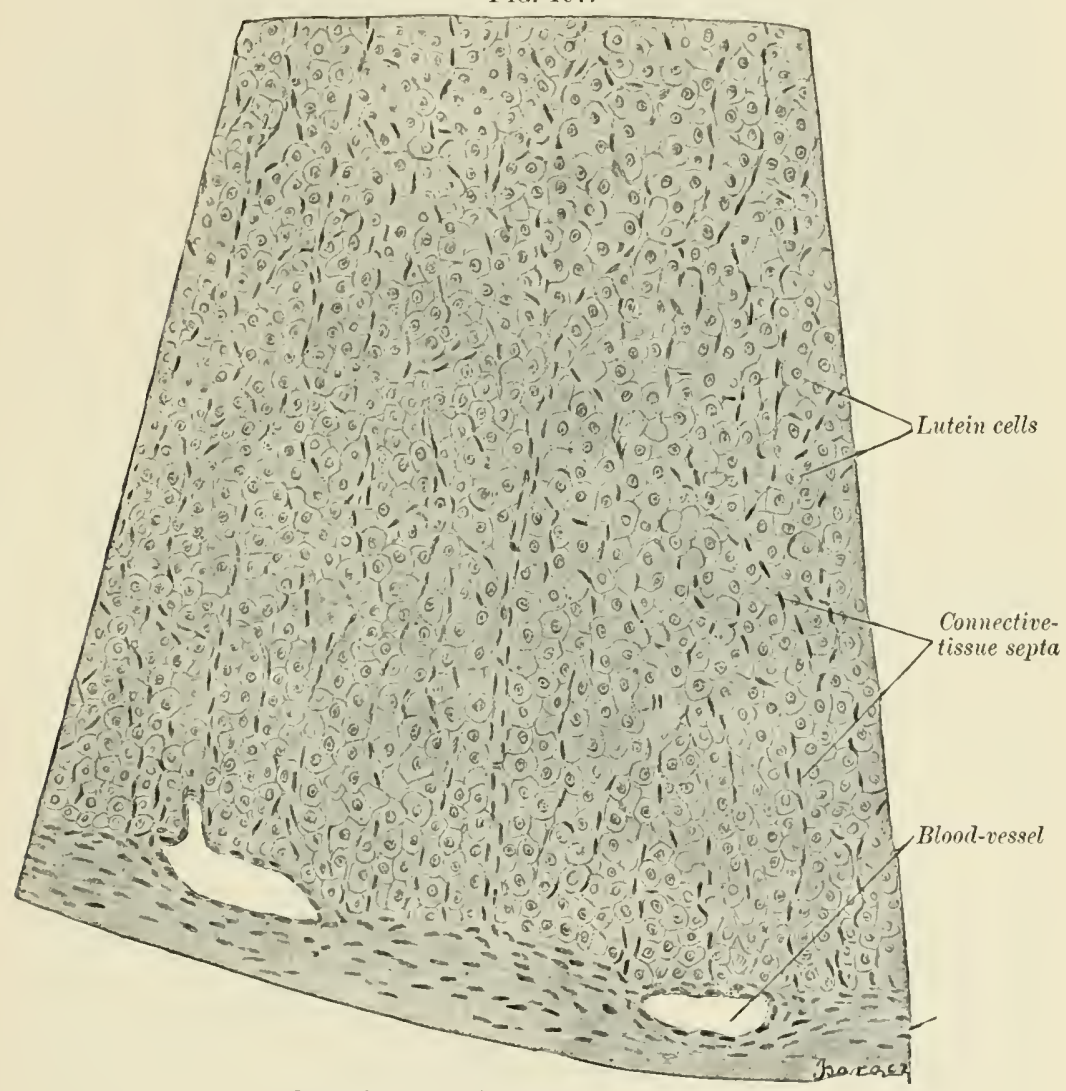

Part of a corpus luteum of a bitch. ( $\times 300$.

vessets sprouting from the older vessels of the stroma. While this growth of connective tissue is taking place, the epithelial cells undergo retrograde changes which are characterized by the appearance of fat droplets in the cytoplasm, giving the tissue a yellow color when they are abundant. For this reason the cells are called lutein cells. This process gradually leads to the ultimate destruction of the epithelium, which is replaced by connective tissue. Fibres 
develop in the latter, and eventually the follicle is reduced to a small mass of dense fibrous tissue (corpus alhum, Fig. 193, $k$ ). If preguancy occurs during the progress of these changes, they are much slower than if pregnancy is alsent. In the latter case the epithelium does not become so prominent and the follicle is not so yellow, but passes from the hemorrhagic to the fibrous stage more rapidly (corpus hemorrhagicum). When pregnancy exists, the lutein cells are more prominent in the composition of the mass and the follicle is more yellow in color (corpus luteum, Figs. 196 and 197). The corpus album formed from the corpus luteum is also larger than that derived from the corpus hæmorrhagicum.

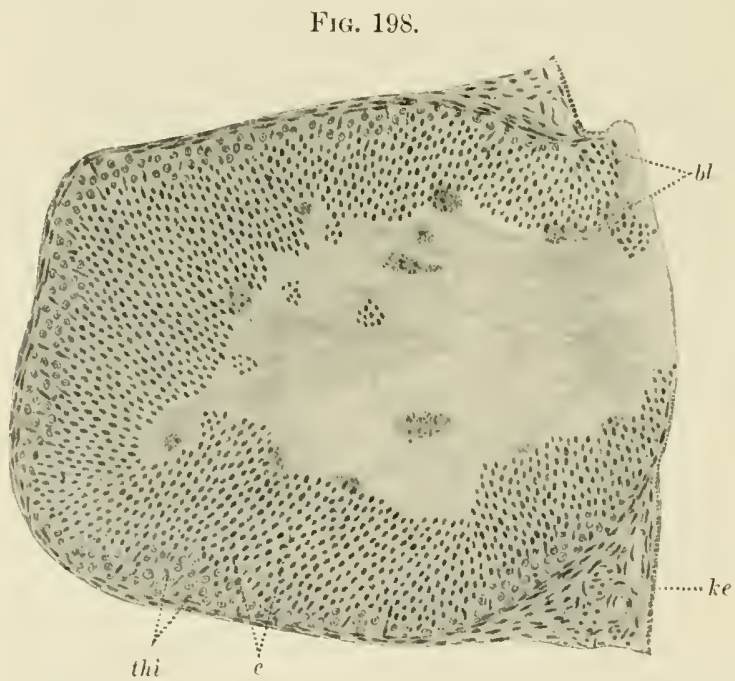

Section from rabbit's ovary, illustrating the formation of the eorpus luteum. (Sobotta.) Recently ruptured Grafian folliele. ke, germinal epithelium; beneath it, the ovarian stroma. Bounding the follicle externally is the fibrous capsule of the follicle. Within this, thi, is a layer of proliferating fibrous tissue, composed of polyhedral eells with round nurlei. Among these are elongated nuelei belonging to enclothelial cells springing from the apillaries, and destined to form the walls of future bloodvessels; $e$, epithelium of the membrana granulosa. Within this are the viseiul remains of the liquor follieuli, eontaining a few rel blood-corpuscles and some epithelial eells detached from the membrana granulusa, bl, red blood-rorpuscles. This seetion was prepared from an ovary about twenty-four hours after coitus, and the development of the layer thi probably took place within that time.

2. The Fallopian Tube-CThe free surfice of the Fallopian tulse is covered by a serous membranc, eontinuous with the rest of the peritonemm. This rests upon fibrous tissue, in which the longitudinal bundles of smooth muscular tim-ne constituting the external 
Fur: 199.

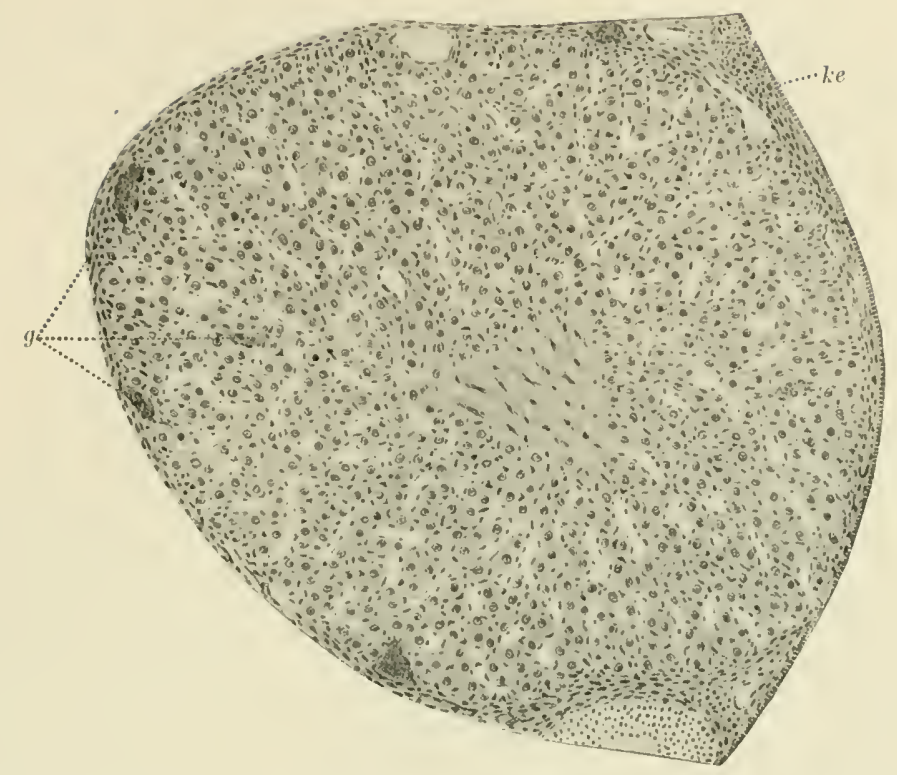

Section of corpus luteum four days after coitus. Rabbit. The proliferating connective tissue has nearly filled the cavity of the follicle, only a small mass of fibrin remaining in its centre. The young connective tissue is highly vascularized, the blood in some of the capillaries being represented, $g$. ke, germinal epithelium. Below is the margin of a Graafian follicle, with its membrana granulusa.

muscular coat are situated. This is followed by an internal muscular coat of encireling loundles of smooth muscular tisine, inside of which is the submucous coat of areolar tissue, containing a few scattered ganglion-cell:-

The mucous membrane consists of a highly cellular connective tissue covered with ciliated columnar epithelitm. During life these cilia propel toward the uterine eavity substances coming into contact with them. Toward and at the fimbriated extremity of the tube the mucons membrane is thrown into deep longitudinal folds (Fig. 200), upon which are numerous secondary and tertiary folds, but further toward the uterus these folds give place to branching villous projections into the lumen (Fig. 201). Toward the uterine end of the tube these complicated folds and villi disapnear and the lumen of the tube becomes round or stellate.

3. The Uterus.-The extermal surface of the uterus, throughout. most of its extent, is cosered by a reflection of the peritoneum. Beneath this are three distinct coats of smooth muscular tissue, the 
onter two in close contact with each other; the two inner separated by a thin layer of areolar fibrons tisise, supporting large bloodvesscls. This separation of the innermost layer from the middle layer leads to the inference that the former is analogons to the muscularis mucose found in other hollow viscera, although in the uterus it forms the chief mass of the muscular tissne of the organ. The onter layer is made up of bundles of fibres that have a general longitudinal position; the two inner layers have a general circular

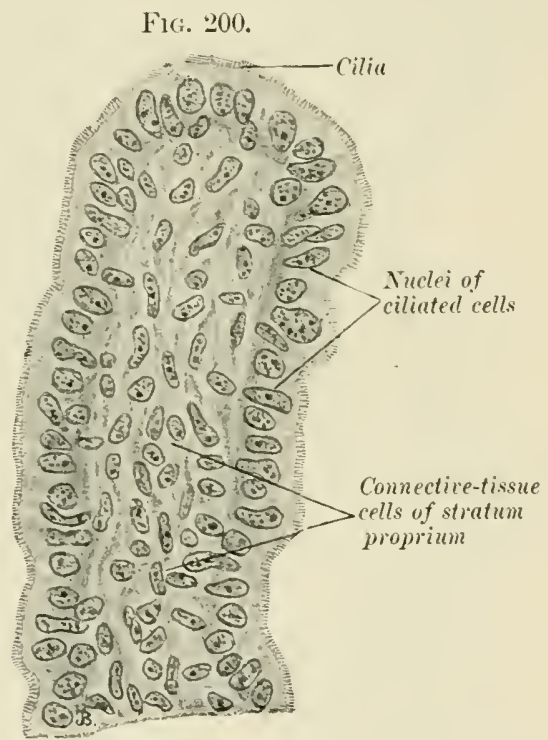

From a section through a fold of the mucous membrane of a human Fallopian tube. ( $\times 480$.)

disposition of their bundles, though the latter interlace with each other in various directions within the muscularis mucosæ, leaving masses of areolar tissue containing the larger bloodvessels between them.

Covering the surface of the muscularis mueosæ is a highly cellular connective tissue. It is componed of round and fusiform cells, lying in a small amount of intercellular substance, in which fibres can be distinguished only with difficulty. The surface of the mucous membrame is covered with a layer of ciliated colummar epithelium, which is continued into long tubular glands penetrating the superficial portions of the muscularis mucosæ, where they frequently branch before terminating in blind extremities. It should be borne 
in mind that at the extremities of these glands the whole tubule is often filled with epithelial cells, so that no lumen is visible. In their course into the mucous membrane these glands are usually straight at first, but in their deeper portions become tortuous (Figs. 202 and 203).

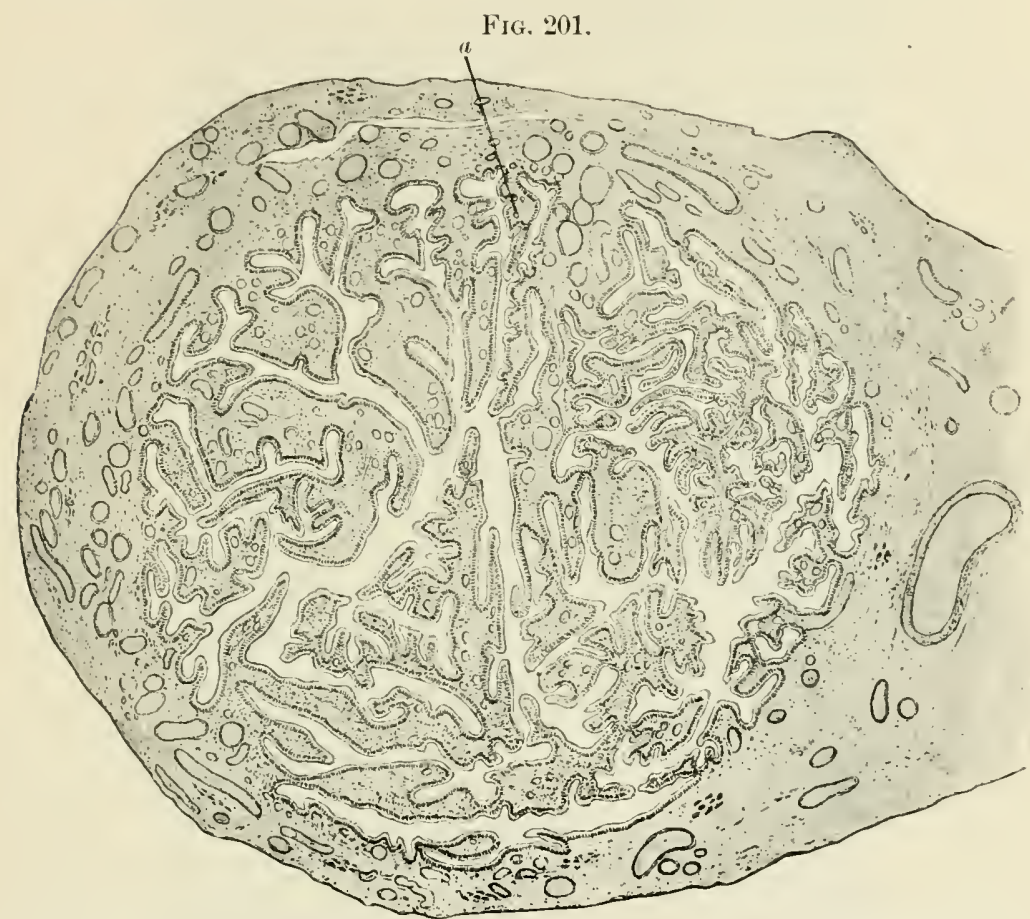

Transverse section of the Fallopian tube near its free end. (Orthmann.) Numerous branching villous projections of the wall, covered byciliated colum r epithelium, extend into the lumen. The open spaces in these villous projections are seetions of the bloodvessels.

During the childbearing period of life the portion of the mucous membrane resting upon the musenlaris mueose is the seat of aetive ehanges which pass through a eyele corresponding to each menstrual period, but interrupted by a special series of elanges during pregnaney. These changes are of importance in their bearing upon the pathology of the organ, and must be briefly described.

At the menstrual period the superficial portion of the mueous membrane, down to its museular coat, suffers a degeneration, which results in its disintegration and diseharge, along with some blood derived from the exposed and damaged vessels of small size within its tissues. After this degeneration the membrane is restored by a 
Fig. 202.

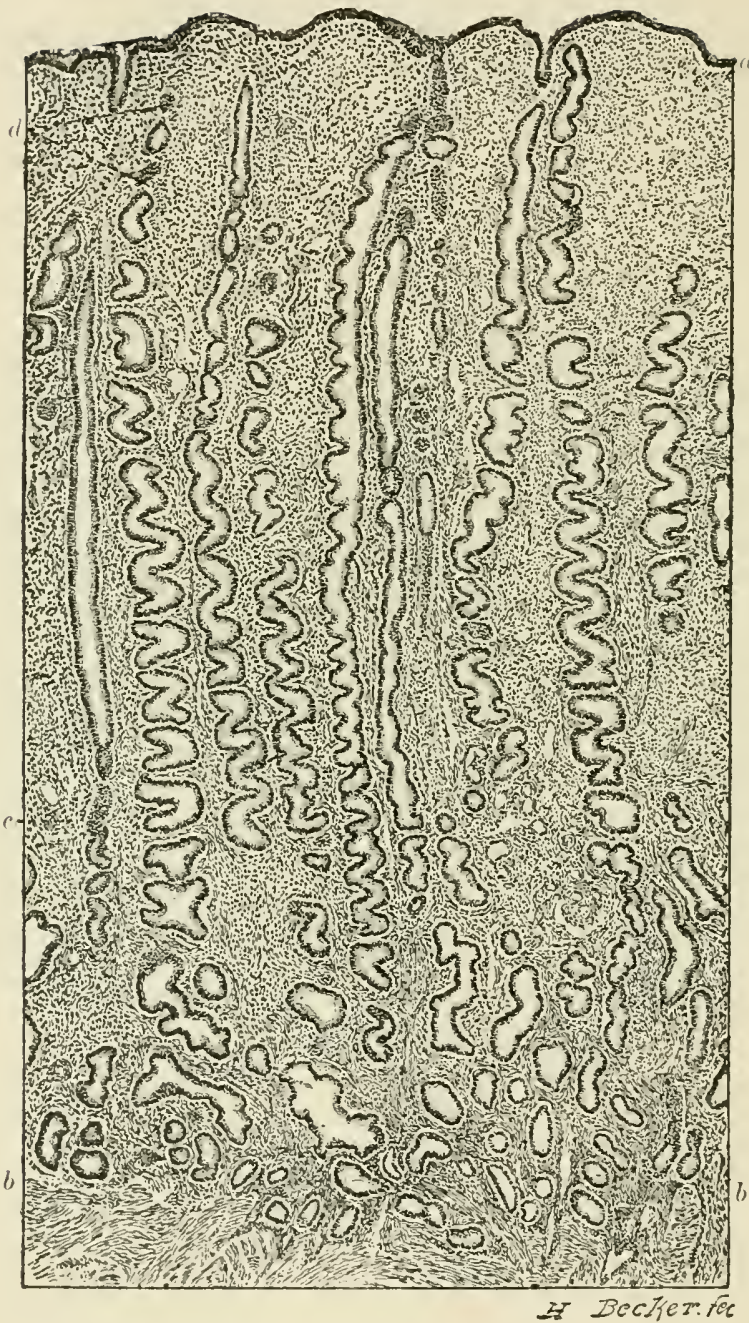

Normal endometrinm in a patient twenty-six years of age. $(\times 25$.

The mucosa is slightly thickened, its surface is wary, and its epithelial covering $a$ is intact. In this section it is possible to trace the glands in their continuity almost from the sur. face to the muscle. A few of them are practically eylindrical throughout, but the majority have a wavy contour presenting a well-defined corkscrew arrangement. Quite a number, cut just along their margin, can be recognized as little masses of epithelial cells; $c$, is eut longiturlinally: $d$, almost transversely. At first sight one would think that there was a great excess of glands in the section, whereas in rcality, at most, there are not more than twelve, the distances between any neighboring two being about the same. The gland epitlelium is intact throughout. The stroma in the superficial portions is rather lax, in the deeper portions more compact. $b$ indicates the line of junction between the muscle and mucosa. Its irregularity is especially noticeable. (T.S. Cullen, Cancer of the Lterus, New York, 1900.) 
proliferation of the elements eontained between the bundles of the musenlaris mueosie, the glands being reformed from the remuants of their deep extremities. The mueous membrane slowly continues

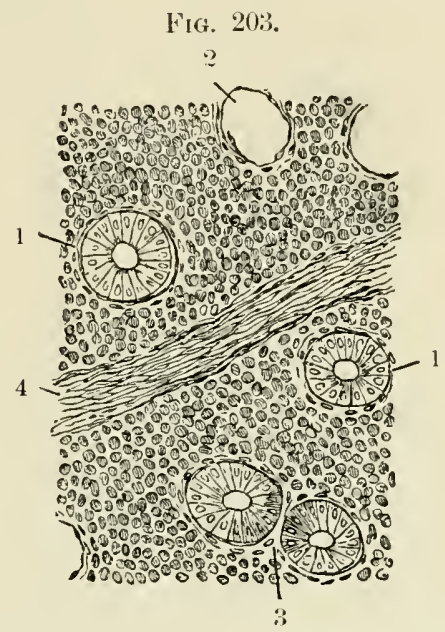

Section of the human uterine mucous membrane parallel to its surface. (Henle.) 1.2, 3, uterine glands in cross-section. In 2 , the basement-membrane alone is represented, the epithelium having fallen out of the section. 4, bloodvessel in longitudinal section. Between these structures is the highly cellular stroma of the mucous membrane, only the nuclei of its cells being represented.

to increase in thickness and the glands in tortuousness until the next menstruation, when the same process is repeated. It will be noticed that the connective tissue of the mueous membrane, in the absence of pregnancy, is subject to periodical degeneration and regeneration, which probally prevent its development into a mature fibrous tissue with an abundance of fibrillated intercellular substance.

If an ovum, diseharged from the ovary, becomes fertilized, the nenstrual cycle of ehanges in the superficial portion of the mucous membrane of the uterus is interrupted. That portion of the mucons membrane then undergoes extensive modifieations in strueture during the early months of the ensuing pregnancy. The tissue between the uterine glands becomes more hyperplastic than during the intervals separating the menstrual periods, and at the same time some of the cells composing it become hypertrophied until they closely resemble large epithelial cells. These cells have been called "decidual cells," and oceasionally contain more than one nucleus. When there are several nuclei in a single cell, it is called a giant cell. The bloodvessels and glands in the mucous membrane also 
become enlarged, so that the whole mucosa is greatly thickened. Later in the course of pregnaney compression by the growing foetus and increased amount of amniotic fluid cause a condensation of these tissues, which become more fibrous with flattened spaees representing the uterine glands, the lining epithelium of which becomes diminished in size and flattened. These changes occur in those portions of the mucous membrane, the deeidua vera, which do not take part in the formation of the placenta. The ovum, when it reaches the eavity of the uterus, becomes embedded in this tissue, which grows around and encloses it, after which it is differentiated into three portions. The part beneath the ovum is called the decidua serotina; that which invests the ovum, the decidua reflexa; and that lining the rest of the uterine cavity, the decidua vera. As the ovum enlarges, the decidua reflexa comes in contact with the decidua vera, and the two layers exert a mutual pressure upon each other, which flattens the spaces they contain and may obliterate many of them. These atrophic changes are most marked in the deeidua reflexa, which, according to some anthors, entirely disappears or is reduced to a thin layer blending with and indistinguishable from the decidua vera. The disappearance of the superficial epithelium of the mucosa removes what might otherwise be a certain means of distinguishing these layers. The decidual tissue now consists of a number of flattened spaces which are separated from each other by thin walls of fibrous tissne produced by the further development of the decidual tissue. The decidua reflexa and the decidua vera blend with each other to form a part of the membranes that are expelled from the uterus, along with the placenta, after the birth of the child. The placenta is formed in the decidua serotina, and the changes in this portion of the uterine mucosa during pregnancy differ from those in the deciduæ vera and reflexa. Most of the tissues which constitute the afterbirth at parturition are of foetal origin. The outer surface of the ovum, when it reaches the uterus, is composed of a single layer of ectodermal rells; beneath this is a layer of embryonic connective tissue, derived from the nesoderm and resembling mucous tissue, with few if any fibres. These two layers of tissue form the outer envelope of the ovum, the chorion. Through a proliferation of the ectodermal cells, little projections, or villi, are formed on the surface of the elorion, and subsequently the mesodermal connective tissue grows into these villi, so that it forms the central part of each villus, covered with a single layer of ectodermal epithelium. 
Still later, vascular loops from the allantois penetrate into the villi, and the latter subdivide dichotomously to form the cotyledons of the placental. During this growth of the villi the ectodermal cells covering them divide in such a way that the covering consists of a double layer. The cells of the more superficial layer are not distinguishable from each other, but blend so as to form a layer of cytoplasm containing many nuclei, a structure called a syncytium (Fig. 204). The ectodermal cells beneath this syncytium are at first

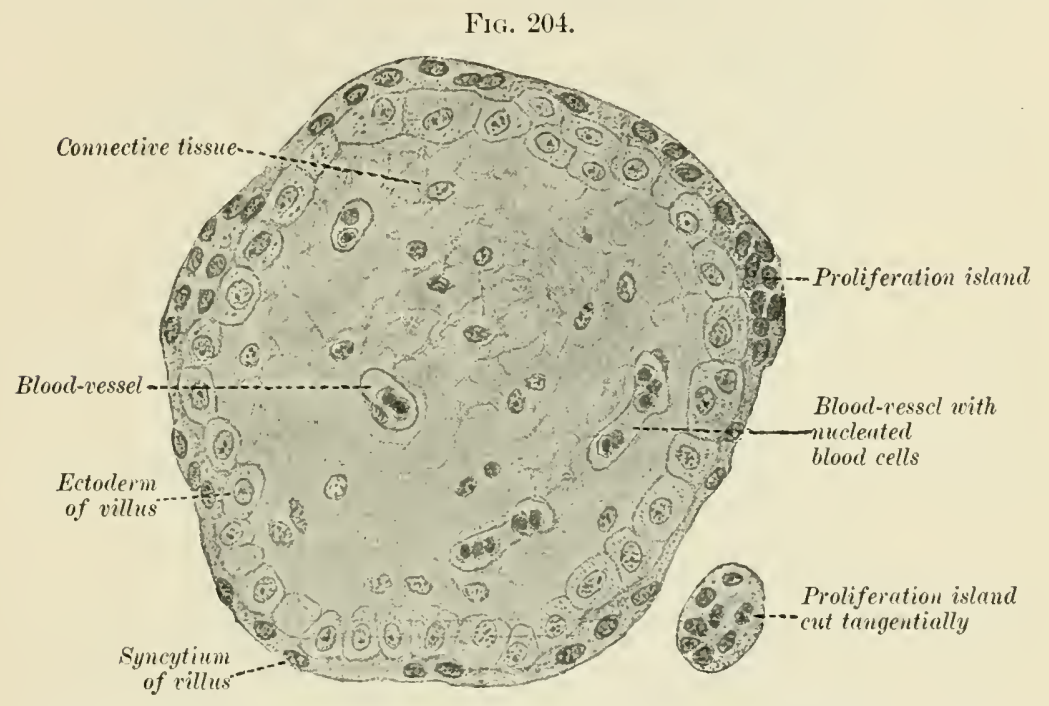

Transverse section of a human chorionic villus at the fifth month of pregnancy. ( $\times 300$.

distinet, but during the later months of pregnancy they disappear. leaving only the syncytium, in which there are occasional thickenings, called proliferation islands (Fig. 204); still later, the syncytium also becomes altered, its nuclei disappear, and the whole layer is converted into a hyaline substance, "canalized fibrin" (Fig. 205).

The placental villi come to occupy large spaces in the placenta through which the maternal blood circulates, interchange of nutrient and wa-te materials and of gases taking place between the maternal and foetal blood through the tissues of the villus. There is still some doubt as to the way in which these cavernous blood-spaces are formed. According to one view, they are dilatations between the uterine mucosa and the foetal parts of the placenta, into which the bloodvessels open. Another view is that the villi penetrate into the dilated vessels of the decidua serotina. Those who hold this view 
also believe that the villous syncytium is not derived from the chorionic ectoderm, but from the uterine epithelium. In sections of these tissues, while the placenta is developing, it is extremely difficult, often impossible, to decide whether given cells are of foetal or maternal origin (Fig. 206). After the birth of the child and the expulsion of the membranes the uterine mucous membrane is regenerated from the tissues remaining in the superficial layers of the muscularis mucosæ.

Fia. 205.

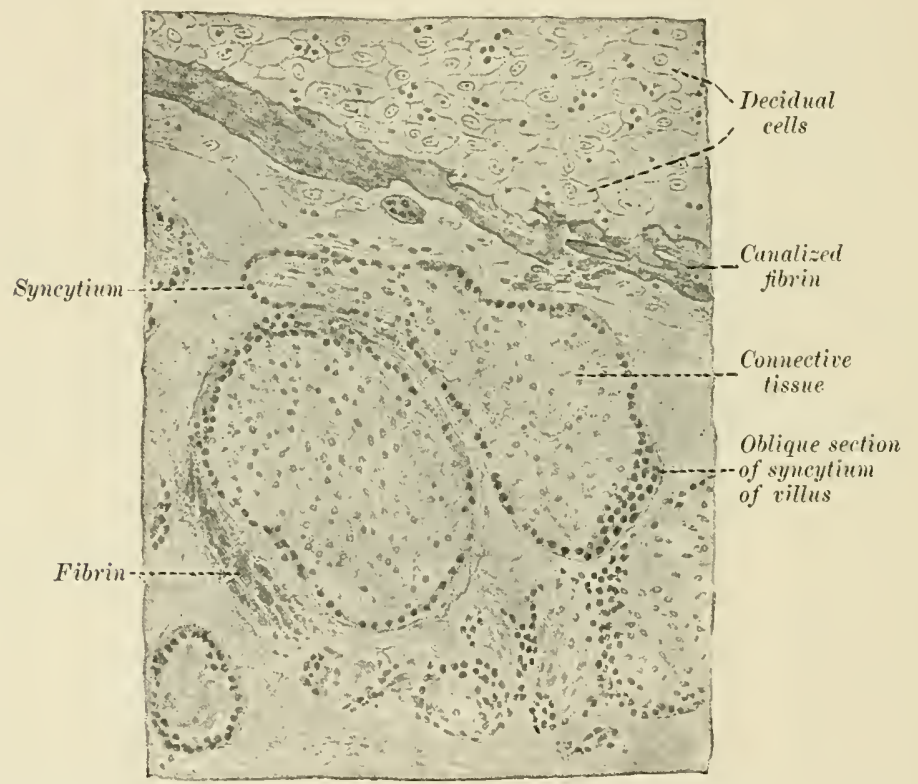

From a section through a human placenta at the fifth month of pregnancy. ( $\times$ so.)

The mucous membrane of the cervical portion of the uterus does not partieipate in these changes incident to menstruation and pregnancy, and the connective tissue underlying its epithelial lining is more fibrous in character than that in the corresponding part of the uterine body. Abont the middle of the cervical canal the ciliated epithelim, which is continuous with that of the body, passes into a stratificd epithelium, which extends over the cervix uteri, the portio vaginalis, and the inner surface of the ragina to join that of the epidermis upon the labia minora. The fibrons tissue beneath this stratified epithelium possesses papilla similar to those upon the skin, and contains mueigenous glands, which secrete a tenacious 
mueus serving to close the cervical canal during pregnancy. The orifices of these glands sometimes become oceluderl, causing a cystic dilatation of the acini, due to aceumulated secretion, "ovula Nabothi."

FIG. 206.

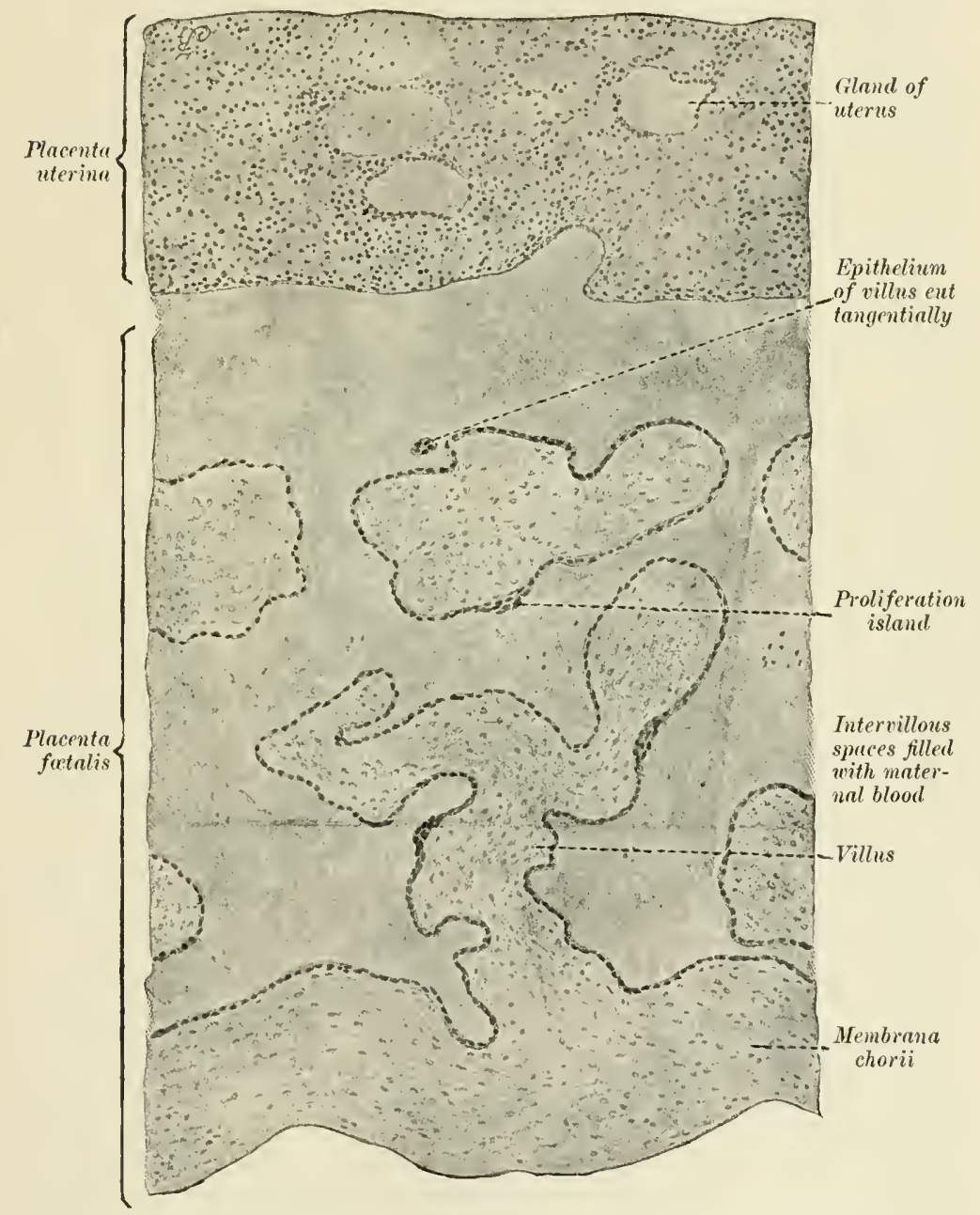

Transverse section through a human placenta at the second month of pregnancy. (After a preparation by 1'rof. Nars.) ( $\times 50$.

The muscular and other tissues of the uterine wall undergo hypertrophy during pregnaney, the indivioiual muscular fibres becoming as much as thirty times their original bulk in the non-preg- 
nant uterus. The bloodvessels also enlarge and acquire thicker walls. These retain much of this increase of size, even after the involution of the nterns following parturition, but the muscular fibres suffer a partial fitty degeneration, which restores them to nearly their original condition.

4. The Vagina (Fig. 207).-The subepithelial fibrous coat of the vagina is covered with small papillæ, which project into the epithe-

FIG. 207.

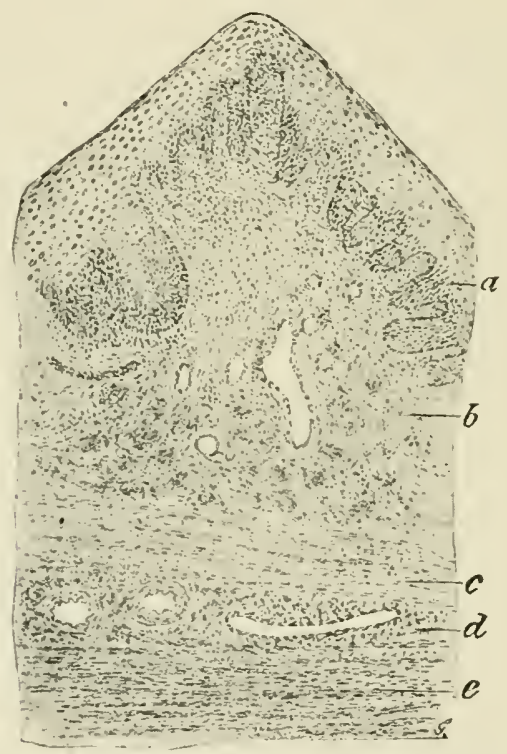

Portion of a longitudinal section of the raginal wall. (Benda and Guenther's Atlas.) $a$, stratitied epithelium; $b$, subepithelial areolar tissue; $c$, muscularis mucos $; d$, areolar submucosa containing vascular trunks; $\epsilon$, muscular coat. Outside of the latter is the ill-defined fibrous coat, not represented in the figure.

lium. Outside of this coat is one of smooth muscular tissue, which is not elearly divisible into layers, but in which the inner fibres are chiefly circular, forming an imperfectly defined muscularis mucosæe, while the outer have a longitudinal direction, and may be regarded as the true muscular coat of the vagina. Outside of the muscular coat is a layer of areolar tissne connecting the vagina with the neighboring parts, except at its posterior and upper part, where it is covered with a serous membrane, forming part of the peritonetim.

5. The External Genitals.-The hymen is a fold of the mucous membrane, and consists of fibrous tissue with a covering of stratified epithelium. The same general strneture obtains also in the labia 
minora, prepuce, and labia majora ; hut the labia minora and prepuee are destitute of fat, while the labia majora contain considerable adipose tissne. All three organs are supplied with sebaceous glands, which are numerous beneath the prepuce and are associated with hairs only on the labia majora. The latter also contain fibres of smooth musenlar tissue, corresponding to the analogous dartos of the scrotum. 'The bulbi vestibuli, crura of the clitoris, and the body and glans of that organ are composed of ereetile tissne. The glands of Bartholin are compound racemose glands, in which the alveoli are lined with a columnar epithelium resembling in strueture that of the mucous glands in other parts of the body. 'The epithelium lining their ducts is of the cubical variety.

The parovarium is a remmant of the Wolftian body of the foetus, consisting of a series of blind tubules lined with epithelium (Fig. 193). It is situated between the Fallopian tube and the ovary. The remains of the Wolffian duet and of the duct of Müller, having a similar structure to the tubules of the parovarium, are sometimes persistent, the one connected with the parovarim, the other with the extremity of the Fallopian tube. These structures are of interest because tumors occasionally arise from them.

The Maturation of the Ovum.-Before the ovarian ovum is ready for fertilization it must undergo two divisions, during which the amount of chromatin left in the mature egg is reduced one-half. The first division results in the formation of two cells, which differ enomously in the amount of cytoplasm they possess, but which have equal shares of the chromatin in the original melens. The smaller of these two cells is known as the "first polai body." After its separation from the larger cell both cells divide again, without an intermediate growth of the ehromatin. In this second division of the larger cell the two resulting colls are again very unequal in size, the smaller being the "seeond polar body." 'The first polar body having also divided, there result from these successive divisions one matmre egg and three polar bodies, each with only half as many chromosomes in its nucleus as are commonly found in the general or" somatic" cells of the body (Fig. 208). "The polar bodies perish, as does also the ovum, unless fertilized by the introduetion of a spermatozoon. The latter, as we shall see, also eontains half the number of chromosomes contained in the somatic cells; so that after its entrance into the mature ovum the latter aequires its full complement of ehromosomes and is ready for derelopment. 
The Mammary Gland.-Each mamma eonists of a group of about twenty similar compound racemose glands, opening by distinct orifices at the tip of the nipple, and separated and enclosed by fibrous tissue, in which there is a variable amount of fat. At the edges of the mamma this fibrous stroma becomes continuous with the tissues of the superficial fascia in which the breast is situated.

Each of the glands entering into the composition of the breast possesses a single main duct, the "galactiferous duct," which is lined with columnar epithelium, except near its orifice, where the strati-

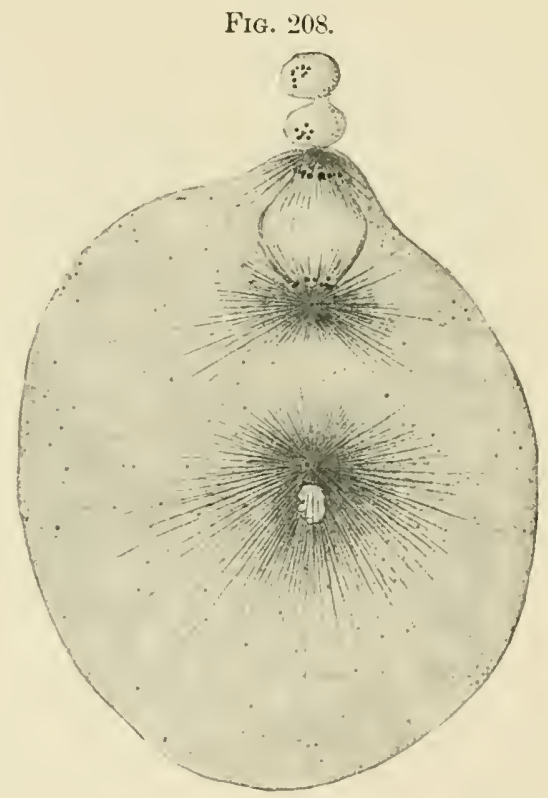

Maturing ovum of physa (fresh-water snail). (Kostanecki and Wierzejski.) Abore are the two small cells resulting from the division of the first polar body. Below is the ovum, the nucleus of which is dividing to form the second polar body. Near the centre of the ovum is the nucleus of the spermatozoon, just above which is its (divided) centrosome with surrounding radiations in the cytoplasm. When the second polar body has been formed the chromosomes remaining in the ovum will be ready to participate with those of the spermatozoon in the further development of the then fertilized egg.

fied epithelium of the epidermis extends for a short distance into its lumen. A little below the base of the nipple the duct presents a fusiform dilatation, called the "ampulla," which serves as a reservoir for the comparatively small amount of milk secreted in the intervals between nursings.

The main duct branches in its course from the nipple into the 
deeper portions of the grland, and these branches give off twigs, which terminate in the tubular alveoli of the gland. The columnar epithelium lining the main duct gradually passes into a culical variety in the branches, and this becomes continuous with the epithelial lining of the alveoli. The terminal branches of the ducts are short, so that the alveoli opening into them lie close together and are collectively known as a "lobule" of the gland. These lobules are, in turn, grouped into lobes, each of which corresponds to one of the main duets of the breast.

The individual alveoli and the lobules are surrounded by fibrous tissne, which may be subdivided into an intralobular and an interlobular portion, the latter more abundant than the former. This fibrous tissue supports the ressels and nerves supplied to the gland.

The character of the epithelium lining the alveoli varies with the functional activity of the gland.

Before puberty the seereting acini are only slightly, if at all, developed, the mamma consisting of a little fibrous tissue and the ducts of the gland, which possess slightly enlarged extremities.

When the gland has become fully developed, at or abont puberty, the epithelial cells lining the acini are small and granular and nearly fill the diminutive lumina. The fibrous stroma is, at this period, abundant and makes up the chief bulk of the breast.

When the gland assumes functional activity the cells enlarge and multiply (Fig. 209), and the lumina of the acini become distinct and fillerl with a serous fluid. Into this fluid a few fat-globnles are discharged from the epithelial lining, forming an imperfect milk, very poor in cream and differing in the proportions of the dissolved constituents from the milk that is produced after the function of the gland is fully established. This secretion is called "colostrum." Besides the scant supply of fat-globules which it contains, it is further characterized by the presence of so-called colostrum-corpuscles. These are leneocytes which have wandered into the acini of the gland from the bloodvessels in the interstitial tissue, and have taken some of the fat-globules of the secretion into their cytoplasm. This process results in an enlargement of the lencocyte, and, in extreme cases, to an obscuring of the nucleus and cytoplasm by fat-globules, so that the whole appears as though composed of an agglutination of numerous drops of fat (Fig. 210).

As the functional activity of the gland matures the epithelial 
cells lining its acini produce drops of fat in the eytoplasm bordering on the lumen, and these are subsequently discharged into the lumen, forming the fat or cream of the milk. The casein of the milk appears to be produced in the following manner: it has been observed that during lactation the nuclei of some of the cells present ehanges in form that lead to the inference that they undergo division by the direct mode-i.e., without passing through the phases of karyokinesis. It thus happens that some of the epithclial cells contain two nuelei. These cells, after a while, project into the lumen of the acinus, the two nuelei lying in a line perpen-

FIG. 209.

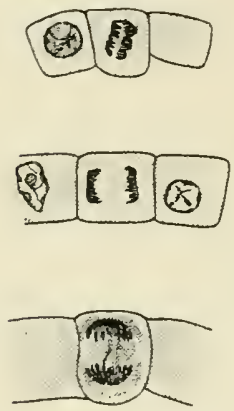

FIG. 210.

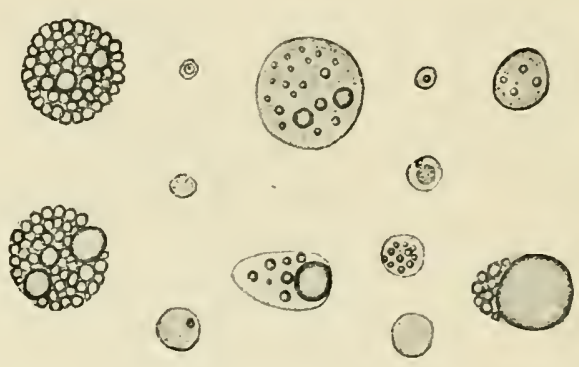

Fig. 209.-Dividing epithelial cells from the mammary gland of the guinea-pig. (Michaelis.) The figure represents the proliferation of the cells by the indirect mode before lactation

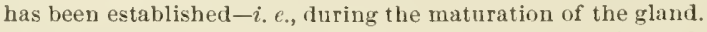

Fig. 210.-Colostrum-corpuscles and leucocytes from the colostrum of a guinea-pig. (Michaelis.)

dieular to its wall (Fig. 211). It is supposed that the nuclei nearest the lumen become detached, together with some of the cytoplasm, and that the ehemieal constituents of the nucleus and eytoplasm enter into the formation of the easein. Such free nuclei have been observed in the limina of the acini, and it is known that the ehromatin which they contain disintegrates and eventually disippears (chromolysis), so that it is not found in the secreted milk. Whether this is, in detail, the exact process by which cassein is formed is still an open question, but that there is an inerease in the nuelear materials of the secreting cells appears certain, and that these nuclei furnish the nueleic acid entering into combination with proteid substances to form the mucleo-albumin, easein, is most probable. The site of the origin of milk-sugar is not known; it appears to be elaborated within the secreting cells. 
When laetation is suspended the breast at first seeretes a fluid in every way resembling eolostrum, and eventually returus to the dormant state, in which the eells are again small and granular and the stroma is relatively abundant.

As the glandular portion of the breast enlarges during lactation, the whole breast beeomes inereased in size, but this inerease is not proportional to the development of the alveoli, for the stroma is redueed in amount, so that the lobules of the gland are eloser to each other. After the period of lactation is passed the alveoli return almost to their original size, but the stroma is not repro-

FIG. 211.

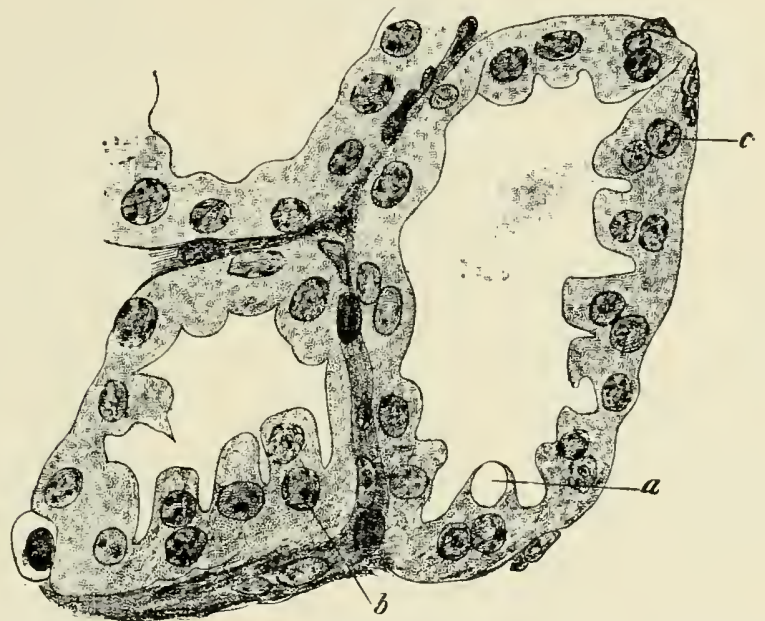

Section from the mammary gland of a guinea-pig during lactation. (Michaelis.) The figure represents sections of two aeini and the margin of a third, separated by richly vascularized areolar tissue. $a$, fat-globule, separated from the Iumen by a mere film of cytoplasm; $b$, projecting cell with two nuclei : $r$, two nuclei which appear to have been produced by constriction of a single pre-existent nucleus.

duced in fibrous form, but its place is taken by adipose tissue, the amount of which depends upon the individual, being great in those that are fat, and slight in those that are lean. In the latter, therefore, the breast hecomes soft and pendulous after laetation has eeased.

It is important to bear the ahove ehanges in the normal gland in mind when examining the mamma for evidenees of a tumor. When, for example, the stroma is abundant and the glandular structures undeveloped, as is the case before puberty, sections of the gland may be mistaken for those of a mammary fibroma. 
The nipple is composed of fibrous tissue, with a considerable admixture of elastic fibres, in which therc are seattered bundles of smooth museular tissue lying parallel to the axis of the nipple. A circular bundle of the same tissue is fornd at the base of the nipple, and by its compression on the bleodvessels may be the eanse of the erection of the nipple. The skin at the base of the nipple and in the areola surrounding it contains large sebaceons glands.

The mammary gland in the male is functionless, and, while it contains the same structures as in the female, it remains in a comparatively undeveloped condition.

\section{IN THE MALE.}

The male organs of generation include the penis, prostate, vesicula seminales, vasa deferentia, epididymis, and testes, together with certain accessory glands.

1. The Penis.-This is formed by three parallel structures: the corpora caremosa, lying side by side and partially blending in the median line, and the corpus spongiosum, sitnated beneath their line of junction and containing the urethra. At its anterior end the corpus spongiosum expands about the ends of the corpora cavernosa to form the glans penis. These three bodies, exeept over the glans, are firmly held together by fibrous tissue, which is condensed at their surfaces to form compact sheaths or external coats enveloping the erectile tissue of which each is composed. The sheaths of the corpora cavernosa are incomplete where they are in contact, permitting the ereetile tissue to blend in the median line. This intercommunication is freer toward the anterior end of the penis than near its root, where the corpora cavernosa are more distinetly separated, preparatory to their divergence to form the erura.

The sheaths of the corpora cavernosa are composed of fibrous tissue eontaining an abundance of elastic fibres. From its inner surface each sheath gives off a number of fibrous hands, ealled "trabeculse," which divide and anastomose with each other, forming the chief constituent of the ereetile tissne. Within these trabeenla are numerous bundles of smooth musenlar tissue.

The rrectile tisine is made up of these trabecula, which give it a spongy charaeter and are covered with endothelial cells, converting the spaces between them into cavernons venons channels. These beeome engorged with blood during erection. The vessels supplying this blood are situated in the trabeculie, and give off eapillary branches, which 
open into the intertrabecular spaces, discharging blood into those

Fig. 212

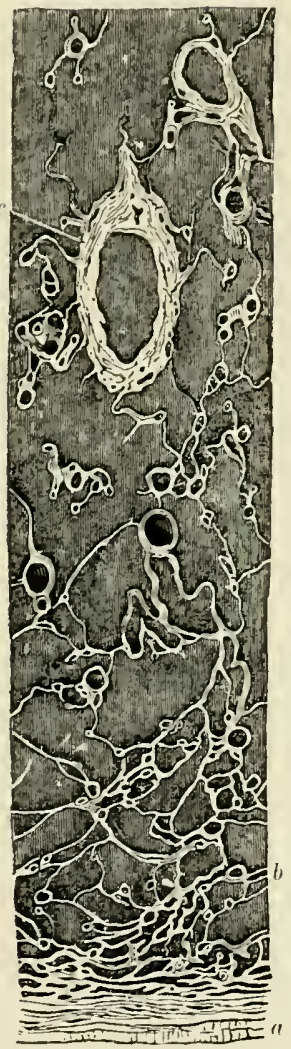
enormously dilated venous radicles. Here and there arterial twigs, surrounded by an investment of fibrons tissne, project from the trabeculie into the venous spaces. These, because of their twisted forms, have received the name helicine arteries (Figs. 212 and 21:).

The structure of the corpus spongiosum is

F16. 213

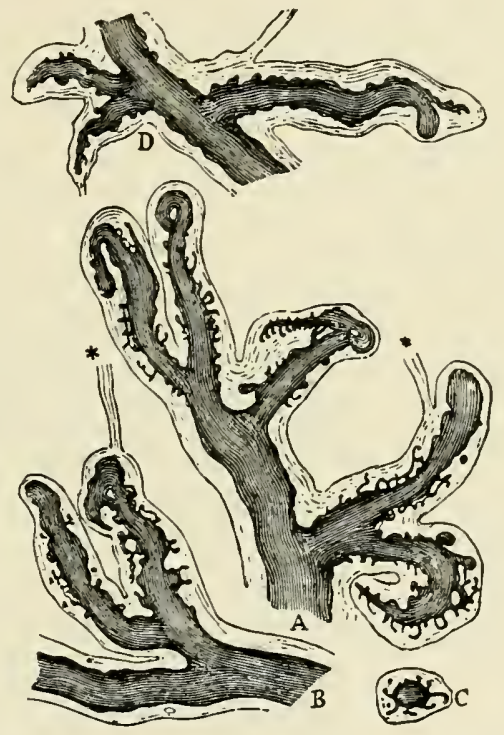

Fig. 212.-Section of injected corpus cavernosum. (Henle.) $a$, fibrous capsule; $b$, trabeculæ: $c$, section of the arteria profunda penis. All the spaces are filled with the material used for injection.

Fig. 213.-Helicine arteries. A, B, C, from the corpus cavernosum; D, from the corpus spongiosum; **, fibrous bands forming a part of the trabecular network.

similiar to that of the corpora eaveruosa, but the trabeculie are more delicate and the spaces between them of more miform size. Its sheath is studded with papillæe where it covers the glans, at the edge of which they are unusually large. They are covered with a layer of stratified epithelium, which conceals them over the surface of the glans, where they are comparatively small, but merely invests the larger ones at the corona. This layer of epithelium is continuons with that of the skin covering the rest of the penis, which is elsewhere loosely connected with the underlying structures by 
areolar tissue levoid of fat. The skin is without hairs on the anterior two-thirds of the penis, but eontains sebaceons glands, which are especially numerous in the fold of the prepuce, where it is attached near the corona of the glans, glands of Tyson.

2. The Prostate.-This body is regarded as the analogue of the uteris, its utricle corresponding to the carity of that organ. It has a fibrous investment, which merges into the areolar tissue connecting the prostate with the surrounding structures and, in its deeper portions, contains smooth muscular tisue, which accompanies it in forming the stroma of the organ. Within this stroma are the prostatic glands, composed of acini, lined with epithelium of the columnar variety, and opening into a series of ducts having their orifices in the floor of the urethra. The glandular alveoli frequently contain little coneretions of a substanee closely resembling amyloid, corpora amylacea, which often display a marked coneentric lamination (Fig. 214).

FIf. 214 .

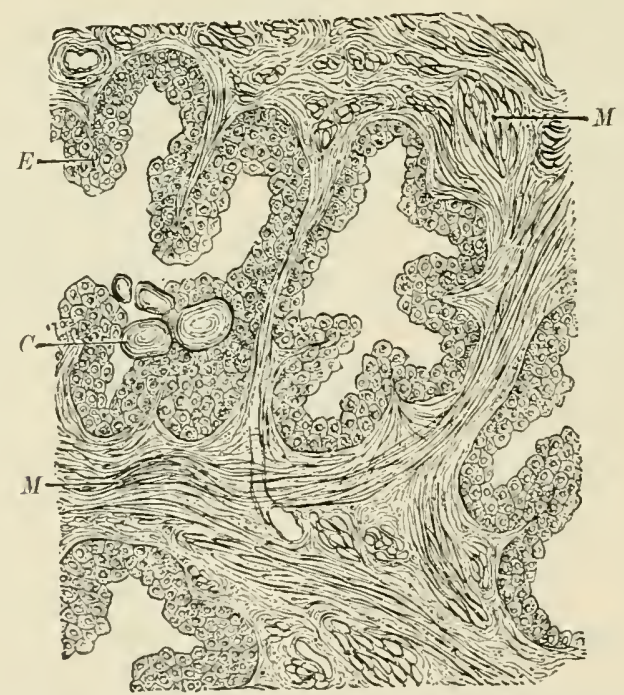

Section of the prostate. (Heitzmann.) Seetions of one acinus and portions of three others are ineluded in the figure. These are surrounded by fibrous tissue traversed by bundles of smooth muscular fibres. $E$, epithelial lining of the acini; $M, M$, smooth muscular tissuc; $C$, concretions of amyloid material, showing concentric lamination.

The two ejaculatory duets pass through the prostate to open intor the urethra in its course within that organ. A little behind their orifices is the verumontanum, containing ereetile tissue, which is 
supposed, during erection, to serve as a dam, preventing the entranee of semen into the bladder.

The ejaculatory ducts divide behind the prostate, one branch forming the dnct of the seminal vesicle, while the other becomes continuous with the vas deferens.

3. The Seminal Vesicles.-These are tubular sacs ending in blind extremities, with occasional sacenlar branches given off from their sides. They are lined with a mueous membrane eovered with columnar epithelium, resting upon areolar fibrous tissue. Outside of this is a muscular eoat eontaining internal eirenlar and extemal longitudinal fibres, and surromuled by an ill-defined fibrous coat that passes into the general areolar tissue of the region. The sominal vesicles sometimes eontain semen, for which they nay serve as a temporary reservoir, but they also secrete a fluid that is mixed with the semen at the time of ejaculation.

4. The Vasa Deferentia.-The vas deferens of each side resembles the seminal vesicle in structure. It is lined with columnar epithelium, bencath which is a layer of areolar fibrous tissue, resting upon the muscular coat. This is surrounded by fibrous tissue, becoming areolar as it blends with that of the neighboring parts. The muscular coat is thicker than that of the seminal vesicle, and is divisible into an inner layer of circular and an outer layer of longitudinal fibres. The mueons membrane, like that of the seminal vesicle, is thrown into folds, which are longitudinal throughout most of the course of the vas deferens, but are irregular in the sacenlated distal portions of the tube, giving the surface a reticulated or alveolar appearance.

5. The Epididymis.-The vas deferens of each side becomes continnows with the eanal of the epididymis, which is an enormously long tube, twenty feet, so convoluted and packed together as to ocenpy but little space. It is lined thronghout with columnar epithelium, continuous with that of the vas deferens; but, except for a short listance from the junction with the vas, the cells possess eilia of considerable length, which induce currents toward the vas deferens. The muscular coat of the latter is continued in the epididymis, but is very thin. Opening into the eanal of the epididymis are the vasa efferentia of the testis.

6. The Testis.-The testis is a compound tubular gland, of which the seeretion contains the spermatozoa. The latter are derived from certain of the cells lining the tubules, and contain within their 
structure a definite amount of chromatin and a centrosome. During the fertilization of the ovum this chromatin unites with a similar amount present in the eggr-cell, and thus forms a complete cell, the mucless of which contains equal amounts of chromatin from the male and female parents of the future offspring. We have seen (Chapter I.) that the nuclei of the cells throughout the body break "1p, during karyokinesis, into a definite and constant number of fragments, called "chromosomes," which split during metakinesis; one-half of each chromosome going to each of the daughter-nuclei. These chromosome-halves form a reticulum within the daughternuclei, and while in that form the ehromatin appears to increase in amount, so that by the time the cell divides again the full supply of chromatin is present in its nucleus. During the two cell-divisions which immediately precede and result in the formation of the spermatozoa and the matured egg this growth of the chromatin does not take place, and, as we shall presently see, each spermatozoon or matured ovmm contains but half of the chromosomes that are normally present in the somatic or general cells of the body. This "reduction of the chromatin" has been a matter of much study within the last few years, because of its probable bearing upon the problems of heredity. The fact of its oceurrence is strongly confirmatory of the idea that the chromatin is the carrier of hereditary characteristies, the fertilized ovum receiving equal shares from both parents.

The tubular glands of the testis are enclosed in a strong fibrons capsule, made up of interlacing bands of fibrous tissue. This becomes continuous, behind, with a mass of areolar tissue containing the vaseular supply of the organ and the epididymis, with the vasa efferentia opening into it. The fibrous capsule is ealled the "tunica albuginea." It is covered, except posteriorly, by the visceral portion of a serous membrane, the "tunica vaginalis." From the inner surface of the eapsule numerous bands and strands of fibrous tissue, trabeculie, traverse the glandular part of the organ, imperfectly dividing it into lobes, each of which contains several of the glandular or seminiferous tubes.

Upon the surfices of the trabecule and upon the inner surface of the capsule the dense fibrous tissue of those structures passes into a delicate areolar tissue, which gives support to the numerous small bloodvessels and abundant lymphaties distributed within the organ. This vaseular areolar tissue also penetrates between the seminiferous tubules, giving them support. In this region the 
interstitial tissue just mentioned contains large eytoplasmic cells of connective-tissme origin, which frequently contain globules of fat or granules of pigment, and in many instances, in man, have been observed to contain erystalloids of proteid nature. It has been sturmised that these eells may serve for the storage of mitriment required by the active proliferation of the cells that produce the spermatozoa within the seminiferons tubes (Fig. 215).

FIG. 215.

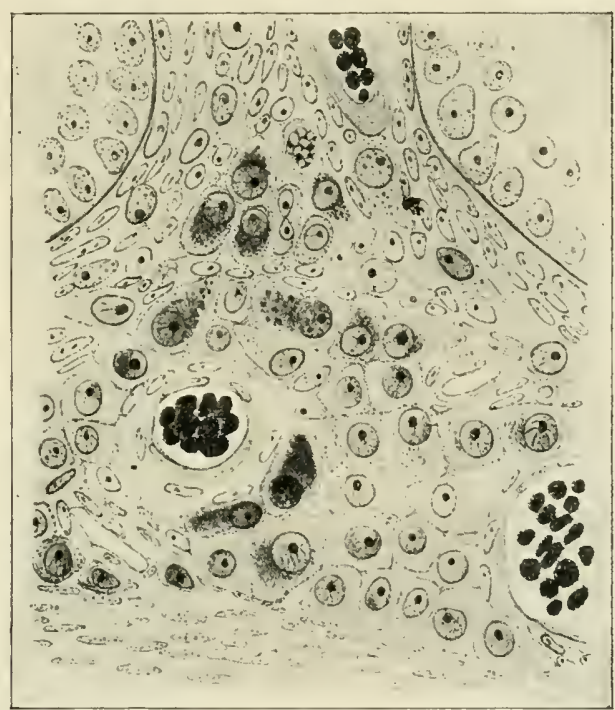

Interstitial tissue in the testis of the cat. (Plato.) Three bloodvessels are shown in either complete or partial section. Portions of two seminiferous tubules are represented at the upper corners. Between these structures is the interstitial tissue, containing large cytoplasmic cells. This tissue is rather more abundant in this instance than in the human subject.

Each seminiferous tube is provided with a basement-membrane, upon the inner surface of which are epithelial cells. These are divisible into three groms: first, a parietal layer of cells, the "spermatogonia," lying next to the basement-membrane; second, a layer of cells, oiten two or three deep, ealled the "spermatocytes," lying upon and derived from the spermatogonia ; third, the "spermatids," lying most centrally. The spermatids are derived from the spermatocytes, and are the elements from which the spermatozoa develop, one spermatozoon being formed from each spermatid.

The cells of the parietal layer, that containing the spermatogonia, are not all alike. At intervals certain cells, called "sustentacular" 
cells, or" the "cells of Sertoli," are differentiated from the others (Figs. 216-228). These sustentacular cells rest with a broad base, the

FIr: 216.

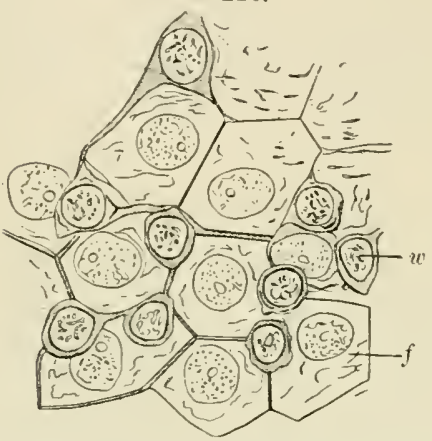

Superficial aspect of the parietal cells of the seminiferous tube: rat. (Ebner.) $f$, basal plates of the sustentacular cells (cells of sertoli), each containing a large vesicular nucleus, poor in chronatin, and a distinct nueleolis of eonsiderable size; $w$, spermatogonia resting upon the basal plates of the cells of sertoli. Only a few of the spermatogonia are represented.

FIG. 217.

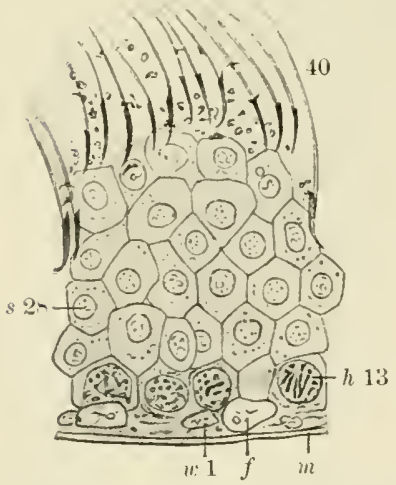

Fig. 218.

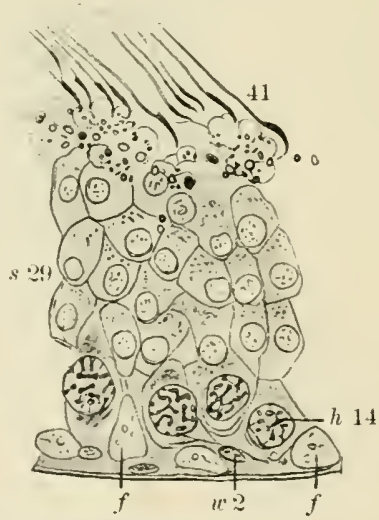

Sections from the testis of the rat, illustrating spermatogenesis. (Ebner.)

Figs. 217-22s,-w, spermatoronia ; $f$, sustentacular cells, or cells of Sertoli: $h$, spermatocytes: $s$, spermatids; $s p$, spermatids becoming transformed into spermatozoa: $w^{\prime}$ to $v 10$ traces the history of the suermatogonia from the resting eondition to that in which they have grown to become primary spermatocytes. During this proeess they move from the parictal layer into that covering it. $h 11$, a recently formed spermatocyte; $h 12$ to $h 20$, growth of the spermater 'rte: $h 21$, beginning of the division to form secondary spermatoevtes: $h 22$, its end: $h 23$, secondary spermatocyte, with chromatin in open spirem; $h 24$, division of the seeondary spermatocyte to form two spermatids; 825 , reeently formed spermatid : $s_{2} 6$ to s.ky, growtli of the spermatid. (By this time the preceding eroj of spermatozoa is fully developed and has heen diseharged into the lumen of the seminiferous tube.) 830 and sol, beginning transformation of the snermatids into snermatozoa. Their eytoplasm blends with that of the snstentaeular cell. sp32 to sp39 staces in the differentiation of the spermatozor; 4 , completel spermatozon ready to pass into the lumen of the tube. $w I$ (Fig. 227) and wII (Fig. 220) illustrate the division of the spermatogonia hefore they begin to revelup into spermatocytes. It is supposed that the sustentacular rells aid in the nourishment of the snermatids during tleir transformation into spermatozoa, and that after the discharce of the latter the extoplasmic process is retracted toward the basement-menbrane, bringing with it the globules of fat and eytoplasmie fragments of the spermatids represented by dark spots and small romd bodies in nearly all the figures. This retraction is taking place at $f$, Fig. 219. The cells of Sertoli do not appear to multiply; at least no karyokinetic figures have been observed in their nuclei. 
Fig. 219.

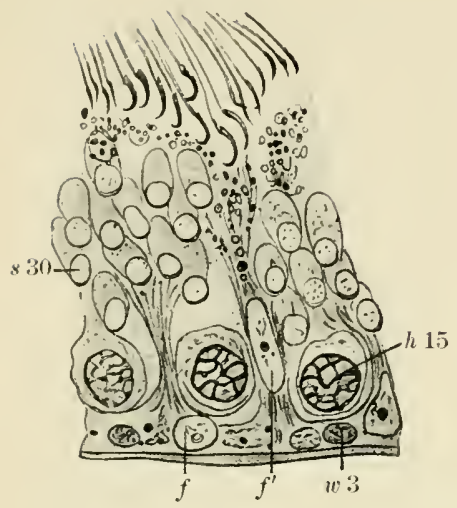

FIG. 2:1.

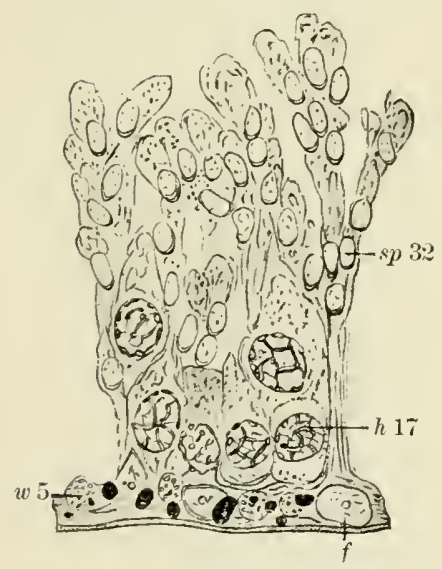

FIG, 223.

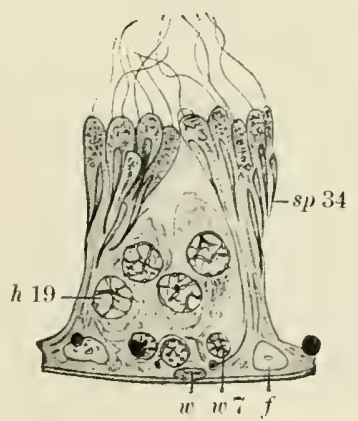

FIG. 220.

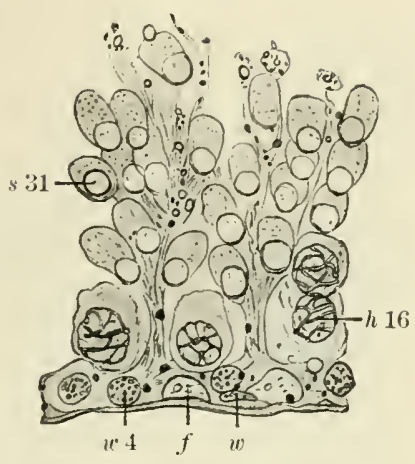

FIG. 22.

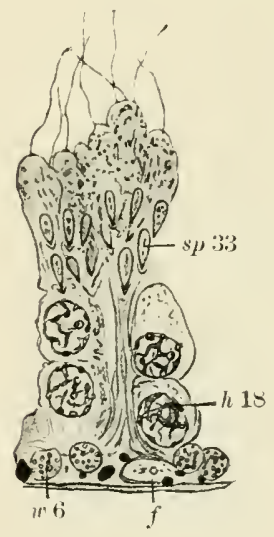

FIG. 224.

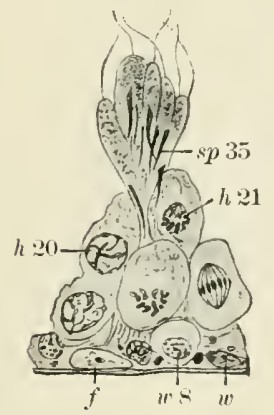


Fig. 225.

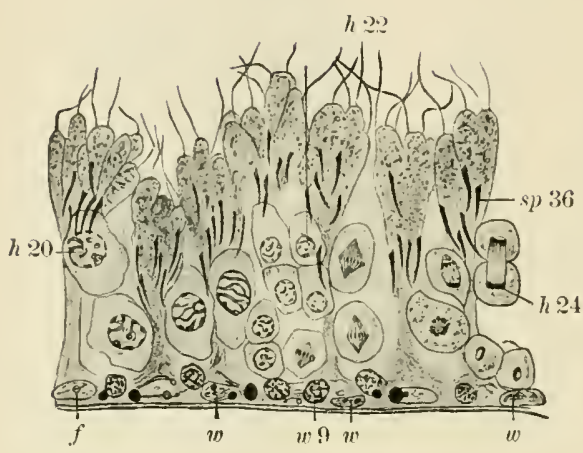

FIG. :2ะ.

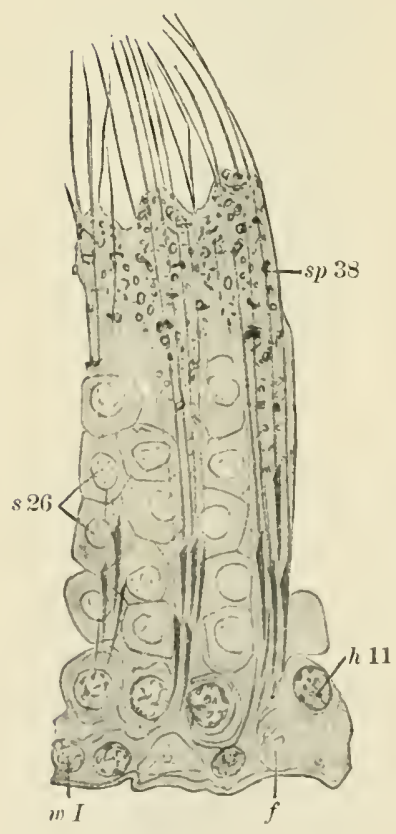

Fig. 2:26.

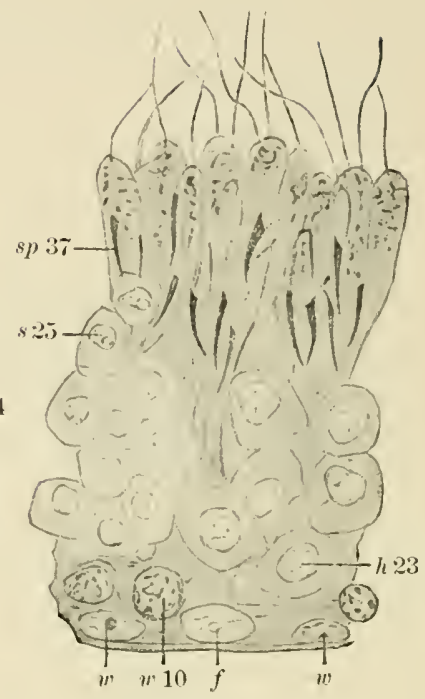

Fic. 2:28.

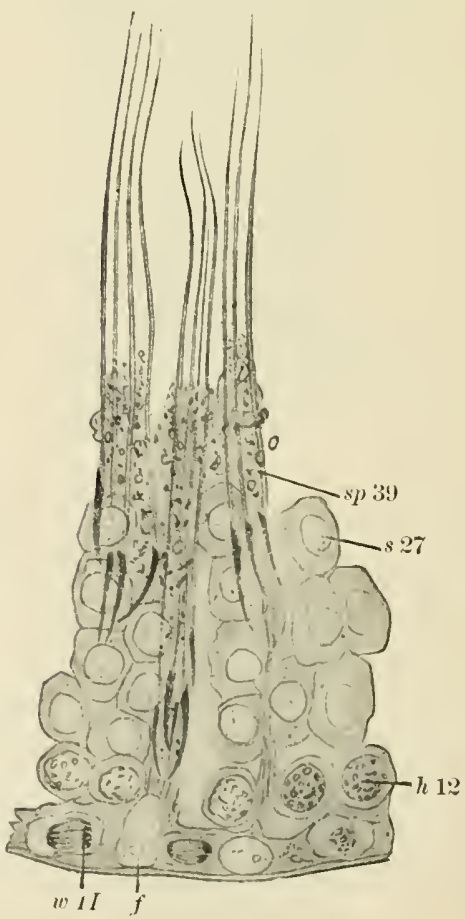


"basal plate," direetly upon the bascment-membrane, where the edges of the basal plates are in contact, forming a sort of bed with depressions in its upper surface, in which the spermatogonia find lorgement. The eells of Sertoli possess a thick eytoplasmic process, which extends toward the lumen of the tubule, and to which those spermatids which are developing into spermatozoa become attached. For this reason they are called sustentacular cells. Their muclei differ from those of the neighboring spermatogonia in being less rich in chromatin and in possessing a single and prominent nucleolus.

The appearances of the various cells enumerated depend upon the stage in their activity which happens to be under observation. The general course of development, ending in the formation of the spermatozor, is as follows: the spermatogonia, between the cells of Sertoli, multiply until quite a collection of such cells is produced. Each division is followed by a period of rest, during which the chromatin increases in amount. When the final stage of rest is at an enrl and the cells have attained their maturity, they constitute what are called the primary spermatocytes. These now divide, each forming two secondary spermatocytes, which in turn divide, withont an intermediate distinet resting-stage, to form two spermatids. Each primary spermatoeyte, therefore, gives rise to four spermatids. It is during the division of the secondlary spermatocytes that the reduction in chromatin, which was mentioned above, takes place (Figs. 217-228). Each spermatid receives, in arldition to its portion of chromatin, a single centrosome.

FIG. 229.

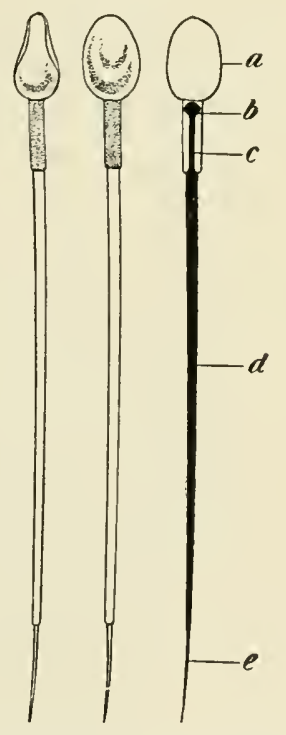

Human spermatozoa. (Böhm and Davidoff, after Retzius and Jensen.) The left figure represents the side view and the middle figure surface-view of a spermatozoon. $a$, head (nucleus); $b$, end-knob (centrosome?); $c$, middle piece; $d$, tail of flagella; $e$, end-piece. The thickness of $d$ may be owing to the presence of a sheath surrounding the actual flagella, which projects from the sheath at $e$.

The spermatozoon, then, is derived from a corpuscle, the spermatid, which contains all the essential organs of a cell, differing from the general cells of the body, the somatic cells, only in possessing half the 
usual number of chromosomes in its nuclens. It is unnecessary to pursue the chain of events through which the spermatid gives rise to the spermatozoon. It may suffice to state that the body of the latter consists of the chromatin of the nucleus; that the long cilium constituting the tail of the spermatozoon is developed from the cytoplasm ; and that the centrosome of the spermaticl is probably contained in the middle piece of the spermatozoon (Fig. 229). Even these conclusions are inferenees from studies of spermatogenesis in the lower animals, and not from direct studies of that process in man. The latter undoubtedly conforms very elosely to the former in all essential details.

To return to the histology of the testis : the epithelial cells of the seminiferous tubules rest upon a basement-membranc, which is divis-

FIG. 230.

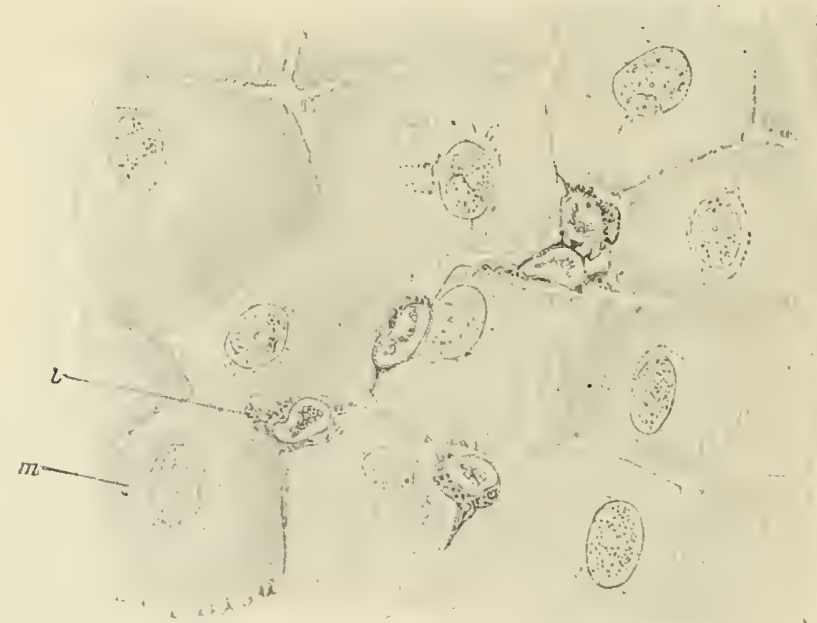

Basement-membrane from seminiferous tube of the rat. (Ebner.) $m$, endothelial cells composing the external layer; $l$, cells, presumably leueocytes, interealated between the endothelial eells. The faint striations upon the endothelial cells represent wrinkles in the homogeneous membrane forming the inner surfice of the basement-membrane; the wrinkling is probably due to a slight shrinkage of the endothelium.

ible into two layers: first, an internal, extremely delicate, homogeneons membrane, upon which the epithelial cells rest; and, seeond, a layer of entothelial rells (Fig. 2:30). The latter may bomel, at least in places, the lymphatic spaces, which are abundant in the interstitial tissue of the testis.

Toward the back of the testis the seminiferous tubules unite 
with each other and open into a number of straight ducts of smaller liameter, called the "vasa recta." These are lined with a cubical epithelimm resting upon an extension of the basementmentrane of the seminiferons tubes, and, in turn, open into a retienlum of tubules of larger diameter, situated in the mass of areolar tissue at the posterior aspect of the testis. This reticulum is called the "rete vasculosum," and the tubules composing it are lined with a low epithelimm, apparently resting upon the surrounding fibrous tissue, without an intermediate basenent-membrane. These tubes permit an accmmulation of semen before it enters the vasa efferentia.

The vasa efferentia have a peculiar epithelial lining, which may be regarded as transitional between the cubical epithelium of the vasa recta and rete and the ciliated columnar variety lining the epididymis. It consists of alternating groups of cubical and ciliated columnar epithelial cells (Fig. 231).

FIG. 231.

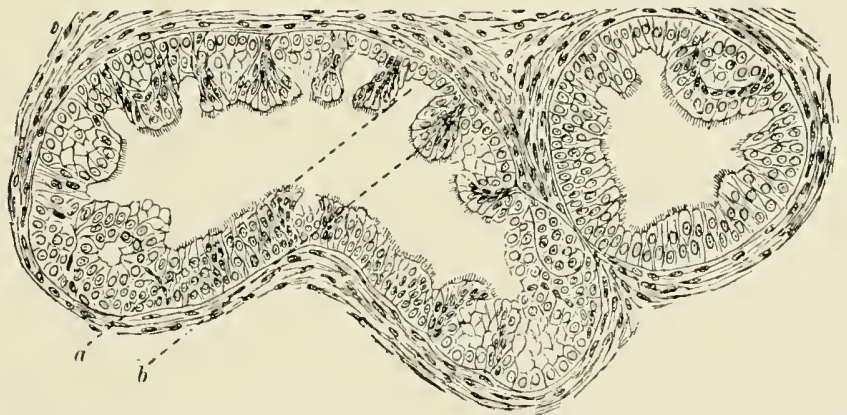

Section of vasa efferentia from human testis. (Böhm and Davidoff.) a, cubical or secretory epithelium; $b$, columnar ciliated epithelium, with deeper pyramidal cells beneath those that bear the cilia. This form of ciliated epithelium corresponds to that found in the eprdidymis where the cubical epithelium is absent.

The vasa efferentia, as already stated, open into the canal of the epididymis, through which their contents rach the vas deferens. The walls of the efferent tubes possess a layer of encircling smooth muscular fibres, which are reinforeed in the epididymis by an additional external layer of longitudinal fibres.

The nerves supplied to the testis are destitute of ganglia, and are distributed to the vessels and surfaces of the seminiferous tubules. No terminations have been traced to the epithelial lining of those tubules. 


\section{CHAPTER XVIII.}

\section{THE CENTRAL NERVOU'S SYSTEM.}

The functional part, or parenchyma, of the central nervous system is composed of ganglion-eells with their processes. Some of these processes are of cytoplasmic nature, and, as explained in the chapter on the elementary tissues, are ealled the protoplasmic processes. From each ganglion-cell at least one process is given off which differs from the protoplasmic processes, and is ealled the "axis-cylinder proecss." This in most eases becomes the axiscylinder of a nerve-fibre, and may be invested with a medullary sheath and neurilemma at some point near or at some distance from its exit from the cell.

It will be convenient, for the brief decription of the central nerrous system to which this chapter must be restricted, to adopt a special terminology for the different portions of the ganglion-cell and its processes, as follows: the term ganglion-cell will be restricted to the mucleus and the cytoplasm surrounding it ; the protoplasmic processes will be called the demlrites, and their terminations the teledendites. The axis-cylinder process will be termed the neurite; the delicate branches it may give off in its course, the collaterals; and the terminal filaments of the main trunk, collectively the teleneurites. The eell, with its processes and their terminations, will collectively constitute at nenrom.

A complete nemron, then, consists of (1) certain teledendrites, which unite to form one or more dendrites eonnecting them with the ganglion-cell ; (2) the eell itself; and (3) one or more nenrites, which may give off collaterals and finally terminate in telenenrites (Fig. 232).

At the present time these neurons are believed to be without actual connection with each other, but to convey nervous stimuli by contact. The course of the nervous impulses is from the teledendrites to the nerve-eell, and thence, by way of the neurite, to the teleneurites, whenee it is communicated, without a direct structural union, to the next tissue-element in the chain of nervous transmission. Those neurites which carry stimuli from the nerve-centres. 
to the periphery, centrifugal impulses, form the axis-eyliuders of some of the nerves. 'The axis-cylinders of those nerves which convey impulses from the periphery toward the nervous centres,

FIG. 2:3:.

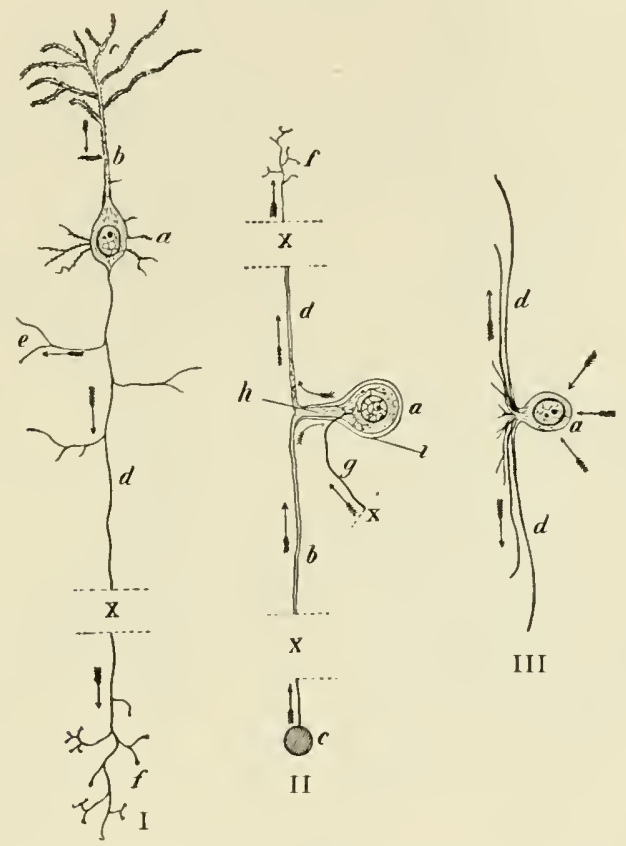

Sketeh illustrating the eomposition of neurons. I, a neuron transmitting eentrifugal impulses. II, a neuron receiving and transmitting eentripetal impulses. 11I, a neuron, the function of which is supposed to be the distribution of inpulses within the nervecentre in which it is situated. $\alpha$, ganglion-cell; $b$, dendrite; $c$, teledendrites; $d$, neurite ; $\boldsymbol{e}$, eollaterals; $f$, teleneurites. In II the body $c$ represents some sensory organ imparting nervous impulses to the teledendrites of a sensory nerve. The nervous filament $g$ is a neurite, presumably derived from the sympathetic nervous system, leading to teleneurites applied to a ganglion-ell, $a$, of a posterior spinal ganglion. The portion $h$ of the "nerve" springing from that eell is regarded as a portion of the eell itself. In the embryonie condition the dendrite and neurite both spring directly and separately from the body of the eell, the portion $h$ being a subsequent development. $i$, endothelia] envelope surrounding the ganglion-cell. III represents a ganglion-eell, a parently devoid of distinet dendrites, but having numerous proeesses that at first appear protoplasmie, but soon assume the characters of neurites. These cells are found in the retina and olfactory hulb, and have heen termed spongioblasts, eellulas amacrinas, and pararetieular cells. It is thought that nervous stimuli are received directly by the cytoplasm of the cell, without the intermediation of dendrites. $x$ represents the omission of a portion of a fibre. The arrows indicate the direetions taken by nerrous impulses.

centripetal stimuli, may be the dendrites connected with ganglioncells in or near those centres; $e . g$., in the posterior root-ganglia of the spinal nerves, or they may be the neurites springing from 
peripheral ganglion-cells, ats is exemplified in many, if not all, of the organs of special sense.

\section{THE SPINAL CORD.}

The axis of the spinal cord is composed of a column of gray matter containing numerons ganglion-cells and nervous filaments held in position by a cement-substance, neuroglia-cells, the fibrous prolongation of the ependyma cells lining the central canal, and a little fibrous tissue accompanying the vessels derived from the pia mater.
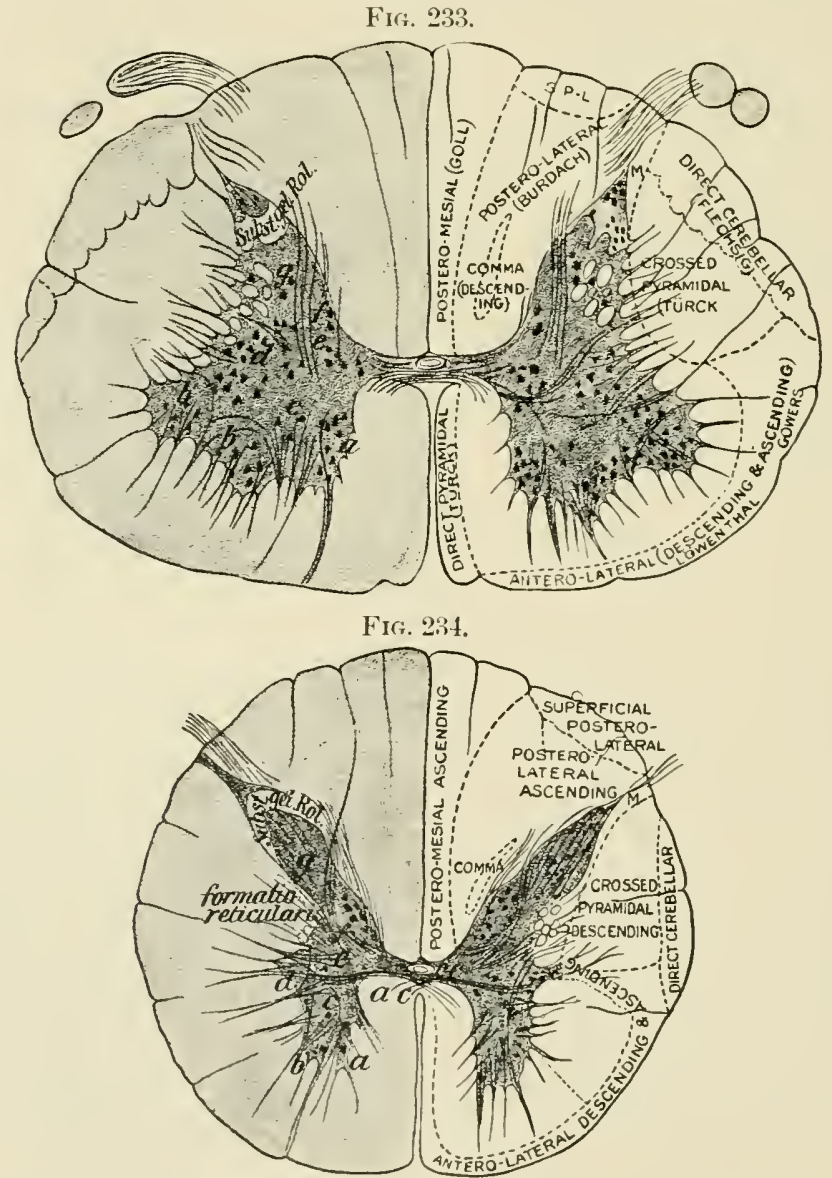

FIGS. 233 and 234.-Transverse sections of human spinal cord. (schäfer.)

Fig. 233, from the lower cervical region; Fig. 234, from the middle dorsal region. $a, b, c$, groups of ganglion-cells in the anterior horn; $d$, cells of the lateral horn: $e$, middle group of cells; $f$, cells of Clarke's column: $g$, cells of posterior horn; $c, c$, central canal, $u, c$, anterior commissure of white matter. 


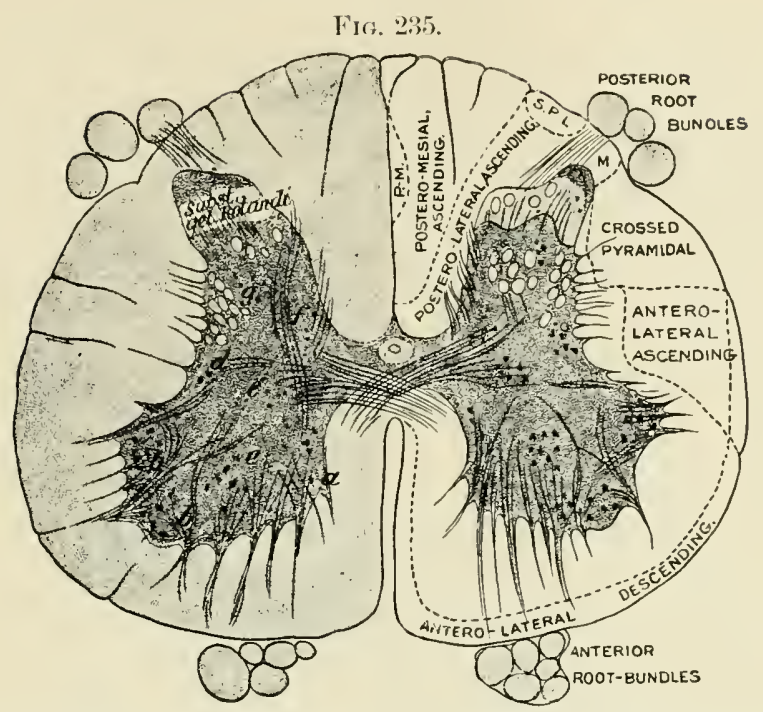

Transverse section of human spinal cord, from the middle lumbar region. (Schäfer.) $a b, c$, groups of ganglion-cells in the anterior horn; $d$, cells of the lateral horn; $e$, midile group of cells; $f$, cells of Clarke's column; $g$, cells of posterior horn ; $c$. $c$, central canal; $a, c$, anterior commissure of white matter.

In cross-section this column of gray matter presents a transverse central portion, the gray commissure, near the middle of which is the central canal. At each side this gray commissure blencls with masses of gray matter, occupying nearly the centre of each lateral half of the cord and having a general crescentic form. The ends of these crescentic masses form the anterior and posterior comua of the gray matter, from which the anterior and posterior roots of the spinal nerves proceed. The anterior cornua are larger than the posterior and contain larger ganglion-cells.

Surrounding the colımn of gray matter everywhere, except at the bottom of the posterior median fissure of the cord, and the interruptions formed by the nerve-roots in their exit from the gray matter, is a layer of white matter, formed of medullated nervefibres running parallel with the axis of the cord and held together by neuroglia and delicate vascularized fibrous bands proceeding from the deep surface of the pia mater.

The white matter of the cord has been divided into a number of colnmms, for the most part indistinguishable through structural differences, but each containing fibres that play similar functional rôles. These columns, with their names, are indicated in Figs. 233, 234, and 235. The columns of Goll and Burdach, forming the posterior 
columm of the white matter, between the posterior cornua and the posterior median fissure, conduct, for the most part, centripetal impulses. Impulses having the same upward direction are also eonveyed by the direct cerebellar tract and the tract of (xowers in the lateral column of the white natter. Centrifugal impulses, motor stimuli, are conveyed by the fibres in the direct pyramidal tract of the anterior eolumn and by those of the erossed pyramidal

Fla. 236.

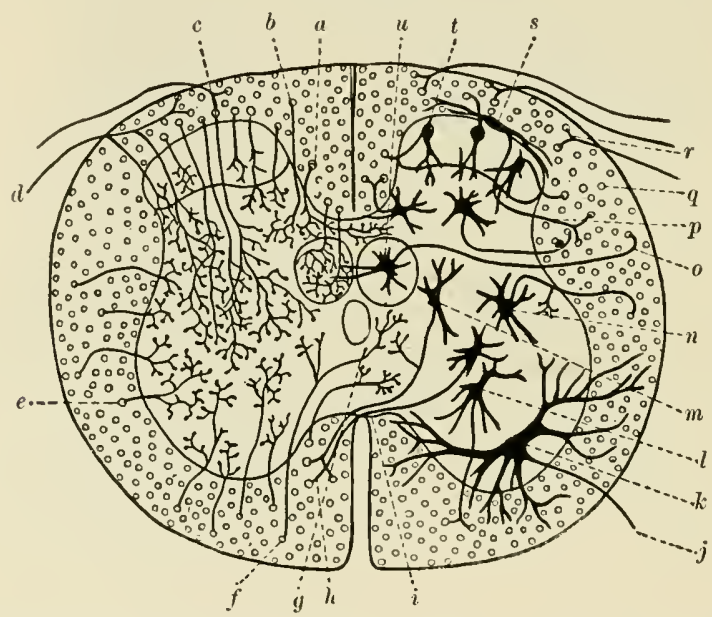

Diagram of spinal cord, illustrating the associations of its various nervous elements. (R. $y$ Cajal.) $a$, collateral from Goll's tract, entering into the formation of the posterior commissure; $b$, collateral to the posterior horn; $c$, collateral to the formatio reticularis and the anterior horn; $d$, posterior nerve neurite, with its collaterals; $e$, collaterals from the lateral column: $f$, collaterals to the anterior comınissure: $g$, central canal: $h$, neurite in the crossed nyramidal tract from the commissure-cell of the opposite side; $i$, its course in the commissure; $j$, neurite from a large motor cell in the anterior horn $k$; $l$, cell of the anterior horn, giving off a neurite dividing into an ascending and a descending liranch (compare Fig. $239, D) ; m$, commissure-cell; $n$, cell giving off a collateral within the gray matter; $o$, neurite of the cell $u$, in Clarke's column: $p$, neurite from the marginal cell $s$, of the substance of Rolando; $q$, cross-section of an axis-cylinder (neurite) in the white substance of the cord ; $r$, division of a posterior nerve-fibre (neurite) into ascending and descending branches; $t$, small cell in the sulstance of Rolando. Aside from the cells indicated in the figure, the gray matter contains some that give off neurites which divide into two or three branches while in the gray matter, the branches going to different columns of white matter. There are also cells with very short neurites, which terminate in teleneurites within the gray matter, and probably distribute nervous impulses for short longitudinal distances.

tract in the lateral column. The tracts hitherto considered contain fibres that are eontimed into the higher nerve-centres of the brain and cerebellum, to or from which they convey nervous impulses. But the spinal cord is not merely a collection of such transmitting 
fibres. It is also a nerve-centre of complex constitution, in which neurons terminate in teleneurites or arise in teledendrites.

Some of the neurons within the cord are confined to its substance, and constitute nervous connections between the different parts at various levels. These may be termed longitudinal commissmral neurons, or association-fibres. Portions of such neurons are represented in the diagram of a cross-section of the cord (Fig. 236), which also contains representations of some of the neurites in the posterior spinal nerve-roots, with their collaterals ending in teleneurites within the gray matter $(d)$. On the right side of the figure, the nerve-cells, with their dendrites and the beginning of the neurites, are shown. On the lefit side the neurites connceted with cells at another level are shown, re-entering the gray matter, where they terminate in teleneurites. In studying this figure it must be borne in mind that the teledendrites of the nemrons on the right are in close relations with the teleneurites of other neurons, and that the telenenrites represented on the left are in close relations with the teledendrites of other neurons. These association-neurons are, therefore, merely links in chains of communicating neurons. They are again represented in Fig. 239, $D$ and $E$.

Aside from these association-neurites, the gray matter of the cord receives innmmerable collaterals from the nemites forming the axis-cylinders of the nerves in the various columns of the white matter. These collaterals terminate in teleneurites, which are in close relations with the teledendrites of the neurons arising in the cord. The distribution of these collaterals is represented in Fig. 237. The collaterals from the anterior column enter the anterior horn of the gray matter, where they are chicfly distributed about the large ganglion-cells in the antero-lateral portion of its substance (Fig. 233, b; Fig. 236, j), but mity also extend to other parts of the gray matter. 'The collaterals from the fibres in the lateral columus of the white matter are most numerous near the posterior horn, which they enter, many of them passing through the gray matter behind the central canal and forming a part of the posterior or gray commissure of the cord (Fig. 2:37, I). The collaterals from the posterior column are divisible into four groups: first, those which are given off in the lateral portion of that column (Fig. 237, G), and are distributed in the onter portion of the posterior horn and in the substance of Rolando (Fig. 2:37, I) ; second, those which end in Clarke's column (Fig. 237, J); third, those 
which arise chiefly in the column of Goll, pass through the substance of Rolando, and then form an expanding bundle distributed in the anterior horn of the gray matter, where they are in association with the dendrites of the motor cells in that region (these fibres form the reflex bundle of Kölliker, Fig. 2:37, H); fourth, collaterals springing from fibres in the posterior column, passing

F1G. :37.

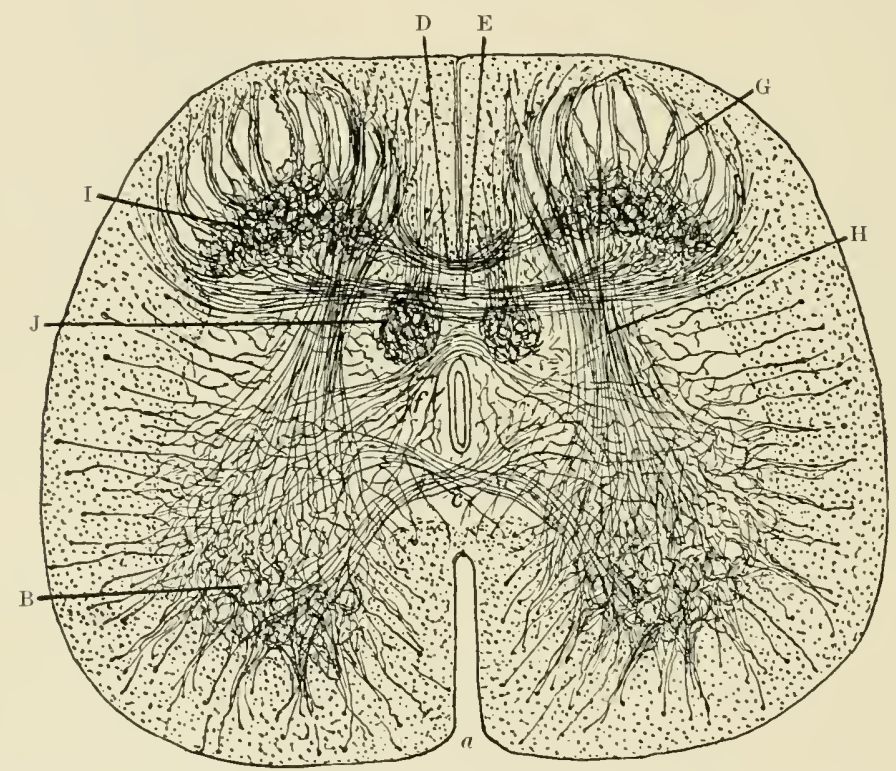

Cross-section of the spinal cord of a newborn ehild, showing the distribution within the gray matter of the collaterals from the neurites of the white matter. (R. y Cajal.) $a$, anterior fissure; B, pericellular branches of the collaterals from the anterior column; $C$, collaterals of the anterior commissure; D, posterior bundle of collaterals in the posterior commissure; $E$, middle bundle of the posterior commissure; $f$, anterior bundle; $G$, collaterals from the posterior column: II, senso-motory collaterals from the posterior column; $\mathrm{I}$, pericellular terminations of eollaterals in the posterior horn ; J, collateral terminations in the column of Clarke.

through the posterior commisoure of gray matter and ending in the substance of Rolando of the opposite side (Fig. 237, D).

The reflex collaterals arising in the posterior column are shown in Fig. 238, where their telenenrites are in elose relations with the teledlendrites of the motor cells $e$.

The centripetal or sensory neurites of the posterior spinal nerveroots spring from the ganglion-cells of the spinal gauglia. When they have entererl the white matter of the spinal cord they divide 
into two branches (Fig. 296, ${ }^{\circ}$ ). One of these ascends in the white substance and the other descends. Both branches give off numerous collaterals, which penetrate the gray matter, ending in teleneurites associated with the teledendrites of the cells in both the anterior and the posterior horns, and the column of Clarke. The main branches of the sensory neurite also enter the gray matter, after

F19. 238.

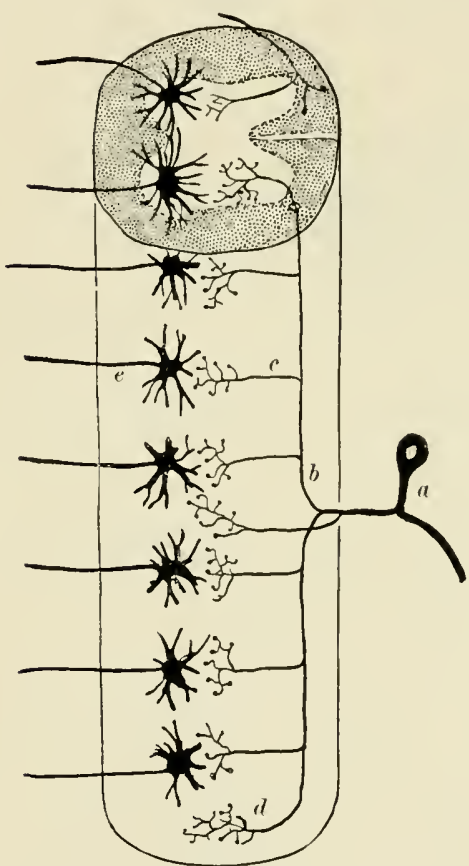

FIG. 239.

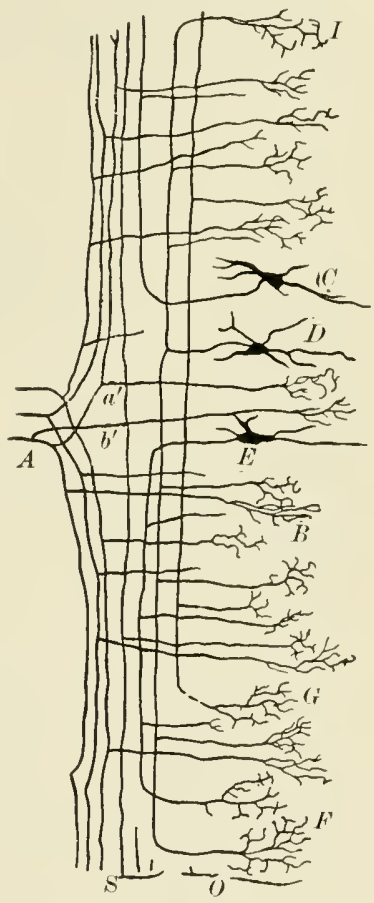

Fig. 238.-Diagram of the senso-motory reflex collaterals in the eord. (R. y Cajal.) $a$, ganglion-cell of the posterior nerve-root; $b$, division of its neurite into aseending and deseending branches; $c$, collaterals to anterior horn; $d$, terminal teleneurites in the posterior horn; $e$, motor cell of the anterior horn, with its processes.

Fig. 239.-Longitudinal section of a part of the spinal cord, including a posterior nerre-root. Semidiagrammatic. (R. y Cajal.) $A$, posterior nerve-root; $S$, white substance of the eord ; $O$, gray matter; $B$, collateral teleneurites in the gray matter; $C$, cell with a single ascending neurite: $D$, cell with bifureating neurite, terminating at $F$ and $I ; E$, eell with a single deseending neurite; $F, G$, terminal teleneurites; $a^{\prime}$, collateral from a branch of the posterior root-neurite; $b^{\prime}$, collateral from the main neurite before its bifurcation.

following the posterior column for a short distance, and end in teleneurites among the cells of the posterior horn and the substance of Rolando. The collaterals which pass to the anterior horns (Fig. 237, H, and Fig. 238, c) have to do with the origin of reflex cen- 
trifugal impulses emanating from the motor cells in that region (Fig. 238, e, and Fig. 2:36, j). The further transmission of these centripetal stimuli toward the higher nerve-centres of the brain probably takes place: first, through the cells in the posterior horns, the neurites from which pass into the lateral column: and there ascend the cord; second, through the cells of Clarke's column, which also send neurites into the lateral column, where they enter the direet eerebellar tract (Fig. 236, o; see also Fig. 239). In addition to these centripetal or sensory neurites, the posterior nerveroots contain a few centrifugal neurites.

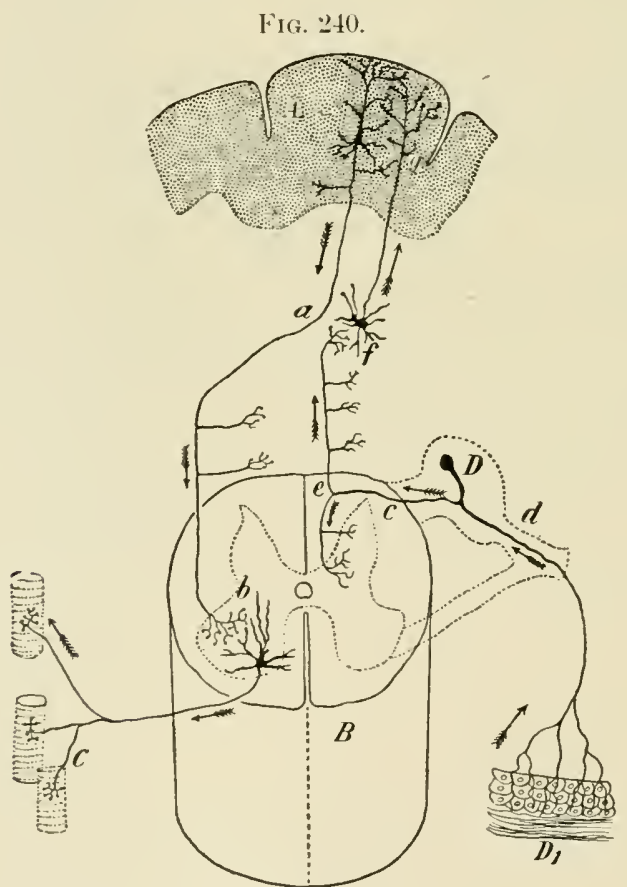

Diagram of a sensory and a motor tract. (K. y Cajal.) A, psycho-motor region in cerebral cortex; $B$, spinal cord ; $C$, voluntary muscle; $D$, spinal ganglion; $D^{\prime}$, skin ; $a$, axis-cylinder of a neuron extending from the cerebral cortex to the anterior horn of the spinal cord, where the terminal teleneurites are in relations with the teledendrites of the motor cell at $b$. The sensory stimulus arising in the shin, $D^{\prime}$, is transmitted by the neuron dInce to $f$, where it is communicated to the neuron $f g$. The point $f$ may be in the cord or in the medulla oblongata.

In order to understand the origin of the anterior spinal nerveroots we must first conider the conrse of the centrifugal neurites in the pyramidal tract. (Fig. 23:3, 234, 235). These enter the gray matter and end in teleneurites, which are associated with the tele- 
dendrites of the cells in the anterior horn, especially those which give off neurites to the anterior roots of the spinal nerves (Fig. $236, j)$.

The foregoing details may be summarized by means of the accompanying diagram (Fig. 240), in which the eourse of a nervous stimnlus is traced from the organ of sense in, e.g., the skin, to the cortex of the eerebrum, where it is translated into a nervous inpulse, the course of which is traced to the motor plates of the voluntary muscles. The reflex mechanism which might at the same time be set into operation is not represented in the diagram, but will be sufficiently obvious from an inspection of Fig. 238. It will be noticed in Fig. 240 that both the sensory stimulus and the motor impulse are obliged to pass through at least two neurons before they reach the ends of their journeys. But the nervons currents are by no means entirely confined to the course marked by the arrows. Impulses may be transmitted in an incaleulable number of delicate tracts through the collaterals given off from the neurites within the central nervous system, some of which are indicated in the diagram, and all of which end in telenemrites associated with the teledendrites of, perhaps, several neurons. One of these collateral traets las already been considered, namely the senso-motory reflexes illustrated in Fig. 238.

\section{THE CEREBELLUM.}

The cerebellum is subdivided into a number of laminæ by deep primary and shallow secondary fissures. The gray matter of the organ oceupies the surfaces of these laminæ, while their central portions are composed of white matter. The gray matter may be divided into two layers: an external or superficial "molecular layer" and an inner "granular layer" (Figs. 241 and 242).

The molecular layer contains two forms of nerve-eells: first, the large cells of Purkinje; second, small stellate cells.

The cells of Purkinje have large, oval, or pear-shaped bodies lying at the deep margin of the molecular layer. Their dendrites form an intricate arborescent system of branches extending peripherally to the surface of the gray matter, and give off innumerable small teledendrites throughout their course. All these branches lie in one place, perpendicular to the long axis of the lamina in which they are situated, and the teledendrites come into relations with certain longitudinal neurites springing from the cells of the granular layer, 
to be presently described. The neurites of the cells of Purkinje extend through the gramular layer into the white matter and soon acquire medullary sheaths (Fig. 241, o); but before they leave the gramular layer they give off collaterals, which re-ascend into the molecular layer, where their teleneurites are in relations with the

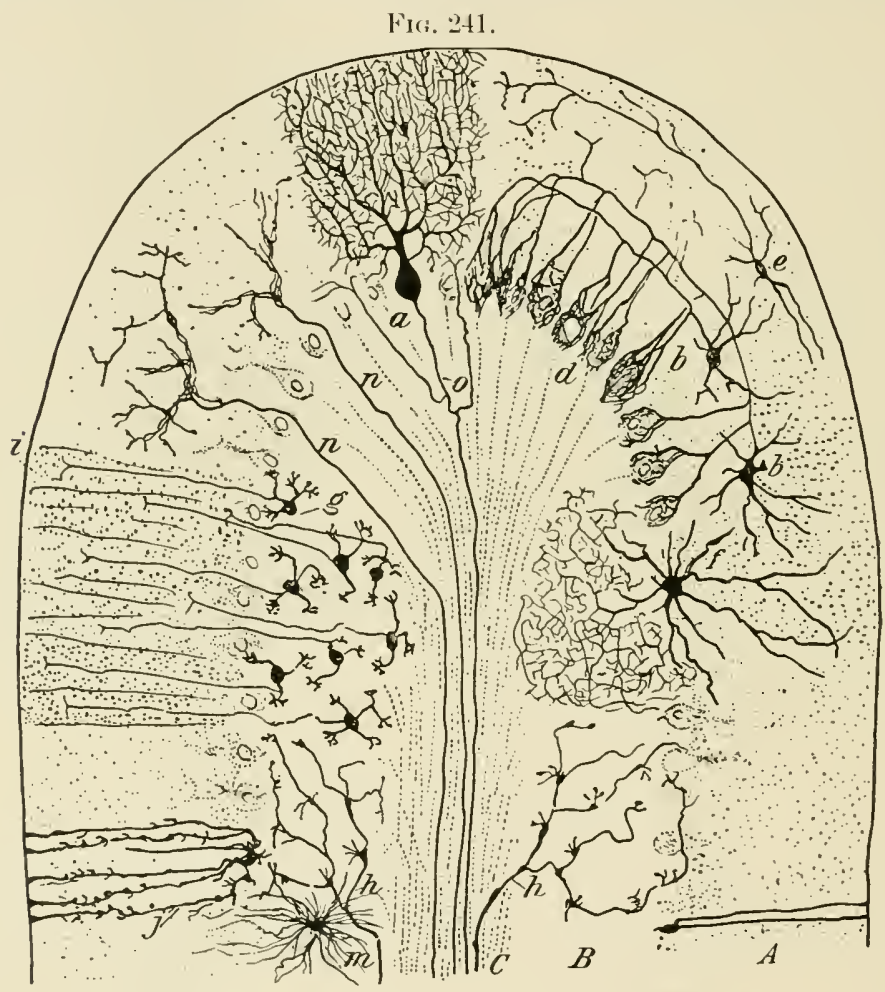

Section of a eerebellar lamina perpendicular to its axis. (R. y Cajal.) A, molecular layer of the gray matter; $B$, granular layer; $C$, white substance; $a$, cell of Purkinje; $o$, its neurite, giving off two reeurrent collaterals; $b, b$, stellate cells of the molecular layer; $d$, basket-like distribution of the teleneurites of one of their eollaterals around the body of a cell of Purkinje; $e$, superficial stellate cell, which does not appear to come into relations with the bodies of the cells of Purkinje, but must lie close to their dendrites; $f$, large stellate cell of the granular layer; $g$, small stellate eell of the granular layer; $h$, centripetal neurite of a "moss" fibre; $n$, centripetal neurite distributed in the molecular layer; $j, m$, neuroglia-cells. The arborescent dendrites of only one of the cells of Purkinje are represented in the figure. Were those of the neighboring eells also represented, the molecular layer of the gray matter would display an enormously complex interdigitation of such filaments.

tcledendrites of neighboring cells of Purkinje. These collaterals are believed to occasion a certain co-ordination in the action of those cells of Purkinje which are near each other.

The stellate cells of the molecular layer (Fig. 241, b,e) pos- 
sess nemites, which lie in the same plane with the arborescent dendrites of the cells of Purkinje, and send collaterals to end in a basket-work of teleneurites applied to the bodies of the cells of Purkinje. The terminal teleneurites of these stellate cells also end in the same situation. Other smaller collaterals extend toward the surface of the cerebellar lamina.

The granular layer of the gray matter also contains two varieties of nerve-cells: the "small stellate cells," which are most numerous, and the "large stellate cells."

FIG. 242.

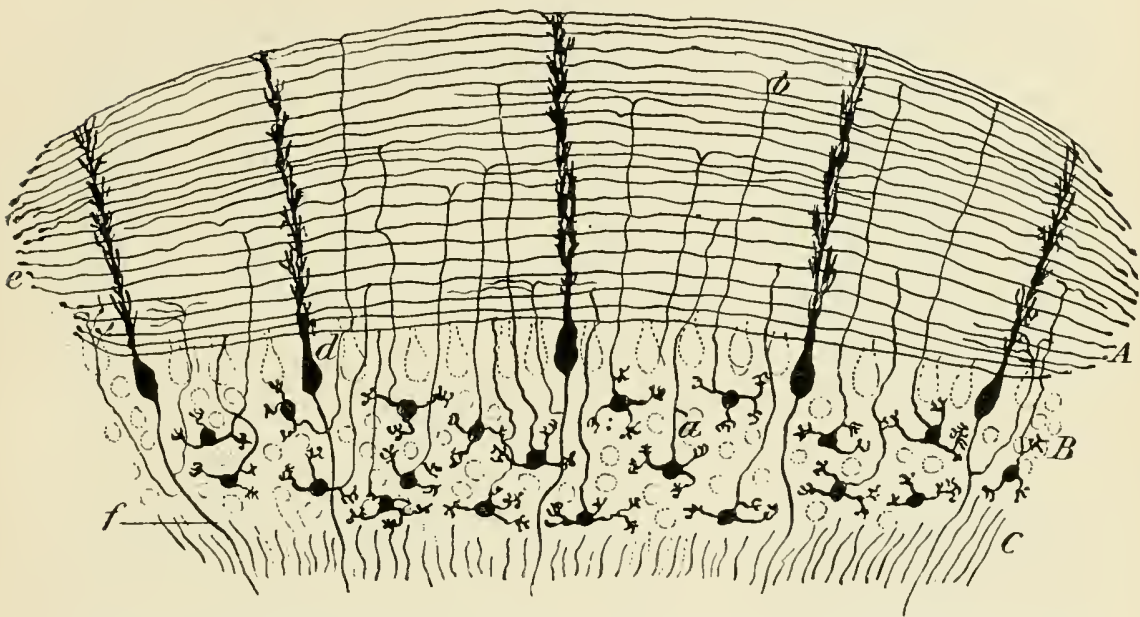

Section of a cerebellar lamina parallel to its axis. (R. y Cajal.) A, molecular layer of the gray matter; $I$, granular layer; $C$, white substance; $\alpha$, small stellate cell of the granular layer, from which a neurite enters the molecular layer, where it bifurcates, sending branches throughout the length of the lamina; $b$, bifurcation of one of these neurites ; $e$, slightly bulbous termination of one of the neuritic branches; $d$, body of a cell of Purkinje seen in profile; $f$, neurite of a cell of Purkinje.

The small stellate cells (Fig. 241, $g$, and Fig. 242, $a$ ) are scattered throughout the granular layer, and it is owing to the abundance of their nuclei that this layer has received that name. 'Their dendrites are few in number and short, but their neurites are very long. They extend perpendicularly into the molecular layer, where they bifurcate, the branches lying parallel with the axis of the cercbellar lamina and its surface. These fibres appear to run the whole length of the lamina, and to come in contact with the teledendrites of the cells of Purkinje, to the planes of which they run perpendicularly. They are thought to coördinate the action of a long series of the cells of Purkinje. 
The large stellate cells of the gramular layer lie near its external margin, whence they send their dendrites into a large area of the molecular layer, while their neurites are distributed in the granular layer, where they must come into relations with the dendrites of the small stellate cells (Fig. 241, $f$ ).

The distribution of the cells and their processes in the cerebellum indieates a very complex interchange of nervous impulses and an extraordinary coördination in the action of the various neurons.

This complication is still further increased by the presence of centripetal neurites, which enter the cerebellum through the white matter and are distributed in the gray matter. These are of two sorts: first, nemrites which penetrate the granular layer and are distributed among the proximal dendrites of the eells of Purkinje (Fig. 241,n); second, neurites, called " moss" fibres, which are distributed among the cells of the granular layer. The teleneurites of these fibres have a mossy appearanee, whence the name (Fig. 241, h). The origin of these centripetal neurites is not known, but it is surmised that the "moss" fibres may enter the cerebelium through the direct eerebellar tracts of the cord.

\section{THE CEREBRUM.}

The gray matter of the cerebral cortex has been divided into four layers: first, an external molecular layer; second, the layer of small pyramidal cells; third, the layer of large pyramidal cells; and, fourth, an internal layer of irregular or stellate cells. Of these layers, the second and third are not clearly distinguishable from each other (Fig. 243).

The molecular layer contains three sorts of nerve-cells, two of which are closely related to each other, differing only in the form of the cell-bodies, which are small in both varieties (Fig. 244, 1 , $B$, and $C$ ); while the cell-bodies of the third variety are large and polygonal (Fig. 244, D). The small cells $(A, B, C$, Fig. 244) possess two or three tapering processes, which at first resemble protoplasmic processes, but soon assume the eharacters of neurites or axiscylinders. These neurons, then, resemble the type depieted in Fig. 232 , III. Their neurites run parallel to the surface of the convolution in which they are situated, sending off numerous perpendieular collaterals, and finally end in telencurites within the molecular layer. The collateral and terninal teleneurites are probably in relations with the dendrites of the pyramidal cells of the under- 
lying layers, which form arborescent expansions in the molecular layer, similar to those of the cells of Purkinje in the cerebellum, extending to the surface of the gray matter.

The large stellate cells of the moleeular layer (Fig. 244, I) send their dendrites in various directions in to the molecular layer and the layer of small pyramidal cells lying beneath it. The neurite is distributed in the molecular and upper portions of the underlying layers, but is never extended into the white matter. The dendrites of these cells come into relations with the neurites of the other cells of this layer and with those that proceed upward from some of the eells in the deeper layers.

The small spindle- and stellate cells ( $A, B, C$, Fig. 244) are considered to be the autochthonous cells of the cerebral cortex-i.e., the cells of the brain in which the highest order of nervous impulses find their origin. The small spindle-shaped cells, with their peculiar neurites, are extremely abundant and fill the molecular layer with a mass of interwoven filaments.

The second and third layers of the cerebral gray matter are characterized by the presence of pyramidal nervecells of various sizes, the smaller being relatively more abundant in the second FIG. 243.

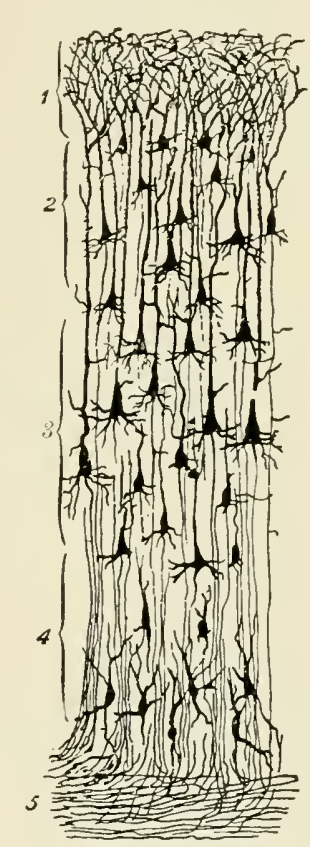

Vertical section of the cerebral cortex, showing its layers. (R. y Cajal.) 1, molecular layer; 2 , layer of the small pyramidal cells; $s$, layer of the large pyramidal cells; 4, layer of polymor. phic cells; 5 , white matter. layer and the larger in the third layer. From the apex of the pyramidal cell a stout, "primordial" dendrite passes vertically into the molecular layer, where, as well as during its course to the molecular layer, it gives off numerous branches, and finally ends in a brush of teledendrites extending to the surface of the gray matter (Fig. 245, $A, B)$. Other and shorter dendrites are given off from the body of the cell, which ramify and end in the second, third, or fourth layer of the gray matter. The neurites from the bases of the pyramidal cells pass vertically downward into the white substance, where they may bifurcate, giving axis-cylinders to two nerve-fibres. While within 
FIG. 244

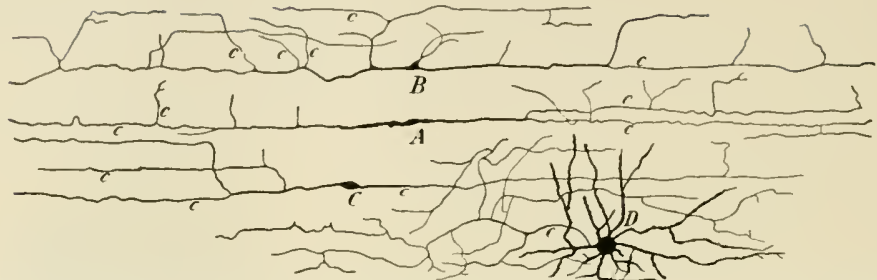

Cells of the molecular layer of the cerebral cortex. (R. y Cajal.) $A, C$, small spindle-shaped cells ; $B$, small stellate cell; $D$, large stellate cell. The branches marked $c$ are neurites.

FiG. 245.

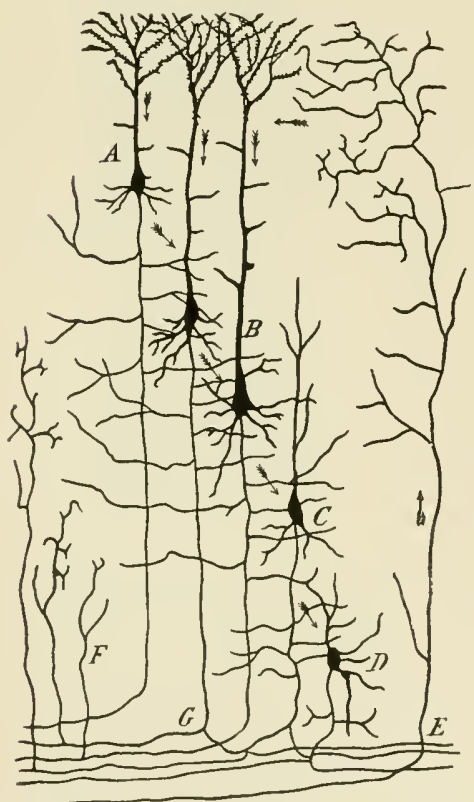

FIG. 246.

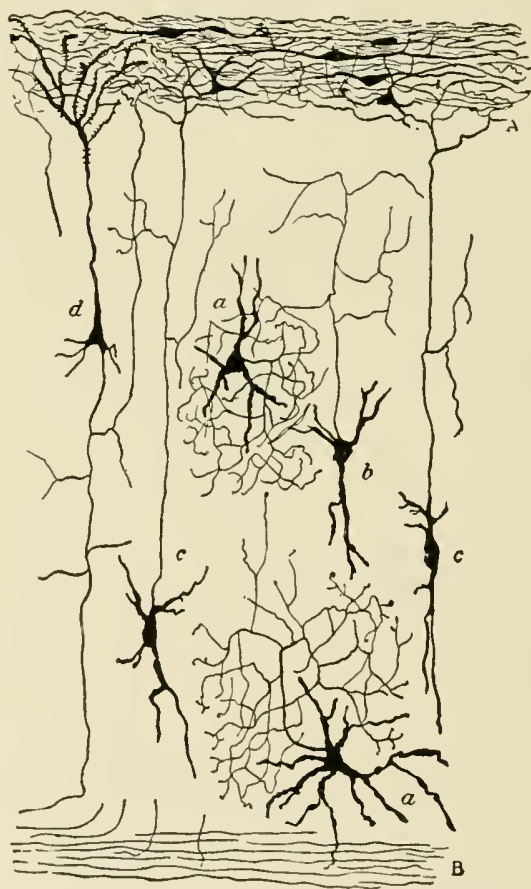

Fig. 245.-Diagrammatic section through the cerebral cortex. (R. y Cajal.) A, small pyramidul cell in the second layer; $B$, two large pyramidal cells in the third layer; $C, D$, polymorphic cells in the fourtl layer; $E$, centripetal neurite from distant nerve-centres; $F$, collaterals from the white substance; $G$, bifurcation of a neurite in the white substance. The arrows indicate the centripetal and centrifugal courses of nerve-impulses, but it is probable that centripetal impulses have to pass through other neurons (perhaps the spindle-cells of the molecular layer) before they are translated into centrifugal impulses.

Fig. 216.-Cells with short neurites in the cerebral cortex. (R. y Cajal.) A, molecular layer; B, white substance; $a$, cells with neurites, which speedily divide into numerous teleneurites in the neighborhood of the cell belonging to the same neuron; $b$, cell with a neurite extending vertically towarl, but not entering, the molecular layer: $c$, cell with a neurite distributed within the molecular layer; $d$, small pyramidal cell. 
the gray matter, and after their entrance into the white matter, these nemites give off" collaterals, which branch and end in terminal bulbous expan-ions without breaking up into a set of teleneurites.

The irregular cells of the fourth layer (Fig. 245, C,IJ) do not send their dendrites into the molecnlar layer, but distribute them within the deeper layers of the gray matter. Their neurities, like those of the prramidal cells, enter the white matter, where they may or may not bifureate.

Besides the cells in the deeper layers of the gray matter litherto described, those layers contain cells with short nemrites, which are divisible into two classes: first, spindle-shaped or stellate cells, sending their neurites into the molecular layer (Fig. 246, c) or into the second layer of the gray matter (Fig. 246, b); second, polymorphic cells with radiating dendrites and copiously branching neurites, both of which are distributed within a short distance of the cell. These cells are believed to distribute nervous impulses to the netrons in their vicinity.

The gray matter of the cortex also receives centripetal neurites from the white matter, which give off numerous collaterals and terminate in the molecular layer.

The white matter of the cerebrum contains fibres that may be divided into four groups: first, centrifugal or "projection" fibres; second, "commissure-fibres," which bring the two sides of the brain into coördination (these lie in the corpus callosum and in the anterior commissure); third, "association-fibres," which coördinate the different regions of the cerebral eortex on the same side; fourth, centripetal fibres, reaching the cortex from the peripheral nervous system or cord.

The centrifugal or projection-fibres arise from all parts of the cortex, springing from the pyramidal and, perhaps, also from the irregular cells. Many of these fibres give off a collateral, which passes into the corpus callosum, to be distributed in the cortex of the opposite side, commissural collaterals, and then pass on to the corpus striatum, to the gray matter of which further collaterals may be given off, after which the main neurite probahly passes into the pyramidal tracts of the cord through the cercbral crus (Fig. $247, a)$.

The commissure-fibres (Fig. 247, $b, c$ ) also arise from the pyramidal cells of the cortex, mostly from the smaller variety, and pass into the corpus callosum or the anterior commissure, to be dis- 
tributed in the gray matter of the cortex of the opposite hemisphere, but not necessarily to the corresponding region. These commissural

FIG. 247 .

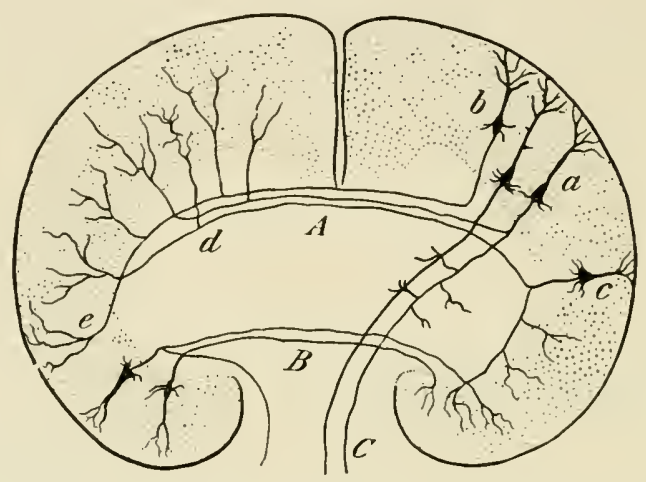

Centrifugal and commissural fibres of the cercbrum. (R. y Cajal.) $A$, corpus callosum: $B$, anterior commissure; $C$, pyramidal tract ; $a$, large pyramidal cell, with a neurite sending a large eollateral into the corpus callosum and then entering the pyramidal tract. Between $a$ and $b$ is a second similar cell, the neurite from which contributes no branch to the corpus callosum. $b$, small pyramidal cell giving rise to a commissural neurite; $c$, a similar cell, the neurite of which divides into a commissural and an association branch; $d$, collateral entering the gray matter of the opposite hemisphere; $e$, terminal teleneurites of a commissural fibre.

fibres give off collaterals, which also end in the gray matter, and are accompanied by collaterals from the centrifugal fibres, which likewise end in, and send collaterals to, the gray matter.

FIf. 248.

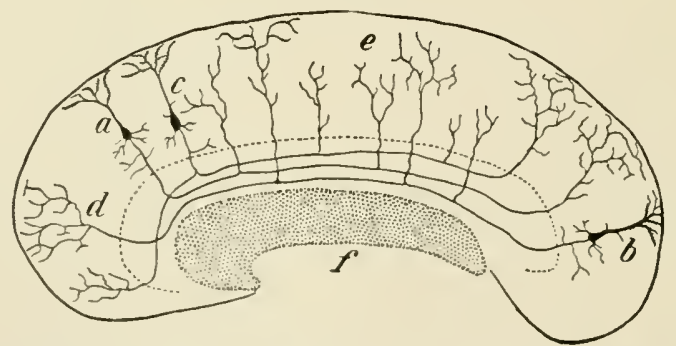

Association-fibres of the cerebrum. (R. y Cajal.) The figure represents, diagrammatically, a sagital section through one of the cerebral hemispheres. $a$, pyramidal cell, with neurite giving off collatcrals to, and ending iu, the gray matter of the same side; $b$, a similar cell; $c$, cell with a branching neurite lassing to different parts of the hemisphere; $d$, teleneurites; $c$, terminal collateral twigs.

The origin, course, and general distribution of the associationfibres are indieated in Fig. 248. They are so numerous that they 
form the great bulk of the white snbstance, where they are inextrieably interwoven with the other fibres there present.

Besides the centripetal neurites of the association and commissural neurons, their collaterals and those of the projection-fibres, the gray matter of the cortex receives terminal neurites fiom larger fibres that are probably derived from the cerebellum and cord (Fig. 245, $E)$. These give off numerons collaterals and teleneurites, which are distributed to the small pyramidal cells of the second layer, and probably also penetrate into the moleenlar layer, where they end in numerous teleneurites among the cells of that layer.

In the diagrammatic figure 245 the probalile course of nervous stimuli to and from the cerebral eortex is indicated. The possibilities of transmission within a strnetme of snch marvellous complexity are inealeulable.

The above struetural details of the central nervons system are chiefly taken from the publieations of Ramon y Cajal. They are the result of researches carried on by the application of the methods devised by Golgi to the nervous struetures of the lower vertebrates and embryos. Such details eannot be observed when speeimens have been hardened and stained by methods used for the study of other structures. In such specinens the nuelei of the nerve-eells and those of the neuroglia are stained and beeome prominent. But the multitude of nervous filaments lying between the cells and the processes of the neuroglia-cells are not differentiated, but appear as an indefinite, fincly gramnlar material, in which the cell-bodies apparently lie. Where the cells are sparse or small, as in the first layer of the cerebral gray matter, the tissme appears finely molecular. Where the cells are numerous but small, their stained nuelei give the tissue a granular appearance, as, for example, in the second layer of the cerebcllar eortex.

The brain and spinal cord are invested by a membrane of areolar tisine, ealled the "pia mater." Extensions of this areolar tissue penetrate the substance of the cord and brain, giving support to bloodvessels and their aceompanying lymphatics. This areolar tissue also extends into the ventrieles of the brain, where it receives an external covering of epithelium continuous with that lining the ventrieles, which is ciliated. Externally, the areolar tissue is condensed to form a thin superficial layer. 


\section{CHAPTER XIX.}

\section{THE ORGANS OF THE SPECIAL SENSES.}

1. Touch.-The nervous filaments distributed among the cells of stratified epithelium have already been depieted in Fig. 99. Similar filaments oecur in the human epidermis, and it is probable that some of them are the teledendrites of spinal ganglion-cells, while others are centrifugal teleneurites subserving the functions

FIG. 249

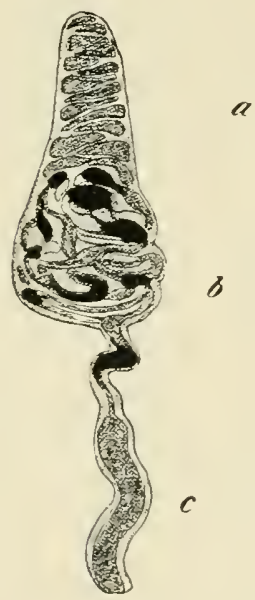

FIG. 250 .

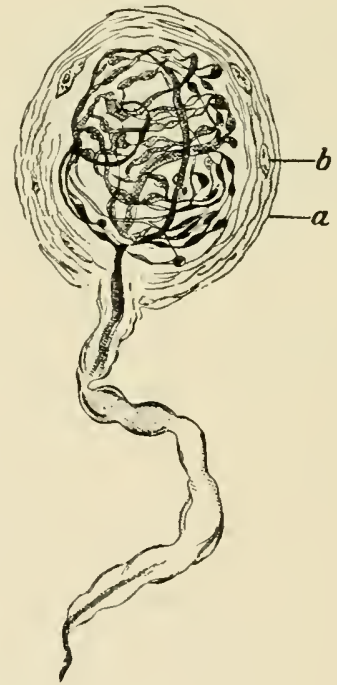

Tactile corpuscles

Fig. 249.-Meissner's corpusele, from the human corium. (Böhm and Davidoff.) a, upper portion, in which the epithelial cells alone are represented. The nuclei of those cells are in the broader peripheral portion of the cytoplasm; $b$, nerve-dendrite coiled about the epithelial cells; $c$, nerve-fibre.

Fig. 250.-Krause's corpusele, from the human conjunctiva. (Dogiel.) $a$, endothelial envelope; $b$, nucleus of connective-tissue cell within the fibrous capsule; $c$, nerve-fibre.

of nutrition, ete., or the teledendrons of neurons belonging to other than the spinal systen of nerves.

Besides these nervous terminations the skin possesses certain bodies, which are called "tactile corpuseles" and "Pacinian bodies." 
These are situated in the corium, the former lying in some of the papillax projecting into the rete mucosmm.

The tactile corpuseles are of two forms, differing slightly from each other in structure : first, those of Meissner, and, second, those of Krallse.

The tactile eorpuscles of Meissner (Fig. 249) eonsist of a group' of epithelial cells closely associated with the teledendrites of a nerve-fibre. The cells are closely compacted together to form an ellipsoid body. The nervous dendrite, with its medullary sheath, enters this body at one of its ends, and, after making one or two spiral turns around the mass of epithelial cells, loses its medullary sheath and breaks up into a number of teledendrons, which are distributed among the epithelial cells. The neurilemma and the endoneurium of the fibre are continued over the eorpusele, constituting a species of capsule.

The tactile corpuseles of Krause (Fig. 250) possess a capsule composed of delicate fibrous tissue, covered and lined with endothelial cells. The dendrite of the nerve-fibre loses its medullary sheath upon penetrating this eapsule, and then breaks up into teledendrites, that form a complex tangle within the cavity of the corpuscle. There appear to be no cells among the teledendrites, the interstices being occupied by lymph. These corpuscles are especially abundant in the conjunctiva and the edges of the eyelids, but oceur also in the lip, large intestine, posterior surface of the epiglottis, and the glans penis and clitoris. They may reeeive dendrites from more than one nerve. Those of Meissner are found throughont the skin, being most abundant where the tactile sense is most acute.

The Pacinian corpuseles (Fig. 251) are large oval bodies, composed of a number of concentric cellular lamellæ, surroming a central, almost cylindrical cavity, and covered externally with a layer of endothelioid cells, which appear to be continuons with the delicate endoneurium of the fibre. The latter enters the corpuscle at one of its ends, soon loses its medullary sheath, and is finally subdivided into a number of teledendrites within the eentral cavity.

"The "genital corpuseles" which are found in the glans of the penis and that of the elitoris are similar in structure to the Pacinian corpuseles, but the lamellar envelope of the latter is here reduced to one or two ill-developed lamellæ.

The nervous impulses inaugurated in the tactile and Pacinian 
corpuscles are probably tranimitted to the sensorium in the manner indicated in Fig. 240.

Pacinian eorpuseles are found in the palms and soles, on the nerves of the joints and periosteum, in the pericardium, and in the pancreas.

2. Taste.-The special organs of taste appear to be the taste-

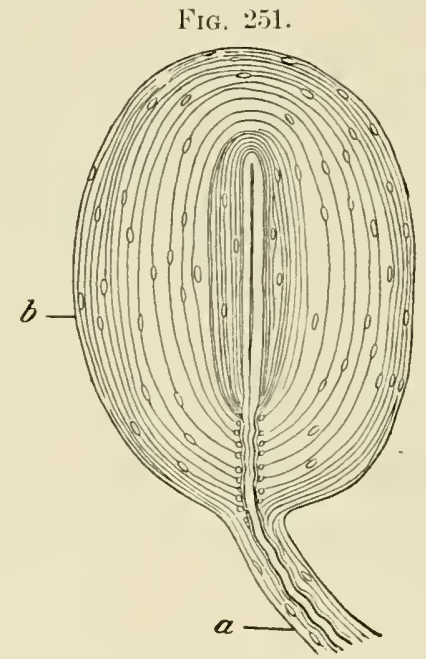

Pacinian corpuscle, from the mesentery of the cat. (Klein.) $a$, nerve-fibre; $b$, concentric capsule. The nature of the cells in this capsule is a matter of doubt; analogy would suggest their epithelial nature.

buds, sitnated in the walls of the sulei surrounding the cireumvallate papille of the tongue (see Fig. 116).

The taste-buds are bulb-shaped groups of epithelial and nervous cells, situated within the stratified epithelium lining the sulci. The cells composing these buds are spindle-shaped or tapering, and their ends are grouped together at the base of the bud and converge at its apex, where they occupy a "pore" in the stratified epithelium. The epithelial cells do not appear to be active in the inauguration of nerrous impulses, but the more spindle-shaped cells lying among them seem to be endowed with nervous functions. They may, possibly, be regarded as peculiar neurons; their distal processes, which receive stimuli at the pore, being the dendrite, while the proximal process is the nemrite. The latter divides into a number of minute branches, which, from this point of riew, might be regarded as telenenrites. Be this as it may, these branches come into close relations 
with the teledendrites of nerve-fibres supplied to the taste-bud (Fig. 252). The stratified epithelium surrounding the taste-buds, as elsewhere, contains teledendrites from sensory nerves.

3. Smell.-The olfactory organ oeeupies a small area at the top of the nasal vanlt, and extends for a short distance upon the septum and external wall. Its exposed surface is about equal to that

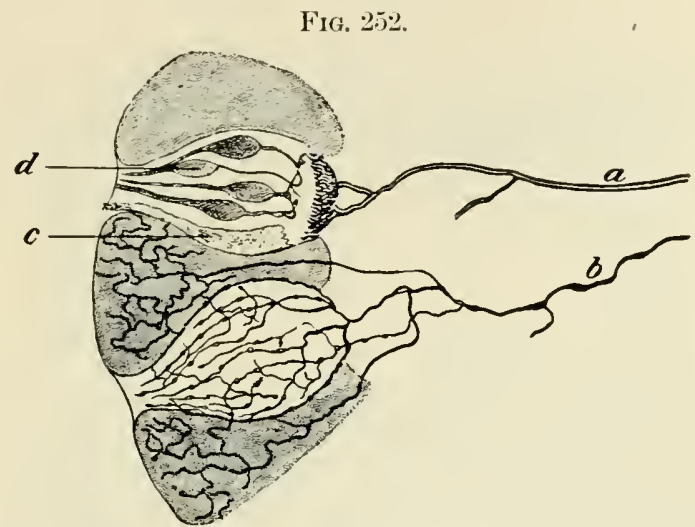

Diagram of a taste-bud and its nervous supply. (Dogiel.) a, radicle of the gustatory nerve : $b$, radicle of a sensory nerve; $c$, epithelial cell; $d$, nerve-cell. The shaded part of the figure represents the stratified epithelium lining the sulcus of the circumvallate papilla. Only one of the epithelial or supporting cells of the upper bud is represented in the figure; the others are omitted. The structure of the lower bud is not shown.

of a five-cent piece. It is a modified portion of the mueous membrane of the nose, which may be divided into this, the olfactory portion, and the general or respiratory portion.

The respiratory portion of the nasal mueous membrane is covered with a stratified, columnar, ciliated epithelium, with oecasional mucigenous goblet-eells, resting upon a basement-membrane. Beneath this is the membrana propria, resembling that of the small intestine in being rich in lymphadenoid tissue, which may, here and there, be eondensed into solitary follicles. Beneath the membrana propria is a richly vascularized submueous areolar tissue, containing compound tubular glands, the glands of Bowman, which open upon the surface of the mucous membrane. These glands seerete both mucus and a serous fluid.

In the olfactory region the columnar epithelial cells are devoid of cilia, but possess a thin cuticle, and the epithelium rests direetly upon the lymphadenoid tissue, without the intermediation of a basement-membrane (Fig. 253). Between these epithelial cells are the 
nervous cells, which contitute the receptive elements of the olfactory nervons tract. These are cells with large nuclei and eylindrical distal bodies, which terminate at the surface of the epithelial layer in several delicate hairs projecting from the surface (Figs. 254 and 255). The proximal ends of the cells rapidly taper to a delicate

FIG. 253.

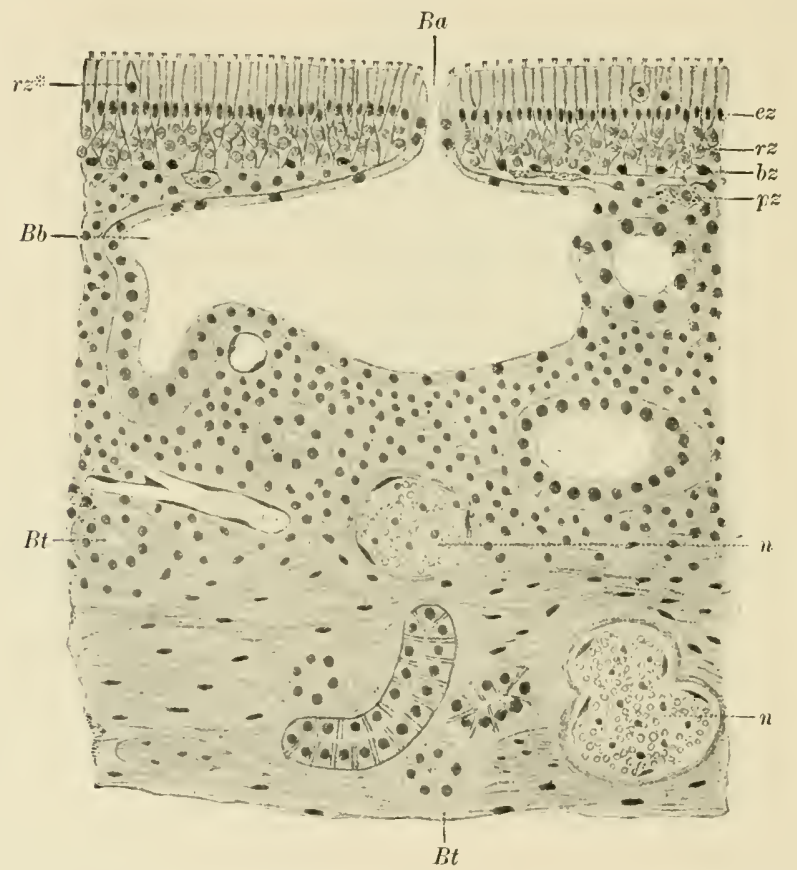

Vertieal seetion through the olfactory mucous membrane of the human nose. (Brunin.) $\epsilon z$, nuclei of the columnar cpithelial cells; $r z$, nuclei of the nervous or olfactory cells lying among those of the ejithelium : $b z$, nuclei of basal pyramidal epithelial cells lying among the branching proximal ends of the eolumnar epithelial cells and tapering ends of the nervous eells: $p z$, pigmented cell in the layer of lymphadenoid tissues beneath the epithelium; $B a$, duet of a gland of Bowman; $B b$, dilated subepithelial portion of the duct, reeeiving several of the tubular acini, $B t$. The connection between the duct and tubes is not shown. $n, n$, branehes of the olfaetory nerve; $r z^{*}$, atypical nervous eell.

filament, which extends throngh the subepitheliai tiswe and becomes assoeiated with others to form the olfactory nerve. The distal ends of the nerve-cells represent the dendrites of neurons, the nenrites of which form the axis-cylinders in the olfactory nerve.

The nemites in the olfactory nerve pass through the eribriform plate of the ethmoid bone to the olfactory bulb of the brain, where 
FIG. 254.

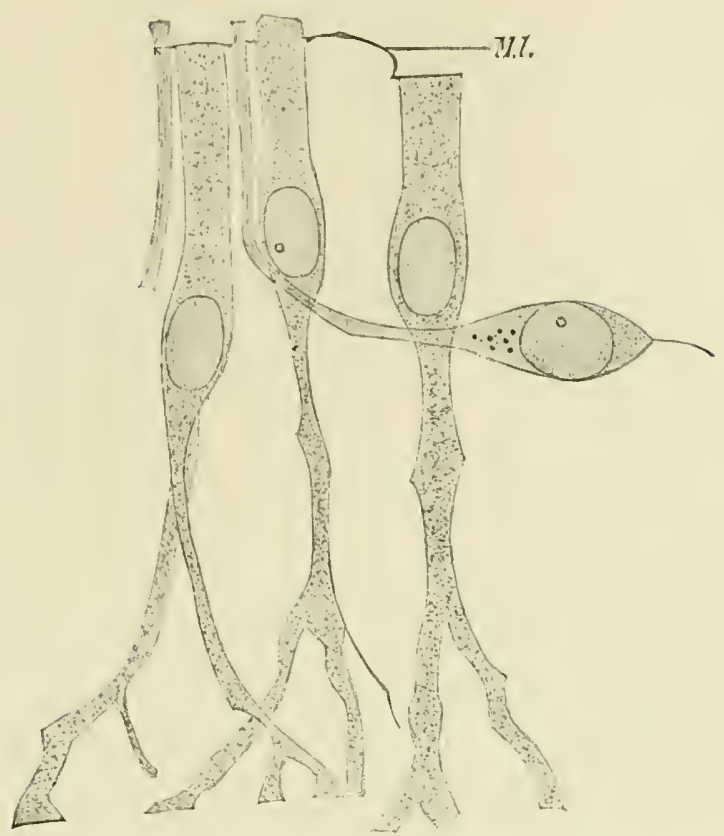

Epithelial layer of the human olfactory mucous membrane. (Brunn.) Isolated elements. Three epithelial cells, with forked proximal ends, are represented, together with a ner. vous cell bent out of position and the distal end of a second nervous cell. M.l, cuticle of the columnar eyithelium, which is not continued over the end of the nervous cell. The cuticle of neighboring cells unites at the edges to form a species of membrane, which appears to be perforated for the exit of the distal ends of the nervous cells. A similar cuticle is found in the retina, where it has received the name "limiting membrane."

FIG. 255.

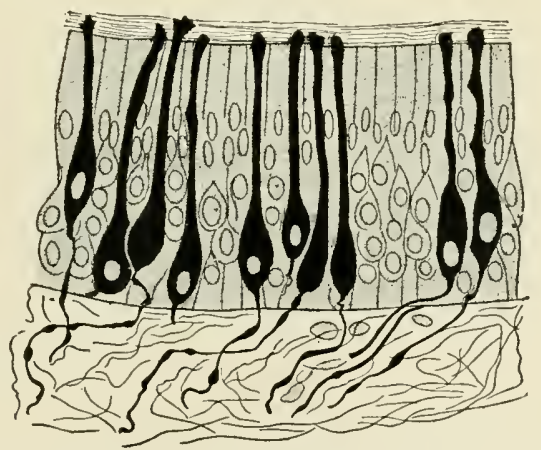

Vertical section of the epithelium, showirg the arrangements of its elements. The nervous cells, with their neurites, are black.

they terminate in teleneurites within little globular structures, called the "glomeruli of the bulb." 
The oltictory bulb maty be divided into five layers: first, the layer of peripheral nerves, containing the neurites of the olfactory nerve; secont, the layer containing the olfactory glomeruli; third, the molecular layer; fourth, the layer of the mitral cells; fifth, the gramular layer.

The first layer is, as alreatly stated, ocenpied by the neurites from the nerrous cells in the olfactory mucous membrane. These neurites constitute the axis-cylinders of the olfactory nerve.

The glomeruli of the secont layer are small globular masses formed by the closely associated teleneurites of the olfactory nerves and teledendrites from the mitral cells of the fourth layer, the dendrites from which pass through the third or molecular layer. A few cells of neurogliar nature may be associated with these nervous terminations, but the chief mass of each glomerulus is composed of interwoven teleneurites and teledendrites.

The third, or molecular, layer contains small spindle-shaped nerve-cells, which send dendrites to the glomeruli of the second layer and neurites into the granular (fifth) layer, where they turn and take a centripetal direction toward the cerebrum.

The fourth layer is characterized by the presence of large triangular nerve-cells, the mitral cells, the dendrites from which pass through the molecular layer, to end in teledendrites within the glomeruli. A single mitral cell sends dendrites to more than one glemerulus. The neurites from these cells pass, centripetally, to the olfictory centre of the cerebrum.

The fifth, granular, layer contains the centripetal neurites of the mitral cells, and also centrifugal neurites from the cerebrum. The latter are distributed in teleneurites within the granular layer itself. This layer also contiins small polygonal nerve-cells of two sorts: first, cells resembling those of the third type represented in Fig. 232, the processes from which are distributed in the granular and molecular layers. They are probably association-cells. Second, cells (Fig. 256) with dendrites in the granular layer and teleneurites in the molecular layer. These cells would distribute impulses received from the centrifugal fibres, which end in the granular layer, among the teletentrites in the moleenlar layer.

The sense of smell, then, is aronsed by stimulations of the distal ends of the nervous cells in the olfactory mueous membrane (Fig. 256), which are transmitted to the glomeruli, where they leave the first neuron, being communicated to the secont, represented by the 
mitral cells and their processes, by which they are conveyed to the cerebral cortex. In its passage through this tract numerous collat-

FIG. 256 .

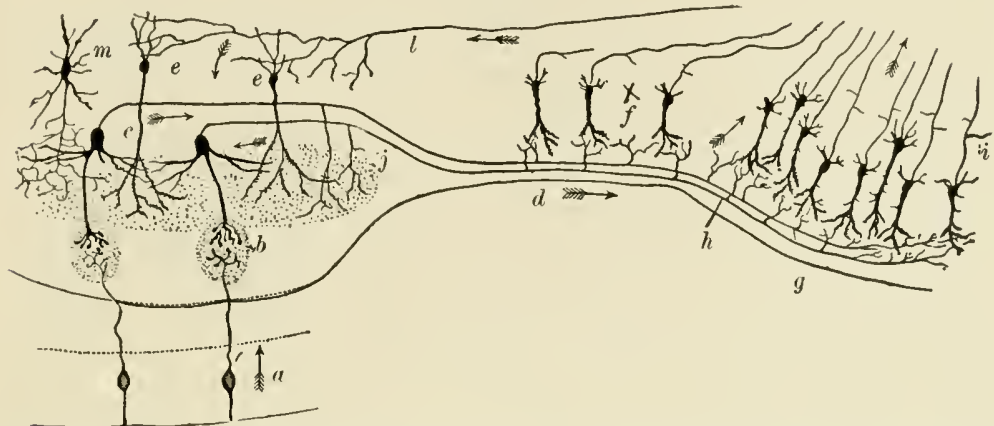

Diagram of the nervous mechanism of the olfactory apparatus. (R. y Cajal.) $a$, olfactory portion of the nasal mucous membrane; $b$, second or glomerular layer of the olfactory bulb $j$, at the right edge of the molecular layer, which is dotted. The cells of this layer are omitted. $c$, fourth layer of the bulb, the layer of the mitral cells, two of which are represented $; e, m$, cells of the fifth or granular layer; $d$, olfactory tract; $g$, cerebral cortex; $h$, neurite from a mitral cell, giving off a collateral to the dendrites of a pyramidal cell in the gray matter of the brain ; $f$, pyramidal cells of the olfactory tract; $j$, collateral from a mitral neurite passing, recurrently, into the molecular layer; $l$, centrifugal neurite from the cerebrum.

eral and association-tracts may be influenced in a manner too complicated to be readily followed.

FIG. 257.

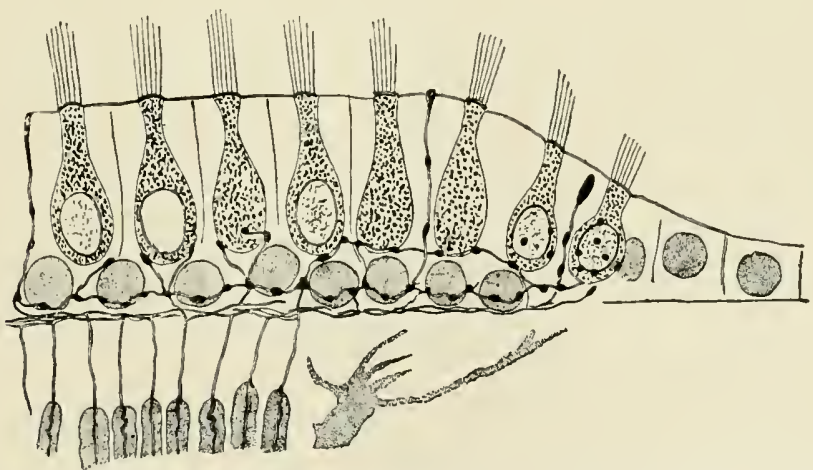

Diagram of the distribution of the anditory nerve within the mucous membrane of the crista acustica. (Niemack.) The bodies of the hair-cells are dotted. Between them are the cells of Deiters, the nuclei of which are shown below the hair-cells. The nervous filaments are distributed between these cells.

4. Hearing.-The acoustic nervous apparatus resembles somewhat that which subserves the sense of touch. The receptive portion consists 
of a laycr of epithelium containing two sorts of cells : first, ciliated cells, which are somewhat flask-shaped and are called "hair-cells"; second, epithelial cells, the "cells of Deiters", which surromel and enclose the hair-cells, except at their free ends, and reach the surface of the mueous membrane, where their ends are cuticularized. These cells of Deiters extend from the surface of the membrane to the basement-membrane, while the hair-cells extend only for a portion of that distance.

The dendrites of the auditory nerve are distributed among these cells, but are not in organie union with them (Fig. 257). In this respect the anditory apparatus differs from the olfactory and resembles the tactile. The nerrous dendrites are processes of bipolar ganglion-cells situated in the ganglia on the branches of the anditory nerve. The neurites from those cells presumably carry the nervous stimuli to the cerebrum. The bipolar cells are, therefore, analogons to the posterior root ganglion-cells of the spinal nerves. Whether this single neuron carries the nervons stimulus direetly to the cerebral eortex cannot be stated, but it is probable that there is an intermediate neuron in the tract of transmission, perhaps in the medulla oblongata.

The external anditory meatus is lined with skin containing compar:1tively few papillæ. The ceruminous glands which secrete the wax resemble the sweat-glands of the skin. The deep portions of these coiled tubular glands have a rather wider lumen than the sweat-glands and are lined with a single layer of cubical epithelium containing granules of pigmented material and fit destined to become constitnents of the cerumen. The ducts of the glands are lined with a double laver of epithelial cells. Mnscular fibres are present in the walls of the glands, the arrangement being similar to that in the sweatglands. The skin extends over the, outer surface of the tympanic membrane, but here the corium is very thin and devoid of papillie. The rete Malpighii is also thin. Beneath this skin, but separated by a thin vascularized layer of areolar tissue, is the tympanic membrane, consisting of two layers of fibrous tissue, an outer in which the fibres run radially, and an inner composed of cirenlar fibres. The inner covering of the tympanic mombrane is a single layer of flattened epithelinm resting on a small amount of vascularized areolar tissue. The tympanic cavity (middle ear) is also lined with flattened epithelium in a single layer which passes into ciliated epithelium near the opening into the Eustachian tube, likewise lined 
with ciliated epithelinm continuous with that of the nasal eavity into which its other extremity opens.

5. Sight.-The reeptive nervons organ of vision is the retina. This has an extremely complicated strueture, which may be divided into the following nine layers:

1. The layer of pigmented epithelium, which lies next to the choroid coat of the eye, and is, therefore, the most deeply situated coat of the retina; 2 , the layer of rods and eones; 3 , the external limiting membrane; 4 , the outer granular layer; 5 , the onter molecnlar layer; 6 , the inner granular layer; 7 , the inner molecular layer ; 8 , the ganglionie layer; 9 , the layer of nerve-fibres.

Internal to the ninth layer is the internal limiting membrane, which separates the retinal structures from the vitreous humor oceupying the eavity of the eyeball. The general charaeter and associations of these layers are shown in Fig. 258.

1. The layer of pigmented epithelium is made up of hexagonal cells, which are separated from each other by a homogeneous cement and form a single continnons layer upon the external surface of the retina. They are in contact with the rods and cones of the next layer, and send filamentous prolongations between those structures. The pigment lies within these filamentous processes and the portion of eytoplasm continuous with them, but its position varies with the functional aetivities of the organ. When the eye has been exposed to light the pigment is found lying deeply between the rods. When the eye has been at rest for some time the pigment is retracted in greater or less degree within the body of the cell.

2. The rods and cones are the terminal struetures of cells which extend from the fifth layer to the first. 'The melei of these cells lie within the fourth layer, to which they give a granular appearance (Fig. 258).

3. The external limiting membrane is formed by the cuticularized outer ends of certain sustentacular epithelial cells, the "cells of Müller" (Fig. 258, x), which extend from this layer to the internal limiting membrane and serve to support the various elements of the retina. The nuclei of these cells lie in the seventh layer, to the granular eharacter of which they contribute. The portion of the cell which lies in the fourth layer of the retina is indented with numerous oval depressions receiving the nuclei of the cells carrying the rods and cones, which they both support and isolate from each other. The filamentous cell-bodies of those elements 
are also separated by the cells of Miiller. In the sixth and seventh layers delicate processes from these cells serve a similar purpose, and in the eighth layer their deep extremities fork to give support to the ganglion-cells. Beyond the ninth layer the ends of these forks expand and come in contact with each other at their edges to form the "internal limiting membrane."

F1G. 253.

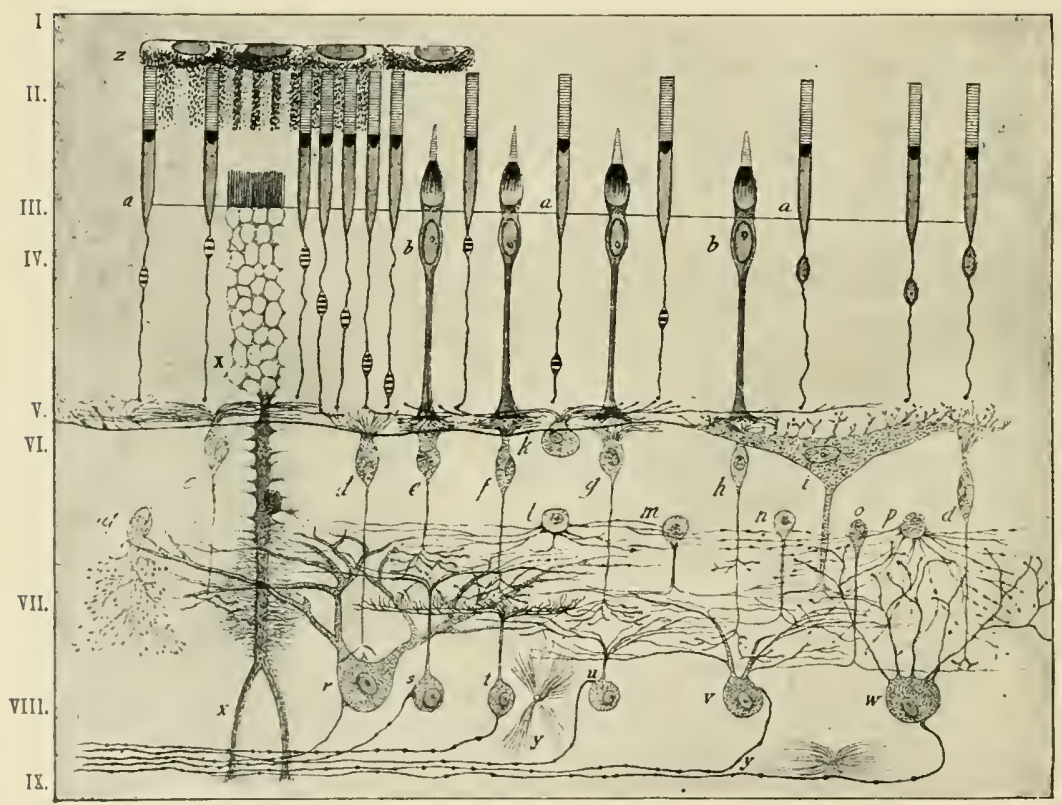

Diagram of the retina. (Kallius.) I., pigmented epithelial layer: II., layer of the rods and cones; III., external limiting membrane; IV., outer granular layer; V., outer molecular layer; VI., inner granular layer; VII., inner moleeular layer; VIll, ganglionic layer; IX., layer of nerve-fibres. $z$, pigmented epithelial eells; $a$, at the bottom of the external limiting membrane, rods; $b$, cone cells; $c-h$, ganglion-cells of the sixth layer conneeting the fourth layer with the eighth; $i$, horizontal cell sending a process into the seventh layer; $k-q$, "spongioblasts," or neurons of the third type (Fig. 252); $r-w$, ganglion-cells of the eighth layer; $x$, sustentacular cell of Müller, with striated upper end forming a part of the external limiting membrane; $y, y$, neuroglia-eells. It should be borne in mind that in sections of the retina numerous elements of the various sorts here represented are erowded together to form a compaet tissue. The centrifugal fibres which reach the retina from the cerehrum are omitted from this diagram. They are distributed in the inner granular or sixth layer. The light entering the eye passes through the layers represented in the lower part of this figure before it ean affict the rods and cones.

4. The fourth, or outer granular layer contains, as already stated, the nuclei and elongated bodies of the cells that carry the rods and cones of the second layer. The bodies of the former are almost filamentous in character, but expand to enclose the oval nucleus, 
which lies at various depths in different cells. The eell-body expands again near the external limiting membrane, through which it passes to form the rod. At the other end the filamentous eellbody terminates in a minute knob in the fifth layer of the retina. The cells which form the cones have nuelei lying near the external limiting membrane and cylindrical bodies terminating in a brush of filaments in the fifth layer.

5. The outer moleenlar layer, also called the "outer plexiform layer," owes its appearanec to a multitude of filaments, part of which have been deseribed as the terminations of the cells bearing the rorks and cones, the rest being the terminations of nerve-processes springing from the cells of the sixth layer.

6 . The sixth layer has a granular appearance, beeause of the presence within it of the cells of a great number of short neurons. These are of two sorts : first, those belonging to the first type, represented in Fig. 232, which have dendrites in relation in the fifth layer with the filaments of the cells bearing the rods and eones, and neurites that come into relation in the seventh layer with the dendrites of ganglion-cells lying in the eighth layer; seeond, neurons of the third type, shown in Fig. 232, which, in this sitnation have been called "spongioblasts." These, whieh we may regard as association-neurons, form two groups : first, those which send

FIG. 259.

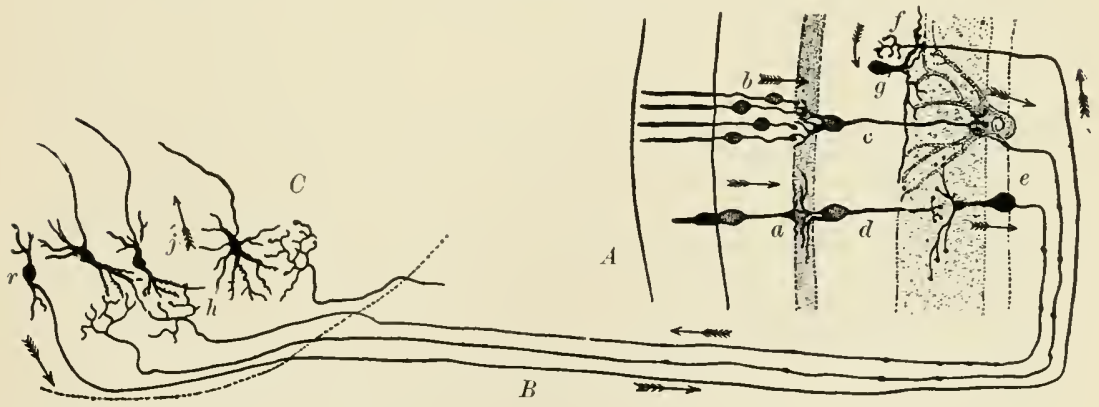

Diagram of the nervous mechanism of vision. (R. y Cajal.) $A$, retina; $B$, optic nerve; $C$, corpus geniculatum. $a$, eone; $b$, rod; $c, d$, bipolar nerve-cells of the outer granular layer; $e$, ganglion-cell ; $f$, centrifugal teleneurites ; $g$, "spongioblast"; $h$, teleneurites from optic nerve; $j$, neuron reeeiving and further transmitting the nervous impulse; $r$, cell transmitting the eentrifugal impression. The courses of nervous impressions are indicated by the arrows.

processes into the fifth layer; and, second, these which send their processes into the seventh layer; but, aside from the neurons in- 
eluded in these two groups, there are certain cells (Fig. 258, i) which send processes into both the fifth and the seventh layers.

7. The seventh, inner molecular or "inner plexiform" layer owes its delicate structure to the fact that it is here that the teleneurites of the cells in the sixth layer come into relations with the teledendrites of the ganglion-cells of the eighth layer.

8. The eighth layer contains those ganglion-cells whose teledendrites receive impressions from the teleneurites derived from the sixth layer, and send their neurites into the optic nerve. These neurites form the chicf constituent of the ninth layer of the retina.

It will be observed in Fig. 258 that the basal expansions of the cells bearing the cones are mostly in relation with the teledendrites of a single neuron of the sixth layer, and that this neuron is, again, in close relations with the teledendrites of but one ganglion-cell of the eighth layer. This arrangement would not favor a diffusion of the impressions inaugurated in the cones. The arrangement is quite different in the case of the cells bearing the rods.

The probable course of nervous impressions to and from the retinal elements is represented in Fig. 259. 


\section{HISTOLOGICAL TECHNIQUE.}

\section{CHAPTER XX.}

PRACTICAL SUGGESTIONS FOR THE CARE AND USE OF THE MICROSCOPE.-MICROSCOPICAL TECHNIQUE.

Is selecting a microscope the following considerations are of importance :

The stand should be supported on three points and rest firmly on the table; have a rack-and-pinion coarse adjustment, and a fine adjustment free from all loss of motion. It is rarely used in an inclined position, and a jointed stand is unneeessary. A triple nose-piece, or revolver, is a great convenience, and an Abbe condenser with iris-diaphragm is almost indispensable.

Three objectives are needed: a Leitz No. 3 or No. 4, No. 7, and $\frac{1}{10}$ th or $\frac{1}{12}$ th oil immersion, or their equivalents of other manufacture, are suitable powers for general use. Two oculars, No. 2 and No. 4, will answer.

'The mieroseope should be protected from direct sunlight and aeid fumes, and be kept in a dry, moderately cool place. When not in use it should be eovered or placed in its case, to protect it from dust. If the lenses become dirty, they may be wiped with a soft, clean eloth or Japanese paper, either dry or moistened with water, and followed by a dry eloth or paper. Balsam or cedar oil may be removed with a eloth or soft paper moistened with xylol, after which the parts should be carefully wiped dry.

In making microchemical tests special care should be taken not to let the reagents come in eontact with the objectives.

Objeets should always be examined in a liquid, unless there is some special reason for examining them in a dry state; and should be covered with a covel-glass, umless a cursory inspection with a very low power is all that is required. 
In studying a specimen always use the lowest power that will reveal the structures it is desired to see; and, in any event, use a low power first, to gret a general idea of the topography of the specimen. In this way the portions for more minute study can be readily selected, with a great saving of time.

The proper illumination of the specimen is just as important as careful focussing. If the Abbe condenser is in use, employ the plane surface of the mirror during the day; either the plane or the concave surface when artificial light is used, selecting the surface which eauses less glare. The iris-diaphragm should be kept adjusted so as to give the best definition of the specimen under examination when the latter is in focus. It will be found that when colorless oljects are examined a small opening gives the clearest pieture, while with colored objects a larger opening is preferable. A small diaphragm serves to bring out the "structure-pieture"; a large diaphragm, the "color-picture" (see p. 281).

A bottle of oil of cedar-wood, having approximately the same refractive index as the glass from which the cover-glasses are made, is furnished with the immersion-objectives. When these are used a drop of this oil is placed on the eorer, and the end of the objective immersed in this drop. This arrangement permits the light to pass from the object to the bottom lens of the objective without sensible refraction, increasing the amount of light entering the objective, the sharpness of definition, and the purity of the color-picture. When the lens has been used the oil should be removed with a soft cloth or Japanese paper. The oil on the eover may be wiped off at once, or it may be allowed to dry and then removed with a eloth moistened with xylol.

Microscopical Measurements.-These may be made, with a fair degree of aceuracy, by means of an eye-piece micrometer-scale. This is a ruled dise of glass that ean be placed upon the diaphragm within the ocular, where its seale should be well defined when seen through the upper lens of the eye-pice. Special micrometer oculars are made which permit of focmssing the seale, but these are unnecessary if the diaphragms of the ordinary oculars are in the right places within the eve-piece tubes. The value of the divisions of the eye-piece micrometer-scale nust be determined by comparing it with the scale of a micrometer-slide which is placed upon the stage of the microscope. These scales usually consist of $1 \mathrm{~mm}$. divided into hundredths, and the eye-piece seale will have dif- 
ferent values for each combination of lenses used and for every variation in the length of the mieroseope-tube. The unit for mieroscopical measurements is one-thomisudth of a millimeter, or onemillionth of a meter; it is called a "micrometer," and is designated by the (areek letter $\mu$. One division of the micrometer-slide mentioned above would, therefore, equal $10 \mu$. From these data it is possible to calculate the value of each division of the eye-piece micrometer-seale in terms of $\mu$ for each combination of lenses, the length of the microscope-tube being fixed. (Most Continental stands and many Ameriean stands have graduated tubes, and the objectives are constructed for a standard tube-length of 160 millimeters.)

It is well for the student to get into the habit of estimating the sizes of the objects he examines. A good standard for mental comparison is the diameter of the unaltered red blood-corpuscle, which is about $7.5 \mu$.

\section{MICROSCOPICAL TECHNIQUE.}

Useful preparations for stndy under the microscope may be prepared from tissues in one of three ways: 1 , simple serapings of the tissues may be mounted on a slide in the fluids derived from the tissues themselves, or in a nentral solution-e.g., 0.75 per cent. salt solution ; 2, the tissme-elements, cells, and intercellular fibres, ete. may be separated from each other by treatment with some macerating-fluid-e. g., very weak chromic acid $(1: 10,000), 36$ per cent. caustic potash, $\frac{1}{3}$ alcohol ; 3 , sections of the tissue may be prepared either while they are fresh, with a razor or a freezing-microtome, or after hardening.

The first method has a limited application. It is serviceable only when the tissue-elements are so loosely held together that they readily separate from each other and can be examined in an isolated condition. This is the ease with a considerable number of tumors, the superficial tissues of mucous membranes, the spleen, ete. If the inside of the cheek be scraped with the finger-nail, and the material thus removed be diluted with saliva, placed upon a slide, and covered with a cover-glass, the sinamous epithelial cells lining the cavity of the month will be readily seen in an isolated state. An appropriate dye may now be introduced under the cover, and by its meins the melei of the cells stained, thus bringing them into clearer view. 
When a simple scraping of the natural or freshly cut surface does not yield useful preparations, showing isolated tissue-elements, some process of maceration may be employed. Bits of the tissue are soaked for a time in some solution that serves to soften the cementsubstances lying between the elements of the tissues, so that they may be casily separated with needles (teasing). Such specimens are usually best examined when mounted on a slide in some of the macerating-fluid. Many of the macerating-solutions not only favor the separation of the constituents of tissues, but also preserve them, so that a fair idea of their natural size and shape may be obtained from such preparations. It is evident, however, that with this method very little can be learned of their arrangement in the tissues before they were separated, and a knowledge of that arrangement is often of greater importance in the determination of the character of the tissue than a knowledge of the exact shape and size of the tissue-elements.

The third method, that of preparing sections of the tissues, is the one most commonly employed, because it yields the most useful results. The structural elements composing the tissues are seen in their natural relative positions, and can be distinguished from each other and identified by the nse of dyes and other reagents that affect them in some characteristic manner. But in order to obtain useful sections the tissues must almost always undergo some preliminary treatment with reagents, to give them a proper consisteney for cutting and to hold the tissue-elements together so that the sections shall not fill apart after they have been cut. This may be accomplished by freezing the tissue before cutting it ; but more satisfactory results are obtained by cansing a coagulation of the albuminous substances and subsequently extracting some or all of the water contained in the tissucs. These changes in the tissues give them a firmness which favors the preparation of very thin sections; but sometimes even they are inadequate, and then the tissues are usually impregnated with some substance, like paraffin or collodion, which fills the interstices of the tissues and can then be hardened, when it serves to hold the tissue-elements together and retain them in their natural positions. The paraffin or hardened collodion is cut with the tissues and keeps the sections from disintegrating. Before mounting the section, the substance used for impregnation may he removed from the section, or it may be retained 
permanently, since it is u-nally asily recognized in the specimen and does not interfere with its study under the microscope.

The study of tissues hy means of seetions has the disudvantage that the elements of the tissues are eut, and the sections contain the resulting portions as well as complete elements. The incomplete portions lie near and at the surfaces of the sections, where they are in clearest view, while the uncut elements are situated in the body of the section, more or less obscured by the overlying portions that have been ent by the knife. Moreover, the tissue-elements may lie obliquely to the plane of the section, so that only a portion of them can be seen at a time, the rest being brought into clear view only when the focal plane is raised or lowered. 'These circumstances and the fact that the tissue-elements are frequently closely crowded together make the interpretation of sections a matter of some difficulty in many cases. These difficulties are in a measure overeome by examining sections of different thicknesses, but a more satisfactory way of studying the structure of a tissue is to examine portions after maceration as well as in section.

The processes of coagulation and dehydration, which have already been mentioned as usual preliminaries to the cutting of sections, deserve a few words in explanation of their purposes.

The coagulation of the albuminous substances in the tissues has for its chief aim the preservation of the minute structure of the tissue-elements, so that a lapse of time or the subscquent manipulations of the tissues shall not cause an alteration in the details which it is desired to study. If this precaution be omitted, the tissues undergo post-mortem changes which seriously alter the appearance of the elements of which they are composed. Coagulation bronght about for this purpose is ealled "fixation" of the tissues. It may be indueed in a variety of ways: the tissues may be subjected to heat for a few moments, thus rendering the albumins they contain both solid and insoluble; but the more usual procedure is to immerse the tissues in a solution of some substance that causes rapid death with coagulation. These solutions are called fixingsolutions, and not infrequently the substances they contain not only cause death and coagulation, but al,o form a union with some of the structural materials of the tissues which may faeilitate their subsequent recognition.

The number of formula that have been devised for the preparation of fixing-solutions is very great, and some of the solutions are 
better for the fixation of some tissues than for others. As a rule, those solutions that most perfectly preserve the finer intracellular details of structure have very little power of penetrating masses of tissue. They ean, therefore, only be employed when very small bits of tisule are to be fixed. Other fixing-solutions penetrate much better, but fail to fix the most delicate structures, which may undergo changes before they are preserver. It follows that the choice of the method of fixation must in each ease depend upon the object to be attained.

The removal of water from the fixed tissues is accomplished by means of alcohol. The fixing-agents are nearly all aqueous solutions, and while they increase the eonsistency of the tissues to a certain extent, they do not usually render them suffieiently firm for the preparation of thin and miform sections. If the water in the tissues be replaced by alcohol, a greater and more uniform eonsisteney is obtained, and the tissues are also partly prepared for inipregnation with an embedding-material (collodion or paraffin) should that be necessary for scetion-entting.

After sections of fixed tissues have been obtained they usually require staining before they can be profitably studied. The chief reason for this will appear in the following explanation:

When a specimen is examined under the microscope differences in structure among the colorless elements of the specimen may be seen, or differences in color between the different elements may be perecptible. We may, then, distinguish between a "structurepieture," due to rlifferences that are not those of color, and a "colorpieture," due solely to such differences. The manner in which the latter is produced is, perhaps, self-evident. The structure-pieture is the result mainly of differences in refraction due to the various densitics of different parts of the specimen. But the processes of fixation and hardening have for their purpose the rendering of the tis-sues of a relatively miform density. They must, in consequence, tend to obliterate the details of the structure-picture which the sections yichl when viewed under the microseope. For this reason the sections are stained, which converts the structure-picture into a color-pircture.

The sulstances composing the tissues have varions affinities for lyes, and it is possible to take advantage of this in staining sections, so that structures of the same nature shall receive one color, while those of different composition shall be dyed of a different 
hue or an entirely different color. The coloring-matters, when so employed, not only bring out the structure of the tissue by ereating at color-pieture, but they also serve as valuable reagents in revealing the nature of the substances to which they impart a color. Again, it is often necessary that a certain method of fixation or other preliminary treatment should be used before the partienlar dye seleeted can display its greatest selective power for a particular sulsstance. These facts explain the great number of formula for stains and the preparation of specimens that are found in the technical text-books and journals. The subject has become so expanded within recent years that it has almost created a distinet branch of learning; but it will only be necessary for the student of medicine to acquire a knowledge of a few methods that will serve to reveal the general structure of cells and the characters of the intercellular substances. The general outline of the procedures in common use for this purpose are as follows: 1 , fixation; 2 , hardening; 3 , impregnation; 4 , embeddling ; 5, eutting ; 6 , staining ; 7 , dehydration ; 8 , clearing ; 9 , mounting.

Some methods of preparation combine one or more of these steps in a single manipulation, thus considerably reducing the time requisite for the completion of the proeess. Other methods necessitate the intercalation of still other manipulations, or the subdivision of those already enmmerated.

\section{Methods of Fixation.}

1. Muller's Fluid.-This classic fixing-and hardening-solution consists of potassium bichromate, 2.5 per cent., and sodinm sulphate, 1 per cent., dissolved in water (preferably distilled water). It is slow in action, requiring from six to eight weeks for the preservation of an average specimen, but with proper eare can be made to yield excellent results when the finer details of stmeture are not to be studierl. It is important to use large quantities of the fluid, at least ten times the rolume of the tissues immersed in it, and to renew the fluid so frequently that its strength shall be constantly maintained. When fresh tissues are placed in Müller's fluid they speedily render it cloudy. This is a sign that the fluid should be renewed, even if only an hour has elapsed since the tissues were placed in it. When cloudiness no longer appears the fluid should be renewed once a day for the first two weeks: after that, two or three times a week till the process is completed. 
After fixation in Müller's fluid specimens shonld be washed in running water over night, or for twenty-four hours, and then hardencel in alcohols of progressively greater strengths. While in the weaker alcohols specimens should be kept in the dark, to avoid the formation of precipitates, which oceur under the influence of light. Picees of tissure placed in Mïller's fluid should not be more than 1 cm. in thickness.

Two excellent modifications of Müller's fluid have been devised by Zenker and Orth for the purpose of hastening the fixation and of securing a more faitlful preservation of structural detail.

\section{Zenker's Fluid.-}

Potassinm bichromate,

Sodium sulphate,

Mercuric ehloride,

Distilled water,
2.5 grams.

1 gram.

5 grams.

$100 \mathrm{ec}$.

To this stock solution 5 per cent. of glacial acetic acid is to be added just before use of the fluid.

Zenker's fluid fixes tissues in from three to twenty-four hours. The pieces should not be more than $5 \mathrm{~mm}$. thick, and after fixation shonld be washed for several hours in rumning vater and then hardened in alcohol.

This solution possesses the disadvantage that a preeipitation of mereury or some mereurial compound is likely to take place within the tissues. This deposit nay be, at least in great measure, removed from the tissnes by adding a little tincture of iorline to the hardening-aleohols. The indine combines with the mercury and produces a soluble compound, which is dissolver out by the alcohol. As the iodine disappears from the alcohol the latter becomes bleached, and fresh tincture must be added until the aleohol remains permanently tingerl. If, after sections of the tissue have been prepared, they are found to eontain a mereurial deposit, this can be removed by tratment with alilute iodine tincture or with Jugol's solution.

\section{Orth's Fluid.-}

$$
\begin{aligned}
& \text { Potassium bichromate, } \\
& \text { Sodium sulphate, } \\
& \text { Distilled water, }
\end{aligned}
$$

\section{5 grams.}

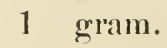

$100 \mathrm{ce}$.

'This stock solution is Miiller's fluid. Before use, 10 ec. of for- 
maldehyde (40 per cent.) is to be added to every $100 \mathrm{ce}$. of the Miiller's fluid.

Orth's fluid fixes in three or four days. The pieces of tissue should not be more than $1 \mathrm{~cm}$. thick. The time for fixation ean be shortened if smaller pices are used and the process is earried on at a slightly elevated temperature; $e . g$., in an incubator kept at $37^{\circ} \mathrm{C} .\left(98.6^{\circ} \mathrm{F}\right.$.). After fixation the specimens should be washed in running water, as in the previous methods.

4. Mercuric Chloride Solution.-A saturated solution of eorrosive sublimate in 0.5 per cent. salt solution is prepared by heating an exeess of sublimate crystals in the salt solution and allowing the mixture to cool. The clear fluid is decanted from the crystals when desired for use. The penetration and action of the solution are favored by the addition of 5 per cent. of glacial acetic acid at the time of using. The thickness of the pieces of tissue should not exeeed $5 \mathrm{~mm}$., and much thinner pieces are better. Fixation takes place within six hours, after which the tissues may be washed in running water, or placed at once in 70 per eent. alcohol. If acetic acid has been used, it is best to wash in water before immersing in alcohol. Tincture of iorline should be added to the alcohol for the reasons given in the description of Zenker's fluid.

5. Formaldehyde.-This gats is capable of being absorbed by water to form a 40 per cent. solution, but its volatility renders such a solution liable to deterioration. The strength employed for fixation is usually 4 per cent., and may be prepared by adding $10 \mathrm{ce}$. of 40 per cent. formaldehyde to 90 ce. of distilled water. A 0.75 per cent. solution of common salt may be substituted for the distilled water with possible advantage and the addition of about 2 per cent. of acetic acid is also advantageous.

Formaldehyde penetrates deeply and quickly into the tissues, which may be $1 \mathrm{~cm}$. in thickness, and accomplishes fixation within twenty-four hours, but the preservation of structural detail is not very perfect. The solution is useful where the general characters of the tissues are to be determined and the details of the cells are of comparatively little consequence. After fixation the tissues may be washed in water, or placed direetly in 70 per cent. alcohol; or frozen sections may be at once prepared. Satisfactory sections may be obtained from small pieces of tissue if they are put in the formaldehyde solution for an hour or two and then ent with the freczing-microtome. After they have been washed for a short time in water they may be stained by any of the more usual methods. 
6. Flemming's Solution.-This is a solution containing osmic acid, chromic acid, and acetic acid. It does not keep well, and it is best to prepare it just before it is to be used. For this purpose the following stock solutions may be kept on hand:

A. 2 per cent. solution of osmic acid in 1 per eent. chromie acid.

B. 1 per cent. solution of ehromic acid in distilled water.

Osmic acid may be bought in sealed tubes containing either $\frac{1}{2}$ or 1 gram. To prepare the stock solution "A," the tulse should be washed on the outside and a deep file-scratch made near its centre. It should then be broken into a bottle containing 50 ce. of a 1 per cent. solution of chromic aid in distilled water. The halves of the tube should be dropped into the bottle and its contents shaken at intervals until solution is effected. This solution had best be kept in the dark to avoid decomposition of the osmic acid. When required for use, prepare the Flemming's solution by mixing:

$\begin{array}{lr}\text { Solution "A," } & 4 \mathrm{cc} . \\ \text { Solution "B," } & 15 \text { " } \\ \text { Glacial acetic acid, } & 1 \text { " }\end{array}$

Flemming's solution is especially useful for fixing the finer details of structure within the cell. It was devised for the preservation of the mitotie figures formed during karyokinesis, but its range of usefulness far exeeds that limited applieation. Its power of penetration is very slight and the pieces of tissue selected for fixation must be small. They should not exceed $2 \mathrm{~mm}$. in their least measurement, and thinner pieces are apt to give better results. Owing to the presence of asmic acid, Flemming's solution stains fat a dark-brown or black color, and may be nsed as a reagent for the identification of fatty substances.

Tissues should be left in Flemming's solution for about twentyfour hours, though twice that length of time would cause little if any harm. They must then be thoronghly washed in runing water for twenty-four lours or longer, and hardened in alcohol. Since Flemming's solution is usually employed for the study of the individual cells, it is desirable to prepare very thin sections of the tissues that have been hardened in it. For this purpose embedding in paraftin is the best methorl.

The foregoing fixing solutions will meet most of the requirements of the practitioner of medicine, lut it frequently happens that he 
would like to obtain speedy results from a microscopical examination without running the risk of loss of material of of poor results. When this is the case he may use absolute alcolol as a fixing-agent, thus taking advantage also of its ability to harden tissues and fit them for rapid embexlding in collodion or paraffin.

7. Absolute Alcohol.-If fiesh tissues are placed in strong alcohol, say 95 per cent., they are hardened; but during the process there is an opportmity for the albuminons fluids in the tissnes to escape to a certain extent, and for shrinkage to take place in consequence. If absolute aleohol be employed, it eauses such rapid coagulation that this leaching of the tissues loes not take place. It is necessary, however, that the alcohol should remain of nearly its original strength, otherwise the water in the tissues will dilute it sufficiently to destroy this coagulating action.

An excellent means for maintaining the strength of the alcohol is to keep a layer of anhydrous snlphate of copper in the bottom of the vessel. Crystals of cupric sulphate have a deep-blue color and contain 36 per cent. of water of crystallization which can be removed by heat; the anhylrous salt has a dirty white color. Both the anhydrous and the hydrated salt are insoluble in alcohol. If, then, crystals of eupric sulphate are heated in an oven until the blue color disappears, and the resulting anhydrous salt is brought in contact with aleohol, any water which the latter may contain will be removed. When the sulphate has become hydrated, its deep-blue color will be restored. It may then be removed and the water again expelled by heat. Care should be taken to allow any finely divided sulphate to settle completely to the bottom of the jar before the supernatant alcohol is used, lest particles come in contact with the tissnes immersed in the alcohol. 'Take a small jar with a tightly fitting cover (a musxum jar, holding six or eight ounces, will answer). Place the anliydrous cupric sulphate in the bottom and then mearly fill with absolute alcohol. When all the sulphate has settlerl, a few pieces of crmmpled filter-paper are placed upon it and overlaid with a smooth piece placed so as to slant a little. The latter slould lie near the surface of the alcohol, lout be wholly submerged. Small piees of the tissue to be fixed are placed upon the filter-paper where they will be covered by the alcolod. The alcohol inmediately coagulates the albuminous substanees on the surface of the pieces and then gradually replaces the water in the specimen, coagulating the deeperseated albumins as it penetrates the tissues. The expelled water 
sinks to the bottom of the jar owing to its greater specific gravity, and is at once taken up by the copper sulphate.

It will be seen that this method not only fixes the tissnes, but also quickly dehydrates then. The real dehydrating-agent is, however, the enpric sulphate, the alcohol serving merely as a vehicle for conveying the water from the specimen to that salt. If the pieces of tissue are small, not over $5 \mathrm{~mm}$. thick, they will be hardened by remaining in the absolnte alcohol over night, and mounted sections may be ready for examination by the next afternoon.

8. Fixation by Boiling.-Throw small pieces of the tissue, not larger than $1 \mathrm{~cm}$., into boiling 0.75 per eent. salt solution. Keep them at the temperature of boiling for two minutes. Then throw them into eold water. They may then be eut with the freezingmicrotome, or may be placed in 70 per cent. alcohol for hardening. This method is excellent for the detection of albuminons exudates within the tissnes, but it eauses so much shrinkage that it is not useful for general purposes.

Reference to the literature reveals a great number of formulx for fixing solutions. These formulie are nearly all empirieal, and not based on any clearly defined knowledge of the utility of the various ingredients. Of late years there has been a growing tendency to use acetie acid in the preparation of these fluids, and the mode of action of their different constituents has received careful attention. It appears that acetie acid may be nseful in two ways: first, by virtue of its rapid penetration; and, second, becanse it renders the proteid substances in the tissmes eoagulable by other constituents of the fixing solution-e.g., potassium bichromate, which, in nentral mixtures, does not of itself coagnlate these substances. If these conclusions be correct, the addition of acetic acid to Müller's fluid should make it a more valuable fixing solntion, and its action would then be as follows: the acetic acid penetrates rapidly and kills the cells; it also renders the proteids coagulable by the bichromate of potassimm. The latter salt penetrates lout slowly, and at first acts in very slight eoneentration, not sufficient to cause gross coagulation, but nevertheless enters into a combination with the proteids which, as the process goes on,

${ }^{1}$ A jar of absolute aleohol, prepared as above, may be used for the purposes of fixing or hardening until the sulphate of copper has become of a deep-blue eolor, or the alcohol so impregnated with dissolved fat that the latter interferes with embedding in celloidin. When the latter is the case, the hardened celloidin is opaque or opalescent. 
renders them insoluble. Similar events occur when Flemming's solution is used for fixation, but here the osmic acid also enters into some form of combination with the proteids and fats. It is not unlikely that Orth's fluid owes its value in part to the formic acid which formalin contains as the result of oxidation of the formaldehyde; this acid having an action similar to that of acetic acid. These recent analyses of the action of fixing solutions tend to render many of the old formulie superfluons. Probably, all that is desirable may be obtained by the use of three fixing solutions: first, Flemming's solution, which fixes admirably, but penetrates with difficulty owing to the slow diffusion of the osmic acil, and renders the tissues relatively refractory to dyes; second, a formula containing potassium bichromate or corrosive sublimate and acetic acid, such as Zenker's fluid, which penetrates well and leaves the tissues in a condition favorable for staining; third, diluted formalin to which about 5 per cent. of acetic acid has been added. This solution penetrates relatively larger pieces of tissue rearlily and does not weaken their affinity for dyes, but the fixation of the tissue elements is less perfect owing to the comparatively slight coagulating action of the formalin.

\section{Methods of Hardening.}

Solutions of chromates, as Müller's fluid, will, after a time, confer a pretty firm consistency upon tissnes, and even render them brittle. Tissues fixed in corrosive sublimate are also very much hardened. But the usual practice is to harden specimens in alcohol after fixation. To obtain the best results this hardening should be done gradually, since immersion in strong alcohol is apt to produce undesirable shrinkage, affecting the various tissue-elements in different degree.

Seventy per cent. aleohol (736 ce. 95 per eent. alcohol to $264 \mathrm{cc}$. water) is weak enough to begin with. A fter the tissues have been in alcohol of that strength for twenty-four to forty-eight hours, according to the size of the pieces, they are placed in 80 per cent. alcohol (842 ce. 95 per cent. alcohol to 158 ce. water) for an equal length of time, and then in 95 per cent. alcoliol. From the 95 per cent. alcohol they are placed in absolute alcohol, if it be desired to embed them in either eollodion or paraffin. If they are not intended for immediate use, they may be kept indefinitely in 80 per cent. alcohol.

During the hardening it is best not to allow the tissues to rest on the bottom of the vessel containing the alcohol, as they are 
liable to slight maceration in the alcohol, diluted with water from the specimen. They can be kept off the bottom by meams of a little crmmpled filter-paper. Specimens that have been fixed in a ehromatic solution shonld be kept in the dark while being hardened; those that have been fixed in corrosive sublimate should be hardened in alcohols to which a little tincture of iodine (sufficient to give them a sherry color) has been added. When absolute alcohol is used, its strength should be maintained by contact with quicklime (see directions for fixing tissues in absolute alcohol).

\section{Methods of Impregnation.}

When tissues are so porous or friable that sections are likely to tear or disintegrate it is desirable to impregnate them with some embedding-material. The most useful substances for this purpose are collodion, or celloidin, and paraffin. Whichever of these is used, it is necessary to remove the water from the specimen before the impregnation ean be accomplished, for both collodion and paraffin are insoluble in water. Tissues that have been hardened in alcohol are to a certain extent already dehydrated. The residnal water may be removed or reduced to a trace by treatment with absolute alcohol, in which eollodion is soluble.

The "celloidin" manufactured by Schering is an excellent preparation of gun-cotton, but almost equally good results may be obtained by using the more economical soluble cottons employed by photographers. Two solutions in a mixture of equal volumes of ether and absolute aleohol (both, if possible, of Squibb's preparation) should be kept in stock: one, a weaker solution, having abont the consistency of thin mueilage; the other, a stronger solution, resembling a syrup.

Collodion is soluble in abolute aleohol, so that tissues containing only that fluid are rearly for impregnation without further preliminary treatment. When thorough impreguation is desired the tissues should be immersed in equal parts of ether and absolute alcohol for a few days, and then in the weaker solution of celloidin or collorlion for a number of days or weeks-the longer the better ${ }^{1}$ but such complete impregnation is often mnecessary, and soaking for a day or two will often suffice if the sections to be made need not be very thin. It is not possible, in any event, to make very thin sections

I Impregnation may he greatly hastened if done at the body-temperature in a hermetically closed vessel. 
from tissues embedded in colloidin; but sections of large area may be obtained, which is often of greater importance. For very thin sections it is better to use paraffin for the embedding-material, although the resulting sections will have to be smaller.

Paraffin is insoluble in alcohol of all strengths. It is therefore necessary to remove the ahsolute alcohol from the tissues before they ean be impregnated with paraffin. This may be done by immersing the tissues in some liquid that is a solvent for paraffin and is also miscible with alcohol. For this purpose, xylol, chloroform, or oil of cedar-wood may be used. Xylol yields the most rapid results, but its use is emontraindicated when it is desired to retain fatty substances that have been colored with osmic acid, as the xylol extracts them. If their preservation within the tissues is important, chloroform should be used; but the sojourn even in that liquid should be as short as possible. Oil of cedar-wood probably canses less change in tissues than chloroform, but the method is more protracted, and, requiring longer treatment in the paraffinoven, probably has little ultimate advantage over chloroform for general purposes.

If xylol is used, the tissues are transferred from the absolute alcohol to xylol, on which they at first float. Subsequently they sink, and are gradually rendered transparent as the alcohol is expelled by the xylol. When there are no opacities left the specimen is ready for the paraffin-oven. These changes take from two to twenty-four hours.

The treatment with chloroform is similar to that with xylol, but after the tissues have been eleared in ehloroform (six to twenty-four hours) they are immersed in a saturated solution of paraffin in chloroform for about the same length of time. They are then ready for the paraffin-oven.

When oil of cedar-wood is used the picees shonld be soaked in two suceessive portions of the oil, about twelve hours in each, to insure removal of the alcohol.

The forecoing steps are all preliminary to the actual impregnation with paraffin.

It is important that the paraffin used for impregnation and embedding should have a wax-like, and not a crystalline, texture, and that its melting-point should be such that it consisteney will be favorable for cutting at the average temperature of the laboratory. Grübler, of Leipzig, furnishes excellent qualities of paraffin. 
For a room-temperature of $20^{\circ} \mathrm{C} .\left(68^{\circ}\right.$ Filh. $)$ a variety melting at $50^{\circ}$ C. $\left(122^{\circ}\right.$ Falh.) will give good results. If the laboratory is warmer, a paraffin of higher melting-point should be used.

Impregnation is aceomplished by placing the bits of tissue in a batl of melted paraftin maintained at a temperature only slightly above that of fusion, say $52^{\circ} \mathrm{C} \cdot\left(125.6^{\circ} \mathrm{Fah}\right.$.), if the paraffin melts at $50^{\circ} \mathrm{C}$. $\left(122^{\circ} \mathrm{Fah}.\right)$. This may be accomplisherl in a waterjacketed oven provided with a thermoregulator, or upon a plate of brass or copper, resting on a tripod and heated at one end by a burner. When the latter method is employed the paraffin is melted in a little glass dish, which is moved along the plate until a point is found at which the paraffin remains melted at the bottom, but is covered at the edges of the surfice with a thin layer of congealed paraffin.

The length of time that the specimens should remain in the melted paraffin will vary with the character of the tissues and the method of getting rid of the alcohol which has been employed. It should not be protracted longer than necessary for eomplete impregnation, as heat is injurious to the tissues. When xylol has been used two hours will usually suffice, especially if the pieces of tissue are transferred to a fresh paraffin-bath after about an hour. This renewal of the paraffin is still more important if oil of cedar-wood has been used. Chloroform requires about the same time as xylol, and the tissues should be transferred to fresh paraffin once or twice.

When impregnation has taken place and the final bath of paraffin no longer has the slightest odor of the clearing-agent, the pieces of tissue are removed from the bath with warmed forceps and are ready for immediate embedding (vide infia), or may be placed on smooth writing-paper, to which they adhere. A designation of the specimen may he written on these papers, and the tissues kept in this condition until required for cutting. They then are embedded.

\section{Methods of Embedding.}

The olject of embedling is to surround the piece of tissue from which sections are to be ent with a mass of the embedding-substance, which then not only supports the tissue when it comes in contact with the knife, but also affixes it to a block or other support which can be fitterl into the elimp of the microtome.

Microtomes designed for cutting paraffin usually have special 
supports for the embedded speeimen, but blocks of hard wood may be nsed in their place.

For the support of tissues embedded in collodion blocks of plateglass are probably both better and cheaper than those made of other materials. They may be easily prepared from waste pieces of plateglass, about a quarter of an inch thick, and "obscured" or ground on one surface. The glass may be eut into blocks of any desired size by scoring the smooth side with a diamond and then splitting the pieces apart with a sharp blow from a wedge-shaped hammer. The embedded speeimen is affixed to the rough surface of these blocks by means of collodion, and the blocks may be numbered with a lead pencil upon the rough surface. The writing will be preserved from obliteration by the specimen subsequently placed upon it, and can be read through the glass.

1. Embedding in Collodion (or Celloidin).-Tissues of firm consistency and moderately uniform structure, such as liver, kidney, and the majority of tumors which have been hardened, may be embedded without previous impregnation. Before this can be done, however, they must be either dehydrated with absolute alcohol, or soaked for a few hours in a mixture of equal volumes of ether and alcohol $(95$ per cent. alcohol will answer, if absolute alcohol is not to be had). For this mapid method the bottom of the piece of tissue must be flat and parallel to the plane of the desired sections. When the neessary trimming of the specimen is completed moisten it with absolute alcohol or the etheralcohol mixture, then dip it in the thick solution of gun-cotton and place it at once upon the ground surface of the glass block (previously labelled). In a few minutes the collodion will have evaporated sufficiently for the formation of a distinet pellicle upon its surface. When this has become firm enough to withstand gentle pressure immerse the block and specimen in several times their volume of 80 per cent. alcohol. This will harden the collodion, and in the course of a few hours the specimen will be ready for cutting.

Tissues impregnated with collodion had best be embedded by a slower process than the foregoing, although that method will answer where only a slight support of the tissue-elements within the specimen is needed. A gradual concentration of the collodion within the tissues may be brought about in the following manner:

Smear the inside of a small, straight-sided glass dish with a trace of glycerin and then fill it with enough moderately thick collodion 
to cover the pieces of tissue with a layer about one-quarter of an inch deep. Now place the specimens that have been in thin collodion in the dish, with the surfaces from which sections are to be cut resting on the bottom. Place the dish in a larger vessel with higher sides and loosely cover the latter. The ether and alcohol in the collodion will gradually evaporate, and their vapors will first fill the outer vessel and then overflow its sides. The depth of the outer ressel keeps these vapors in contact with the surface of the collodion, preventing the formation of a pellicle, which would retard evaporation and also favor the formation of bubbles in the collodion. After an interval of one or more days the collodion will have a gelatinous consistency. It should be allowed to become so hard that it has considerable firmness, but is still soft enough to receive an impression of the ridges in the skin when pressed with the finger. The outer vessel is then partly filled with 80 per cent. alcohol so that the whole of the inner dish is submerged.

By the next day the collodion will be hard enongh for removal from the dish. With a small sealpel, held vertically, divide the hardened mass of collodion into portions, each of which contains one of the pieces of tissue (for several pieces may be embedded in the same dish, provided care be taken to preserve their identity). Remove the pieces and trim down the collodion around the specimens, leaving a margin of about an eightl of an inch. Trim the top surfaces of the collodion parallel with the bottom surfaces, then dip the trimmed surface into a little absolute alcohol contained in a watch-glass, in order to dehydrate it. This will take about two minutes. Label glass blocks with lead-pencil, place a drop of thick collodion on the writing, and transfer the embedded specimens immediately from the absolute alcohol to the drop of collodion, pressing it into contact with the glass. When a good pelliele has formed on the collodion drop the whole block into 80 per cent. alcohol. If the block of hardened collodion containing the specimen be sufficiently deliydrated on the surfaces coming in contact with the drop of collodion, and the latter have not time for the formation of a pellicle before it recives the block, there will be no difficulty in cementing the emberded specimen to the roughened surface of the glass. It is best not to cut sections until the day after the specimen has been affixed to the glass block. These blocks, with attached specimens, may be preserved indefinitely in 80 per cent. alcohol. 
The thin coating of glycerin on the inside of the embedding-dish serves the purpose of preventing the collodion from sticking to the glisss.

2. Embedding in Paraffin.-The specimen should first be trimmed so as to have one surface parallel to the plane of the future sections. This trimming had best be done bofore the specimen is placed in the first paraffin bath. When specimens are to be embedded directly from the paraffin bath, the simplest method is to employ a small box made from rather heavy writing-paper by folding it in the following way (Fig. 260): Suppose the box is to be 2 inches long, 1 inch

F:G. 260.

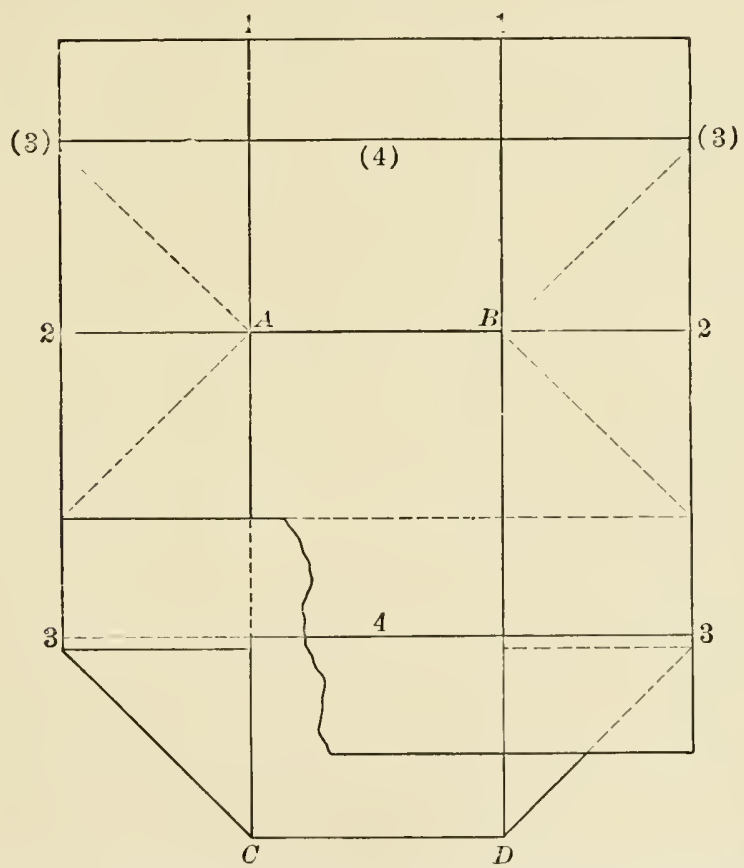

The upper half of the diagram represents the ereases in the paper which are produced by folding; the lower half shows the last fold on the right and the next to the last on the left. The bottom of the box is the rectangle $A, B, C, D$.

wide and $\frac{3}{4}$ inch deep. Cut a piece of paper $2 \frac{1}{2}$ inches wide (= width of box + twice its depth) and $4 \frac{1}{2}$ inches long (= length of box + twice its depth +1 inch to allow $\frac{1}{2}$ inch fold at each end). Crease the paper, longitudinally, $\frac{3}{4}$ inch from and parallel to the edge by folding and pressure (folds 1-C and 1-D). Then open these 
foids and flatten the paper again. Next, make a transverse fold $1 \frac{1}{4}$ inch from one end of the paper (folds 2-2, also partly represented by C-D), and then fold in the corners so that the creases make angles of 45 degrees with the edges of the paper (folds 3-C and 3-D). When this has been done, make the fold + by tuming down the free edge of the paper so as to keep the corners in place. Treat the other end of the paper in the same way. The folded edge 4 and its counterpart (4) can now be drawn apart and, after a little manipulation, the box will assume its final shape. This box is nearly filled with melted paraffin kept fluid by placing the box on top of the paraffin oven. The bits of tissue are placed in the paraffin with the surfaces from which sections are to be made resting upon the bottom of the box. The pieces of tissue should not touch the sides of the box. During these manipulations the forceps should be kept warm enough to keep the paraffin melted. When the tissues are in proper position the box is floated on cold water, which rapidly ehills the paraffin. When cold, the paper can usually be readily stripped from the block of paraffin. If there is any diffieulty due to a softening of the paper by water, drying will restore a sufficient firmness to the paper. It is important that the paraffin should cool rapidly, and that enough should be originally placed in the box more than to cover the specimens completely, as some shrinkage takes place on cooling. If more than one specimen is embedided in the same box, they should be well separated from each other, so that irregular cleavages of the paraffin when it is subdivided may not bring the surfices of the individual blocks too near the embedded specimen. A little study of the method of folding paper to make boxes will enable the reader to make a box of any desired dimensions.

If the specimens to be embedded have previously been impregnated with paraffin and then preserved on pieces of paper as described ahove, any excess of paraffin upon the speeimen may be removed by placing it on a piece of filter-paper and warming it gently until the superfluous paraffin is absorberl by the paper. The trimmed surface is then laid upon a small glass plate that has been smeared with a mere trace of glyeerin, and metallic right-angles, similarly smeared on the inside, are placed around the speeimen in such a way as to form a box with a clear space at least an eighth of an inch broad between its sides ind the speeimen. Melted paraffin, at a temperature only slightly exceeding that necessary to keep it fluid, is then poured into the box, filling it. The paraffin should now be made to cool 
as rapidly as possible, in order to provent its becoming erystalline. For this reason it is well to propare the box formed by the plate of glass and the metallie right-angles in the bottom of a deep soupplate or some similar vessel. After the box has been filled with melted paraffin cold water may be poured into the plate until its surface is nearly on a level with the top of the box, and when the top of the paraffin las congealed the plate may be filled with eold water. After a few minutes the box may be taken apart and the block of paraffin left in the water to beeome cold.

These paraffin-blocks may be labelled with a needle and kept indefinitely in the dry condition, at a temperature below that at which the paraffin softens. When they are to be used the bottom of the block should be trimmed parallel with the top, suffieient paraffin being removed to obliterate the hollow which formed when the paraffin solidified. This trimmed surface is then made to adhere to the paraffin-support of the microtome, or a block of hard wood, by means of a heated sealpel.

It often happens that little air-bubbles are present in the paraffin close to the specimen, or that cracks exist between the specimen and the surromding paraffin, owing to the retention of a little air at the time of embedding. 'These defeets can be remedied by melting the paraffin with a heated needle. It is important that the paraffin should everywhere he in perfect eontact with the specimen. When this repairing, if necessary, has been done and the paraffin has become cold again, the block should be trimmed so that the specimen, or at least its upper part, is contained in a little eubical mass resting on the main block, with a margin of paraffin, abont $1 \mathrm{~mm}$. thick at the places where the edges of the eube are nearest to the specimen. Those edges should be straight and at right angles to each other, and the sides of the trimmed cube should be vertical. In trimming the block only thin slices should be removed at a time, in order to avoid cracking the paraffin forming the small cubical mass enelosing the specimen.

These manipulations prepare the specimen for eutting.

\section{Methods of Cutting.}

It is possible to obtain useful sections from fresh or hardened tissnes by free-hand cutting with a sharp razor ; for this purpose the razor should either be very hollow ground, so as to have a thin blade, or the lower surface should be ground flat. In stropping 
the razor, or microtome-knife, the stroke should be from point to heel during both the forward and return motions. In entting, the edge should be used from heel to point, and this same motion should be used in honing. A wire arrangement is usually furnished with microtome-knives, which is intended for use while honing or stropping. It serves to raise the back of the knife when the flat side is sharpened, and should always be employed. Care must be taken not to press the knife against the strop, as this is liable to turn or blunt the edge. A few light strokes on the strop immediately after each day's nse will keep the knife sharp and eoat it with a little grease, protecting it from rust. A mierotome-knife should never be allowed to rest with its edge on any hard surfuce; the mere weight of the knife is sufficient to spoil its edge.

In entting free-hand sections of fresh tissues the upper surface of the razor should be kept flooded with normal $(0.75$ per cent.) salt solution. The sections float in this fluid and are kept from tearing. Each section should be removed by a single stroke of the razor. When hardened speeimens are eut, 80 per eent. alcohol should be used instearl of salt solution.

Free-hand sections cannot be made either so thin or uniform as sections prepared with a microtome, and these instruments are now so eheap that they are universally used. There are three prineipal forms : 1, freezing-mierotomes; 2, paraffin-mierotomes; 3 , mierotomes for cutting sections of tissnes embedded in collodion. The last are often fitted with attachments intended for use in eutting frozen sections, and can also be used for paraffin. But the best results are obtained by using instruments especially designed for each purpose.

1. Frozen Sections.-Freezing is usually employed when seetions of fresh tissues are to be made, but hardened tissnes may be eut with a freezing-mierotome if the alcohol be first removed by soaking for a considerable time in water. The tissue may be placed upon the plate of the microtome in a little water or nentral salt solution; but a better method is first to soak the tissue in a syrupy solution of gum-arabie, and to moisten the plate with the same before freezing. This solution freezes in less coarsely erystalline form than water or salt solution.

When the tissnes are frozen, thin seetions are removed with a quick forward and slightly oblique stroke of the knife. The motion is intermerliate between that of a plane and a single stroke of a saw. 
The sections are floated from the knife in a dish of water or normal salt solution; or they may be fixed in a 4 per cent. solution of formaldehyde. The frozen tissue must not be too hard. Should that be the case, the upper surface may be moistened by means of a camel's-hair brush, dipped in water or salt solution, or warmed with the breath.

2. Collodion-sections.-The block upon which the embedded specimen is fistened is secured in the clamp of the microtome in such a position that the sections will be made in the desired plane. The knife is then adjusted on its earrier in an oblique position, so that the greatest possible length of its edge will be utilized in cutting. The upper surface of the knife is flooded with 80 per eent. alcohol, and slices are removed with the knife until the desired level of the specimen has been reacherd. Sections are then made as thin as is compatible with obtaining complete sections from the whole surface. The sections float in the 80 per cent. alcolol, with which the knife should be kept flooded, and may be removed with a camel's-hair brush. At no time should either the knife or the specimen be allowed to dry. The sections may be kept indefinitely in 80 per cent. alcohol, or they may be dropped into water if they are to be used within a short time.

After use, the knife should be carefully wiped, stropped, and placed in its case. The microtome should be dried and the tracks moistened with a little oil of sweet almonds or paraffin oil, to prevent rusting.

3. Paraffin-sections. - The knife should be fixed perpendicular to the direction of eutting, its edge acting like that of a plane. Its surfaces must be clean and dry; adherent paraffin can be removed with a cloth moistened with xylol.

The paraffin-bloek containing the specimen to be cut is firmly clamped with one of its narrow edges parallel to the edge of the knife. The block is now raised and moderately thick slices removed until the desired level is reached, when the thin sections desired may be cut. It not infrequently happens that the sections roll before the edge of the knife. This is probably due to the paraffin being too hard. In that case the cutting should he done ir a warmer room, or a lamp or Bunsen burner may be placed within a foot or two of the face of the paraffin block. This rolling will, however, cause little trouble in the use of the sections unless it be desired to have them adhere to each other at the edges to form ribbons, in which the succession of the sections is preserved. If the 
sections are compressed into tiny folds or ridges, the paraffin is too soft and the block must be somewhat chilled.

Before paraffin-sections can be stained it is necessary to remove the paraffin. If the tissues are sufficiently coherent, this can be done by dropping the sections into xylol or chloroform; but if this wonld eanse a disintegration of the sections, they must be affixed to slides or cover-glasses by means of a cement which shall hold the different parts of the tissues in their proper relative positions after the paraffin has been removed. The simplest cement for this purpose is Maver's albumin mixture, prepared as follows : beat up the white of an egg and allow the froth to liquefy. Then add an equal bulk of glycerin and a few pieces of camphor (for the preservation of the mixture). This cement is applied to the clean surface of a slide, or eover-glass in a very thin layer with the side of a camel'shair brush, eare being taken to leave no air-bubbles. The paraffinsections are removed from the knife with a fine camel's-hair brush or a small, but rather stiff feather inserted into a handle, and placed upon the coating of cement. They are then flattened out with the brush or feather and pressed against the glass to remove superfluous cement. If the seetions have rolled, unrolling will be facilitated by warming the sections with the breath. The coverglasses are set aside to dry a little, and are then heated to render the albumin insoluble. This requires some pratice. The manipulation is intended to accomplish the following results: the paraffin melts at a lower temperature than that at which the albumin is coagulated, and this fact is utilizerl to remove all exeess of the cement, which is washed away from the tissues by the flow of melted paraffin. The residual albumin is suffieient to make the section adhere to the glass when subjected to a high enongh temperature to eanse its coagulation. The albumin should be dried to a considerable extent before it is converted by the heat into its insoluble form, otherwise it will eoagulate in opaque masses. To bring about the desired results the cover-glase, held in a pair of foreeps, is waved over a flame until the paraffin is seen to melt. That temperature is maintained for a few moments, and then the eover-glass is heated until valpors are distinetly seen to rise from its surface. Great care must be taken not to seorch the sections. When the sections have been cemented to them the cover-glasses are placed in absolute alcohol to dehydrate them, and are then treated with xylol, chloroform, or some other solvent of paraffin. The solvent is then 
removed by another bath of absolute alcohol, and the alcohol removed by water, when the sections are ready for staining.

It is, however, much more convenient to haundle paraffin sections. when they adliere to each other at thcir edges to form ribbons. With a paraffin microtome a little practice will enable one to secure these ribbons without difficulty and of almost any desired length. The ribbon may be carefully laid on the surface of perfectly clean water having a temperature of $40^{\circ}$ to $43^{\circ} \mathrm{C}$, where the paraffin will become softened and the ribbon will then flatten out upon the water. While it is floating on the water the ribbon may be cut into lengths with scissors, slicles coated with Mayer's albumin mixture slipped under them, and then slide and ribbon removed together and drained. The slide may then be dried upon or within the paraffin oven, when the sections will adhere to the glass.

When the sections do not require affixing to slides or cover-glasses they may be dropped into the solvent for the paraffin, and the latter removed with absolute alcohol, for which water is then substituted, preparing the seetions for staining. It sometimes happens that when sections are transferred from absolute alcohol to water the diffusion-currents are so strong that the sections are destroyed. When this is the case the transition must be made more gradually, baths of 80 per cent., 50 per cent., and 30 per cent. alcohol being interposed between the absolute aleohol and the water.

\section{Methods of Staining.}

A large number of methods have been devised for bringing out the strueture of tissues. Many of the methods are of almost universal application, white others require special methods of fixation or other preliminary treatment of the tissues. Some are ealculated to render the general features of struc aure more evident than they wonld be if the tissues were not stained; others stain certain elements some characteristic color, and, to that extent, serve the purpose of microchemical reagents. Only a few of the more useful methods ean be deseribed here; for others the reader is referred to the iarger text-books and the technical journals.

Sections cut in paraffin and affixed to slides may be stained by flooding the slide with the filtered dye, but it is preferable to use tumblers of small diameter or Coplin jars into which the dye has been filtered. The slides are then placed upright in the stain. Similar vessels ean also be used for the alcohol, xylol, ete., used in 
preparing the sections for mounting. Loose sections can be stained, etc., in porcelain butter dishes, being transferred with a bit of platinum wire fused at one end into a glass rod. Such needles can be readily bent to any desired shape and may be cleansed hy passing through a flame.

1. Hæmatoxylin and Eosin.-Hiematoxylin, the coloring-prineiple of logwood, has proved a very useful stain for the nuclei of cells. It is not a pure nuelear stain, but also tints the cytoplasm of cells and the intercellular substances. It is most commonly employed in combination with alum. Such combinations of coloring-matter with a base are called "lakes."

A hæmatoxylin-lake may be used alone, or its use may be preeded or followed by the employment of a counterstain with some diffuse color not affecting the nuclei. For counterstaining, eosin or neutral carmine is usually emploved. Both stain the tissues a diffuse red, varying in depth according to the nature of the tissue-elements in the section.

There are several formulæ for the preparation of alum-hæmatoxylin, but that devised by Böhmer will answer all purposes, and is very simple:

1. Hæmatoxylin crystals, Absolute alcohol,

2. Alum, Distilled water,
1 gram.

$10 \mathrm{ce}$.

20 grams.

200 ce.

Cover the solutions and allow them to stand over night. The next day mix them and allow the mixture to stand for one week in a wide-mouthed bottle lightly plugged with cotton. Then filter into a bottle provided with a good cork. The solution is then ready for use. Nearly all solutions of alum-hæmatoxylin require an interval of time for "ripening," and their staining-powers improve with age.

Alum-hrematoxylin is intended for staining sections from tissues that have been fixed and hardened. It is especially useful when the fixing-solution employed contained chromates, but may be used after almost any method of fixation, if the time of staining is of the right length and the sections are previously freed from acidity by thorough washing.

If the following directions are clowely adhered to, the student 
can hardly fail to obtain good results with the use of Böhmer's hiematoxylin :

Transfer the sections from the 80 per cent. aleohol in which they have been kept to a dish of distilled water. At first they will float on the surface of the water ; this is a favorable moment for removing all folds and wrinkles. The sections should be manipulated with platinum needles, prepared by fusing a bit of platimum wire into the end of a grass rod. Such needles ean be cleaned by heating the wire red in a flame.

When the sections sink to the hottom of the dish of water, and remain there, it may he assumed that they are free from alcohol.

Filter about $5 \mathrm{cc}$ of the hematoxylin into a watch-glass or butterdish and transfer the seetions from the water to the dye.

Let the sections stain for three minutes loy the watch, and then transfer them to a dish of distilled water. At first the sections will have a reddish tint, but as the washing proceeds the color will turn to a pure blue. During the washing the water should be renewed, until finally it acquires no color from the sections and the latter have lost all traces of a red tint. This washing may take several minutes, or even a few hours; but if good, permanent stains are desired, it is of great importance that it be thorough. This washing completes the actual staining with hrematoxylin, and the sections are then ready for counterstaining with eosin or for dehydration.

The eosin solution used for diffuse staining is prepared by dissolving 1 gram of eosin in $60 \mathrm{ec}$ of 50 per cent. alcohol. Of this solution, about ten drops are added to $5 \mathrm{ce}$. of distilled water in a small dish; the sections are stained for about five minutes and then washed in distilled water. 'They are then ready for dehydration and mounting. The diluted eosin shonld be thrown away after use, but the hæmatoxylin can be filtered back into the stock-bottle.

Since the hrmatoxylin solution improves with age, no exact directions can be given as to the length of time sections should remain in a particular solution. Three minutes will usually yield good results; but if it is found that the color is too dark, a shorter time should be employed, and vice versâ. One soon beeomes familiar with the staining-powers of the particular solution used. The dishes that have contained hæmatoxylin should be washed soon after use, or may be subsequently cleaned with a little hydrochloric acid, all traces of which should then be removed by thorough washing in water. 
The above method for staining with hæmatoxylin and eosin is highly recommended for general routine work.

2. Neutral Carmine.-

Carmine, "No. 40,"

Distilled water,

Ammonia,
1 gram.

$50 \mathrm{ce}$.

5 “

The solution is allowed to remain exposed to the air until the odor of ammonia is no longer perceptible. It is then filtered into a bottle, where it is kept till needed.

Neutral earmine gives a diffuse stain, resembling that of eosin, but rather clearer in character. It is employed in a greatly diluted form, according to the following directions :

One drop of the neutral carmine is mixed with about $20 \mathrm{ec}$ of distilled water. A trace of acetic acid is then added by dipping a platinum needle into the acid and stirring the diluted dye with the acidulated needle. A piece of filter-paper is then placed upon the bottom of the dish, and the sections to be stained are transferred from distilled water to the dye and distributed upon the paper in such a way that they do not lie over each other. The dye acts very slowly, twenty-four hours being none too long for good results. If the staining be hastened by using a stronger solution, it suffers in sharpness. After staining, the sections are thoroughly washed in distilled water, and may then be subjected to a nuclear dye, such as hæmatoxylin. The proper acidulation of the diluted dye is of importance for the snecess of this method. If the solution is not sufficiently neutralized, the seetions will not be stained; if it is too acid, precipitation of the carmine will take place.

3. Alum-carmine.-

Alım,

Distilled water,

Carmine, "No. 40,"
5 grams.

100 ce.

2 grams.

The alum is dissolved in the water with the aid of heat, the carmine then added, and the mixture kept at the boiling-point for about half an hour. It is then allowed to cool and filtered into the stock-bottle. Two or three drops of deliqueseed carbolic aeid may be added to prevent the development of fungi.

Sections are stained in the umliluted, but filtered, dye for at least 
five minutes. There is no danger of over-staining. It is a pure nuclear stain, coloring the chromatin red. After staining, the sections are either washed, and are then ready for dehydration, or they may receive a counterstain with picric acid, coloring the tissues a diffuse yellow. This may be most readily aceomplished by adding a few small erystals of pieric acid to the first dish of dehydrating alcohol (see p. 313).

\section{Borax-carmine.-}

Borax,
Distilled water,
Carmine, "No. 40,
Alcohol, 70 per cent.,

\section{4 grams.}

$100 \mathrm{ec}$.

3 grams.

100 ce.

The borax is dissolved in the water by warming, and the solution allowed to cool ; the carmine is then stirred in and the alcohol added. After standing twenty-four hours the solution is filtered into the stock-bottle, a process that is exceedingly slow.

Borax-carmine is used for the staining of little masses of tissue before they are embedded. It is a nuclear dye, giving the chromatin a red color. It is useful when paraffin-embedding is to be employed and it is desirable to restrict the manipulation of the seetions to a minimum.

Small pieces of hardened tissues, not over $5 \mathrm{~mm}$. thiek, are transferred from distilled water to the undiluted dye and allowed to stain for twenty-four hours, or longer. After staining they are immediately placed in an acid aleohol, prepared by adding 5 drops of eoncentrated hydrochlorie acid to $100 \mathrm{ee}$. of 70 per cent. alcohol. The tissue should not rest on the bottom of the vessel containing the alcohol, but upon crumpled filter-paper, so that the extracted excess of coloring-matter may sink to the bottom. If the acid alcohol around the specimen becomes colored, fresh portions of alcohol should be used. The treatment with acid alcohol is continued until no more color is given off from the specimen. It is then transferred to 90 per cent. alcohol, in which it should remain for twentyfour hours, after which it ean be subjected to the dehydration necessary for embedling.

\section{Orth's Lithio-carmine.-}

Carmine, "No. 40,"

3 grams.

Lithiun earbonate, saturated aqueons solution, $100 \mathrm{ec}$. 
The solution of lithium carbonate is prepared hy occasionally shaking a mixture of distilled water and an excess of lithium carbonate. Twenty-four hours will suffice for the production of a strong enough solution. The supermatant liquid is then filtered. Carmine readily dissolves in this solution. For preservation a erystal of thymol may he added.

Lithio-earmine stains sections in abont five minntes, and there is no danger of overstaining. Like borax-camine, it requires aftertreatment with aeid aleohol. The seetions shonld be transferred, without intermediate washing, to 70 per cent. alcohol containing 1 per eent. of concentrated hydrochlorie aeid; they may then be dehydrated, and, if desired, counterstained with picrie acid during the dehydration.

6. Unna's Methylene-blue.-

Methylene-blue,

1 gram.

Potassium carbonate,

Distilled water,

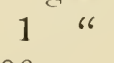

100 ce.

When required for use, this solution should be diluted with distilled water to one-tenth or one-twentieth of its strength. It gives excellent results when used to stain paraffin sections of tissues hardened in Zenker's fluid, especially when preceded by eosin. Stain half an hour in a 5 per cent. aqueous solution of eosin (Grübler's bluish); wash in rumning water; stain in the dilute methylene-blue until the red color is no longer visible; wash; differentiate in absolute alcohol till the sections appear pink (or violet, if there be many muclei in the tissne); clear in xylol and mount in damar or Canada bakam dissolved in xylol.

Upon long standing, this solution of methylene-blue undergoes chemieal changes whieh reduce its staining value when used as above, but it will keep for a number of months.

7. Aqueous Methylene-blue.-This is usually prepared at the time when needed by mixing one part of a saturated solution of the anilin-color in 95 per cent. alcohol with nine parts of distilled water. It is frequently employed as a general stain for bacteria.

Other anilin-colors, such as fuchsin, gentian-violet, methyl-violet, and Bismarck-brown, may be kept in concentrated alcoholic solution, to be diluted in a similar manner just before use. When these solutions are used for staining sections or eover-glass preparations the adherent dye is washed off' with water, after which the intensity 
of the stain is redued by the use of aleohel, gi per cent. or absolute, which bleaches the portions of the specimen which retain the color with the last tenacity. If the action of the alcohol he maintained for too long a time, the eolor may be discharged from all parts of the specimen. The method of overstaining a specimen, and then discharging the color from those parts where it is not desired, is a common one. The process of diweharging the color is called the "differentiation" of the stain, hecause it serves to distinguish those clements which hold the color strongly from those. which part with it easily.

\section{Carbol-fuchsin.-}

Saturated alcoholic solution of fuchsin,

$10 \mathrm{cc}$.

Acpueous solution of earbolic acid erystals, 5 per cent., $90 \mathrm{ec}$.

This solution should always be carefully filtered before use.

9. Anilin-gentian-violet.-A. Ehrlich's formula :

Saturated aleoholic solution of gentian-violet, $1.5 \mathrm{ce}$.

Freshly prepared anilin-water,

$8.5 \mathrm{ce}$.

The anilin-water is prepared by shaking a few drops of anilin with distilled water, allowing the mixture to stand for about ten minutes, and then filtering throngh well-moistened filter-paper. The filtrate should contain no globules of the anilin. In order to avoid this the filtration should be stopped before all the watery part of the mixture has run through the paper, otherwise oily drops of anilin will follow.

Precipitates are likely to oecur in this gentian-violet solution when it is first prepared. After twenty-four hours these are less abundant. The solution deteriorates soon after that time, and should not be used more than a week after its preparation.

B. Stirling's formula :

$\begin{array}{lr}\text { Gentian-violet, } & 5 \text { grams. } \\ \text { Alcohol, } & 10 \mathrm{cc} . \\ \text { Anilin, } & 2 \mathrm{cc} . \\ \text { Distilled water, } & 88 \mathrm{ce} .\end{array}$

This solution keeps better than the preceding. Both must be filtered carefully through moistened filter-paper immediately before being used. 
10. Gram's Solution. - This is a differentiating agent used in connection with anilin-gentian-violet:

Iodine,
Potassium iodide,
Distilled wates,
1 gram.

2 grams.

$300 \mathrm{ce}$.

The specimens are first overstained with the gentian-violet solution. They are then washed in water and placed in Gram's solution for from three to five minutes. While in this solution they turn a brown color, and the combination between the coloring-matter and some of the elements of the specimen is loosened. The specimen is then transferred to 95 per cent. alcohol, in which it remains until no more color is given off. If sufficient color has not been removed, the treatment with Gram's solution and alcohol may be repeated. After this differentiation the speeimen may be dehydrated, eleared, and mounted; or a contrast-stain may be used before those manipulations. This is a useful method for staining hacteria in sections of tissue when the species of hacteria are such as resist the decolorizing action of the iodine. In this respeet different species of bacteria differ greatly, and the method is commonly employed in bacteriologieal work to distinguish those speeies which retain the stain, or are "positive to Gram," from those which are decolorized or "negative to Gram."

11. Van Giesen's Picric Acid and Acid Fuchsin Stain.-

Aqueous solution of acid fuchsin, 1 per cent., Saturated aqueons solution of pierie acid,

$5 \mathrm{ce}$.

100 “

This solution serves to stain fibrous intercellular substances. It is used in the following manner:

1. Slightly overstain with alum hæmatoxylin; e.g., Böhner's hamatoxylin.

2. Wash thoroughly in distilled water.

3. Stain in Vin Giesen's dye for five minutes.

4. Wash in water.

5. Dehydrate in 95 per cent. aleohol.

6. Clear in oil of origatnum.

7. Mount in xylol-balsam or xylol-1lammar.

The tissues should have been fixed in a corrosive-sublimate solution or one containing chromates; e.g., Müller's fluid, 'Zenker's 
fluid, or sublimate solution. The connective-tissue fibres are stained red by the acid fuehsin. The reason for overstaining with hamatoxylin is that subsequent troutment with pieric acid discharges some of that color.

12. Benda's Iron-hæmatoxylin Stain.-This is a powerful stain well adapted to the staining of paraffin-scetions that have been affixed to eover-glasses. It stains nuelei and intereellular substances, as well as the protoplasm of cells, various shades of gray, and the color is very permanent. The ontline of the method is as follows :

1. Mordant the seetions (after affixing to cover-glasses, if that method is used) in a mixture of equal parts of liquor ferri sulfuriei oxydati of the German Pharnacopoeia and distilled water for twenty-four hours.

2. Rinse in distilled water, and then wash in three changes of tap-water.

3. Stain in aqueous solution of hæmatoxylin, prepared by mixing 10 drops of a concentrated alcoholie solution of the crystals with $10 \mathrm{ec}$. of distilled water. Stain for from one-half to twentyfour hours.

4. Rinse in distilled water.

5. Differentiate in equal parts of glacial acetic aeid and distilled water.

6. Wash thoroughly in distilled water.

7. Dehydrate in absolute aleohol.

8. Clear in xylol, carbol-xylol, or some essential oil.

9. Mount in balsan.

13. Pal's Modification of Weigert's Stain for the Medullary Sheath of Nerves.-This method is useful for the study of the central nervous system, and may, with advantage, be preceded by staining with nentral carmine. The tissues should have been fixed in a chromate solution; e.g., Miiller's fluid.

1. Soak sections several hours in 1 per cent. ehromic aeid solution in water.

2. Stain twenty-four to forty-eight hours in :

Hematoxylin erystals,

Absolute alcohol,

1 gram,

Lithium carbonate (saturated aqueous solıtion), 7 "

Distilled water,

90 "6 
The hymatoxylin crystals may be disoolved in the alcohol and the solution kept in stock, the proper proportions of lithium earbonate solution and water being added at the time of nse.

3. Wash in water to which a little lithim earbonate solution has been added (about 2 ce. to each $100 \mathrm{cc}$. of water). The sections should acquire a deep-blue color.

4. Differentiate in 0.25 per cent. solution of potassium permanganate in distilled water, till the gray matter-e.g., of the spinal cord-becomes brownish-yellow (one-half to five minutes).

5. Decolorize the gray matter in the following solution :

Oxalic acid,
Potasinm sulphite,
Distilled water,

6. Wash thoronghly in distilled water.

7. Dehydrate in 95 per cent. aleohol.

8. Clear in carbol-xylol, oil of bergamot, or oil of origanmm.

9. Momnt in xylol-balsam or xylol-dammar.

This method stains the myelin-sheaths of the medullated nervefibres a dark blue, nearly black, color. If it has been preceded by a stain with neutral carmine, the axis-cylinders of the nerve-fibres will be stained red, and the nuclei of the nerve-cells will also appear red.

14. Golgi's Methods.-These method- have yielded most excellent results in the study of the eentral nervous system, the distribution of the peripheral nerves, and the delicate terminations. of the duets of glands; e.\%., the bile-capillaries. The methods. must be regarded as special procedures in such studies, and can but be referred to here. They all depend upon hardening in some chromium salt, with or without the addition of osmic acid, and the subseqnent impregnation with silver nitrate. A precipitate is thus. produced on or within certain of the elements in the specimen, giving them a dark-brown or black color. The methods are capricious, and not all of the tisisue-clements of like character in the specimen are rendered prominent. This is an advantage, but necessitates a degree of care in the interpretation of the results. Furthermore, irrelevant precipitates may form in the tissues which have no definite relations to any structure. Considerable practice is, therefore, required for the suceessful employment of all these methods, 
not only for a satisfactory execution of the manipulations, but also in the sturly of the results. The methorls have no value for the study of cell-structure, since the whole cell is either covered or filled with the preeipitates formed during the impregnation with silver.

Golgi has divided his mothods into three groups: the slow, the rapid, and the mixed. For the details of these methods and of the varions molifications introduced by different investigators the student is referred to the jomrnals on microscopy. It must suffice to state liere that the slow method begrins with a hardening of the tissues in a 2 per cent. solution of potassium bichromate, which is gradually raised to 5 per eent. This hardening takes from fifteen days to three months. In the rapid method the tissues are first hardened in a mixture of 4 parts of a 2 per cent. solution of potassium bichromate and 1 part of a 1 per eent. solution of osmic acid. The tissnes remain in this mixture for from two to six days, when they are ready for impregnation. For either method the pieces of tissue should not be thicker than $1.5 \mathrm{~cm}$.

\section{Methods of Dehydration.}

The final manipulation in nearly all the methods for staining described above is a washing of the sections in water. This water must be removed before permanent mounts ean be made. Dehydration is accomplished by treating the sections with alcohol. If they are impregnated, or have been embedded in collodion or celloidin, they must not be dehydrated in absolute alcohol, as that dissolves the collodion. In such eases 95 per eent. alcohol is employed, the sections being treated with two baths of alcohol. When sections have been stained with earmine a contrast-stain may be obtained by adding a few small crystals of picric acid to the first dish of dehydrating alcohol. The excess of picric acid is then removed by the alcohol in the second dish. Absohute alcohol may be used for dehydration when the sections have not been embedded in collodion or celloidin.

When anilin-dyes have been used to stain sections it must be borne in mind that alcohol not merely dehydrates, but also differentiates the stain. If the sections are left too long in the alcohol, they may lose more color than is desired.

Sections that are to be mounted in glycerin or glycerin-jelly require no dehydration, but can be monnted directly from water. 


\section{Methods of Clearing.}

Clearing is necessary when specimens are to be permanently mounted in Canada bilsam or dammar. Its object is to impregmate the section with some liquid that will drive ont alcohol and also be miscible with the resin used for mounting. Of these clearing-agents there is a large number, from which a choice must be made according to the method of embedding that has been employed and the nature of the dye with which the tissues have been stained. Clearing-agents also differ in their miscibility with water, some requiring dehydration with absolute alcohol, others clearing well when 95 per cent. alcohol has been used for dehydration.

1. Xylol.-This is an excellent clearing-agent when the sections have been well dehydrated with absolute aleohol. It does not injure anilin-dyes. It is, perlıaps, the best clearing-agent for sections of tissue stained with borax-carmine before cutting, when no counter-stain is employed. Xylol then both removes the paraffin in the section and clears it.

2. Carbol-xylol. -

$$
\begin{array}{ll}
\text { Carbolic acid crystals (melted), } & 1 \text { vol. } \\
\text { Xylol, } & 3 \text { vols. }
\end{array}
$$

This mixture is much more tolerant of water than pure xylol. Sections dehydrated in 95 per cent. alcohol may be cleared with this reagent, which does not dissolve collodion. The carbolic acid used should be pure, but need not be the more expensive synthetic product.

3. Oil of Bergamot. - This light-green essential oil clears well and does not dissolve collodion. It may be used when 9.5 per cent. alcohol has been employed for dehydrating.

4. Oil of Origanum.-The olenm origani cretici should he used. It is of light-brown color and clears sections dehydrated in 9.5 per cent. alcohol or stronger. It slowly discharges anilin-colors.

5. Oil of Cloves.-This clearing-agent dissolves collodion and discharges anilin-color's. It may be used when it is desired to get rid of the collodion user for embedding after the sections have been stained. This removal is favored by dehydration in absolute alcohol before elearing.

6. Oil of Cedar-wood.-This, when pure, has a very light-yellow color and smells like cedar-wood. It should be free from the more 
pungent odor of the oil derived from the leaves. This essential oil does not diseharge anilin-colors, and is, therefore, useful when those dyes have been employed. It clears slowly, but well, and may be used after dehydration with 95 per cent. alcohol.

\section{Methods of Mounting.}

Sections that have been treated by the foregoing methods of preparation are fitted for mounting in a solution of some resin. "The most commonly employed are Canada balsam and rammar. The best solvent for these resins is $x y l o l$, though chloroform and benzol are sometimes used for this purpose. All traces of turpentine should be removed from the balsam before its solution, to avoid the discharge of stains with hæmatoxylin or anilin-dyes which turpentine occasions.

When sections are transferred from alcohol to a clearing-agent they float upon the surface of the latter, and can then be flattened and all folds removed. As the alcohol is extracted the sections sink in the clearing-agent. In order to transfer them from the clearing-agent to a slicle, the first step in mounting, a good method is to slip a strip of cigarette-paper under the section, withdraw it along with the section (using a platinum needle as aid, if necessary), drain off the superfluous fluid, and then lay the cigarette-paper on the slide, section side down. Light pressure will now squeeze out considerable of the clearing-agent, when the paper can be stripped from the section and slicle, leaving the seetion nearly dry and without folds or wrinkles. With a little care, this method of transferring the section to the slide rarely fails. When such is the ease the manipulations must be repeated.

A drop of the mounting-medium is now placed upon the section and a cover-glass laid on and gently pressed down until it comes in contact with the section and the excess of balsam or dammar is expelled from beneath the cover. If the sections tend to raise the cover, the latter may be weighted with a bullet placed in its centre. Freshly mounted specimens are not so favorable for examination with ligh powers as those that have been mounted for a few hours or days. This is because the refractive indices of the clearing-agent and mounting-medium are not identical. When these have become thoroughly mixed, or the former las evaporated, the specimen is impregnated with and surrounded by a homogeneous nedium that does not scatter the light passing through it. 
Canada balsam has a somewhat higher refractive index than dammar. It therefore renders the sections a little more transparent and more eompletely obliterates the structure-picture. When it is desirel to retain as much of the structure-picture as possible, which is usually the case, dammar should be chosen for the mounting-medium. It dries a little more slowly than balsam, but soon is sufficiently dry at the edges of the cover-glass to preserve the section from injury. If the slides are kept in a horizontal position, in a warm place $\left(40^{\circ}\right.$ to $50^{\circ} \mathrm{C}$; $104^{\circ}$ to $122^{\circ} \mathrm{F}$.), for a couple of days, they will be dry enongh for storage, but for several weeks must be handled with eare.

Stained sections may be examined in grlycerin, having been mounted by the same manipulations as thowe used for mounting in balsam, without previons dehydration or clearing. Such mounts are, however, difficult of preservation. The various eements that have been recommended for fastening the edges of the eover-glass to the slide are usually inefficient, as the changes of temperature that are inevitable canse the glycerin to make its way between the glass and cement, loosening the latter.

A better medium than glycerin for seetions that cannot be subjected to the action of alcohol for the purpose of dehydration is glycerin-jelly. This is prepared by soaking the best French gelatin in cold water until it has imbibed all it will readily take up, then melting the gelatin, after pouring off the excess of water, and anding an equal bulk of glyeerin. A little carbolic acid may be added to the mixture to preserve it. The manipulations for mounting are similar to those given ahove, the sections being transferred from water to the slicle. The glycerin-jelly may be melted and a drop placed upon the section, or a little lump of the solid jelly may be placed upon a cover-glass, melted by gentle heat, and the eovergrlass then inverted over the section on the slide. After the jelly has dried at the edges of the cover-glass they may be painted with xylol balsam, dammar, or some cement.

\section{The Rapid Preparation of Sections for Diagnosis.}

The most expeditions means of obtaining sections of fresh tissues is to ent them without preliminary treatment with reagents, either free hand with a razor, or with the aid of a freezing microtome. Such sections may be stained with methylene-blue, or they may be examined in neutral salt solution. If they are to be stained, 
spread them on a slirle, pour a few drops of the methylene-blue solution over them, and after a few moments wash off" the dye with water and cover the section. If such rapid work is not necestary, the sections can be fixed in formalin (page 287), and, after washing out that reagent, stained. Such sections may be hardened and dehydrated by placing them in dishes of increasingly strong alcohols, and finally mounted in dammar; but the results are by no means so good as when fixation and hardening are done before sections are cut.

When time is not pressing, the following method will give good results :

1. Fix and harden pieces not over $\frac{1}{4}$ inch thick in absolute alcohol kept absolute with anhydrous eupric sulphate. This will take from four to twelve honrs, according to the sizes of the specimens.

2. Dip the specimen in thick collodion and embed it on a glass block by the rapid method. When the block has been in 80 per cent. alcohol for three or four lours it may be cut; but it is better to let the collodion harden for twenty-four hours. If a paraftin microtome is available, remove the alcohol with chloroform, renewed at least once. If the specimens are small, two to four hours will suffice for this step in the proeess. Half an hour each in chloroform saturated with paraffin and in fresh melted paraffin in the oven will accomplish sufficient impregnation with paraffin, and the specimen can then be embedded by the box method.

3. Stain with hæmatoxylin and eosin, cutting short the time of washing after the hematoxylin, if in a hurry.

4. Dehydrate in 95 per cent. alcohol; two snccessive baths.

5. Clear in carbol-xylol.

6. Mount in xylol-rlammar.

When paraffin has been used, follow the directions given on pages 294 and 297.

Very scrviceable sections can be prepared in less than twentyfour hours by these methods, and the specimens, though not of the best quality, will be permanent, and may be kept for future reference. The paraftin method may yield excellent permanent mounts in eight to ten hours if the pieces are small.

\section{Special Methods.}

The foregoing methods are for the preparation of sections of soft tissues. It is sometimes desirable to separate the tissue-elements by some process of maceration, or to prepare sections of calcified tissues, 
snch as bone. Furthermore, some microscopical oljects are obtained suspended in fluids. In these cases special methods of preparation must be used.

1. Examination of Sediments.-For the collection of sediments vessel-c-e. \%., test-tubes-with vertical walls should be used, or a centrifuge may be employed, the sediment being removed from the bottom of the tube with a clean pipette. Place the finger over one end of the pipette before introdueing it into the fluid, to retain the air ; then bring the other end in contact with the sediment and allow the air to escape slowly. Close the upper end of the pipette and withdraw it. Carefully wipe the outside of the pipette, and transfer the sediment to a slide and eover it with a eover-glass. Many sediments may be stained with alum-carmine, methylene-blue, or Gram's solution, drained, and mounted in glycerin jelly.

2. Microchemical Reactions.-These reactions are resorted to to determine the chemical nature of objects under the microscope. Every stain is the result of a microchemical reaction, but as yet the knowledge obtained by staining tissues cannot always be expressed in chenical langnage.

The manipulations are usually so conducted that the reaction can. be direetly observed under the mieroscope. The object to be studied. is placed in the middle of the field. The reagent used is then placed at one adge of the cover-glass, whence some of it will flow beneath the latter. To facilitate the entrance of the reagent a narrow strip of filter-paper may be brought in eontact with the opposite edge of the cover, withdrawing some of the fluid from beneath it. It is best to sharpen the end of the strip which comes in contact with the cover-glass, so that the absorption of fiuid shall be slow; otherwise the currents indueed will be likely to wash the object from the field of vision. The following tests, applied in this. way, may be of use:

a. Urates. Insoluble in 1 per cent. acetic acid; soluble, on the application of heat, in water (or urine). The slide must be removed: from the microscope when heat is applied to it.

b. Fartly phosphates. Dissolve on the addition of 1 per cent. acetic acid. Are not disosolved by heat.

c. Calcium oxalate. Insoluble in 1 per eent. acetic acid; soluble in 1 per cent. hydrochloric aeid.

d. Carbonates. Soluble in 1 per cent. acetie acid or hydrochlorie acid, with evolution of gas-bubbles. 
e. Albuminoid granules. Become indistinct, and finally invisible, on the addition of 1 per eent. acetic acid or 1 per cent. potassium hydrate; not blackened by osmic acid.

f. Fatty granules. Not affected by 1 per cent. acetic acisl or 1 per cent. potassium hydrate. Stained black or dark brown by osmie acil.

\%. Starch. Stained dark blue to black by iodine solutions. Use Gram's solution.

h. Cellulose. Stained yellow by iodine solutions. If the water be then removed and concentrated sulphuric acid introdnced, the color becomes blue. The walls of most regetable cells are composed of cellulose.

i. Teichmann's test for hrmoglobin. This test depends upon the conversion of the hæmoglobin or its derivatives into hæmin, which crystallizes in rhombic plates of a reddish-brown color. 'The hamin is produced by heating with a little salt and strong acetic acid. Evaporate a drop of neutral salt solution to dryness on a slide. Place the substance to be tested upon it and cover. Fill the space between cover and slide with glacial acetic acid and heat over a Hame till bubbles begin to form. Maintain that heat for a few minutes, replacing loss by fresh additions of acetic acid. Let the slide cool slowly, and, when cold, exanine. If the results are negative, repeat the heating with acetic acid. The acid should not actually boil, but should be kept at the point of incipient ebullition.

$j$. Tests for amyloid substanee. Sections of fresh tissue may be soaked for some time in Gram's solution, then washed and examined in water. Anyloid substance is stained reddish-brown, the tissues yellow. Scetions of tissues fixed in aleohol, corrosive sublimate, or formaldehyde, may be stained in a solution of 1 per eent. methylviolet dissolved in distilled water, withont the addition of alcohol. The sections are then washed in 1 per cent. hydrochloric acid for the purpose of differentiating the stain. After thorough washing in several changes of water they may be mounted in glycerin-jelly. The amyloid substance is stained reddish-violet, the other tissues blue.

$k$. Test for iron in pigmentations. The iron from the hamoglobin of the blood is sometimes present in the pigmentation resulting from old extravasations, in the form of hæmosiderin. The same componnd is also sometimes found in the tissues in cases of 
pernicious anæmia. The presence of iron in this pigmentation may be demonstrated by the following method:

(a) The tissues should be fixed in alcohol.

(b) Soak the section in a 2 per cent. solution of potassium ferrocyanide for ten minutes.

(a) Transfer to Orth's acid alcohol (page 290) for five or ten minutes.

The seetions may now be examined in a glyeerin-mount with a wide diaphragm, or they may be connterstained, for which purpose treat as follows:

(d) Wash with water.

(e) Stain with Orth's lithio-earmine.

(f) Dehydrate and mount in xylol-dammar.

The iron in the section is converted into Prussian blue; the nuclei of the cells, when the counterstain has been employed, are red.

1. Examination of sputa for elastic fibres. In pulmonary disease involving a destruction of pulmonary tissue and the appearance of fragments in the expectoration, elastic fibres from the alveolar walls may frequently be found in the sputa:

Fill a test-tube one-third full of sputa, add five or six drops of 36 per cent. potassium hydrate solution, and boil the mixture for three or four minutes. Add an equal bulk of distilled water. Divide the eontents of the tube between the two tubes of the centrifuge and precipitate their contents. If elastie fibres were present, they will be found either in the sediment or in the seum on the top of the fluid.

\section{Methods of Maceration.-}

a. One-third aleohol.

95 per cent. alcohol,

Distilled water,

$35 \mathrm{ce}$.

65 “

This dilute aleohol is excellent for the separation of epithelium from the surfices of mucous membrames. The fresh tissues are placed in the alcohol for a day or two, after which the cells can easily be detached and separated by shaking. The cells are well preserved, and may be stained with methylene-blue or alum-earmine.

b. Potassium hydrate.

Potassium hydrate, pure by alcohol, Distilled water,

36 grams.

$64 \mathrm{ce}$. 
The solution should be cold before use. It cannot be filtered through paper ; but if not elear, should be decanted from any sediment, or a fresh solution prepared. Maceration takes place very quickly in this solution. The tissues can usually be teased apart within fifteen to thirty minutes. They must be examined in the potash solution without dilution, as the addition of water quickly destroys the tissue-elements. For this reason the specimens to be macerated should be placed in several times their bulk of the potash solution; otherwise the water they contain will dilute the potash. Permanent mounts cannot be made.

c. Chromic acid. A solution of 1 part of the acid in 10,000 parts of distilled water will fileilitate the teasing apart of tissueelements which have macerated in it for one to several days. After careful washing on the slide alum-carmine alone, or followed by picric acid, may be used for staining.

4. Methods of Decalcification.-Tissues which contain caleified nodules or bone must be freed from lime-salts before they can be ent. It is difficult to do this rapidly without injury to the softer tissue-elements. When good results are desired, and the necessary time can be afforded, the tissues should first be fixed and hardened, small pieces being selected. 'Zenker's fluid fixes well for this purpose, but Orth's fluid or alcohol may be used. If Zenker's or Orth's fluid is used, the tissues must be washed in water and hardened in aleohol for at least a day before they are decaleitied.

Decalcification is aecomplished by treatment with acids. Five per cent. nitric acid will decalcify small picees of bone in from one to five days. The progress of the decalcification may be determined by pricking the tissue with a needle, but after it appears to be soft it is well to continue the action of the acid for a day or two, lest some undissolved particles should remain and injure the edge of the microtome-kuife. A saturated aqueous solution of picric acid is sometimes used for decalcifying. Its action is very slow, though not injurions to the tissues, which require no preliminary treatment, the pierie acid acting as a fixing and decaleifying agent.

After decalcifying in nitric acid the tissues should be thoroughly washed in running water for twenty-four hours and then rehardened in alcohol, after which they may be embedded. After decaleifying in picric acid the tissues are placed in 70 per cent. alcohol and hardened without previous washing in water. 
When rapid decalcification is necessary nitric aeid and phloroglucin, which restrains the destructive action of the acid, may he used. The solution is prepared by dissolving 1 gram of phlorogluein in $10 \mathrm{ee}$ of pure nitrie acid. To this $100 \mathrm{ec}$ of 10 per eent. nitric acil are added. Decalcification takes place within a few hours in this solution, whieh contains abont 20 ner cent. of nitric acid. The tissues should then be washed and hardened.

Another rapid method which combines decaleifieation with hardening is to place the fresh tissues in a large bulk of 5 per cent. nitrie acid in 80 per cent. alcohol. After decalcifieation has taken place the tissues are hardened in alcohols of increasing strength, large quantities being used in orter to remove the acid. Before staining, the section: shonld be washed thoronghly in water to get rid of any residual traces of aeid. 


\section{INDEX.}

$\triangle$ BBE condenser, 281

A Absorption, 128

Achromatic spindle, 38

Achromatin, 35

Acidophilic cells. 125

lencocytes, 125

Acini, glandular, 62,63

A cromegaly, 199

Adipose tissue, 83 functions of , st

Adrenal borlies, 188, 194 zona granulusa of, 195 reticularis of, 195

Adventitia, 116, 118

Afferent vessels of kidney, 165 of lympli-glands, 122

Air pastages, 176

Albumin, egg, Mayer's, 302

Albuminoid granules, tests for, 319

Albuminuria, 170,191

Alcohol, absolute, 289 methods of maceration, 320

Alum-carmine, 306

methods of staining, 306

Alveolar vassages, 178

Alveoli, glandular, 62 pulmonary, 179

Amacrinas, cellulas, 249 (Fig. 232)

Amoba, 28

comparison with other cells, 30

Amoboid movement, 29

Ampulla of breast, 232

Amylacea, corpora, 238

Amyloid, 319

Anabolism, 31

Anilin-water, 309

Animals, multicellular, 28

unicellular, 27,28

Aponeuroses, 85

Arcales, vascular, of kidney, 165

Areolar tissue, 80 development of, 80

"ground-substance" of, 80

Arrectores pili, 211

Arterial arcade of kidney, 165

Arteries, 116

helicine, $2: 7$

Artery, hepatic, 154, 156
Articular cartilages, 70

Arytenoid cartilage, 178

Assinilation, nucleas in, 33

Association-cells, see Spongioblasts, 249, 277

Association-fibres of cerebrum, 263 of spinal cord, 253

Attraction-spheres, 36

Axis-cylinder, 100, 103, 248

BAND, constricting, of Ranvier, $10 t$

B Basement-membrane, 60, 140, 147,246

Basophilic leucocytes, 126, 133

Bergamot, oil of, 314 inethods of clearing, 314

Bile capillaries, 157,158 duet, 154,160

Bioplasm, see Cytoplasm, 29, 32

Bipolar nerve-cells, 101

Bladder, 172

lining of, 172

Blood, 128

functions of, 114,130

Blood-plates, 128, 133

Bodies, adrenal, 194

carotid, 189, 202

Malpighian, of kidney, 162 of spleen, 18.5

Pacinian, 266 polar, 36, 231

Body, coccygeal, 189, 203 pituitary, 197

Bone, 70

canaliculi of, 70

cement in, 72

clasification of, 72

corpuscles, 70

decalcifierl, 71

development of, 73

effects of decalcification on, 71

general character of, 70

"ground substance" of, 72

Haversian canals of, 70

intercellular substances in, 72

lacunce of, 70

nutrition of 73

Bone-marrow, 73,125 
Bone-marrow, red, 125 yellow, 125, 127

Borax-carmine, 307 methods of staining, 307

Boundary zone of kidney, 161

Bowman, glands of, 269

Bowman's capsule, 169

Breast, see Lammary gland, 232 ampulla of, 232

Bridges, intercellular, 58, 88,89

Bronchi, 177

Bronchial cartilages, 178

Bronchioles, $17 \mathrm{~S}$

Brownian movement, 29

Brumner, glands of , 148, 149

Bulb, olfactory, 272 glomeruli of, 272

CACHEXIA strumipriva, 191

$\cup$ Calcium oxalate, tests for, 318

Callus, 57

Canada-balsam, 315,316 methods of mounting, 315,316

Canal, central, 22 neural, 22,23

Canaliculi of bone, 70

Canals, Haversian, 72,73

Cancellated bone, 70

Capillaries, 47, 50, 119 bile, 157,158

Cansule, Bowman's, 167

Glisson's, 124. 155

of kidney, 170

of spleen, 134

Capsules, suprarenal, 194

Carbohydrates, in cytoplasm, 32

Carbol-fuchsin, 309 methods of staining, 309

Carbol-xylol, 314 methods of clearing, 314

Carbon in lymph-nodes, 125

Carbonates, tests for, 318

Cardiac glands, 144 muscles, 94

Carmine, alum-, 306 methods of staining, 306 borax,- 307 methods of staining, 307 lithio-, 307 methods of staining, 307 neutral, 306

methods of staining, 306

Carotid bodies, 189, 202 glands, 202

Cartilage, 6i; articilar, 68 classification of, 67 costal, 68 cricoid, 176
Cartilage, elastic, 69

ensiform, 66

of Eustachian tube, 69

fibro-, 68

functions of, 70

general character of, 66

in heart, $6 \mathrm{~s}$

hyaline, 68

interarticular, 68

intercellular substance in, 67

matrix of, 67

nutrition of, $6 \mathrm{~s}$

ossification of, 66,74

temporary, 68

thyroid, 176

Cartilages, arytenoid, 176

bronchial, 178

tracheal, 177

Catabolism, 32

Cavities, serous, 47

Cedar-wood, oil of, 280, 314 methods of clearing, 314

Cell. or cells, 27 acidophilic, 127 of connective tissue, 76,81 constituents of, structural, 31 death of, 42 decidual, 225

of Deiters, 274

differentiation of, 27

-division, 35,40

amitotic, 40

centrosome in, 35

direct, 35,40

indirect, 35

ectoplasm of, 29, 30

endothelial, 47

epithelial. 51

of fibrous tissue, 76

fixed, 30

functions of, 32

gauglion-, 100,248

giant-, 42,127

glia-, 107

goblet-, 54, 139

hair-, 207,274

lutein, 219

membrane, 30

migratory, 128

mitral, $2 \div 2$

nodification of, related to function, 27

of Hiiller, 275

muscular, $87,94,96$

nerve-, 100

bipolar, 100

multipolar, 100

unipolar, 100

organization of, 32 
Cell or cells, orrans of, 31,32 plasma-, 126

polar bodies of, 36

poles of, 34

prickle-, 57,205

primitive, 27,31

of P'urkinje, 257

pyriform, 58

reprorluction of, 35,40

of Sertoli, 242

simplest, 28

specialization of, 27

splenic, 186

stellate, 259

large, 259

small, 259

structure of, 27,31

sustentacular, of retina, 276 of testis, 245

unspecialized, 27

wandering, 132

Celloidin, see Collodion, 292, 295

Cellulas amacrinas, 249 (Fig. 232)

Cellulose, tests for, 319

Cement of teeth, 213, 214

substance, 47

in bone, 78

in fibrous tissue, 80

in muscular tissue, 92

Central nervous system, 111

veins, 156

Centrosome, $31,34,35$

division of, 34,39

function of, 33

Cerebellum, 257

Cerebrum, 260

association-fibres of, 264

commissure-fibres of, 263

projection-fibres of, 263

Cheek, lining of 56

Chemotaxis, 29

Chemotropism, 29

Chromatin, 34

reduction of, 240,245

Chromic acirl, 321 methods of maceration, 320

Chromolysis, 234

Chromophilic granules of nerve-cells, 102

Chromoplasm, 34,40

and heredity, 40

during karyokinesis, 35

Chromosomes, 37 (Fig. 8), 39

Chyle, 134

Cilia, 27, 55

movement of, 27

Ciliated epithelium, 44, 55

Circulation, intracellular, 30

Circulatory system, 114
Clarke, columns of, 253,255

Classification of bone, 72

of bone-marrow, 73,125

of cartilage, 67

of connective tissues, 65

of epithelium, 51, et seq

of fibrous tissue, 74,76

of glands, 60 , et seq.

of muscular tissues, 87

of nerve-cells, 102.248

of nerve-tibres, 102

Cleaning objectives, 279

Clearing, methorls of, 314

bergamot, oil of, 314

carbol-xylol, 314

cedar-wood, oil of, 314

cloves, oil of, 314

origanum, oil of, 314

xylol, 314

Clefts of Lanterman, 105

Cloves, oil of, 314 methods of clearing, 314

Coagulation, explanation of, 134

Coceygeal body, 189, 203 gland, 203

Collateral fibres of spinal cord, 253

Collecting tubules of kidney, 103, 168

Collodion, 292, 295

embedding, 295

methods of impregnation, 292

Colloid degeneration in thyroid, 189 in hypophysis, 197 in thyroid body, 189

Colon, 149

Colostrum, 233 -corpuscles, 293

Columnar epithelium, 54

Columns of Clarke, 253,255

Commissure-fibres of cerebrum, 263

Condenser, Abbe, 280

Connective tissue, 65

cells of, 76,81

classification of, 65,74

development of, 65,77

fibres, staining of, 310

functions of, $65,79,81$

intercellular substance in, 65

Contractile substance, 87

vacuoles, 30

Convoluted tubules of kidney, 163

Cord, spinal, 250

nmbilical, 79

vocal, 176

Corium, 204

Cornicula of larynx, 69, 176

Corpora amylacea, $2+4$ cavernosa, 242

Corpus album, 220

cavernosum, 242 
Corpus, hæmorrhagicum, 220

luteum, 2.211

spongiosum, 242

Corpuscles, colostrum-, 233

genital, 267

of Hassall, 200

of Kranse, 267

Malpighian, of spleen, 186

of Meissner, 267

red, 130

diameter of, 281

nucleated, 125, 130

stroma of', 130

tactile, 266

white, 131

Cortex of kidney, 161

of lymph-glands, 121

Costal cartilages, 68

Crescents of Gianuzzi, 139

Cricoid cartilage, 176

Crypts of Lieberkialın, 147 of stomach, 142

Cubical epithelium, 51

Cuticle of epithelium, 52 of hair, 209

Cuticularized epithelium, 56

Cutting, methods of, 299

celloidin sections, 301

eollodion sections, 301

free-hand, 299

frozen sections, 300

paraffine sections, 301

C5toplasm, 29, 32, 33

carbohydrates in, 32

division of, in cell reproduction, 38

fats in, 32

functions of, 32

proteids in, 32

salts in, 32

water in, 32

D AMMAR, methorls of mounting, 315

Danghter nucleus, 38

Decalcification, effects of, on bone, 71 methods of, 321

Decidua, 225

Decidual cells, 225

Degeneration, keratoid, 211

Dehydration, methods of, 313

Deiter's' cells, 274

Dendrite, 248

Dendritic processes, 101, 248

Dentin, 213, 214

Dentopla:m, 2?

Derelopment:

of areolar tissue, 81

of bone, 73

of connective tisiue, 65,78
Development of endothelium, 51 of epithelium, 64 of fibrous tissue, is of glands, 63

Diaphragm iris, 280 of microscope, use of, 280

Diaster-pha-e of karyokinesis, 39

Differentiation in structure, 28

Diffusion, 129

Digestion, intracellnlar, 30

Digestive function, 30 organs, 136

Direct celi division, 35, 40

Discus proligerus, 217

Disks, intervertebral, 68

Dispirem-phase of karyokinesis, 39

Duct, bile-, 154,160

thoracic, $12 \cdot 2$

Ductless glands, 64,188

Ducts of glands, 61

Duodenum, 145

WAR, 69, 273

L) Ectoderm, 20

Eetoplasm, 29

Efferent vessels of the kidney, 166 of lymph-glands, 122

Egg, 20,231

albumin, 302

Elastic cartilage, 69

fibres, $76,77,320$

Elastin, 78

Eleidin, 206

Elementary tissues, 43 recognition of, 45

structural variations $i n, 45$

Elements, sarcous, 98

Elimination, 44

Embedding, methods of, $29 \pm$ celloidin, 29.5 collodion, 295 paraftin, 297 tissues, 283

Embryonie layers, 22

Enamel of teeth, 213, 214

Endoeardium, 116

Endoderm, 24)

Endomysium, 98

Endoneurim, 106

Endoplasm, 2!

Endothelial cells, t7

Endothelinm, 4i

development of, 51

functions of, 50

general characters of, 47

intercellular substance in, $4 \bar{\imath}, 49$

Energy, kinetic, 18

potential, 18

Ensiform eartilage, 66 


\section{Enzymes, 32}

\section{Eosin, 30.5}

methods of staining, 305

Eusinophilic leucocytes, 12.5

Ependyma, 109

Epicardium, 115

Epidermis, 57, 204, 205

Epididymis, 239

Epiglottis, 69, 176

Epimysium, 98

Epineurium, 106

Epithelial cells, 51 pyriform, 58 tissues, 47

Epithelium, 43, 51

activities of, 59

ciliated, 55

classifieation of, 51 , et seq.

columnar, 54

cubical, 51

cuticle of, 52

cuticularizerl, 56

development of, ift

excretory, 44,52

functions of, 43,59

general characters of, 51

germinal, 215

glandular, 44,52

horny, 43,56

intercellular substance in, 51

mucigenous, $4 t$

pavement-, 53

secretory, 44

stratified, 56

transitional, 58

Erectile tissue, 2315

Eryth roblasts, 12.5, 130

Erythrocytes, see Red corpuscles, 130

Eustachian tube, cartilage of, 69

Excretion, 44

External genitals, 230, 236

Eye, 275

vitreous liumor of, 79

1.1 LLOPIAN tubes, 220

Fat, 8 ?

Fascia, 70,82

infiltration with, 82

Fats in cytoplasm, 32

Fatty degeneration, 209, 230 granules, tests for, 319

Female organs of generation, 215

Fenestrated membrane of Henle, 77, 117

Ferments, 32, 4.5

Fibres, association-, of cerebrum, 264 in bone, 72

collateral, of cord, 253

commissure-, of cerebrum, 263
Fibres, connective-tissue, staining, 310 of cord, 253

elastic, 77

moss-, 246

nerve-, 102

classification of 102

-staining, 311

non-elastic, 76

non-medullated, 10:2

projection-, of cerebrum, 263

Sharpey's, 72

Weismann's, 99

white, 76

yellow, 77

Fibrin, 134

formation, 134

Fibroblasts, 79

Fibro-cartilage, 68

Fibrous tissues, 76

cells of, 76

cement in, 76

classification of, 76,78

development of, 77

general character of, 76

ground-substance of, 76

Figures, mitotic, preservation of, $2 \$ 8$

Filtration in lymph formation, 129

Fixation of tissues, 283, 290

methods of, 285

alcohol, absolute, 289

boiling, 290

Flemming's solution, 288

formaldelivde, 287

mereuric chloride solution, 287

Müller's fluid, 285

Orth's fluid, 286

Zenker's fluid, 286

Flemming's solution, 288

Follicles, Graafian, 215

hair-, 207

lymph-, 80, 148, 151

Formaldehyde, 287

Foveole, Howship's, 75

Freezing-point, depression of, 129

Fresh specimens, examination of, 286 , 299

Frozen sections, 300

Fuchsin, carbol-, methods of staining, 309

Function and structure, $27,28,32,43$, $59,(2,2,65,70,83,84$

Function, or functions,

of adipose tissue, 84

of blood, 111, 130

of cardiac muscle, 96

of cartilage, 70

of centrosome, 32

of connective-tissue, 65, 84

of eytoplasm, 32 
Function or functions, digestive, 30 of endothelium, 50

of epithelium, 43, $62,53-55,57,59$ of hypophysis, 197

of liver, 159

of lung, 181

of lymph, 114

of lymph-nodes, 125

of nervous tissue, 87

of nuclei, 32

nutritive, of cells, 65

perceptive, 30

of smooth muscles, 93

of spleen, 186

of thyroid body, 189, 191

Funiculi of nerves, 106

ALACTIFEROUS ducts, 232

G Gall-bladder, 160

Gall-duct, 157, 150

Gelvanotropism, 30

Ganglia, 105

of heart, 118

Ganglion-cells, 100, 248

Generation, female organs of, 215 male organs of, 236

Genital corpuscles, 267

Genitals, external, 230

Gentian violet, 309 methods of staining, 309

Geotropism, 30

Germinal epithelium, 215

$$
\text { of ovary, } 215
$$

Giant cells, 42, 125

Gianuzzi, crescents of, 139

Gland, mannary, 232

thymus, 188,200

thyroid, 189

Glands, 44, 52, 55, 60

of Bowman, 269

of Brunner, 148

cardiac, of stomach, 144

carotid, 202

classification of, 61

coccygeal, 203

compound, 61

development of, 63

ductles, $6 \cdot 4,188$

ducts of, 61

lymphatic, 122

mammary, 232

parotid, i3?

pyloric, of stomach, 142

racemose, 61,232

saccular, 61

salivary, 139

sebaceous, 209

secreting, 60,232

simple, 61
Crlands, sublingual, 139

submaxillary, 139

sweat-, 206

thyroid, 188, 189

tubular, 61

of Tyson, 237

Glandular alveoli, 62 epithelium, 52

Glans penis, 236,237

Glia-cells, 107

Glisson's capsule, 154,155

Glomeruli of kidney, 166 olfactory, 272

Gilomerulus, 166

Glucose, 45, 159

(ilycerin, 316 jelly, 316

Glycogen, 45, 52, 158, 160

methods of mounting, 316

Goblet-cells, 54, 147

Golgi's method of staining, 312

"Goose-Hlesh," 211

Graafian follicles, 215 development of, 217

Gram's solution, 310

Granules, chromophilic, of nerve-cells, 102

Gray matter, of spinal cord, 250 nerve-fibres, 106

"Ground-substance": of areolar tissue, 78 of bone, 72

of central nervous system, 108

of fibrous tissue, 76

of mucous tissue, $7 \mathrm{~S}$

of reticular tissue, 80

U EMATOX YLIN, 304

1 methods of staining with, 304

Hæmoglobin, 130, 131

tests for, 319

Hair, 207

color of, 209

cortex of, 209

cuticle of, 209

Hair-cells, 274

Hair-follicles, 207, 213

development of, 212

medulla of, 209

Hardening, methods of, 291

Hassall, corpuscles of, 200

Haversian canals, $70,73,74$ system, 73

Hearinur, 273

Heart, 115

cartilage in, 68,116

valves of, 116

Heat-regulation, 212

Helicine arteries, 237 
Heliotropism, 29

Iron, tests for, 319

Henle, fenestrated membrane of, 77, Islands of Langerhans, 151 117 loop of, 163 tubes of, 163

Hepatic artery, 154, 156 vein, 154,156

Hereclity, nuclear function in, 32,231 , 232,240

Horny epithelium, 44

Howship's foveolre, 75

Hyaline cartilage, 68

Hyaloplasm, 29, 33

Hydrotropism, 30

Hymen, 230

Hypophysis cerebri, 197

TLLUMINATION, microscopical, I 281

Image, microscopical, 280, 284

Immersion-objectives, 280

Impregnation, methods of, 292 celloidin, 292 collodion, 292 paraffin, 292

Indirect cell-division, 35

Infiltration with fat, 82

Infundibula of lung, 179

Infusion, 27

Interalverolar cell-islets, 151

Interarticular cartilages, 68

Intercellular bridges, 58,88 substances, 24, 44 in bone, 72

in cartilage, 67

in connective-tissue, 65

in endothelium, 47, 49

in epithelium, 51

in muscle, $86,88,94$

Interlobular vessels of kidney, 165 of liver, 1.55

Internal secretion, 44, 64, 151

Interpretation of microscopical appearances, $89,183,278,281$

Interstitial tissue, 80

Interstitium, 112

Intervertebral disks, 68

Intestine, large, 149

lining cells of, 56

muscularis mucose of, 147 small, 145,149 villi of, 146,147

Intima, 116

Intracellular circulation, 30 digestion, 30

Involuntary muscles, 87

Iodothyrin, see Thyroidin, 192

Iris, liaphragm, 280

Iron, hematoxylin stain, 311

T ARYOKINESIS, 3i;

chromoplasm during, 36

diaster-phase, 39

dispirem-phase, 39

monaster-phase, 37

significance of, 39

spirem-phase, 36

Karyolysis, 220

Karyoplasm, 34

Keratin, 56, 206

Keratoid degeneration, 208

Kidney, afferent vessels of, 165 boundary zone of, 161 capsule of, 170

collecting tubules of, 163,168

cortex of, 161

efferent vessels of, 166

interlobular vessels of, 165

labyrinth of, 163

lobes of, 161

Malpighian bodies of, 162

medulla of, 161

papillæ of, $161,162,168$

pelvis of, 171

stellate veins of, 147

vascular arcades of, 165

Kidneys, 161

Kinetic energy, 18

Krause, corpuscles of, 267

IBYRINTH of kidney, 163

4 Lacteals, 120

Lacuna of bone, 70

Langerhans, islands of, 151

Lanterman, elefts of, 105

Lanthanin, $3 \overline{5}$

Larynx, 176

Layers, embryonic, 22

Lenses, cleaning, 279

Leucocytes, 126, 128, 131

acidophilic, 125, 133

basophilic, 126,183

eosinophilic, 125, 133

large mononuclear, 125, 133

polynuclear neutrophilic, 132

Lieberkiihn, crypts of, 147

Ligaments, 82, 84

Ligamentuin nuchæ, 85

Linin, 3.5

Liquor folliculi, 217

Lithio-carmine, 307

methods of staining, 307

Littré's glands, 174

Liver, 154

functions of, 159

interlobular vessels of, 155 
Liver, intralobular vessels of, 156 lobules of, 15.5

Lohes of killuey, 161

Lohmles of kidiey, 162 of liver, 155 of lumg, 180

Lumg, circulation of, 181 fortal 53 functions of, 181 infundibula of, 179 Iobules of, 180 structure of 177,183

Lymph, 120, 129, 134 circulation of, 115 -follicles, 81), 121, 139, 148, 151, 185 functions of, 114 formation of, 129 -glands, 120

aflerent vessels of 122 cortex of, 121

efferent vessels of, 122 medulla of, 121

-nodes, 120

carbon in, 125

fiunction of, 125

-sinus, 122

trabecula of', 121

spaces, 48, 81, 114, 120, 156

Lymphadenoid tissue, 78

Lymphatic glands, 78,120 valves, 115,120 vessels, 120

Lympliocytes, 133

II

ACERATION, methods of, 320 alcohol, 320

chromic acid, 321 potassinm hydrate, 320

Malaria, 184

Male organs of generation, 236

Malpighian bodies of kiduey, 161, 162 of spleen, 186

Mammary gland, 232

Marrow, 74,125

mucoisl, 125

red, 125

vellow, 125, 127

Matrix of cartilage, 67

Maturation of the ovum, 231

Mayer's albumin, 302

Measurements, microscopical, 280

Merlia, 116, 118, 119

Medulla of bone, see Marrow, 125 of kiduev, 161 of lymph-glands, 121

Medullary rays, 161 sheath, 103

Medullated nerve-fil,res, 102

Meissner, corpuscles of, 267
Membrane, basement, 60, 140, 147, 246 fenestrated, 77, 117

Membranes, mucous, 55, 60

Menstruation, 223

Mercuric chloride solution, 287

Mesentery, 48

Mesoderm, 22

Metakinesis, 37

Metaplasm, 33,52

Metazoa, 28, 112

Methylene-blue, aqueous, 308 methods of staining, 308 Unma's 308

Nicrochemical reactions, 318

Micrometer, 280, 281 scales, 280

Micromillimeter, see Micrometer, 280

Iicroscope, care of, 279 selection of, 279

Microscopical appearances, interpre. tation of. $89,183,278,285$

measurements, 280

technique, 279

Migratory celís, 132

Milk, $23 \dot{4}$

Mitral cells, 272

Mitosis, see Karyokinesis, 35

Iolecular concentration, 129

IIonaster-phase of karyokinesis, 37

Hononuclear lencocytes, large, 133

Moss-fibres, 260

Motor plates, 110

Mounting, methods of 315 Canada-balsam, 315,316 dammar, 315,316 glycerin, 316 glycerin-jelly, 316

Mouth, lining of, 57

Iorement, ammboid, 29

Brownian, 29

of cilia, 27

Mucin, is

Mucoid marrow, 125

Mucosum, rete, 205

IIucous membranes, 55, 60 covering of, 55

ti-slle, 78

"ground-substance" of, 78

Müller, cells of, 275

fluid of, 285

Multicellular animals, 28,112

Multipolar nerve-cells, 100

Muscle, cardiac, it

intereellular substance in, 86

involuntary, 87

nutrition of, 88

smooth, 87

function of, 93

-spindle, 99 
Muscle, striated, 96 unstriped, 89

voluntary, $9 k$

Museular cells, $86,87,94,96$

sense, 99

tisisues, 87 cenent in, 88

Muscularis muensie of intestine, 147 of cesophagus, 142

of stomach, 142, 14j

of uterus, $2 \cdot 2 \cdot 2$

Myelin, 108, 104

Mrelocytes, 125

Myxoedema, 191

NAILS, 211

Nerve-cells, 101

bipolar, 101

chromophilic granules of, 102 multipolar, 101

protoplasmie processes of, 103

Nerve-fibres, 102 unipolar, 101

classification of 102

gray, 102,106

uon-medullated, 102, 106

Nerve-terminations, 109

Nerves, 106

funiculi of, 106

Nervous srstem, 248 central, ground-substance of, 110 tissue: 100

functions of, 87

Neurilemma, 108, 104

Neurite, 248

Neuroglia, 107

Neurokeratin, 105

Neurons, 248

Neutral earmine, 306

Nipple, 242

Nodes, Jymph-, 120 of Panvier, 104

Non-elastic fibres, 76

Non-medullated nerve-fibres, 102, 106

Normal salt solution, see Neutral solution, 281

Nose, lining of, 55,269

Nucleated red corpuseles, 119, 123

Nuclei, functions of, 33

Nucleolus, 29, 34

Nucleus, 29, 31, 33

multiple division of, 39

structure of, 34,39

during cell division, 35,40

Nutrition :

of bone, 73

of cartilage, 68

of nuscle, 84

of tissues, 81, 82, 114, 117
B.JECTIVES, 279

inmersion, 279, 280

Ocular mierometer, 280

Oculars, 279

Odontoblast., 214

(Eilematin, 35

Esophagrus, 142

lining of it

muscularis mucose of 142

"tunica propria" of, 142

Olfactory bulb, 272 lavers of, 272

glomeruli, 272

Oil of bergamnt, 314

of cedar-wood, 280,314

of cloves, 314

of origanum, 314

Organ:, 112

of generation, female, 215 male, 236

Origanum, oil of, 314 method of cleaning, 314

Orth's fluid, 286

Osmosis, 117,129

1):sification of eartilage, 66,72

Osteoblast-i, $7 \pm$

Osteoclasts, 75,126

Ovary, 215

germinal epithelium of, 215

stroma of, 215

Ovula Nabothi, 229

Ovum, 20, 215, 217

maturation of, 231

maturing, polar hodies of, 231

DACINIAN bodies, $26 \%$

Pal's method of staining, 311

Pancreas, 150

Papilla of kidney, 161, 162, 168

of skin. 205

of tongue, 138

Paraffin, 282, 293, 297

embediling, 297

methods of impregnation, 292

Parathyroids, 193

Parenchrma, 112

Parotid gland, 139

Parovarium, 231

Passages, alveolar, 178

respiratory, 53, 176

Pavement-epithelium, 53

Pelvis of kilney, 171

renal, 171

lining of, 58

Penis, 236

trabecula of, 236

Perceptive function, $3 C$

Pericardimm, 115 
Perichondritum, 67

Perinysium, 98

Perineurium, 106

Periosteum, 74

Peristalsis, 88, 136

Peritonemm, 137

Perspiration, "211

Peyer's patches, 149

l'hagocytes, 124, 125, 132

Phosphates, earthy, tests for, 318

Pia mater, 109

Picture, color-, 284

structure, 284

Pituitary body, 197

Placenta, 2206

Plasma, 114, 129

Plasma-cells, 126

Plates, blood-, 127

Polar bodies of dividing cell, 36 of maturing ovum, 231

Polynuclear neutrophilic leucocytes, 133

Portal vein, 154, 159

Potassium hydrate, $2 \$ 1,320$

I'otential energy, is

Pregnancy, 224

Prickle-cells, 57, 205

Primitive cells, 27,31 sheath, 104

Processes, axis-cylinder, 100 dendritic, 101

protoplasmic, 100

Projection-fibres of cerebrum, 263

Prostate, 238

Proteids in cytoplasm, 32

Protoplasm, 29

movements in, 29

Protoplasmic processes of nerve-cells, 103

Protozoa, 28, 112

Pseudopodium, 29

Pseudo-stomata, 49

Pulmonary alveoli, 179 lining of, 53

Pulp of spleen, 184 of teetls, 213,214

Purkinje, cells of. 257

Pylorie glands, 142

D ACEMOSE glands, 61, 137

R lanvier, constricting bands of, 104

norles of, 104

Rays, medullary, 161

Razor, stropping, 299

Reactions, microchemical, 318

Rectum, 150)

lining of $5 \%$

Red corpuscles, 130
Red corpuscles, nucleated, 125

stroma of, 130

Red marrow of bone, 125

Reduction of chromatin, 240,245

Renal pelvis, 171

lining of, 58

tubules, 161, et seq.

Reproduction, 20,30

Reproductive organs, 215

Respiration, 30, 53, 55, 132, 176, 178

Respiratory organs, 176 passages, 53,55

Rete mucosum, 250 vasculosum, 247

Reticular tissue, 79,85 "ground substance" of, 80

Retina, 275 sustentacular cells of, 275

Rugæe of stomach, 145

dACCULAR glands, 61

S Salivary glands, 139

Salt solution, normal, 281

Salts in eytoplasm, 32

Sarcolemma, 98

Sareoplasm, 98

Sarcostyles, 96,98

sarcous elenents, 98

Seales, micrometer, 280

Schwann, sheath of, 104 white substance of, 103

Sebaceous glands, 209

Sebum, 209

Secreting glands, 44, 60

Secretion, 44, 45, 60 internal, 44, 6it, 191, 207

Secretory epithelium, 4

Sections of tissues, 282 interpretation of $89,183,278,281$ rapid preparation of, 316 staining of, 303

Sediments, examination of, 318

Seminal vesicles, 239

Seminiferous tubules, 240, 241

Serous carities, 47,48 stomata in, 154 membranes, 50

Sertoli, cells of, 242

Sharpey's fibres, 72

Sheath, medullary, 103 primitive, 104 of Schwann, 104

Shivering, 211

Sight, 275

Silver nitrate as reagent, 50

skin, 204

functions of, 211

papilla of, 205

Slicle. micrometer, 280 
Suell, 269

Smootli muscles, 87

functions of, 93

in lieart, 116

Spaces, lympl-, $48,84,116$

Specialization and structure, 28, 82. See Functions and structure.

Special senses, organs of, 266

Specimens, study of, $92,183,278,281$

Siernatids, 241,245

Sipermatocytes, 241,245

Spermatogonia, $241,2+5$

sivermatozoa, 240,245

Spinal cord, 250

association-fibres of, 253

collateral fibres of, 253

gray matter of, 250

white matter of, 251

Spindle, achromatic, 38

Spirem, formation of, 36

Spirem-phase of karyokinesis, 36

Spleen, $18 t$

capsule of, 184

function of, 186

Malpighian bodies of, 186

corpuseles of, 186

pulp of, $186^{\circ}$

trabeculie of, 184

Splenic cells, 186

Spongioblasts, 249 (Fig. 232), 277

Spongioplasm, 29, 33

Squamous epithelium, 379. See Stratified epithelium.

Staining, methods of, 303

carmine, alum-, 306

borax, 307

lithio-, 307

neutral, 306

eosin, 305

fuschin, carbol-, 309

gentian-violet, 309

Crolgi's methods, 312

Gram's solution, :310

hrematoxylin, 304

iron-laxmatoxylin, 311

methylene-hlue, 308

Pal's method, 311

Unna's metlyylene-blue, 308

$V$ an Giesen's stain, 310

Stareh, tests for, 319

Stellate cells, 259

veins of kidney, 167

Stomach, 142

cardiac glands of, 144

crypts of 112

muscularis mucosæ of, 142,145

rugæe of, $1 \pm 5$

Stomata, 49

pseudo-, 49
Stratified epithelium, 56, 134, 142, 222

itratum granulosum, $206^{\circ}$

lucidum, 206;

Striated muscles, 96

Stroma of ovary, 215 of red corpuscles, 131

Stropping, method of, 239

Strumipriva, cachexia, 191

subcutaneous tissues, 83, 204

Sublingual grlands, 139

Submaxillary glands, 139

Substance, contractile, 87, 94, 96

sudoriparous glands, see S'weat-glunds.

suprarenal capsules, 194

Sustentacular cells of retina, 275 of testis, 231

Sweat-glands, 206

synchondroses, 68

Syncytium, 227

System, Haversian, 73

nervous, $109,112,248$

vascular, 114

TACTLLE corpuscles, 205, ‘66

Taste-luuds, 268

Teasing, 282

Technique, microscopical, 279

Teeth, 213

Teledendrites, 248

Teleneurites, $2+8$

Temporary cartilages, 68

Tendon, 82, 84

Terminations, nerve-, 111

Testis, 239

sustentacular cells of, 241

trabeculæ of, 240

Tests, calcium oxalate, 318

earbonates, 318

cellulose, 318

granules, albuminoid, 318

fatty, 318

hamoglobin, 318

iron, 319

phosphates, earthy, 318

stareh, 318

urates, 318

Thoracic duet, 122

Thrombus, 127

Thymus, 188,200

Thyroid body, functions of, 189,191 cartilage, 68,176

gland, 188, 189

Thyroiodin, 192

Tissue, adipose, 78 areolar, 80

development of, 80

connective, 6.5

development of, 65,78

elementary, 43 
l'ssue, elementary, recognition of, 45 (mbedding, .294

erectile, 26

tibrons, 76

rells of, 76

development of, 78

fixition of, $2 x \cdot), 290$

interstitial, 82

lymphadenoid, so

inueoid, 191

mucoms, 78

muscular, $\mathrm{si}$

cement in. $8 \mathrm{~s}$

nervons, 94

nutrition of, s1, 8.2, 114, 117

reticular, 79

Tis-ues, cardiac muscular, 89

connective, 65

elementary, 43

epithelial, 47

fixation of, $28.3,290$

jreparation of, 181

reticular, 77

sections of, 268

interpretation of, $89,183,278,281$

smooth muscular, 88

stainiug of, 308

striated muscular, 96

subcutaneous, 6:2

Tone, vascular, 98

Tongue, 137

papillæ of, 138

Tonsils, 15)2

Tollelh, 2606

Trabecula of lymph-nodes, 121

of penis, $236^{\circ}$

of spleen, 18t

of testis, 240

Trachea, 176

Tracheal cartilages, 177

Transitional epithelium, 58

Tubes. Fallonian, 220

of Heule, 163

Tubular grlands, fil

Tubule-, renal, course of, 163 lining of, 168

-miniferous, 24(1, 241

Tunica adventitia, 118, 120, I 21

alluginca, $2+0$

irranulosa, 217

intima, 118, 121

melia, 11s, 12) 1), 121

"Tunica liropria" of œiophagus, 142 vaginalis. 241

'Yyou, rrands of, 297

T IIIIILIC $1 \mathrm{~L}, \mathrm{cord}, 79$

$\mathrm{I}^{T}$ nifular nerve-cells, 103

Lnuas methylene-blue, 308
Unstriped musele, $96^{\circ}$

Urates, tests for, 318

Ureter, 17:2

lining of, is

Uretlira, $1 \%$

Urinary organs, 171

Urine, secretion of, 190

Uterus, 22:1

inuscularis mucosie of, 222

T ACUOLE $, 30,66$

contractile, 30

Tagina, 230

lining of, 5 .

Valves of heart, $11 j$

of lymplics, 115,120

of veins, 115, 119

Talvulie conniventes, 146,147

Tan Giesen's stain, 310

Tasa efferentia, 247

recta, 167,247

$\checkmark$ ascular arcades of kidney, 165 system, 114

Tas deferens, 239

Veins, 119

hepatic, 154,156

portal, 159

stellate, of kidner, 167

valves of, 115,119

Tentricles, cerebral, 22

Vermicular movement, 93

Vesicles, seminal, 28 !

Villi of intestine, 146,147

Vitreous humor of eye, 79

Tocal cords, 176

Voluntary muscle, 96 analogous to organs, 86

TWANDERING cells, 132

V Water in cytoplasm, 32

Weismann, fibres of, 99

Whartonian jelly, 79

White corpuceles, 132

fibres, 76

matter of spinal cord, 251

nerve-fibres, 102

substance of scliwann, 103

TYLOL, 314

L. methods of elearing, 314

YELLOII fibres, 77 marrow, 125

7 ENKER's fluid, 286

Jona rranulosa of adrenal body, 195)

reticularis of adrenal body, 195

\%ymogens, $45,52,140$ 




\section{PLEASE DO NOT REMOVE \\ CARDS OR SLIPS FROM THIS POCKET}

\section{UNIVERSITY OF TORONTO LIBRARY}


